Portland State University

PDXScholar

Summer 1-5-2012

\title{
Ancient Cataclysmic Floods in the Pacific Northwest: Ancestors to the Missoula Floods
}

\author{
Erica Medley \\ Portland State University
}

Follow this and additional works at: https://pdxscholar.library.pdx.edu/open_access_etds

Part of the Geology Commons, Paleontology Commons, and the Soil Science Commons Let us know how access to this document benefits you.

\section{Recommended Citation}

Medley, Erica, "Ancient Cataclysmic Floods in the Pacific Northwest: Ancestors to the Missoula Floods" (2012). Dissertations and Theses. Paper 581.

https://doi.org/10.15760/etd.581

This Thesis is brought to you for free and open access. It has been accepted for inclusion in Dissertations and Theses by an authorized administrator of PDXScholar. Please contact us if we can make this document more accessible: pdxscholar@pdx.edu. 
Ancient Cataclysmic Floods in the Pacific Northwest:

Ancestors to the Missoula Floods

by

Erica Medley

A thesis submitted in partial fulfillment of the requirements for the degree of

Master of Science

in Geology

Thesis Committee:

Scott F. Burns, Chair

Christina Hulbe

Jim O'Connor

Portland State University

(C)2012 


\section{Abstract}

Ancient Cataclysmic Floods were the Ice Age Floods that left erosional and depositional features and preceded the Missoula Floods (15-18,000 ka) in the Pacific Northwest of the United States (Allen et al., 2009). All previously studied ancient sites were visited (14) and new sites (11) were found; four Missoula Flood quarries were also visited; a total of 29 sites were studied in this thesis.

The use of calcrete paleosols to provide relative age dates for flood deposits was analyzed in this thesis. Missoula Flood gravel pits were sampled in order to examine the degree of calcrete development in flood deposits of known ages. All of the Missoula Flood deposits tested contain Stage 1 calcrete soil development.

Calcrete paleosols at sites with evidence for older floods were all analyzed. Eight sites have paleosols with Stage II development (3-12\% $\mathrm{CaCO}_{3}$ ): Rulo Outcrop, Potholes Coulee, Leslie Road, Benge, E. Callaway Road, Collier Coulee, Palouse, and Connell. Five sites have paleosols with Stage II+ development $\left(12-17 \% \mathrm{CaCO}_{3}\right)$ : Brown Road, Leslie Road, Benge, Reese Coulee, and Connell. Fourteen sites have paleosols with Stage III development (17-35\% $\left.\mathrm{CaCO}_{3}\right)$ : The Dalles, Rulo Outcrop, Winans Road 1, Poplar Heights, Yakima Bluffs, Canal Outcrop, Othello Canal, Reese Coulee, Potholes Coulee, E. Callaway Road, Frenchmen Coulee, Macall, Ritzville, and East Connell. One site has a paleosol with Stage III+ development (35-50\% $\left.\mathrm{CaCO}_{3}\right)$ : Othello Canal.

Ancient Cataclysmic flooding initiated in the Early Pleistocene, at least 1.5 Myr. Sixteen field sites show evidence for Early Pleistocene flooding, preserved in all 
six provinces: Othello Channels, Columbia River Gorge, Cheney-Palouse Scabland, Quincy Basin, Pasco Basin, and the Walla Walla Valley. There are 26 field sites with evidence for Middle Pleistocene flooding, present all regions except Othello Channels. Eleven of those 26 sites also show evidence for Early Pleistocene floods. Evidence for ancient flooding is present over dis. Evidence for Early and Middle Pleistocene floods is present over a wide distribution of elevations from 117 to 524 meters. 


\section{Acknowledgements}

I would like to thank everyone who supported me and helped me through this process in some way. I could not have finished without the help and encouragement from others.

Thanks to:

- My Mom and Dad, for supporting me not just through my thesis work but through everything leading up to that throughout my life;

- My sister, for motivating me with the things she has accomplished;

- My advisor, Scott Burns, for his inspiring enthusiasm and guidance;

- My committee members, Christina Hulbe and Jim O'Connor, whose input was extremely helpful;

- Giants that came before me, whose work was absolutely essential to this thesis: J.H. Bretz, V.R. Baker, D. Nummedal, B.N. Bjornstad, A.J. Busacca, K.R. Fecht, E.P. Kiver, M. Jaffee, P. Spencer, E.V. McDonald, R.B. Waitt, J. O'Connor;

- My field assistant and friend Kathryn Barnard, for driving all over eastern Washington with me and helping me find new field sites;

- My roommates and best friends Sarah Doliber, Skinny, and Chester, for providing lots of emotional support;

- Fellow graduate students at Portland State University, who took classes and progressed through the program with me;

- University Studies Program, for forcing me to become a public speaker and providing me with a job during this process; and the

- Avery Gravel Pit, for letting us access their property. 


\section{Table of Contents}

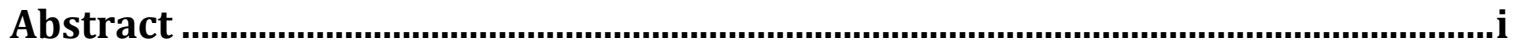

Acknowledgements .............................................................................................ii

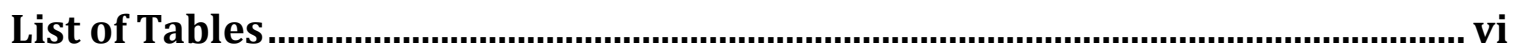

List of Figures .................................................................................................... vii

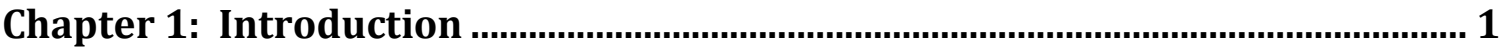

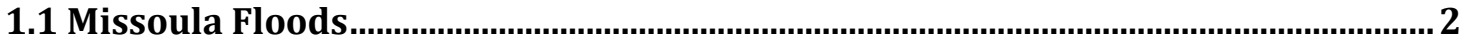

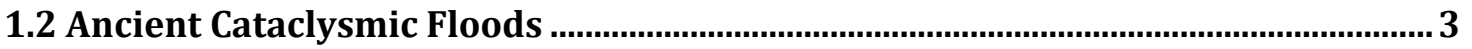

1.3 Aims and Objectives

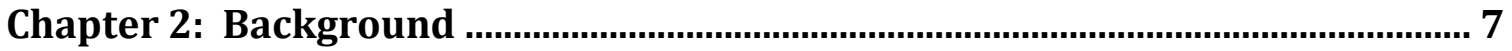

2.1 Cenozoic Geologic History of the Study Area.......................................................... 7

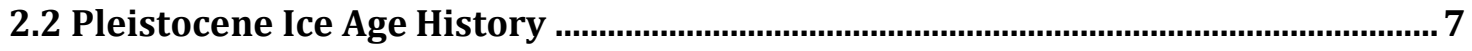

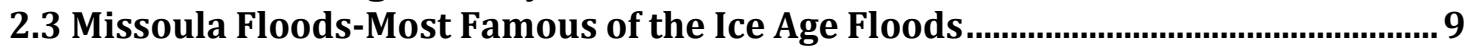

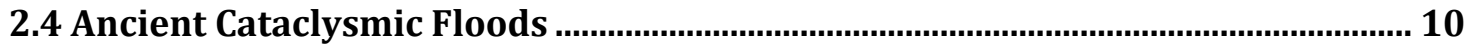

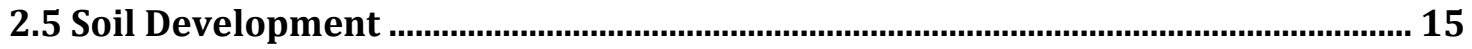

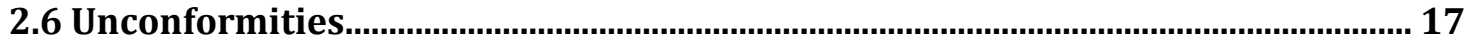

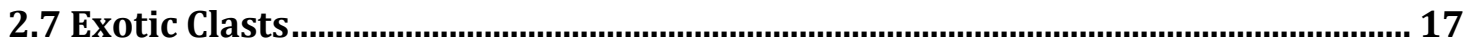

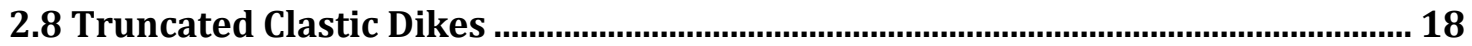

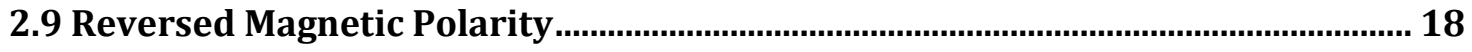

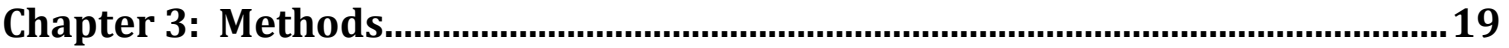

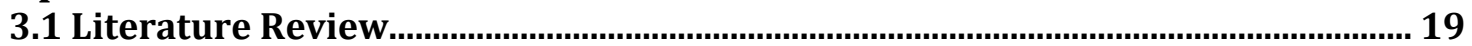

3.2 Field Data Collection .................................................................................................... 19

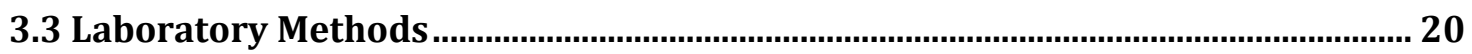

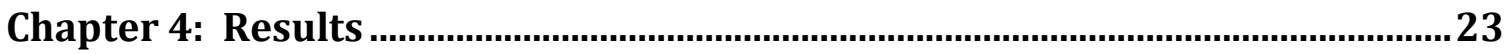

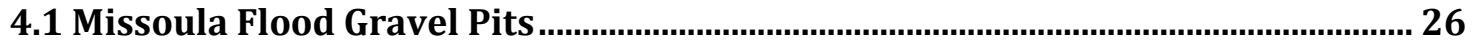

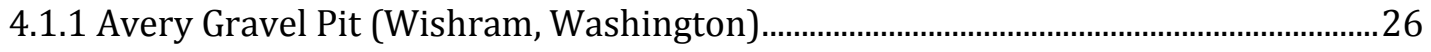

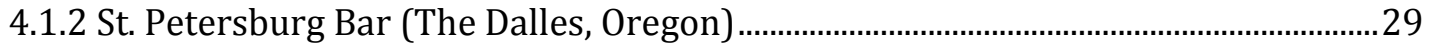

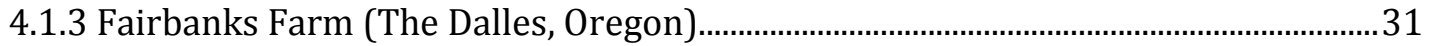

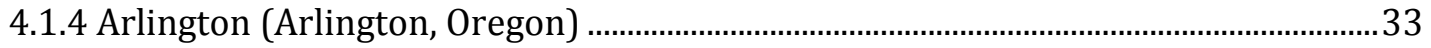

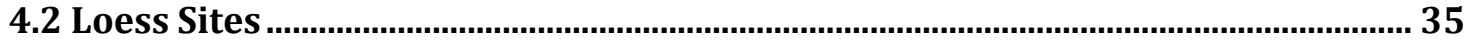

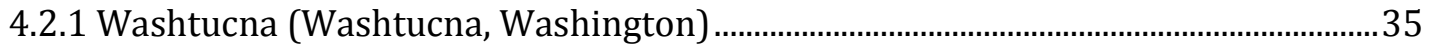

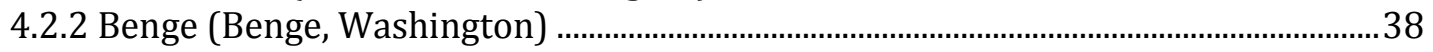

4.2.3 E. Callaway Road (Benge, Washington) ........................................................................... 41

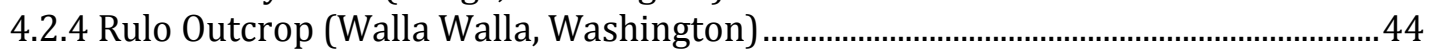

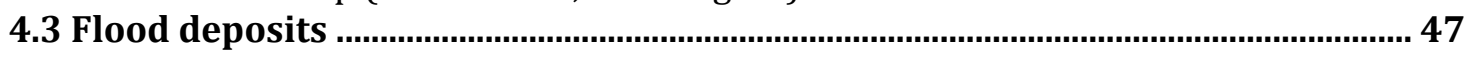

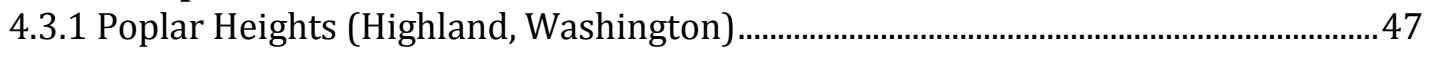

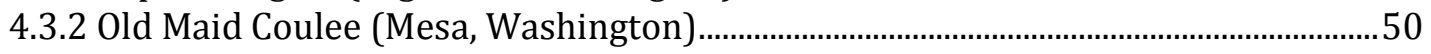

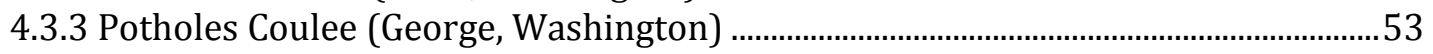

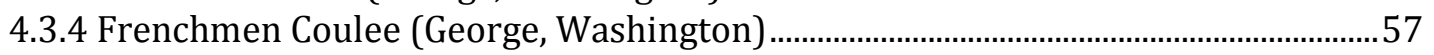

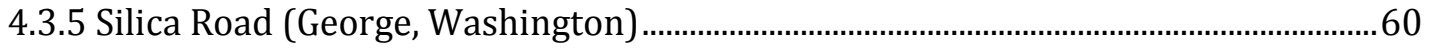

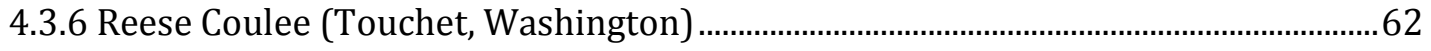

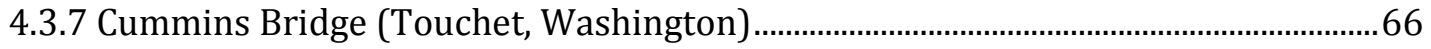

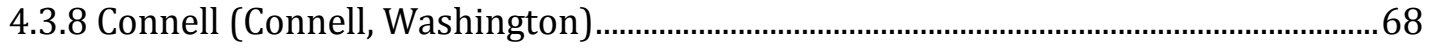

4.3.9 East Connell (Kahlotus, Washington) ……..................................................................... 70 


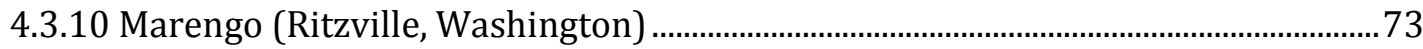

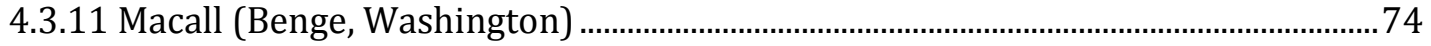

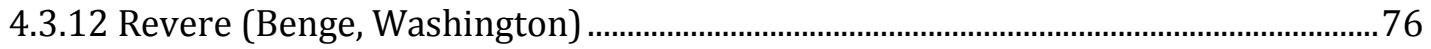

4.3.13 Leslie Road (Richland, Washington) ………................................................................ 78

4.3.14 Fuels Materials and Examination Facility (FMEF) (Richland, Washington) .........81

4.3.15 South Bombing Range Road (West Richland, Washington) ....................................... 82

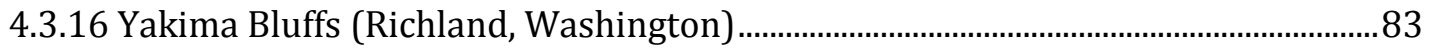

4.3.17 Field Road (Benton City, Washington) ………............................................................ 88

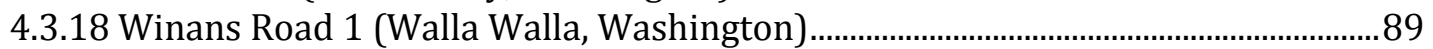

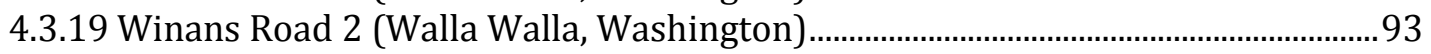

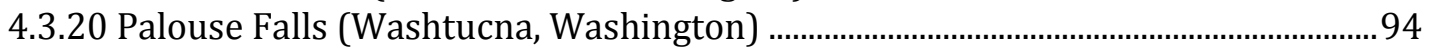

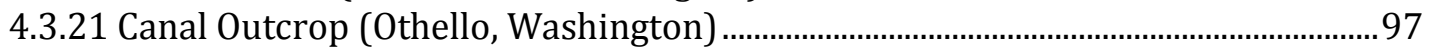

4.3.22 Othello Canal (Othello, Washington) .......................................................................... 100

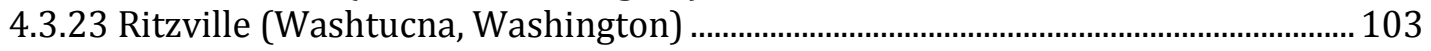

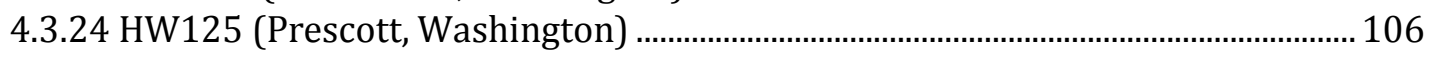

4.3.25 Brown Road (Prescott, Washington) ………........................................................... 108

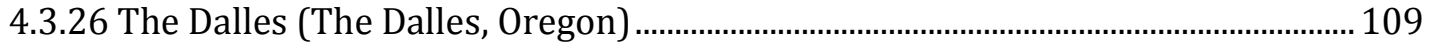

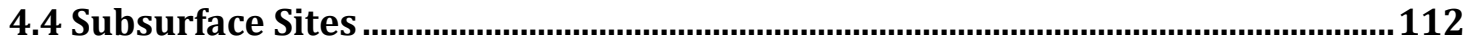

4.4.1 Cold Creek Bar (Desert Aire, Washington) ...................................................................... 112

Chapter 5: Discussion ............................................................................................... 114

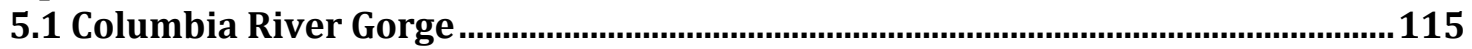

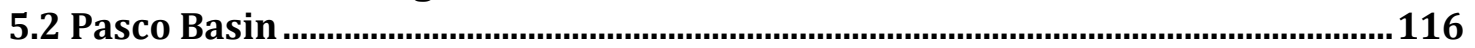

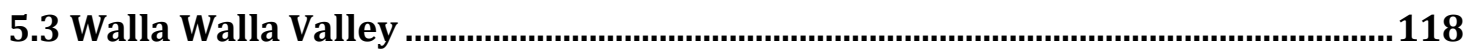

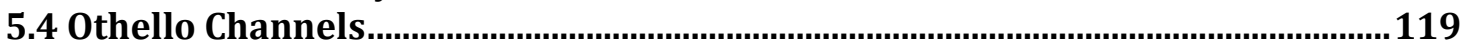

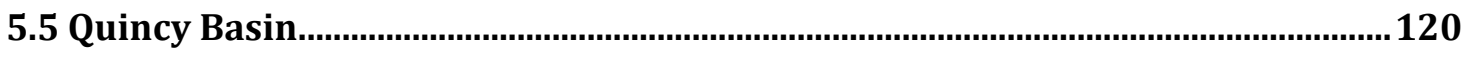

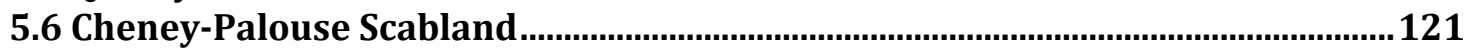

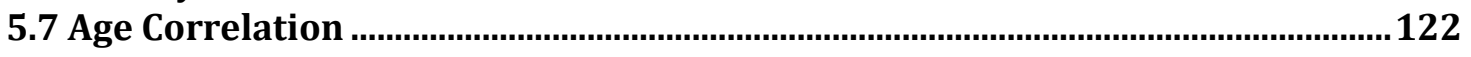

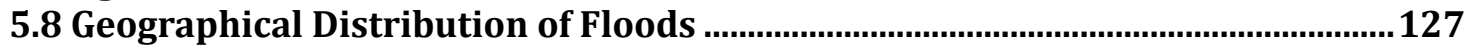

Chapter 6: Conclusions.................................................................................................. 130

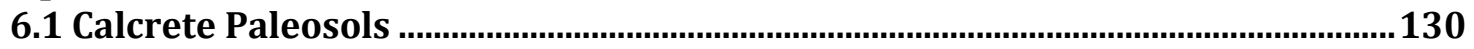

6.2 Early Pleistocene deposits .................................................................................. 131

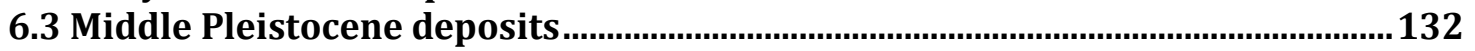

6.4 Calcrete formation in Missoula Flood gravel deposits in quarries .......................133

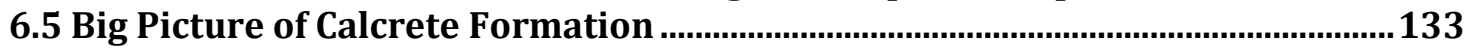

6.6 Particle size grading curve for a loess vs. flood deposit.......................................135

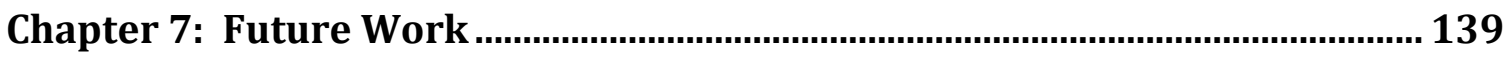

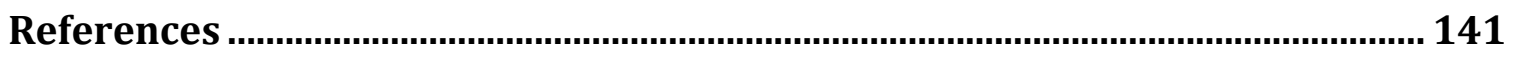

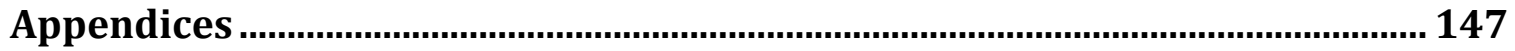

Appendix A: $\mathrm{CaCO}_{3}$ analysis, Chittick methods ......................................................147

Appendix B: Grain size analysis, pipette methods.....................................................

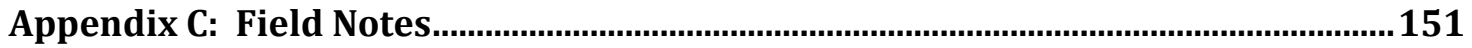




\section{List of Tables}

Table 1 Stages of carbonate morphology (modified from Machette (1985)).............. 21

Table 2 Complete list of field sites from west to east with GPS location, elevation,

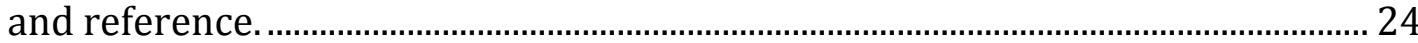

Table 3 Chittick results for Avery Gravel Pit site. …………………………………... 29

Table 4 Chittick results for St. Petersburg Bar site......................................................... 31

Table 5 Chittick results for Fairbanks Farm site. ............................................................. 33

Table 6 Chittick results for Arlington site..................................................................... 34

Table 7 Chittick results for Washtucna field site.............................................................. 38

Table 8 Chittick results for Benge site............................................................................... 41

Table 9 Chittick results for E. Callaway Road site............................................................. 43

Table 10 Chittick results for Rulo Outcrop site................................................................ 46

Table 11 Chittick results for Poplar Heights site............................................................ 50

Table 12 Chittick results for Old Maid Coulee site........................................................... 53

Table 13 Chittick results for Potholes Coulee site. …………………………………..... 56

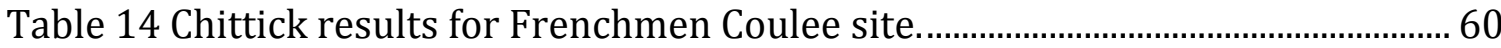

Table 15 Chittick results for Reese Coulee site...............................................................65

Table 16 Chittick results for Connell site. .................................................................... 70

Table 17 Chittick results for East Connell site................................................................. 72

Table 18 Chittick results for Macall site........................................................................... 75

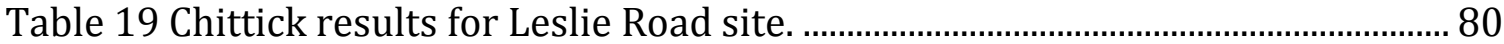

Table 20 Chittick results for Yakima Bluffs site............................................................... 87

Table 21 Chittick results for Field Rdoad site................................................................ 89

Table 22 Chittick results for Winans Road 1 site. .......................................................... 92

Table 23 Chittick results for Palouse Falls site. ............................................................. 97

Table 24 Chittick results for Canal Outcrop site.............................................................. 99

Table 25 Chittick results for Othello Canal site...............................................................103

Table 26 Chittick results for Ritzville site. ……………………………………….......106

Table 27 Chittick results for Brown Road site..............................................................109

Table 28 Chittick results for The Dalles site, samples OR1-OR5 were sampled and analyzed by me; Loess-Paleosol 5 were sampled and analyzed by Cordero (1997).

Table 29 Field sites with evidence for flooding throughout the Pleistocene. If more than one event is displayed at the site, the number is in parentheses. The highlighted sites have evidence for both Early and Middle Pleistocene floods.

Table 30 Particle size results of a slackwater deposit (OC1) and a loess deposit (WCC1).

Table 31 Summary of elevation and calcrete development for each field site. .........136 


\section{List of Figures}

Figure 1 The Ice Age Floods National Geologic Trail. (Ice Age Flood Institute, 2011) 1 Figure 2. Glacial Lake Missoula (blue) and the extent of the Missoula Floods (gray).

(Parfit, 1995)

Figure 3 Deep sea curve showing Oxygen Isotope Stage and Magnetic Polarity, July

temperatures based on pollen analysis (Berendsen 2004).

Figure 4 Cordilleran Ice Sheet with three lobes (DeGrey and Link, 1999). 8

Figure 5 Overview map of Washington and Oregon with field sites of Ancient

Cataclysmic Flood deposits represented as yellow squares. The red square shows the location of Figure 6.

Figure 6 Eastern Washington and Oregon with field sites labeled. 12

Figure 7 Stages of carbonate morphology for gravelly parent material on top and

fine-grained soil on the bottom (Birkeland, 1999; based on Gile et al., 1981)... 15

Figure 8 Stages of Carbonate Morphology. Taken from Birkeland (1999). (Gile et al.,

1981; modification by R.R. Shroba, 1982; Machette, 1985) ................................... 16

Figure 9 Chittick apparatus. ......................................................................................... 20

Figure 10 Location of the Avery Gravel Pit field site. ..................................................... 26

Figure 11 Overview of Avery Gravel Pit showing the lower and upper section

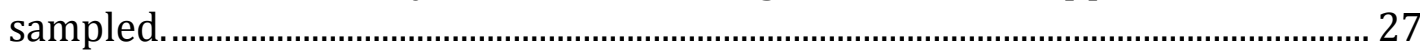

Figure 12 Lower flood gravel section at Avery Gravel Pit with sample locations

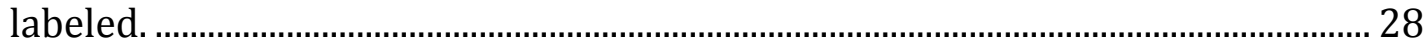

Figure 13 Upper flood gravel section at Avery Gravel Pit with sample locations

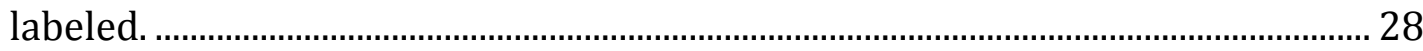

Figure 14 Location of the St. Petersburg Bar field site................................................... 29

Figure 15 West end of St. Petersburg Bar gravel pit with sample locations labeled. 30 Figure 16 East end of St. Petersburg Bar gravel pit with sample location labeled.... 30 Figure 17 Location of the Fairbanks Farm field site near The Dalles, Oregon............. 32

Figure 18 Fairbanks Farm outcrop with sample locations labeled................................. 32

Figure 19 Location of the Arlington field site................................................................... 33

Figure 20 Arlington roadcut with sample location labeled............................................. 34

Figure 21 Location of the Washtucna field site near Washtucna, Washington........... 35

Figure 22 Washtucna outcrop with sample locations labeled......................................... 36

Figure 23 Washtucna stratigraphy, "Line-and stipple pattern marks approximate position of prominent paleosol B horizons. Dashed lines are tephras; those correlated are : M=Mazama; MSH S=Mount St. Helens set S; MSH C= Mount St. Helens set C. Heavy lines are flood-cut unconformities and are labeled alphabetically" (McDonald and Busacca, 1988a).......................................................... 36

Figure 24 Location of the Benge field site...................................................................... 38

Figure 25 Benge Outcrop with sample locations labeled B1-B5................................... 39

Figure 26 Benge stratigraphy, "Line-and stipple pattern marks approximate position of prominent paleosol B horizons. Dashed lines are tephras; those correlated are : M=Mazama; MSH S=Mount St. Helens set S; MSH C= Mount St. Helens set C. Heavy lines are flood-cut unconformities and are labeled alphabetically" (McDonald and Busacca, 1988a)............................................................................ 40 
Figure 27 Location of the E. Callaway Road field site near Benge, Washington......... 41 Figure 28 E. Callaway Road outcrop, the red box indicates the location of Error!

Reference source not found.................................................................................... 42

Figure 29 E. Callaway Road close-up with sample locations labeled.............................. 42

Figure 30 Stratigraphy of E. Callaway Road outcrop..................................................... 43

Figure 31 Location of the Rulo Outcrop field site near Walla Walla, Washington. .... 44

Figure 32 Rulo outcrop with sample locations labeled, red lines are unconformities

and the yellow line is a clastic dike. ………………………................................... 45

Figure 33 Location of Poplar Heights field site in Highland, Washington..................... 47

Figure 34 Poplar Heights outcrop with sample locations labeled................................... 48

Figure 35 Stratigraphy of Poplar Heights outcrop. …………………………………..... 49

Figure 36 Close-up on exotic clasts present in the gravel-dominated PH1 flood

deposit at Poplar Heights.......................................................................................... 49

Figure 37 Location of Old Maid Coulee field site near Mesa, Washington. ................... 50

Figure 38 Old Maid Coulee outcrop................................................................................ 51

Figure 39 Old Maid Coulee outcrop with sample locations labeled................................ 52

Figure 40 Location of Potholes Coulee field site, north of George, Washington......... 53

Figure 41 Potholes Coulee outcrop with sample locations labeled.............................. 54

Figure 42 Highly weathered basalt clast (sample PC5) found in layer PC4 at Potholes

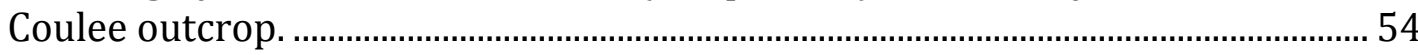

Figure 43 Stratigraphy of Potholes Coulee outcrop........................................................ 55

Figure 44 Location of the Frenchmen Coulee field site near George, Washington.... 57

Figure 45 Frenchmen Coulee outcrop with sample locations labeled........................... 58

Figure 46 Stratigraphy of Frenchmen Coulee outcrop.................................................... 59

Figure 47 Close-up of the contact between weathered basalt bedrock and calcrete

paleosol at Frenchmen Coulee. ............................................................................ 59

Figure 48 Location of the Silica Road field sites near George, Washington................... 60

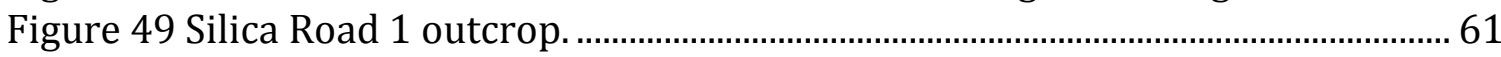

Figure 50 Silica Road 2 outcrop................................................................................ 62

Figure 51 Location of the Reese Coulee field site, west of Wallula, Washington........ 62

Figure 52 Reese Coulee outcrop with sample locations labeled. Photo by Kat

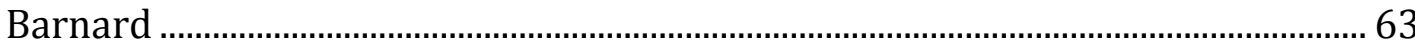

Figure 53 Basalt boulder covered in calcrete, sample locations labeled.........................64

Figure 54 Clastic silt dike at Reese Coulee outcrop. Photo Kat Barnard ......................... 64

Figure 55 Location of the Cummins Bridge field site near Touchet, Washington...... 66

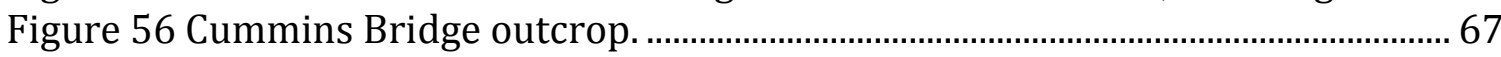

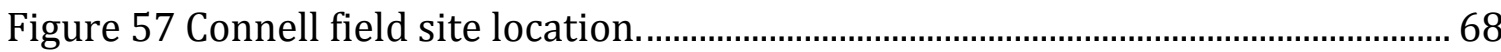

Figure 58 Connell outcrop with sample locations labeled. ............................................... 69

Figure 59 Location of the East Connell field site, west of Kahlotus, Washington....... 70

Figure 60 East Connell field site with sample locations labeled. ...................................... 71

Figure 61 Stratigraphy of East Connell outcrop. .............................................................. 72

Figure 62 Location of the Marengo field site near Ritzville, Washington...................... 73

Figure 63 Marengo railroad cut. Only weathered basalt was found here..................... 73

Figure 64 Location of the Macall field site, northwest of Benge, Washington.............. 74

Figure 65 Macall outcrop with sample location labeled..................................................... 75

viii 
Figure 66 Location of the Revere field site near Benge, Washington.............................. 76

Figure 67 Revere outcrop with sample locations labels. .................................................. 77

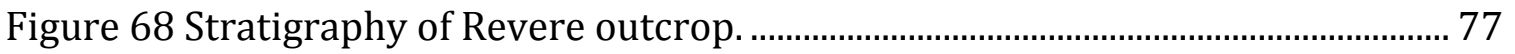

Figure 69 Location of the Leslie Road field site, near Richland, Washington............. 78

Figure 70 Leslie Road outcrop with sample locations labeled. ....................................... 79

Figure 71 Stratigraphy at Leslie Road outcrop................................................................. 79

Figure 72 Exotic clasts from the gravelly flood deposit LR2 at Leslie Road outcrop.80

Figure 73 Location of the FMEF field site, north of Richland, Washington................... 81

Figure 74 Location of the South Bombing Range Road field site.................................... 82

Figure 75 Location of the Yakima Bluffs field site near Richland, Washington........... 83

Figure 76 Yakima Bluffs outcrop, upper gravels; sample locations labeled................. 84

Figure 77 Exotic clasts in the gravel-dominated flood deposits at Yakima Bluffs

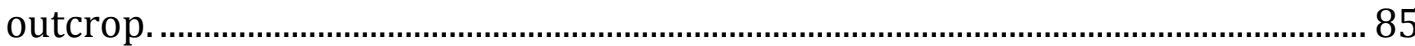

Figure 78 Unconformable contact between flood gravels and slackwater rhythmites

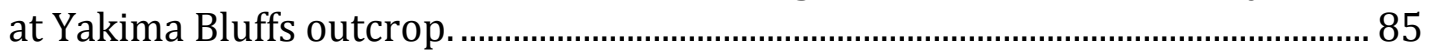

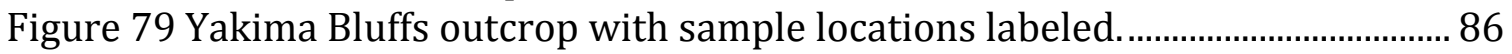

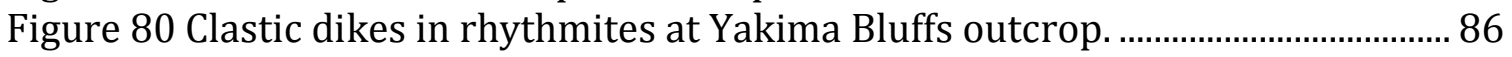

Figure 81 Location of the Field Road field site near Benton City, Washington.......... 88

Figure 82 Field Road outcrop with sample locations labeled........................................ 88

Figure 83 Location of the Winans Road 1 field site near Walla Walla, Washington.. 90

Figure 84 Winans Road 1 outcrop with sample locations labeled................................. 91

Figure 85 Stratigraphy of Winans Road 1 outcrop.............................................................. 92

Figure 86 Location of the Winans Road 2 field site............................................................... 93

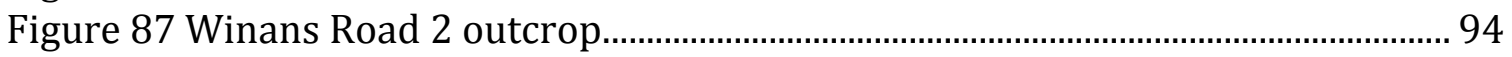

Figure 88 Location of the Palouse Falls field site.......................................................... 95

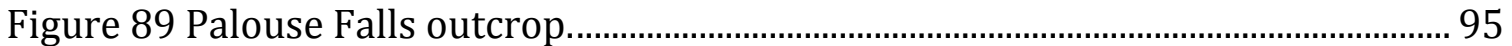

Figure 90 Palouse Falls outcrop with sample locations labeled. ....................................96

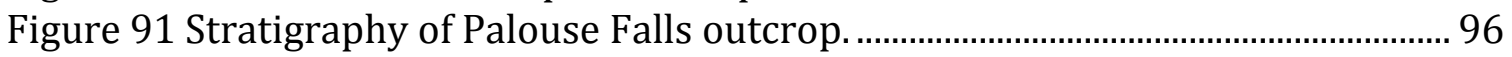

Figure 92 Location of the Canal Outcrop field site............................................................ 97

Figure 93 Canal Outcrop with sample locations labeled. Photograph by Kathryn

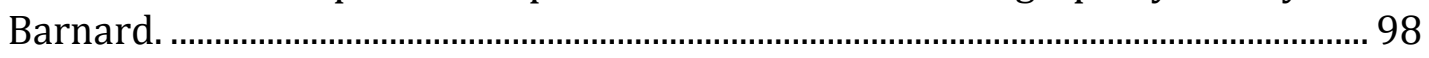

Figure 94 Stratigraphy of Canal Outcrop............................................................................... 99

Figure 95 Location of the Othello Canal field site, southeast of Othello, Washington.

100

Figure 96 Othello Canal outcrop with sample locations labeled....................................101

Figure 97 Othello Canal close-up with sample locations labeled...................................101

Figure 98 Stratigraphy of Othello Canal outcrop.

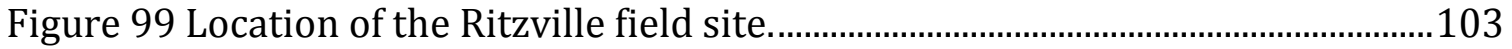

Figure 100 Ritzville field sites, described by McDonald and Busacca (1988a).

Samples were not collected from this outcrop but correlate to the adjacent

section that was sampled. Photograph by Kathryn Barnard.

Figure 101 HW260 Field site adjacent to the Ritzville site, samples collected in

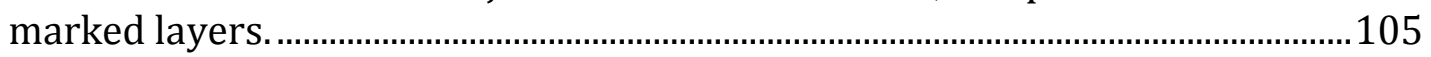

Figure 102 Stratigraphy of HW260 outcrop. .................................................................. 105

Figure 103 Location of the HW125 field site near Prescott, Washington. ..................107 


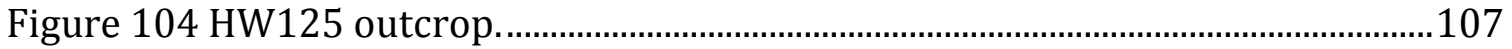

Figure 105 Location of the Brown Road field site near Prescott, Washington..........108

Figure 106 Brown Road outcrop with sample locations labeled..................................108

Figure 107 Location of The Dalles field site near The Dalles, Oregon...........................110

Figure 108 The Dalles outcrop with sample locations labeled; samples P1-P5 correlate to Cordero (1997). Yellow line is a reverse fault...................................111

Figure 109 Schematic of The Dalles field site with sample locations labeled (Cordero, 1997)

Figure 110 Location of the Cold Creek Bar field site....................................................113

Figure 111 Overview of field sites with geographical zones colored: Columbia River Gorge (blue), Pasco Basin (teal), Walla Walla Valley (green), Othello Channels (fuchsia), Quincy Basin (red), and Cheney-Palouse (yellow).

Figure 112 The Columbia River Gorge region with field sites labeled. ........................115

Figure 113 The Pasco Basin region with field sites labeled..........................................116

Figure 114 The Walla Walla Valley region with field sites labeled...............................118

Figure 115 The Othello Channels region with field sites labeled. .................................119

Figure 116 The Quincy Basin region with field sites labeled. ......................................120

Figure 117 The Cheney-Palouse region with field sites labeled. ..................................121

Figure 118 Field sites with evidence for Early Pleistocene flooding are in red and all other sites are yellow. ........................................................................................125

Figure 119 Field sites with evidence for Middle Pleistocene flooding are in aqua and all other sites are yellow........................................................................................126

Figure 120 Graph showing elevations flood deposits of different ages, the triangles represent field sites. 


\section{Chapter 1: Introduction}

The Ice Age Floods include all the floods occurring in the Pleistocene; the Missoula Floods from 15 - $18 \mathrm{ka}$ and the Ancient Cataclysmic Floods from 2.6 Ma to $18 \mathrm{ka}$. The Missoula Floods are well studied but there is a need to put together all of the information available about the Ancient Cataclysmic Floods. The National Park Service has recognized the importance of the Ice Age Floods and has proposed that the Ice Age Floods National Geologic Trail be established (Figure 1). It formally became a national park in 2011 (Ice Age Flood Institute, 2011). The trail is "the largest, most systematic, and most cooperative effort yet proposed to bring the dramatic story of the Ice Age Floods to the public's attention, and this has the potential to bring significant economic and cultural benefits to communities throughout the Northwest" (Ice Age Flood Institute, 2011).

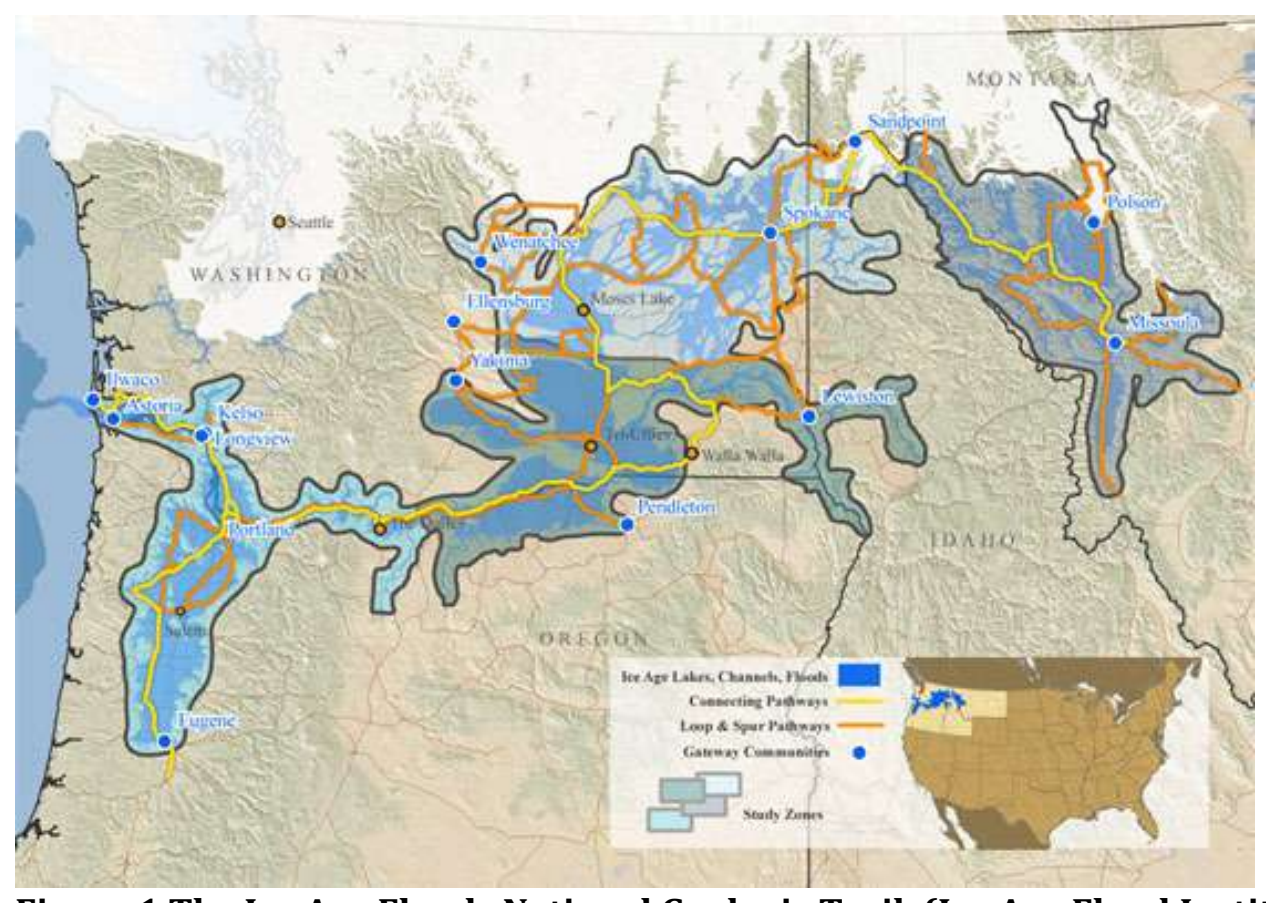

Figure 1 The Ice Age Floods National Geologic Trail. (Ice Age Flood Institute, 2011) 
The Missoula Floods have been the main focus of the trail and the most studied floods. However, researchers on the Missoula Floods all mention bits and pieces of evidence for older flood events. No one has put together the complete story of these Ancient Cataclysmic Floods (Allen et al., 2009).

\subsection{Missoula Floods}

The Missoula Floods were one of the greatest sets of geologic events in Earth's recent history. The floods lasted 3,000 years from 15 to 18 thousand calendar years ago (Allen et al., 2009). J Harlen Bretz $(1923 ; 1928)$ was the first to propose that flooding created the channeled scablands in eastern Washington and Oregon. In 1980, Waitt described rhythmites near Touchet, Washington to propose multiple flooding episodes rather than one large flood. He estimated 40 floods by counting rhythmite sequences; Atwater (1984) expanded that number to about 89 floods in the 3,000-year period. Forty of the floods reached the Wallula Gap and Portland (Waitt, 1980).

The Missoula Floods affected 41,440 square kilometers in Washington and Oregon (Allen et al., 2009). The floods initiated at the end of the last ice age when an ice dam filled the Pend Oreille Valley and blocked the Clark Fork River from flowing from western Montana into the Columbia River Basin. Flows from Glacial Lake Missoula when the ice dam broke had estimated velocities up to 27.4 meters per second (Baker et al., 1991). Eventually, the ice dam reformed and Glacial Lake Missoula was created again until the next ice dam breached (Baker et al., 1991). Layers of loess, animal burrows, and Mt. St. Helens tephra in between layers of 
rhythmite flood deposits provide the evidence for the draining of Glacial Lake Missoula in between flooding events (Waitt, 1980). The catastrophically large floods left a lot of evidence behind in the form of erosional and depositional features (Figure 1) in the Channeled Scablands of eastern Washington.

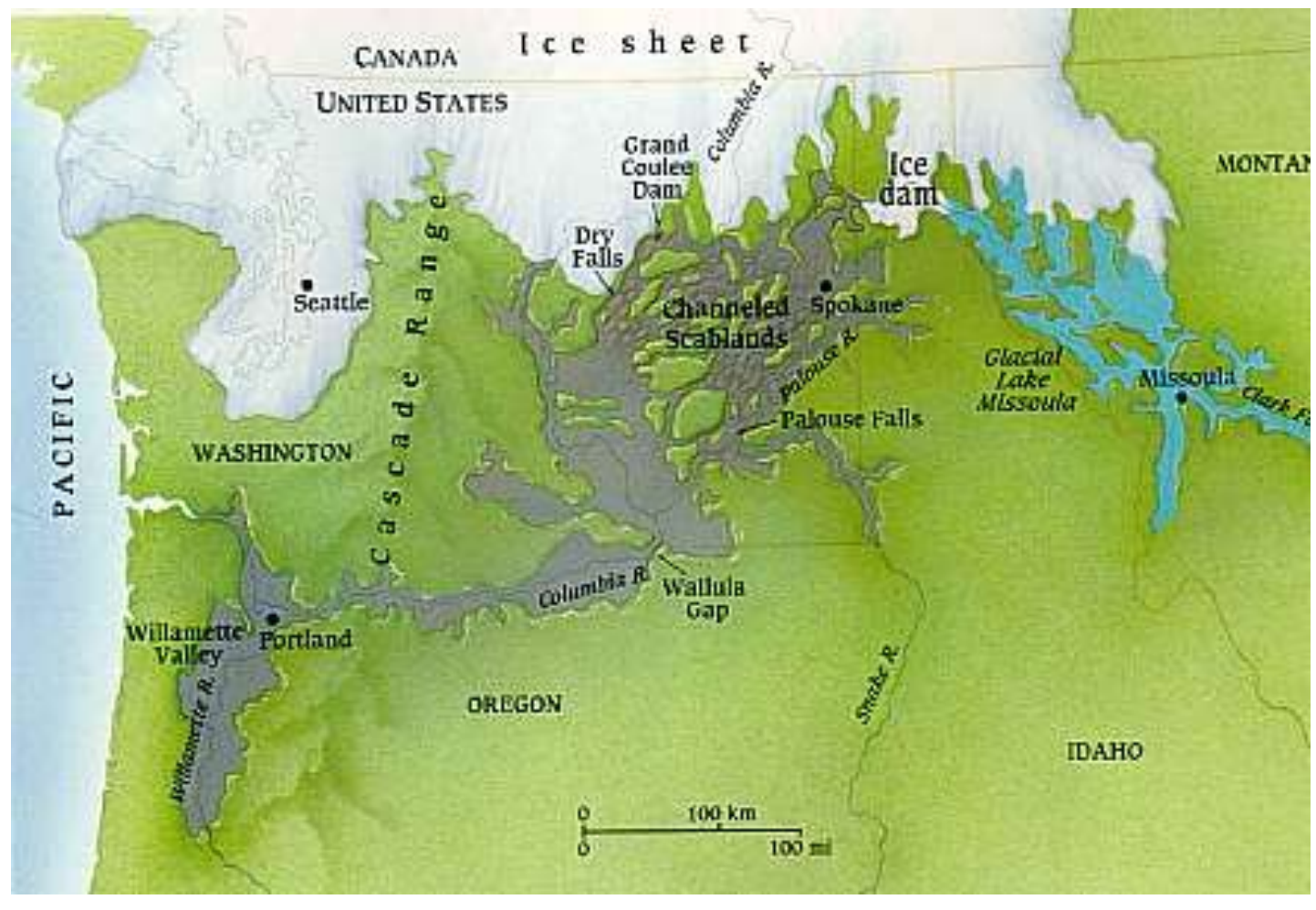

Figure 2. Glacial Lake Missoula (blue) and the extent of the Missoula Floods (gray). (Parfit, 1995)

\subsection{Ancient Cataclysmic Floods}

The Missoula Floods eroded away much of the evidence of older flooding that may have occurred before the first Missoula Flood 18,000 calendar years ago. However, many geologists who have studied the Missoula Floods have documented evidence of much older flood deposits at certain localities in the channeled scablands of Eastern Washington and Oregon. These old floods, termed the Ancient 
Cataclysmic Floods by Allen et al. (2009), are thought to have occurred throughout the Quaternary.

There are several criteria used for determining if a flood is older than the Missoula Floods. One method is by dating organic material present in flood deposits that produces dates $>18,000$ years B.P. and shows a clear stratigraphic relationship to the "younger" Missoula Flood deposits and paleosols. Geologists have also found evidence of magnetic reversals in paleosols and older flood deposits (Bjornstad, 2006). The last magnetic reversal was 790,000 years before present (Johnson, 1982); therefore, those deposits are much older in age than the Missoula Floods. Another criteria for distinguishing the Ancient Cataclysmic Floods from the Missoula Floods is by determining the stage of calcrete development in the soils developed on the flood deposits. Stages I through IV of $\mathrm{CaCO}_{3}$ development take certain amounts of time (Birkeland, 1999). "In most cases Stages II, III, and IV carbonate take more time to develop than possible since the last Missoula Flood 15,000 years ago" (Allen et al., 2009). Exotic clasts may also be used as indicators of Ancient Cataclysmic Floods, especially when used in conjunction with other criteria. The Columbia Plateau is composed of thick basalt sequences; therefore, any nonbasalt clasts found in a deposit imply that the deposit has been transported from a different source.

\subsection{Aims and Objectives}

There are many known Missoula Flood deposits in the Channeled Scablands of Eastern Washington and Oregon. There is stratigraphic evidence at certain 
localities for floods that are older. My objectives are to determine where the Ancient Cataclysmic Flood deposits are located, how widely distributed they are, and how many separate flood events there were that preceded the Missoula Floods.

1. A complete literature review of every paper that cites evidence of Ancient Cataclysmic Flood deposits.

2. Visit all the sites mentioned in literature. At each site, do the following:
a. Take photos,
b. Record GPS location and elevation,
c. Take samples of flood deposits and calcrete paleosols, and
d. Analyze the stratigraphy.

3. Find new sites with evidence of Ancient Cataclysmic Flood deposits. Evidence of these sites exhibit:
a. Significant calcrete development,
b. Flood gravels with exotic clasts, and/or
c. Rhythmites with calcrete layers above them.

4. Collect samples of Missoula Flood deposits at gravel pits and quarries that are younger than Ancient Cataclysmic Flood deposits.

5. Lab work on sediment samples:
a. Percentage of $\mathrm{CaCO}_{3}$,
b. Stage of $\mathrm{CaCO}_{3}$ development, and
c. Particle size and color in some cases. 
6. Develop chronosequence for Missoula Floods and Ancient Cataclysmic Floods.

7. Compare all sites in study through chronosequences and geographic positions and determine relationships 


\section{Chapter 2: Background}

\subsection{Cenozoic Geologic History of the Study Area}

The main bedrock across eastern Washington and Oregon is Columbia River Basalt (CRB). CRB was formed during the Miocene 17-6 Ma from lava that flowed from vents on the eastern edge of Washington and Oregon. The Imnaha and Grande Ronde Formations make up 90 percent of the CRB, and flowed/cooled from 16.6 to $15 \mathrm{Ma}$ (Reidel and Hooper, 1989). Some sedimentation happened concurrently with the basalt flows; the Ellensburg Formation is composed of silt, sand, and graded lahar beds several meters thick interbedded with basalt flows at the eastern edge of the Cascade Mountains (Carson and Pogue, 1996).

The Palouse Formation, deposited throughout the Pleistocene, is extensive in eastern Washington, especially in the Pasco Basin near the tri-cities of Richland, Pasco, and Kennewick. The Palouse Formation is composed of blankets of loess and paleosols formed during times of intermittent deposition.

\subsection{Pleistocene Ice Age History}

Glacial advances and retreats are important for sediment supply. Interglacial stages represent a time of abundant sediment supply and rapid loess deposition; whereas, glacial maximums are a time of relatively stable soil development (Smiley et al., 1991). The series of glacial advances and retreats began at the beginning of the Pleistocene 2.6 Ma and lasted until 10,000 years ago. Four major advances were originally recognized on land in North America: the Nebraskan 2 to $1.65 \mathrm{Ma}$, Kansan 
900 to $750 \mathrm{ka}$, Illinoisan 400 to $250 \mathrm{ka}$, and most recently the Wisconsinan from 100 to 11 ka (Smiley et al., 1991).

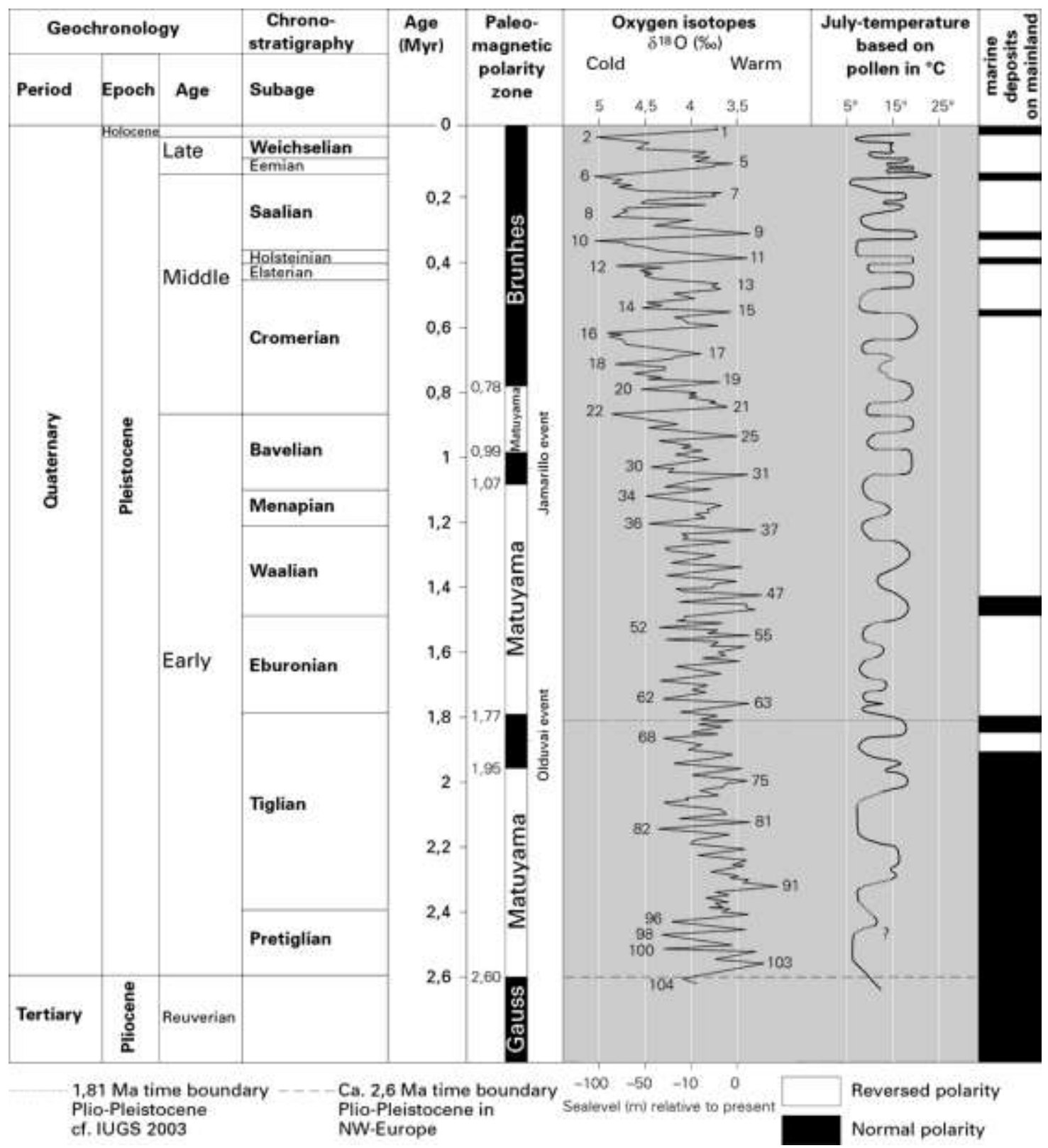

Figure 3 Deep sea curve showing Oxygen Isotope Stage and Magnetic Polarity, July temperatures based on pollen analysis (Berendsen 2004).

Based on the deep-sea curve (Figure 3) there probably were actually over 50 advances and retreats, and there could be as many as 44 interglacial cycles in the Pleistocene (Morrison, 1991). 
It is difficult to estimate the number of ice age floods in eastern Washington because of the unknown amounts of erosion between cycles, and perhaps only the largest advances resulted in flooding. The number of ice age floods could be in the hundreds. The Cordilleran Ice Sheet had three lobes that extended southward from Canada into Washington, Idaho and Montana (DeGrey and Link, 1999). The three lobes from west to east were the Puget, Okanogan, and Purcell (Figure 4).

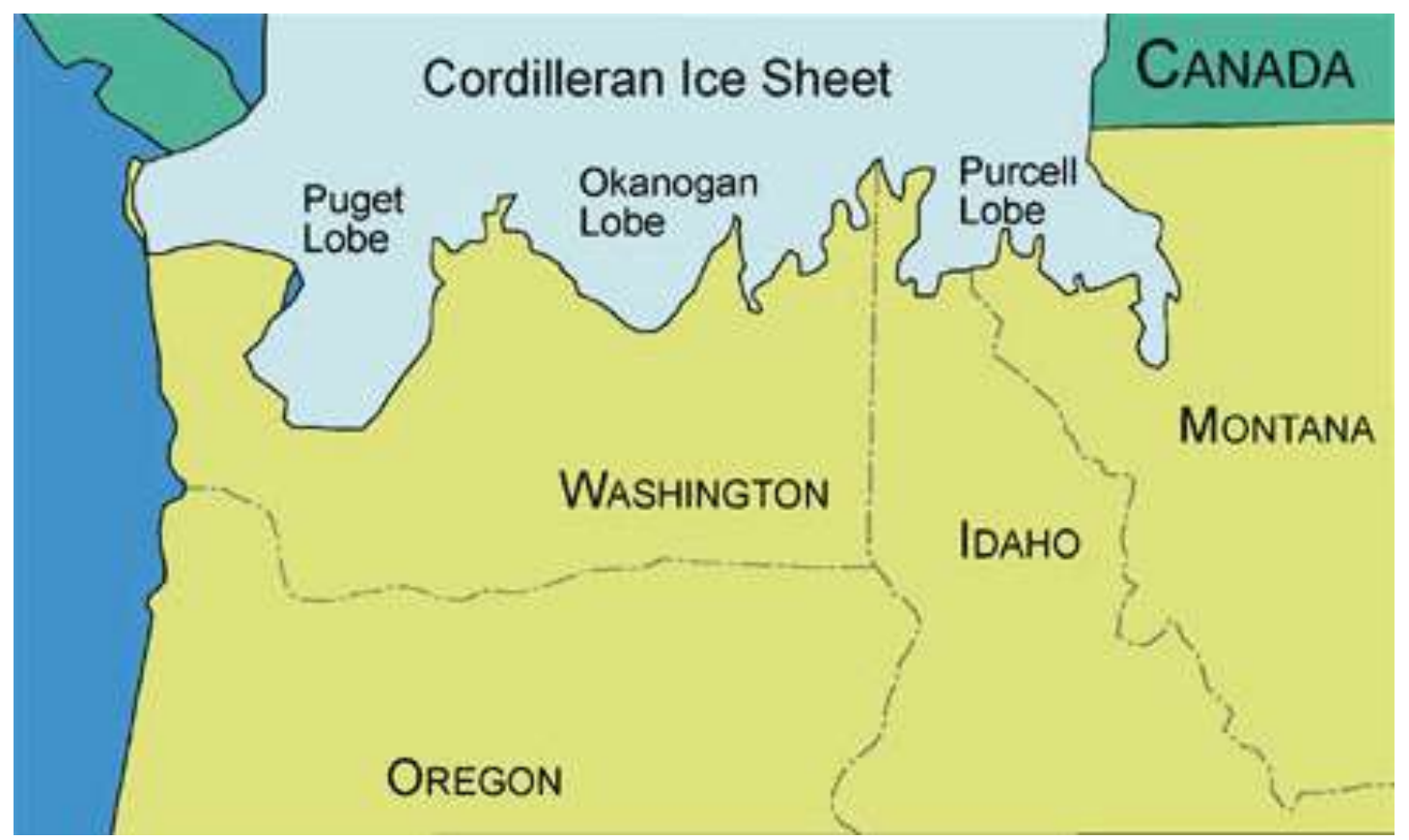

Figure 4 Cordilleran Ice Sheet with three lobes (DeGrey and Link, 1999).

\subsection{Missoula Floods-Most Famous of the Ice Age Floods}

The Missoula Floods occurred during the late-Wisconsin glaciation, 15-18ka in calendar years (Allen et al., 2009). Bretz $(1923,1928)$ was the first to recognize that a flood had created the depositional and erosional features in the Channeled Scablands and termed it the "Spokane Flood." In 1961, Bretz modified the flood title to "Missoula Flood." Baker (1973) made quantitative descriptions of the Missoula 
Flood. Waitt (1980) used rhythmite sequences to propose a multiple flood hypothesis, estimating 40 floods. In 1984, Atwater expanded that number to 89 floods in the 3,000 year period.

"Preceding the Wisconsin glaciation, mostly interglacial conditions existed for $\sim 50,000$ years during the Sangamon (80-130 ka) (oxygen isotope stage 5)" (Bjornstad et al., 2001). According to Clague et al. (1980), Glacial Lake Missoula could only have existed between 18.9 to 14 ka based on radiocarbon dating and estimates of the length of time the Purcell lobe of the Cordilleran Ice Sheet would take to advance. Clague et al. (1980) also used lake varves that indicate it was only in existence for 2,500 years.

The pre-late Wisconsin Ancient Cataclysmic Floods occurred throughout the Pleistocene, approximately the last 2.6 Ma. Glacial Lake Missoula formed behind an ice dam from a finger of the Purcell Lobe. It is possible that the Ancient Cataclysmic Floods had sources in addition to ancient Glacial Lake Missoula, which could have included the ice-damned lakes from the Okanogan and Purcell lobes of the Cordilleran Ice Sheet (Figure 4) (Allen et al., 2009; Shaw et al., 1999).

\subsection{Ancient Cataclysmic Floods}

Several authors cite evidence for flooding episodes prior to the Missoula Floods (Figure 5, 6), called the "Ancient Cataclysmic Floods" by Allen et al. (2009). Most of these Ancient Cataclysmic Flood deposits have been eroded away by the powerful subsequent Missoula Floods. However, evidence exists at certain localities referenced by geologists who studied the scablands. Baker and Nummedal (1978) 
found successions of coarse-grained flood gravels, fine-grained flood sediments, and loess overlain by paleosols near Marengo, Washington. Three of the loess units are overlain by calcareous paleosols, which could not have developed in 18,000 years. Baker and Nummedal (1978) correlated the gravels at Marengo to other exposures at Revere, Macall, and Old Maid Coulee. Old Maid Coulee was also shown by Bjornstad (2006) as having reversed magnetic polarity, an age of at least $790 \mathrm{ka}$.

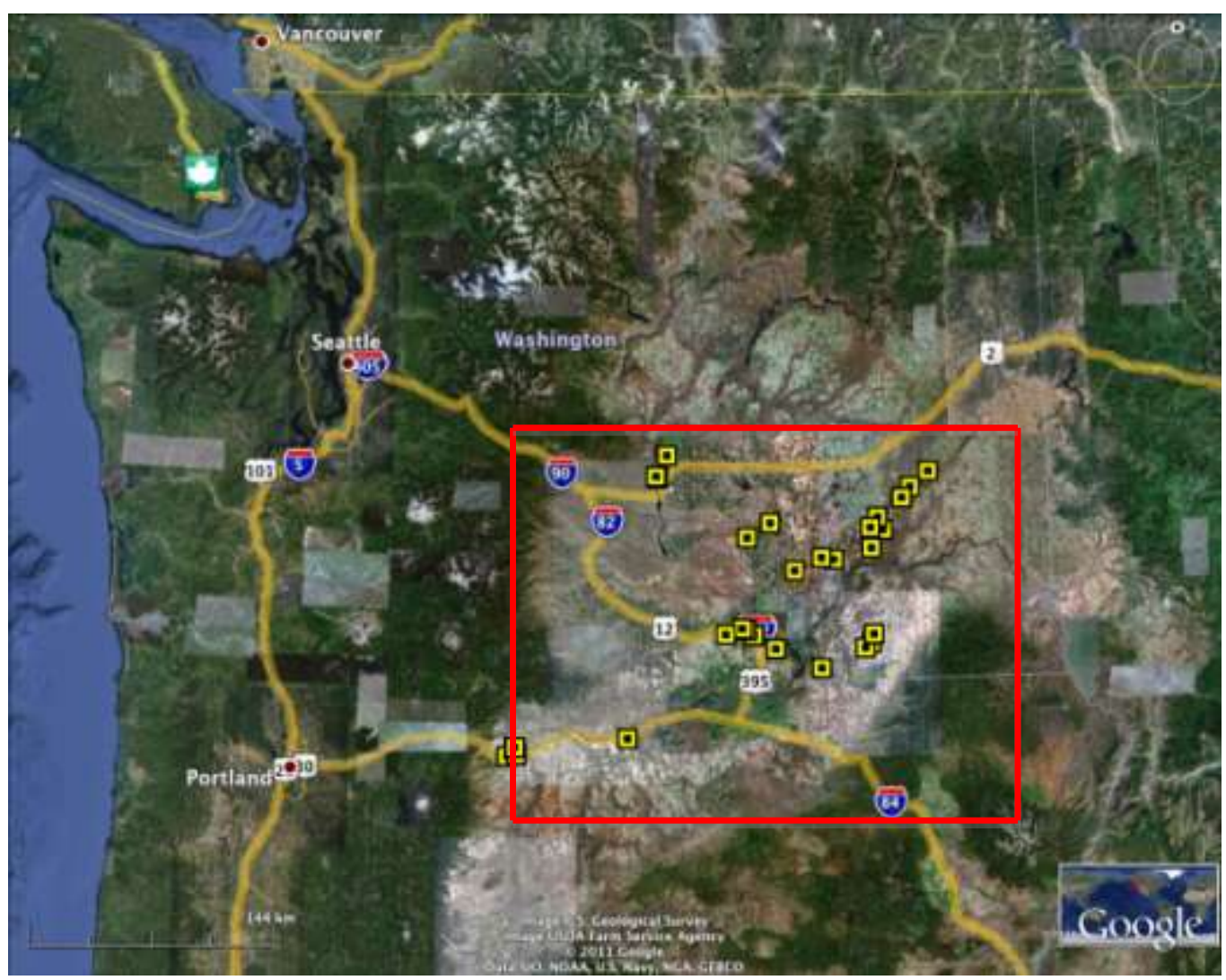

Figure 5 Overview map of Washington and Oregon with field sites of Ancient Cataclysmic Flood deposits represented as yellow squares. The red square shows the location of Figure 6. 


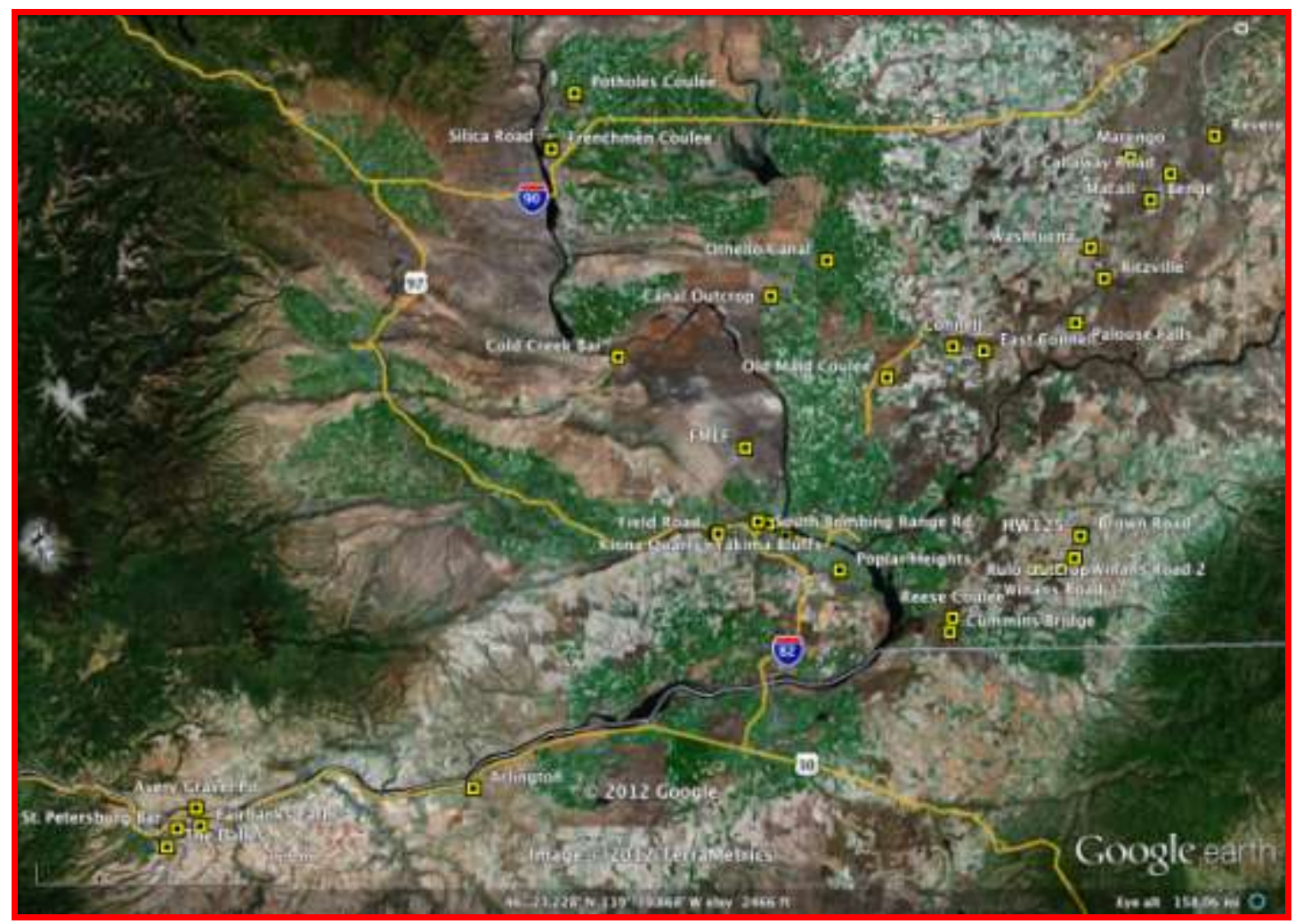

Figure 6 Eastern Washington and Oregon with field sites labeled.

Baker et al. (1991) found evidence of ancient flood deposits at multiple localities in the Pasco Basin in Washington. At some sites they found deposits that had a reversed magnetic polarity. There were also multiple sites in the Pasco Basin where Bjornstad et al. (2001) found paleosols with well developed $\mathrm{CaCO}_{3}$ overlain by Missoula Flood deposits. At one site locality, FMEF (Fuels Material and Examination Facility), they were able to date wood pieces in a clastic dike that truncated two flow deposits. The dike was dated 32,000 radiocarbon years before present, 37.3 ka calendar years before present. The dike must be younger than the two sandy flood deposits it truncates, which means the floods are older than 37.3 years. The sites referenced by Baker et al. (1991) are: Poplar Heights, Yakima Bluffs, 
Kiona Quarry, South Bombing Range Road, Leslie Road, FMEF, Cummings Bridge, Macall, Marengo, Revere, and Washtucna.

In 2001, Bjornstad et al. wrote one of the first articles to compile some of the "Pre-Wisconsin" Ice Age Floods, now termed Ancient Cataclysmic Floods (Allen et al., 2009). The following sites were included and dated using radiometric dating: Kiona Quarry, Leslie Road, Macall, Marengo, Old Maid Coulee, and Yakima Bluffs.

In 2006, Bjornstad wrote an updated field guide to the Columbia Basin. At a site he termed "Evergreen and Babcock Ridges", near Frenchman Coulee, he found evidence for a very old flood with a thick caliche soil overlying very weathered flood gravels. He sites this flood as having an eastward water movement, which is in the opposite direction of the Missoula Floods. At two other sites, Badger Coulee and Cold Creek Bar, he found further evidence of a magnetic reversal, dating the paleosols older than 790,000 years before present.

Kiver et al. (1991) found evidence of episodic flooding along Latah Creek near Spokane, Washington. He dated tephras that show a clear stratigraphic relationship to flood gravels between 30 and 40 thousand radiocarbon years ago. The flood gravels are overlain by Missoula Flood deposits. Kiver correlated these deposits to deposits at the Malden Gravel Pit, Willow Creek, and the Tuscan River Valley.

Most recently, Gastineau (2011) studied the Rulo Outcrop near Walla Walla, Washington. The outcrop has several layers of silt and calcrete development and two tephras dated at $165-210 \mathrm{ka}$ and $>200 \mathrm{ka}$. 
Spencer and Gilk (1999) and Spencer and Jaffee (2002) documented some of the same sites as others but also discovered new sites: Winans Road 1 and 2 also near Walla Walla, Washington.

Evidence of pre-Missoula Floods also reaches into Oregon at one known site. Dave Cordero and Scott Burns studied a roadcut on Oregon Highway 197, three kilometers southeast of The Dalles that contained five paleosols with well developed $\mathrm{CaCO}_{3}$ (Cordero, 1997). The deposits overlie volcaniclastic sediments of The Dalles Formation (Cordero, 1997) and overlain by Missoula Flood rhythmites.

Lastly, workers that have done studies on loess in eastern Washington have found the loess to be interbedded with paleosols, some with magnetic pole reversal evidence. Thick loess deposits that are adjacent to flood coulees provide evidence for flood events. Evidence includes unconformities cut by floods, fining upward sequences in separate loess strata, formation of calcrete horizons in the loess, and slackwater sediment (McDonald and Busacca, 1988a). Baker et al. (1991) found sections of these loess and paleosol beds near Connell, Dusty, Winona, and $7.4 \mathrm{~km}$ west of Washtucna. McDonald and Busacca (1988a) found similar deposits, depicting six different episodes of flooding and some of which have reversed magnetic polarity. In the Pasco Basin, Baker et al. (1991) divided the loess into five different units, three of which they interpreted to be older than the Missoula Floods. Bjornstad (2006) also found a site at Palouse in the Pasco Basin that has loess, reverse magnetic polarity evidence, and Mt. St. Helens "set C" tephra (40 to $36 \mathrm{ka}$ years ago). 


\subsection{Soil Development}

Calcrete is a term used to describe both pedogenic $\mathrm{CaCO}_{3}$ accumulation and $\mathrm{CaCO}_{3}$ accumulation from groundwater genesis (Birkeland, 1999). The carbonate for a pedogenic calcrete is derived from loess and $\mathrm{Ca}^{2+}$ dissolved in rainwater. Eastern Washington is moisture limited so the influx of $\mathrm{Ca}++$ is not the limiting factor. During periods of more rainfall, more $\mathrm{Ca}++$ is leached into the soil. "Groundwater carbonate tends to be more coarsely grained than pedogenic carbonate, fills only the original pore spaces, and because of overburden pressure, has not forced the original grains apart" (Laity, 2008). Quaternary soils in eastern Washington display pedogenic $\mathrm{CaCO}_{3}$ accumulation typical of soils in arid to semiarid climates (Baker, 1973; Baker and Nummedal, 1978; Patton and Baker, 1978; Busacca et al., 1989; Baker et al., 1991; Bjornstad et al., 2001).

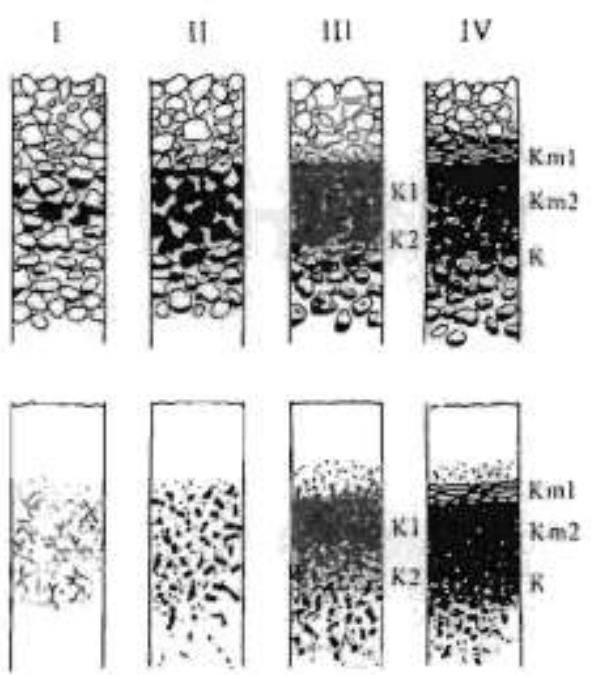

Figure 7 Stages of carbonate morphology for gravelly parent material on top and finegrained soil on the bottom (Birkeland, 1999; based on Gile et al., 1981) 


\begin{tabular}{|c|c|c|}
\hline Stage & Gravelly Parent Material & Nongravelly Parent Material \\
\hline $\mathbf{I}$ & $\begin{array}{l}\text { Discontinuous clast coatings, } \\
\text { about } 4 \% \mathrm{CaCO}_{3}\end{array}$ & $\begin{array}{l}\text { Few coatings on sand grains, }<10 \% \\
\mathrm{CaCO}_{3}\end{array}$ \\
\hline I+ & $\begin{array}{l}\text { All clast coatings thing and } \\
\text { continuous }\end{array}$ & Filaments are common \\
\hline II & Continuous clast coatings & $\begin{array}{l}\text { Few to common nodules, } 10-15 \% \\
\mathrm{CaCO}_{3}\end{array}$ \\
\hline II+ & Carbonate more pervasive & Common nodules, $\sim 15 \% \mathrm{CaCO}_{3}$ \\
\hline III & $\begin{array}{l}\text { Carbonate forming continuous } \\
\text { medium, } 20-25 \% \mathrm{CaCO}_{3}\end{array}$ & Many nodules, $20 \% \mathrm{CaCO}_{3}$ \\
\hline III+ & $\begin{array}{l}\text { Clasts have thick coats and } \\
\text { matrix particles continuously } \\
\text { coated or plugged by } \mathrm{CaCO}_{3}\end{array}$ & $\begin{array}{l}\text { Most grains coated and most pores } \\
\text { plugged by } \mathrm{CaCO}_{3}>40 \%\end{array}$ \\
\hline \multicolumn{3}{|c|}{ Partly or entirely cemented } \\
\hline IV & \multicolumn{2}{|c|}{ Upper K horizon nearly cemented with weak platy structure, $>50 \% \mathrm{CaCO}_{3}$} \\
\hline $\mathbf{V}$ & \multicolumn{2}{|c|}{$\begin{array}{l}\text { Laminar layer and platy structure are strongly expressed; incipient } \\
\text { brecciation and pisolith formation }\end{array}$} \\
\hline VI & \multicolumn{2}{|c|}{ Brecciation and recementation, as well as pisoliths, common } \\
\hline
\end{tabular}

Figure 8 Stages of Carbonate Morphology. Taken from Birkeland (1999). (Gile et al., 1981; modification by R.R. Shroba, 1982; Machette, 1985)

Birkeland (1999) and Gile et al. (1981) mention four stages of development of calcrete morphology (Figure 7). Machette (1985) expanded these stages of development to six stages (Figure 8). I will use Machette (1985) for stages of development in this thesis. The stage of soil development is useful for determining the relative age of the flood deposits. Each stage of soil development takes a certain amount of time to form; using the percentage of $\mathrm{CaCO}_{3}$ and paleosol morphology, the relative age of underlying flood deposits can be determined. "Soil development atop the last cataclysmic (late Wisconsin) flood deposits ( $15 \mathrm{ka})$ [is] weak (Stage I or less), alteration [is] limited to calcareous filaments and/or nodules in fine grained soils, and thin carbonate [is] found on the undercoatings of gravel clasts within coarser-textured soils. In contrast, pre-Wisconsin (i.e., >130 ka) flood deposits are 
typically capped with a >1-m-thick pedogenic calcrete (Stages III-IV), consisting of one or more platy, well-cemented, calcic horizons with massive to laminar secondary $\mathrm{CaCO}_{3}$ completely filling the matrix" (Bjornstad et al., 2001). Pedogenic calcrete with more than $50 \% \mathrm{CaCO}_{3}$ requiring hundreds of thousands to millions of years to develop (Machette, 1985).

\subsection{Unconformities}

An unconformity is a buried erosion surface and represents missing time between the underlying and overlying deposits. Several "loess islands" located in depositional areas in the Channeled Scablands are adjacent to erosional areas that have been scoured by floods. Several unconformities truncate loess layers and are interpreted as being cut by floods (McDonald and Busacca, 1988a). Loess and gravel sites that have multiple paleosols separated by unconformities provide evidence for missing time periods. By determining the stage of soil development of each paleosols, minimum ages for the exposure of each surface can be determined.

\subsection{Exotic Clasts}

A thick layer of Columbia River Basalt underlies most of the Channeled Scablands in eastern Washington and Oregon (Allen et al., 2009). Therefore, clasts of other lithologies are of particular importance. Granites and low-grade metamorphic rocks and other exotic clasts of pebble to boulder size are found within the Touchet Beds and suggest a different mode of transport, possibly ice-rafting (Fecht and Tallman, 1978). 


\subsection{Truncated Clastic Dikes}

Clastic dikes that truncate older flood deposits are present at several sites. "The dikes signify soft-sediment deformation during or soon after flooding, perhaps associated with flood-induced seismicity (Bjornstad et al., 2001)." The dikes do not provide proof for pre-Wisconsin flooding because the timing relative to the flood deposits is unknown. However, they help support other stratigraphic evidence depending on the degree of weathering along the youngest truncated horizon. The dikes often truncate advanced stages of paleosol development and reversed magnetic polarity horizons.

\subsection{Reversed Magnetic Polarity}

Many flood deposits and loess deposits have been analyzed for magnetic polarity. The Brunhes-Matuyama magnetic reversal is dated at $790 \mathrm{ka} \mathrm{(+/-20)}$ (Johnson, 1982); therefore, sediments with reversed magnetic polarity were deposited at least $790 \mathrm{ka}$. It is a good method at distinguishing Early Pleistocene from Middle Pleistocene and for relative dating because reversed magnetism means the deposit as well as the underlying deposits are at least 790,000 years old. 


\section{Chapter 3: Methods}

\subsection{Literature Review}

All previous publications on the Missoula Floods and potentially older flood deposits were compiled. The literature was searched for specific site localities where older flood deposits might exist. The sites were added to a spreadsheet with their precise location and a brief summary of the geology. The sites were then added to a topographic map using Google Earth.

\subsection{Field Data Collection}

Each site mentioned in literature was visited, except sites in the northeast part of the Channeled Scablands, the sites of Kiver et al. (1991). At each site the following were collected: photographs, Global Positioning System (GPS) coordinates, and samples. Samples were collected from each stratigraphic horizon at each site, which could include Missoula Flood sediments, calcrete paleosols, ancient flood gravels, loess, and rhythmites.

In addition to visiting most of the sites mentioned by other workers, new sites were searched for by driving through as many roadcuts as possible in the Channeled Scablands. The criteria for finding a new site were elevation and the presence of a calcrete paleosol. Several modern gravel pits and quarries with presumed "Missoula Flood" gravels were also sampled as a basis of comparison for the ancient flood gravels. 


\subsection{Laboratory Methods}

All samples were tested for their $\mathrm{CaCO}_{3}$ content using the Chittick

Apparatus (Figure 9). The method, first implemented by Dreimanis (1962) then modified by Machette (1986), is based on the volumetric evolution of carbon dioxide when carbonates react with dilute hydrochloric acid. Five splits of each sample were analyzed. The average of the splits with calculated standard mean error is shown in the Results. A more detailed methodology of the Chittick Apparatus procedures performed for this thesis is in Appendix A.

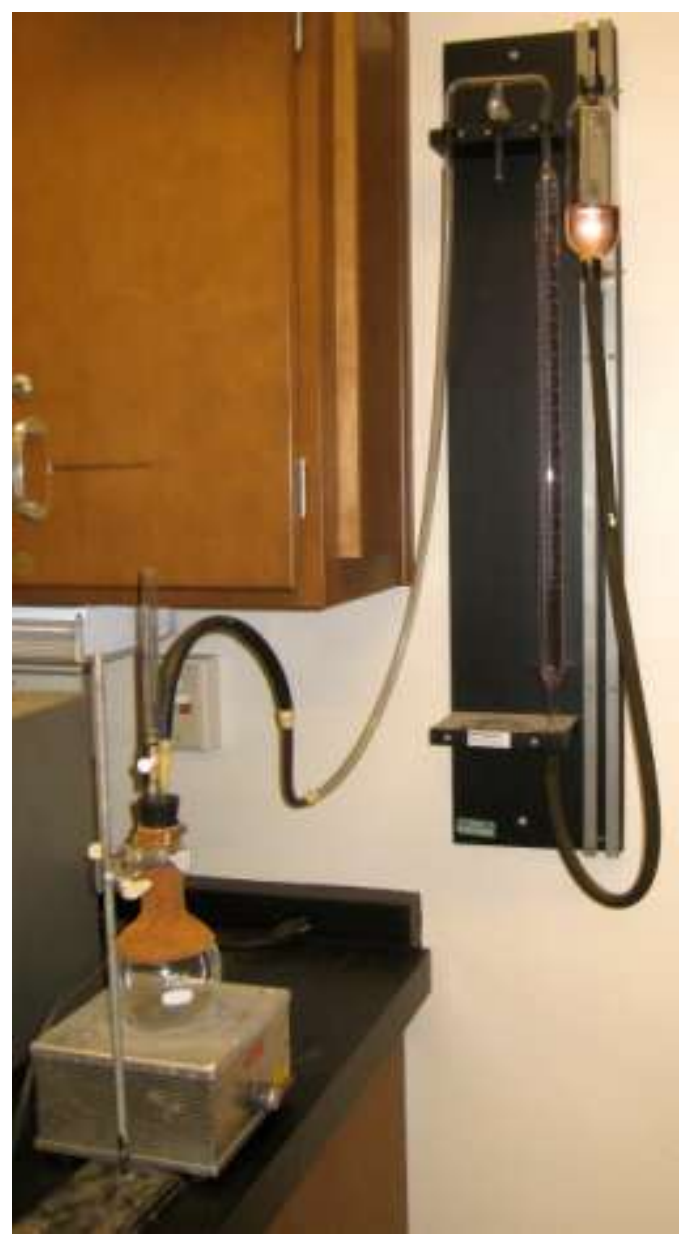

Figure 9 Chittick apparatus. 
The results from the Chittick apparatus were calculated by converting amount of carbon dioxide to $\mathrm{CaCO}_{3}$ using the formula in Appendix A. The percentage of $\mathrm{CaCO}_{3}$ was assigned a stage of calcrete soil development based on the classification system of Machette (1985) (Figure 8). After determining the stage of soil development, the relative ages of paleosols and flood deposits were determined.

Table 1 Stages of carbonate morphology (modified from Machette (1985)).

\begin{tabular}{|cc|}
\hline Stage & Percent $\mathrm{CaCO}_{3}$ \\
\hline Stage I & $0.0-2.9$ \\
\hline Stage II & $3.0-11.9$ \\
\hline Stage II+ & $12.0-16.9$ \\
\hline Stage III & $17.0-34.9$ \\
\hline Stage III+ & $35.0-49.9$ \\
\hline Stage IV & $50.0-74.9$ \\
\hline Stage V & $>75.0$ \\
\hline
\end{tabular}

The Pleistocene is broken up into three age ranges: Early Pleistocene from 2.58 Ma - 781 ka, Middle Pleistocene from 781-126 ka, and Late Pleistocene from 126 ka to 11,700 (Morrison, 1991). However, all pre-Missoula Flood (15 - 18 ka) deposits were termed "Middle Pleistocene" in this thesis to differentiate them from the Late Pleistocene Missoula Flood deposits. Early to Middle Pleistocene deposits ranged from Stage II to III+ soil development. Late Pleistocene Missoula Flood deposits contained only Stage $\mathrm{I} \mathrm{CaCO}_{3}$.

Two samples of slackwater deposits and loess deposits were analyzed for grain size analysis using the pipette method (Gee and Bauder, 1986). The detailed methodology I used for this thesis is explained in Appendix B. The results were analyzed to determine the percentages of sand, silt, and clay for each sample. 
Slackwater flood deposits should have more sand and gravel in them than loess deposits.

All field notes are listed in Appendix C. 


\section{Chapter 4: Results}

The field sites mentioned in literature as well as newly discovered field sites (Figure 6) are described in more detail below. Google maps with a close-up of the field site location as well as the precise GPS coordinates are given for each site. Each site description includes relevant pictures of the outcrop with sample locations labeled. Layers are separated by blue lines and unconformities are labeled as red lines. If the samples collected were tested for the amount of $\mathrm{CaCO}_{3}$, the results and stage of the calcrete development are given in a table based on carbonate morphology (Figure 8) and percent $\mathrm{CaCO}_{3}$ in the sample (Table 1). Each sample is described: calcrete paleosols should have high $\mathrm{CaCO}_{3}$ values whereas the underlying slackwater deposits, fluvial gravels and loess, should be much lower. If the sites are not newly discovered, the findings of previous scientists are discussed.

A total of 29 field sites are studied in this thesis. Four of the sites are Missoula Flood-aged gravel pits, studied for a basis of comparison of "Missoula Flood" deposits to "Ancient Cataclysmic Flood" deposits. Eleven of the sites are newly discovered possible Ancient Cataclysmic Flood sites.

The sites are divided into Missoula Flood gravel pits, loess outcrops, and flood deposits. The loess outcrops are adjacent to flood scoured channels and contain evidence that correlates to Ancient Cataclysmic Floods. Flood deposits record high energy floods at sites that have flood gravels and low energy floods at places with slackwater flood deposits and rhythmites. Table 2 summarizes the GPS location in decimal degrees, elevation, and references for each field site. 
Table 2 Complete list of field sites from west to east with GPS location, elevation, and reference.

\begin{tabular}{|c|c|c|c|c|}
\hline Field Site & $\begin{array}{c}\text { Latitude } \\
\text { (degree decimal) }\end{array}$ & $\begin{array}{c}\text { Longitude } \\
\text { (decimal degree) }\end{array}$ & Elevation (m) & Reference \\
\hline The Dalles & 45.578519 & -121.104914 & 284.0 & Cordero (1997) \\
\hline St. Petersburg Bar & 45.617268 & -121.074666 & 120.7 & Missoula Flood gravel pit \\
\hline Avery Gravel Pit & 45.662232 & -121.018684 & 80.0 & Missoula Flood gravel pit \\
\hline Fairbanks Farm & 45.626514 & -121.005139 & 158.5 & Missoula Flood gravel pit \\
\hline Arlington & 45.712292 & -120.192113 & 164.0 & Missoula Flood gravel pit \\
\hline Silica Road & 47.046525 & -119.976711 & 402.0 & NEW \\
\hline Frenchmen Coulee & 47.042778 & -119.970768 & 413.0 & Bjornstad 2006 \\
\hline Potholes Coulee & 47.160043 & -119.901514 & 388.0 & Bjornstad 2006 \\
\hline Cold Creek Bar & 46.611200 & -119.764714 & 313.9 & Bjornstad 2006 \\
\hline Field Rd. & 46.245089 & -119.467444 & 165.2 & NEW \\
\hline FMEF & 46.421036 & -119.372827 & 158.5 & Baker et al. 1991 \\
\hline $\begin{array}{l}\text { South Bombing } \\
\text { Range Rd. }\end{array}$ & 46.269697 & -119.342790 & 174.7 & Baker et al. 1991 \\
\hline Yakima Bluffs & 46.265312 & -119.313353 & 148.7 & $\begin{array}{c}\text { Baker et al. 1991, Fecht et } \\
\text { al. } 1999\end{array}$ \\
\hline Canal Outcrop & 46.738063 & -119.303453 & 301.0 & NEW \\
\hline Leslie Road & 46.239699 & -119.259859 & 118.0 & Baker et al. 1991 \\
\hline Othello Canal & 46.811680 & -119.131982 & 329.0 & NEW \\
\hline Poplar Heights & 46.168759 & -119.098520 & 146.0 & Bjornstad 2006 \\
\hline Old Maid Coulee & 46.568056 & -118.952637 & 277.0 & Bjornstad \\
\hline Cummins Bridge & 46.037963 & -118.768358 & 117.0 & $\begin{array}{c}\text { Bjornstad et al. } 1980, \\
\text { Moody } 1987\end{array}$ \\
\hline
\end{tabular}




\begin{tabular}{|llllc|}
\hline Reese Coulee & 46.067093 & -118.759732 & $\mathbf{1 9 3 . 0}$ & Bjornstad \\
\hline Connell & 46.631671 & -118.752708 & $\mathbf{3 4 9 . 0}$ & Busacca \\
\hline East Connell & 46.621870 & -118.659126 & $\mathbf{3 8 4 . 0}$ & NEW \\
\hline Rulo Outcrop & 46.165369 & -118.502400 & $\mathbf{2 9 9 . 9}$ & Gastineau 2011 \\
\hline Winans Road 1 & 46.166671 & -118.432645 & $\mathbf{2 8 6 . 2}$ & Spencer and Jaffee 2002 \\
\hline Winans Road 2 & 46.188467 & -118.391303 & $\mathbf{2 9 1 . 1}$ & Spencer and Jaffee 2002 \\
\hline Palouse & 46.677697 & -118.378030 & $\mathbf{3 9 4 . 0}$ & NEW \\
\hline HW125 & 46.234457 & -118.372790 & $\mathbf{3 0 2 . 7}$ & NEW \\
\hline Brown Road & 46.237280 & -118.369293 & $\mathbf{3 1 1 . 2}$ & NEW \\
\hline Washtucna & & & & McDonald and Busacca \\
\hline Ritzville & 46.834753 & -118.328585 & $\mathbf{5 0 1 . 0}$ & 1988 \\
\hline Marengo & 46.769984 & -118.288106 & $\mathbf{3 4 1 . 0}$ & Busacca \\
\hline Benge & 47.020214 & -118.200967 & $\mathbf{4 9 3 . 5}$ & Busaca 1988, McDonald \\
\hline & & & and Busacca 1988 \\
\hline Macall & 46.932452 & -118.142050 & $\mathbf{5 0 6 . 6}$ & Baker 1978, Patton and \\
\hline Callaway Rd. & 46.986710 & -118.078691 & $\mathbf{5 2 4 . 9}$ & Baker 1978, Baker et al \\
\hline & & & & Baker 1978, Patton and \\
Revere & 47.064726 & -117.939204 & $\mathbf{5 1 2 . 0}$ & Baker 1978, Baker et al. \\
\hline
\end{tabular}




\subsection{Missoula Flood Gravel Pits}

Missoula Flood gravel pits were sampled in order to examine the degree of calcrete development in flood deposits of known ages. Several different gravel pits throughout the Columbia River Gorge were sampled at different elevations to see the range of $\mathrm{CaCO}_{3}$ values for Missoula Flood deposits of various ages.

\subsubsection{Avery Gravel Pit (Wishram, Washington)}

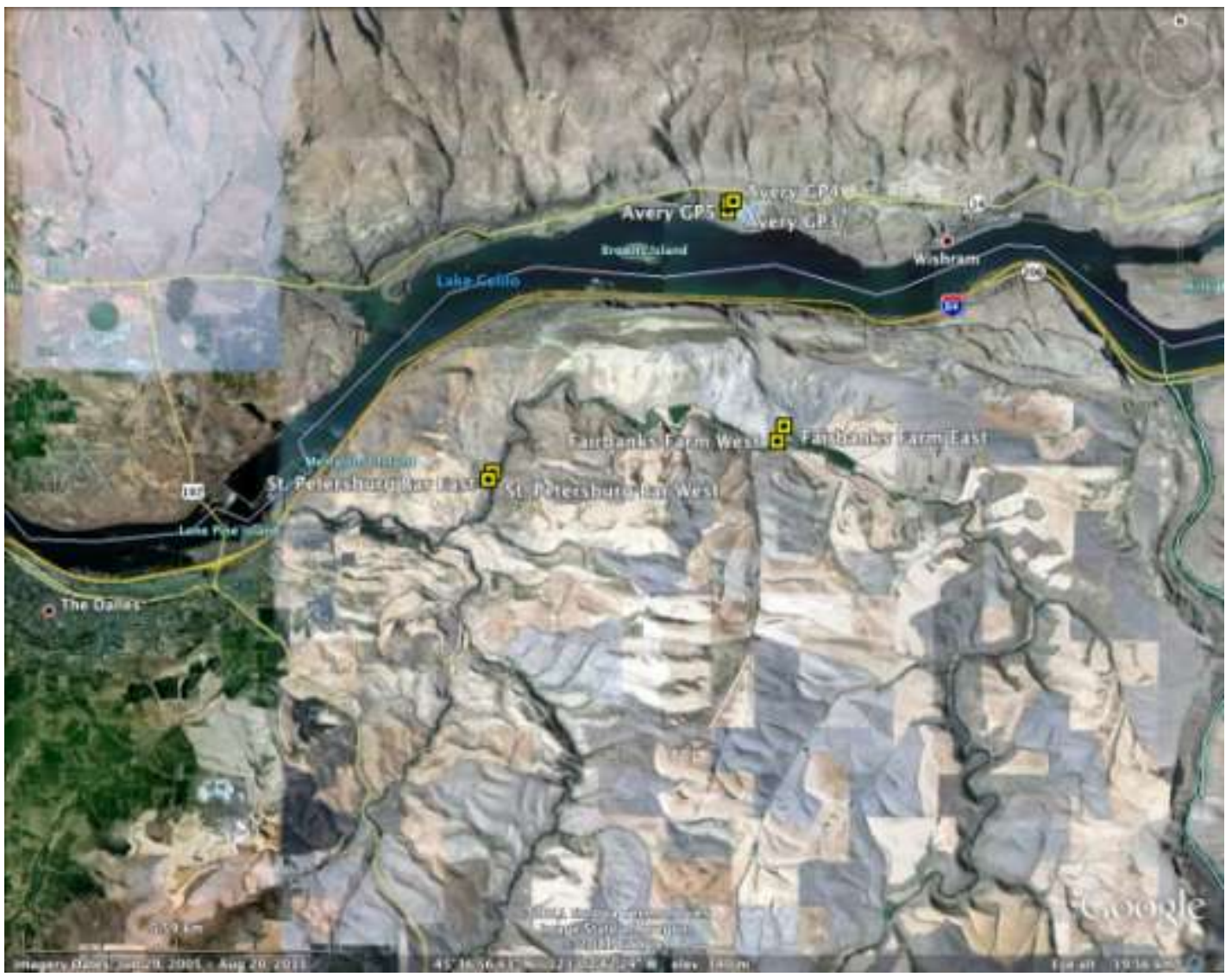

Figure 10 Location of the Avery Gravel Pit field site. 


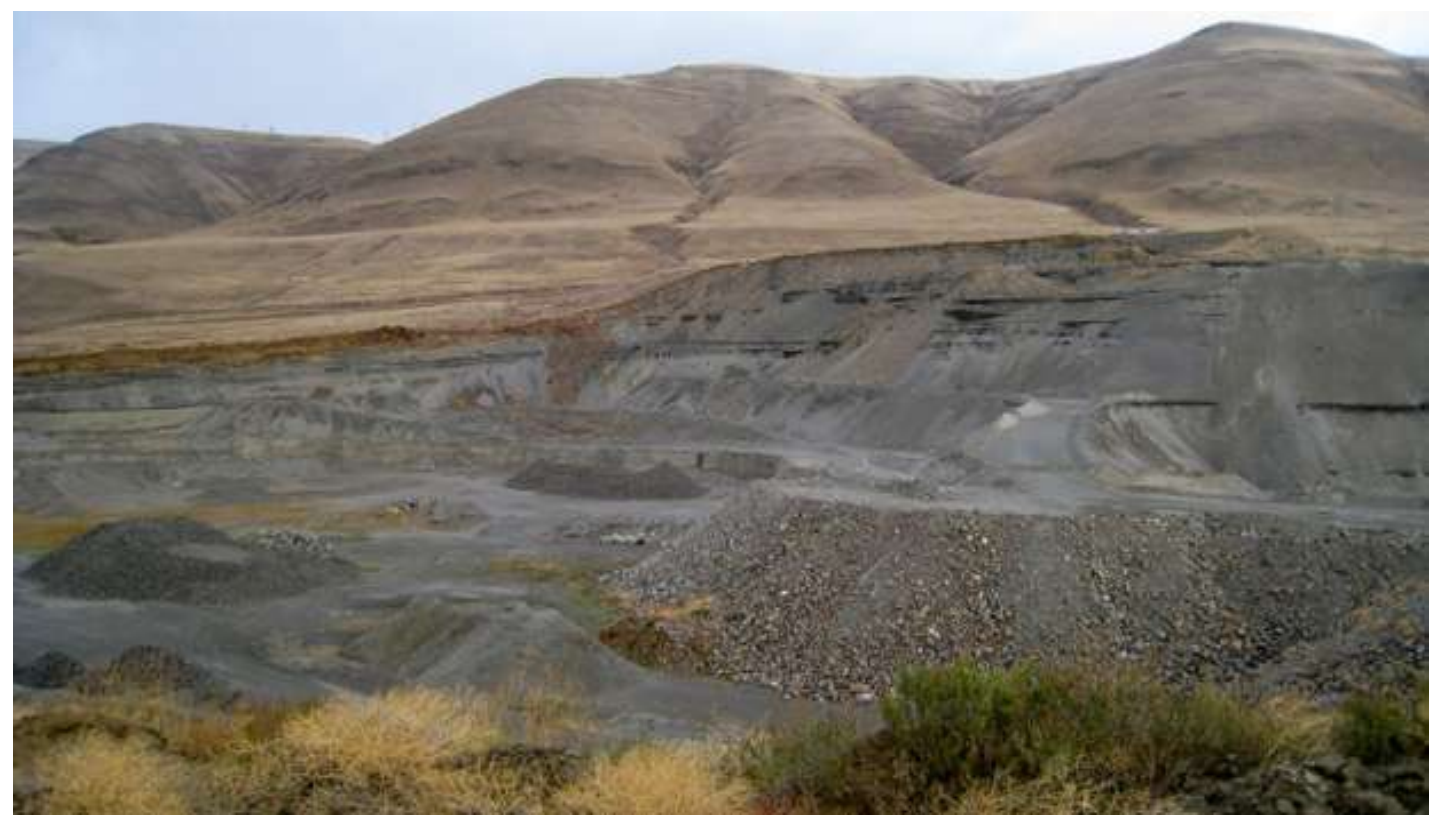

Figure 11 Overview of Avery Gravel Pit showing the lower and upper section sampled.

Avery gravel pit, owned by Tripco, Inc., located $16 \mathrm{~km}$ east of The Dalles, Oregon, on the Washington side of the Columbia River (Figure 10) is an actively mined pit for sands and gravels. The GPS coordinates for this site are N 46.662232 latitude and W -121.018684 longitude; the elevation is $80 \mathrm{~m}$. Each sample was collected from a stratigraphically higher location from A1 (bottom of the pit) to A8 (top of the pit) (Figure 11). The flood gravels are composed of mainly basalt clasts, but exotics are present. Samples AV1-AV6 collected at Avery Gravel Pit measured between $1.0 \% \pm 0.0$ and $1.9 \% \pm 0.3 \mathrm{CaCO}_{3}$, placing them all at Stage I development. AV7 and AV8 contain significantly less calcrete development (0.6 - 0.5\%, Stage 1). The gravelly flood deposits are all Missoula Flood deposits, Late Wisconsin in age. 


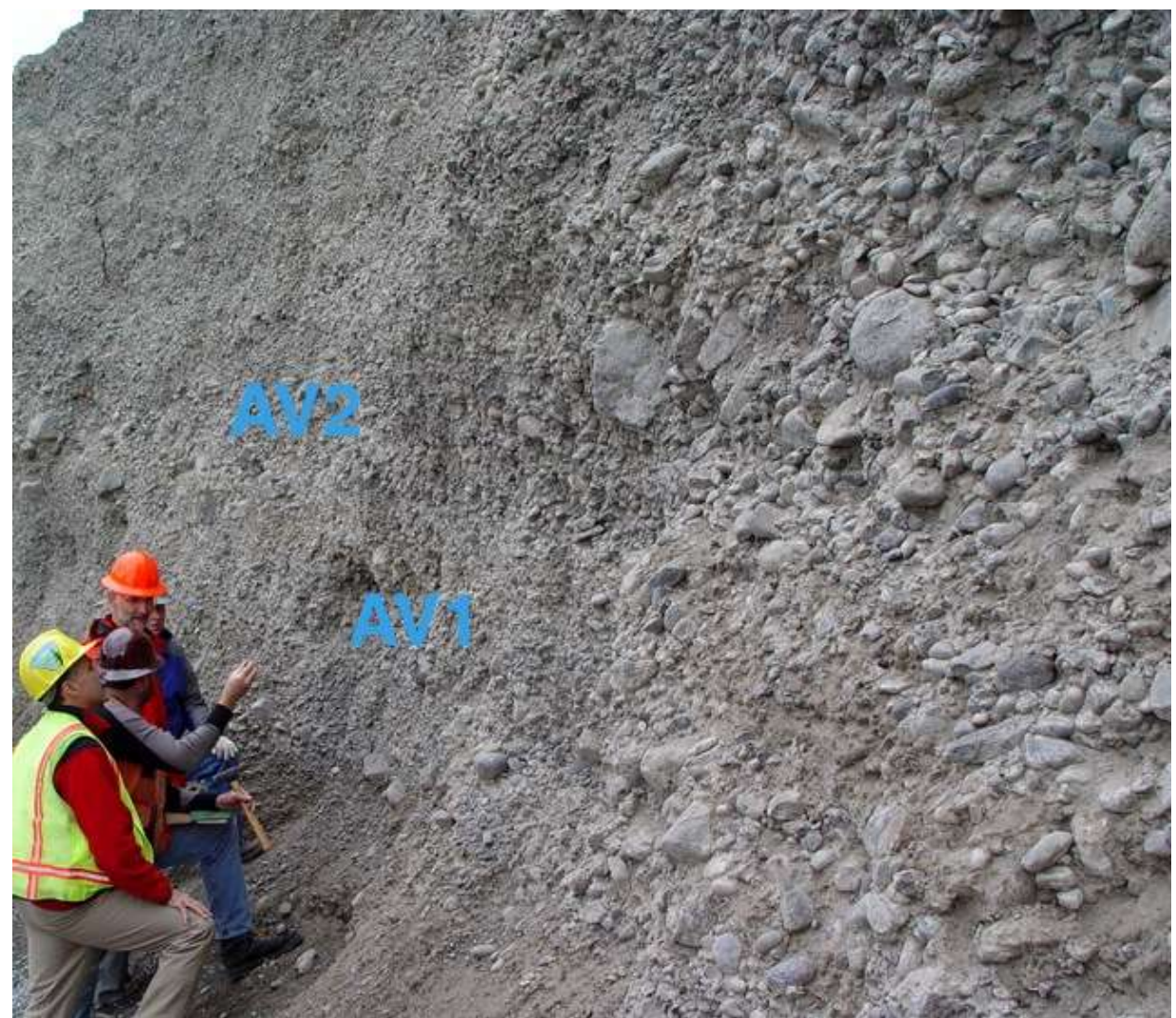

Figure 12 Lower flood gravel section at Avery Gravel Pit with sample locations labeled.

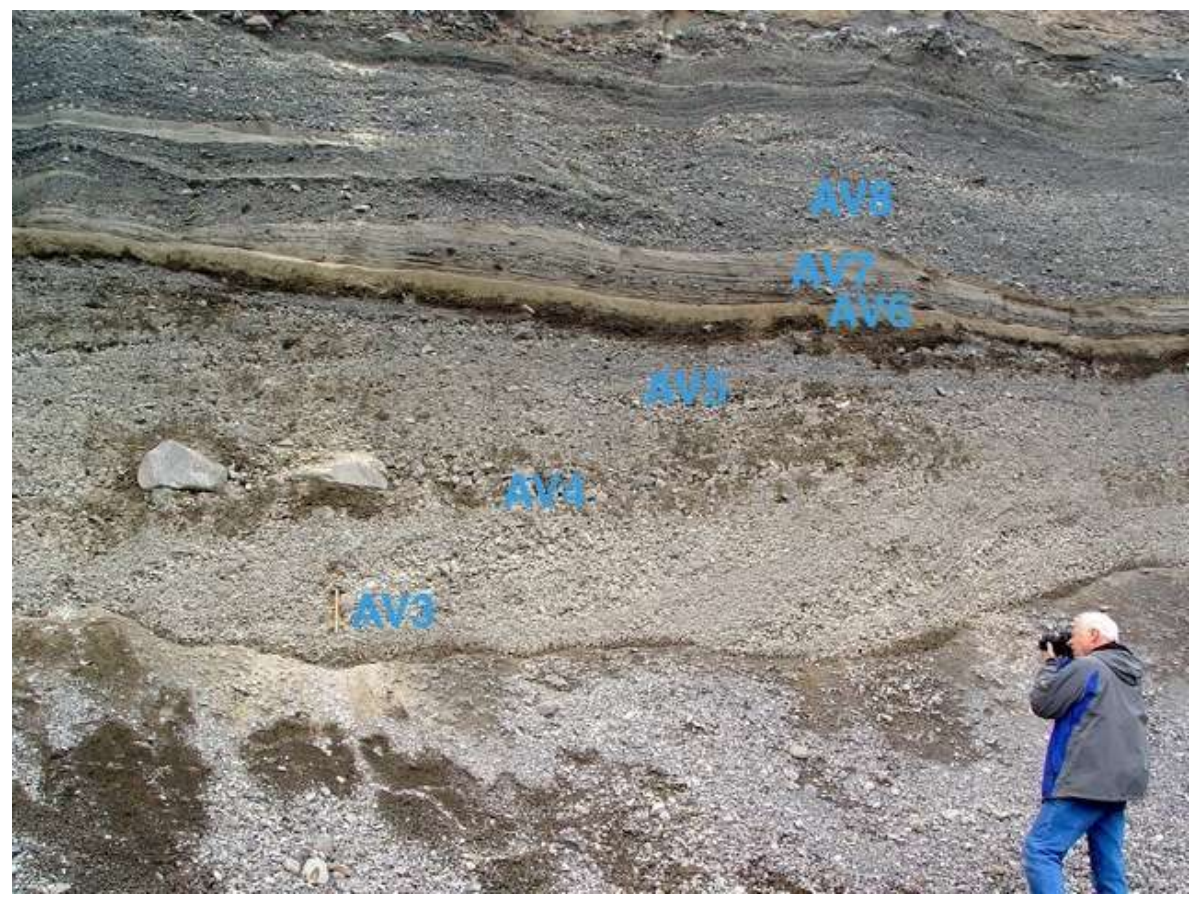

Figure 13 Upper flood gravel section at Avery Gravel Pit with sample locations labeled. 
Table 3 Chittick results for Avery Gravel Pit site.

\begin{tabular}{|l|ll|}
\hline \multicolumn{1}{|c|}{ Sample ID } & $\begin{array}{c}\text { Average } \\
\mathrm{CaCO}_{3} \\
\text { Percent }\end{array}$ & $\begin{array}{c}\text { Stage of } \\
\text { Development }\end{array}$ \\
\hline AV1 Missoula Flood gravels & $1.3 \pm 0.0$ & Stage I \\
\hline AV2 Missoula Flood gravels & $1.6 \pm 0.0$ & Stage I \\
\hline AV3 Missoula Flood gravels & $1.0 \pm 0.1$ & Stage I \\
\hline AV4 Missoula Flood gravels & $1.0 \pm 0.1$ & Stage I \\
\hline AV5 Missoula Flood gravels & $1.9 \pm 0.3$ & Stage I \\
\hline AV6 Missoula Flood gravels & $1.2 \pm 0.1$ & Stage I \\
\hline AV7 Missoula Flood gravels & $0.6 \pm 0.1$ & Stage I \\
\hline AV8 Missoula Flood gravels & $0.5 \pm 0.0$ & Stage I \\
\hline
\end{tabular}

\subsubsection{St. Petersburg Bar (The Dalles, Oregon)}

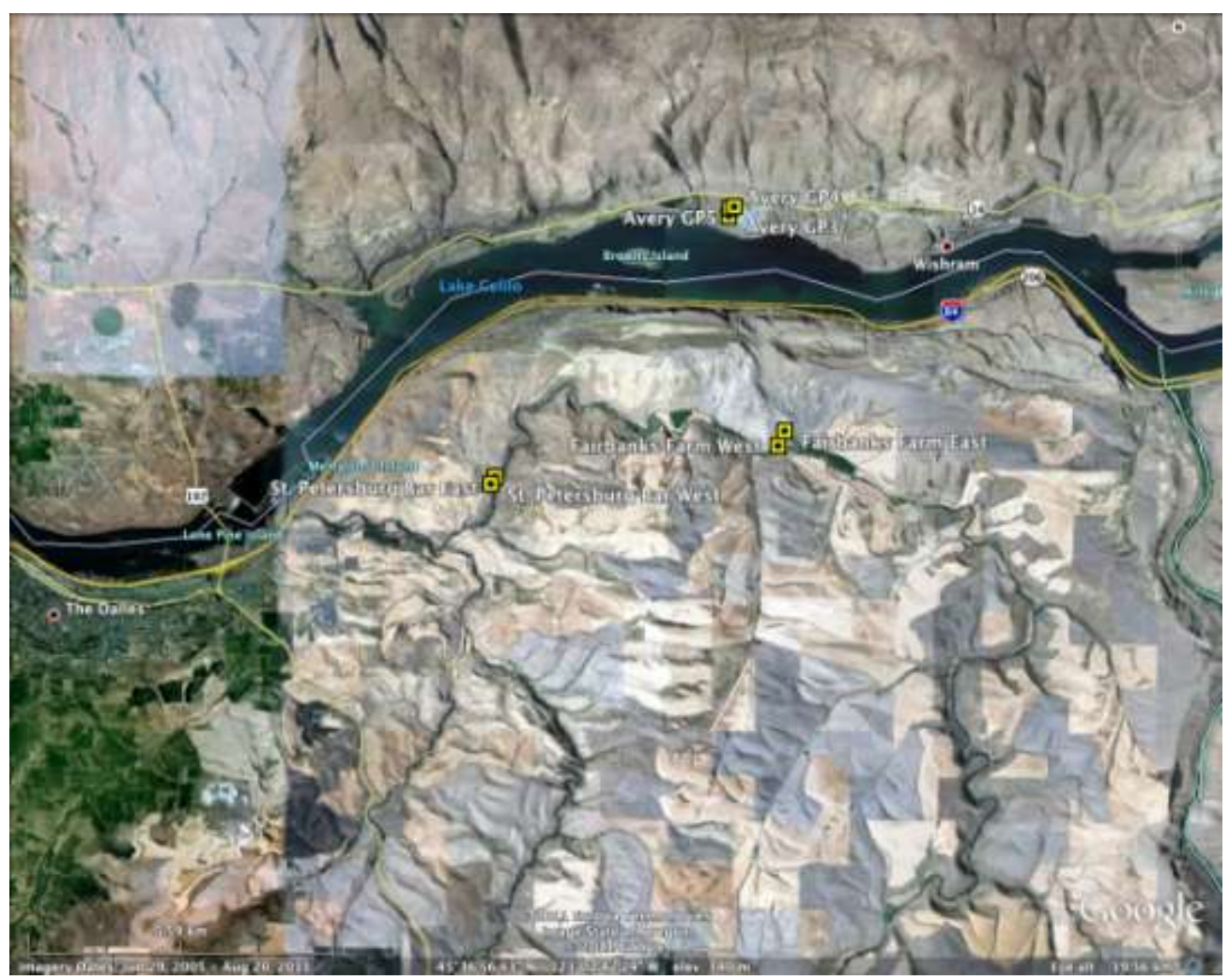

Figure 14 Location of the St. Petersburg Bar field site. 


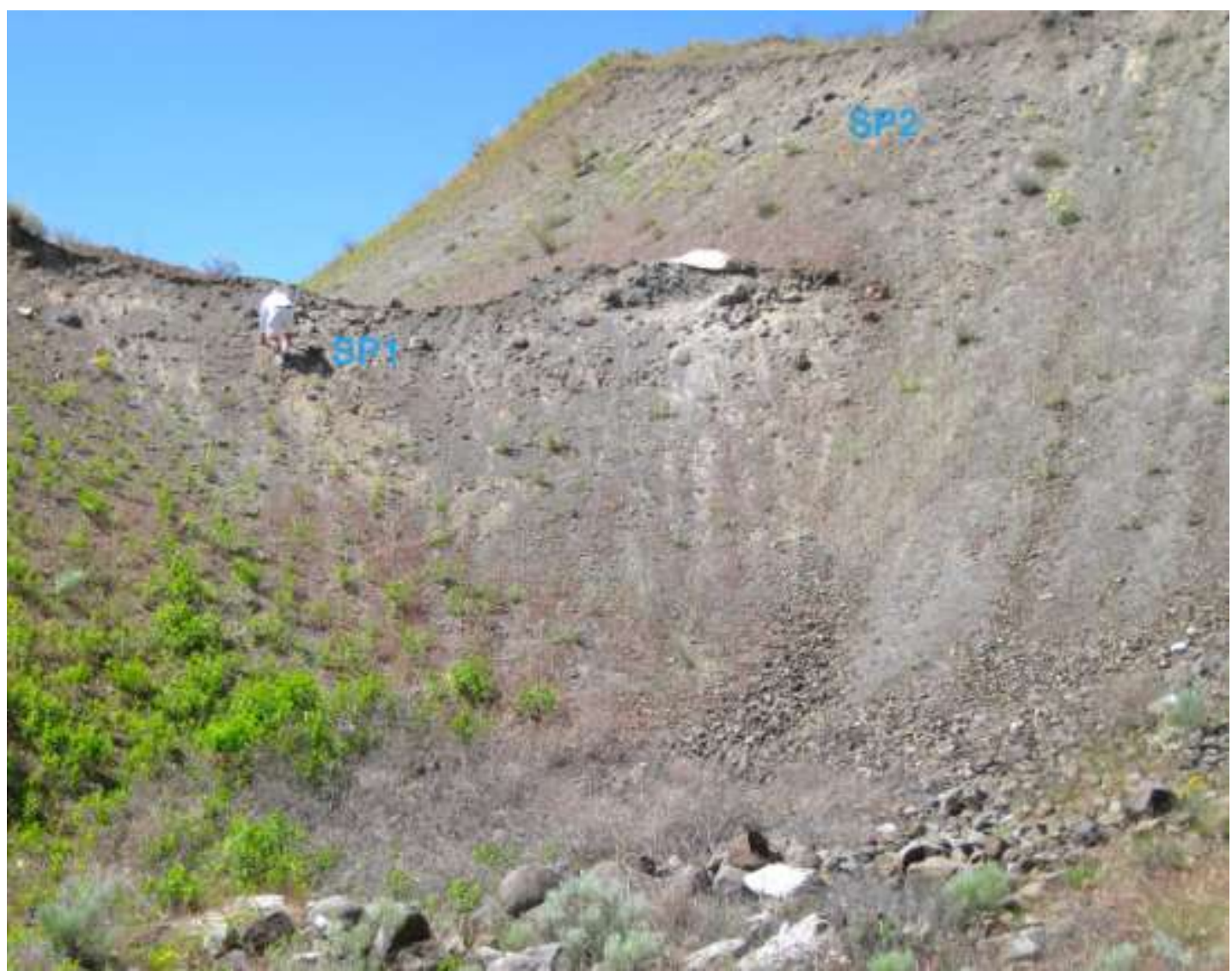

Figure 15 West end of St. Petersburg Bar gravel pit with sample locations labeled.

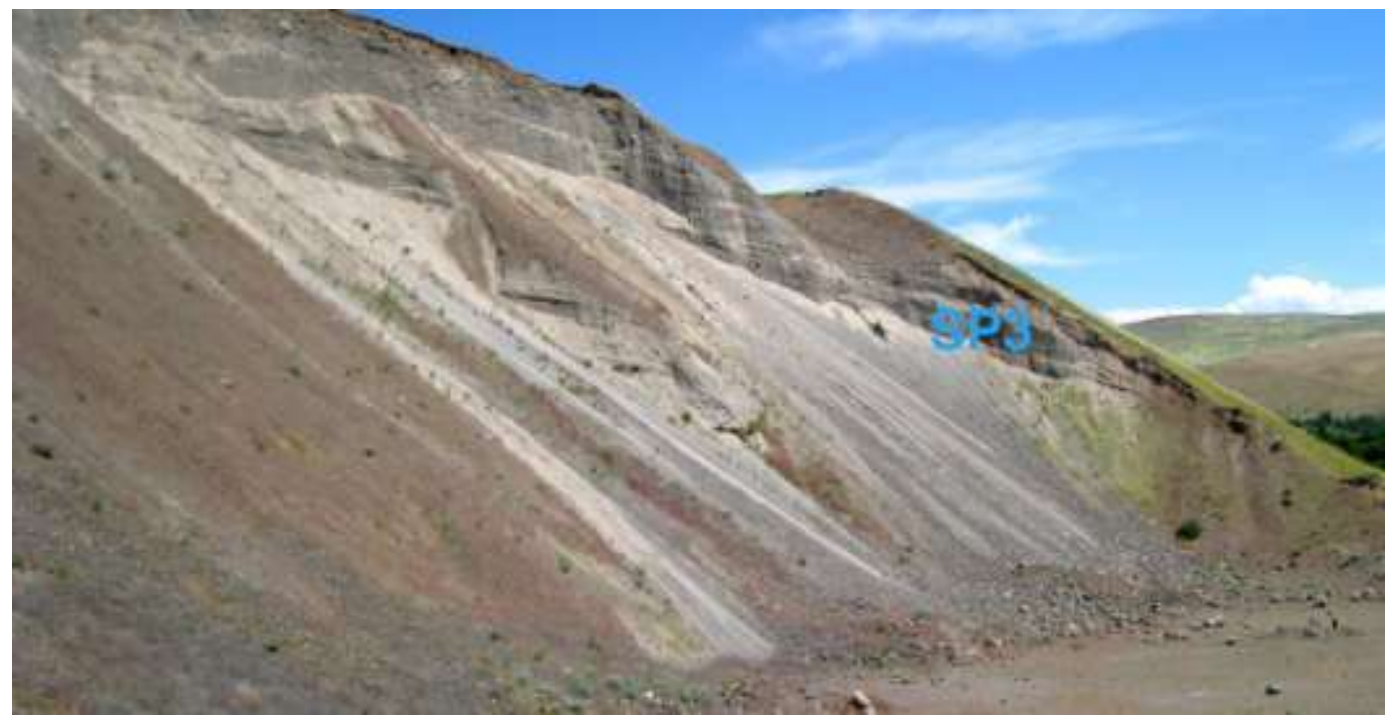

Figure 16 East end of St. Petersburg Bar gravel pit with sample location labeled. 
One thick gravel unit is present, with gravels composed of basalt, pumice, and exotics. Benito and O'Connor (2003) dated St. Petersburg Bar in two locations yielding dates of $14,480 \pm 145$ and $16,720 \pm 210$. There is a weak development of $\mathrm{CaCO}_{3}$, Stage I, with coatings on the underside of clasts (Birkeland, 1999). Samples SP1 and SP2 were collected from the west end of the gravel pit; SP2 is approximately 12 meters upsection from SP1 (Figure 15). SP3 was collected from the east end of the outcrop (Figure 16). Each of the three samples contained approximately the same amount of $\mathrm{CaCO}_{3}: 1.7 \% \pm 0.2,1.7 \% \pm 0.1,1.8 \% \pm 0.2$ (Table 4).

Table 4 Chittick results for St. Petersburg Bar site.

\begin{tabular}{|lcc|}
\hline Sample ID & $\begin{array}{c}\text { Average } \mathrm{CaCO}_{3} \\
\text { Percent }\end{array}$ & $\begin{array}{c}\text { Stage of } \\
\text { Development }\end{array}$ \\
\hline SP1 Missoula Flood gravels & $1.7 \pm 0.2$ & Stage I \\
\hline SP2 Missoula Flood gravels & $1.7 \pm 0.1$ & Stage I \\
\hline SP3 Missoula Flood gravels & $1.8 \pm 0.2$ & Stage I \\
\hline
\end{tabular}

\subsubsection{Fairbanks Farm (The Dalles, Oregon)}

Fairbanks Farm is another Missoula Flood gravel pit field site. It is located east of St. Petersburg bar along 15 Mile Road at its intersection with Company Hollow Road (Figure 17). The GPS coordinates for this site are N 45.626514 latitude and $\mathrm{W}-121.005139$ longitude; the elevation is $158.5 \mathrm{~m}$. The samples were taken from the sample gravel unit composed of primarily basalt gravels, and FF2 is 20 meters east of FF1 (Figure 18). Sample FF1 measured 1.7\% $\pm 0.2 \mathrm{CaCO}_{3}$ and FF2 measured $0.8 \% \pm 0.7$ (Table 5). 


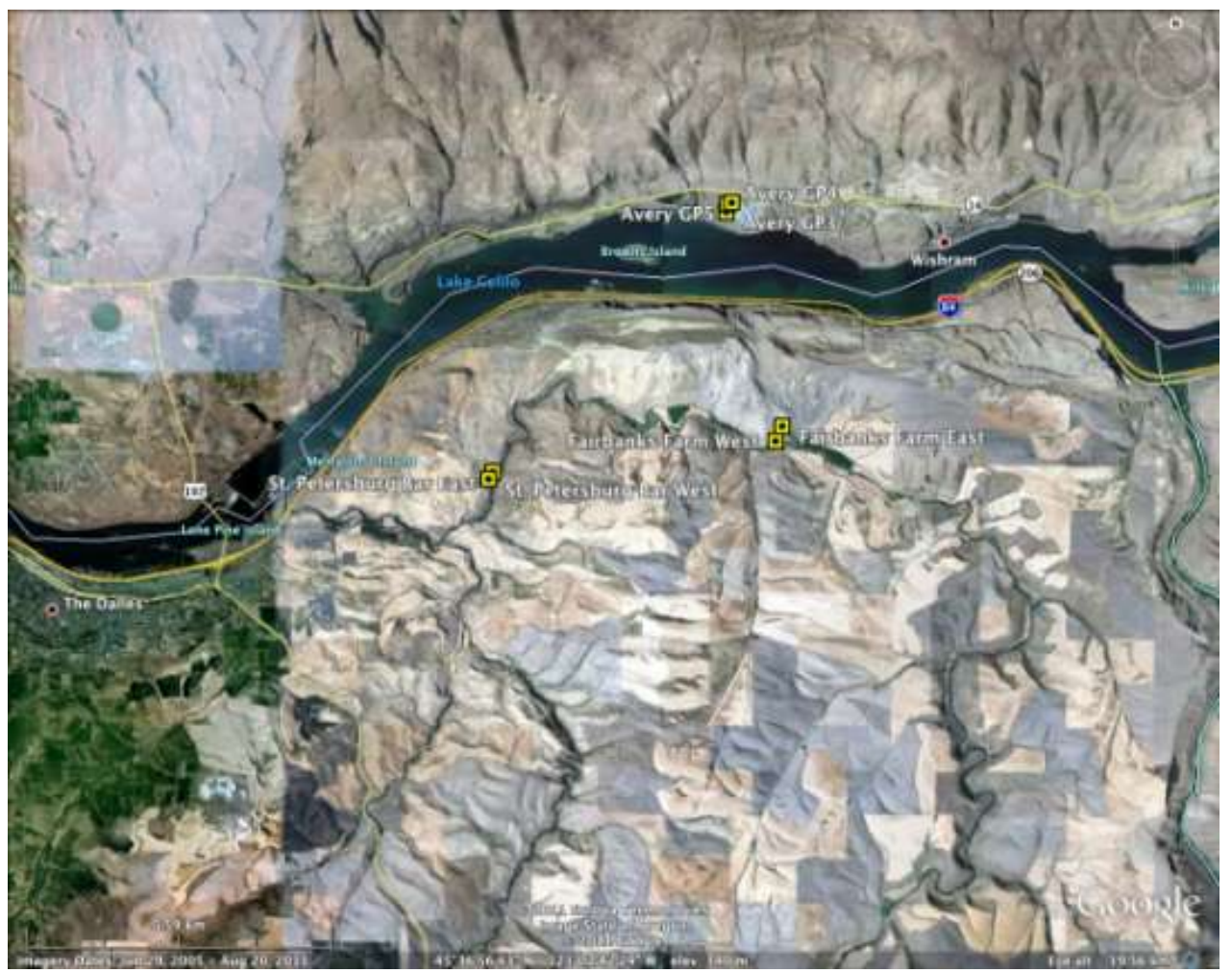

Figure 17 Location of the Fairbanks Farm field site near The Dalles, Oregon.

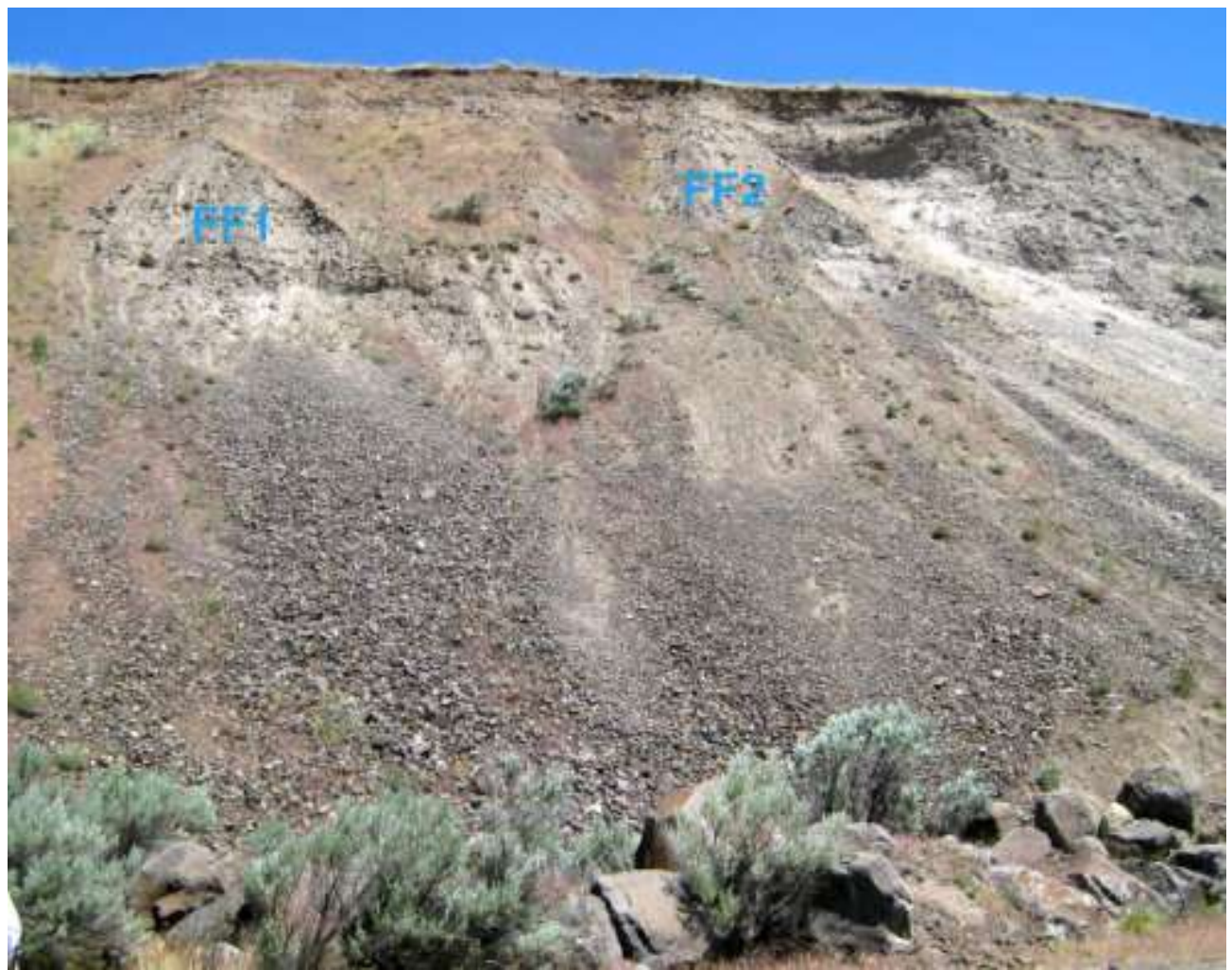

Figure 18 Fairbanks Farm outcrop with sample locations labeled. 
Table 5 Chittick results for Fairbanks Farm site.

\begin{tabular}{|lcc|}
\hline \multicolumn{1}{|c|}{ Sample ID } & $\begin{array}{c}\text { Average } \\
\mathrm{CaCO}_{3} \\
\text { Percent }\end{array}$ & $\begin{array}{c}\text { Stage of } \\
\text { Development }\end{array}$ \\
\hline FF1 Missoula Flood gravels & $1.7 \pm 0.2$ & Stage I \\
\hline FF2 Missoula Flood gravels & $0.8 \pm 0.7$ & Stage I \\
\hline
\end{tabular}

\subsubsection{Arlington (Arlington, Oregon)}

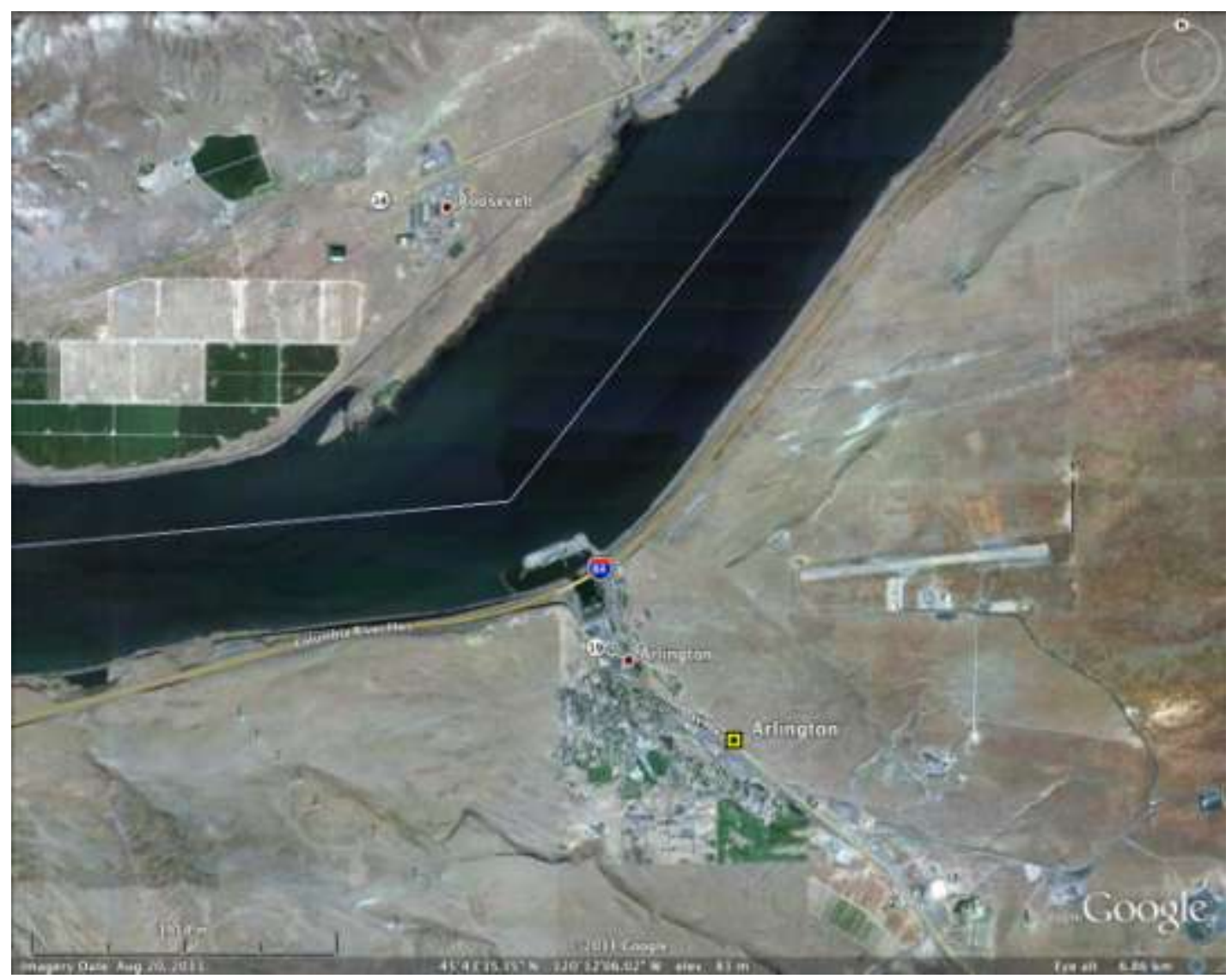

Figure 19 Location of the Arlington field site. 


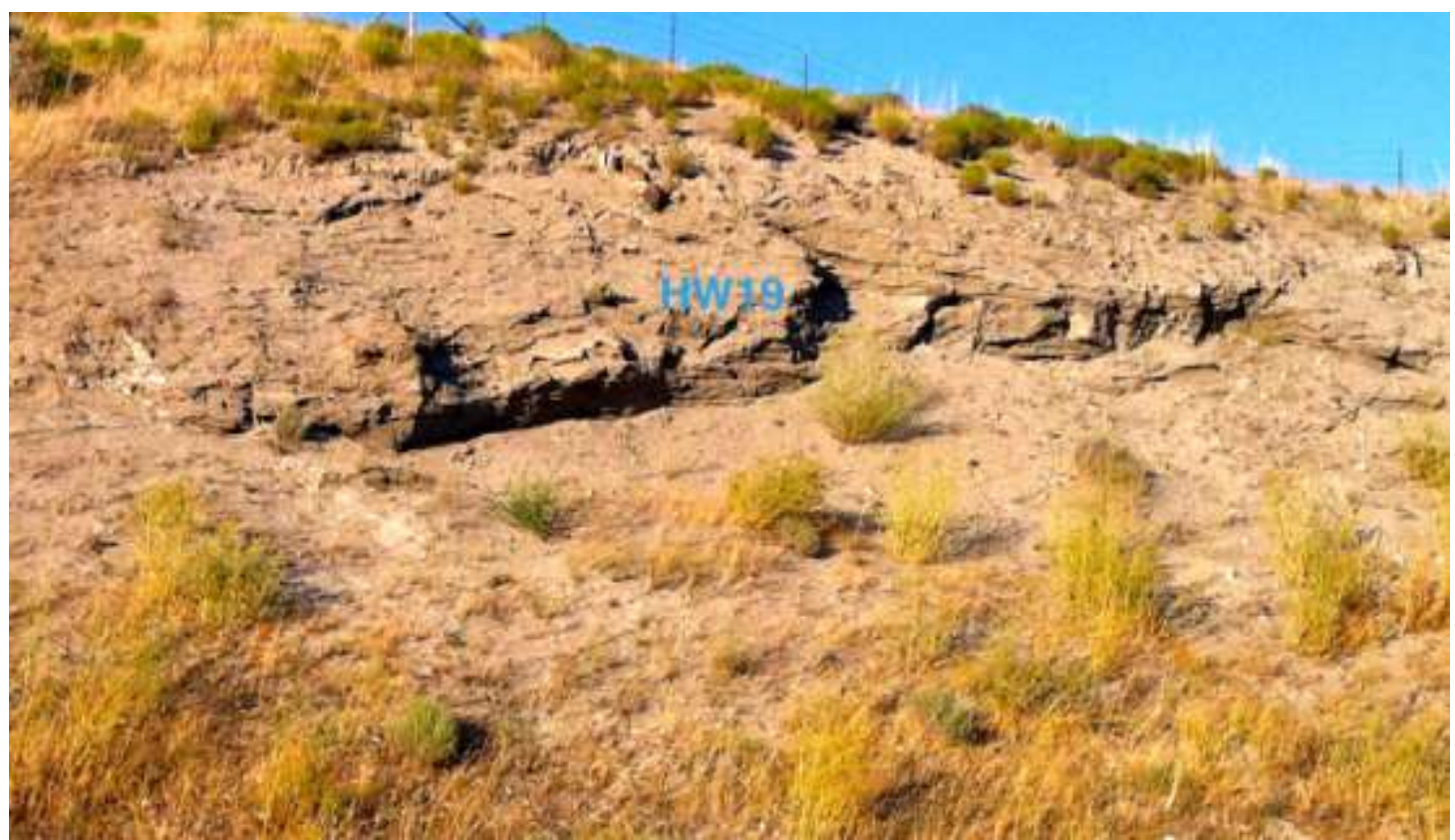

Figure 20 Arlington roadcut with sample location labeled.

The Arlington roadcut is located at milepost 1 along Highway 19 south of downtown Arlington, Oregon (Figure 19). The GPS coordinates for this site are N 45.71229237 latitude and W -120.1921135 longitude; the elevation is $164 \mathrm{~m}$. The roadcut contains Missoula Flood sediments. The sample collected, HW19 (Figure 20), contains $2.0 \% \pm 0.1 \mathrm{CaCO}_{3}$ (Table 6).

Table 6 Chittick results for Arlington site.

\begin{tabular}{|c|c|c|}
\hline Sample ID & $\begin{array}{c}\text { Average } \mathrm{CaCO}_{3} \\
\text { Percent }\end{array}$ & $\begin{array}{c}\text { Stage of } \\
\text { Development }\end{array}$ \\
\hline $\begin{array}{l}\text { HW19 Missoula Flood } \\
\text { gravels }\end{array}$ & $2.0 \pm 0.1$ & Stage I \\
\hline
\end{tabular}




\subsection{Loess Sites}

\subsubsection{Washtucna (Washtucna, Washington)}

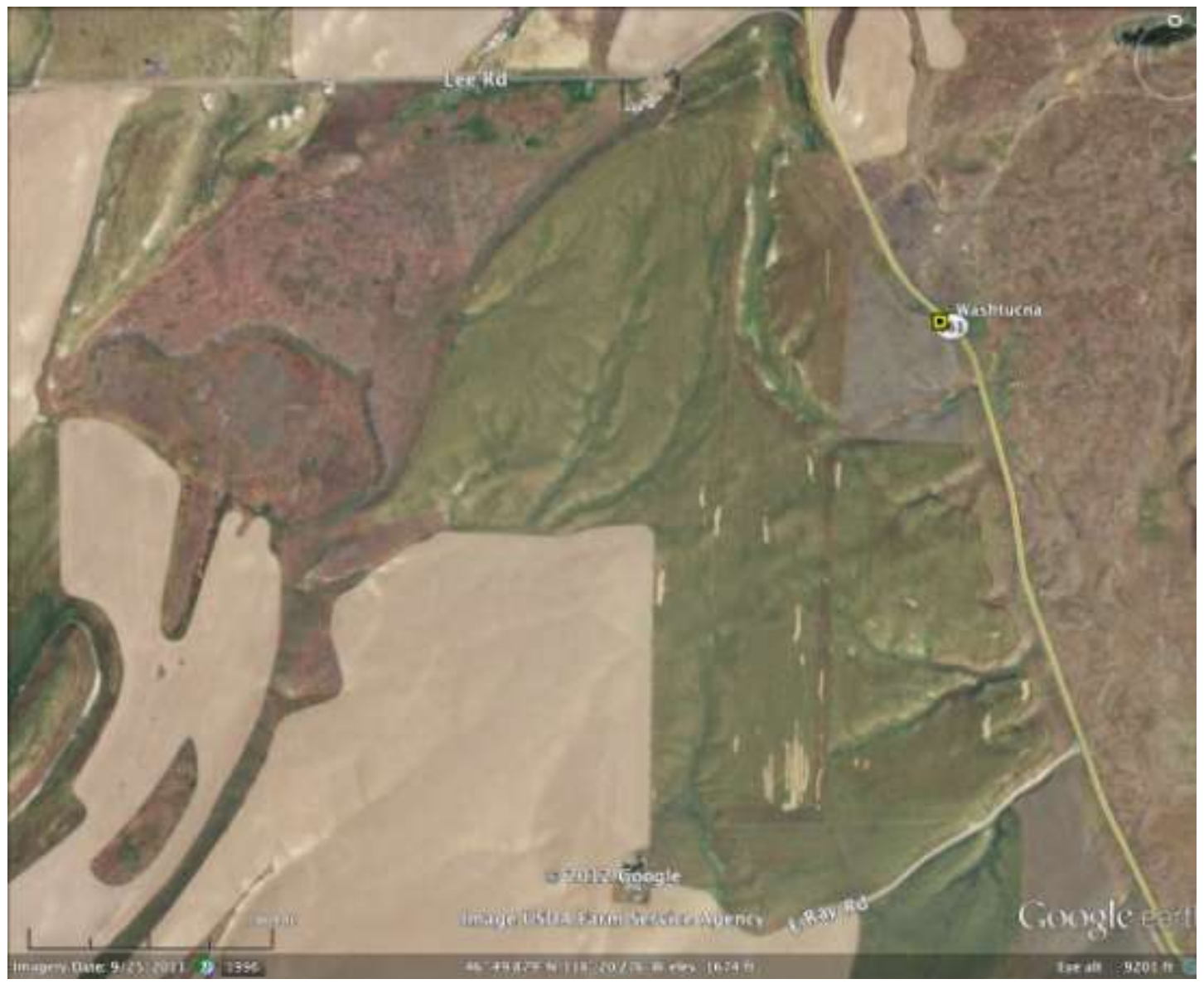

Figure 21 Location of the Washtucna field site near Washtucna, Washington.

The Washtucna outcrop is located $6.4 \mathrm{~km}$ northwest of Washtucna, Washington along SR 261 (Figure 21). The GPS coordinates for this site are N 46.834753 latitude and W -118.328585 longitude; the elevation is $501 \mathrm{~m}$. Two samples were taken from two loess layers. 


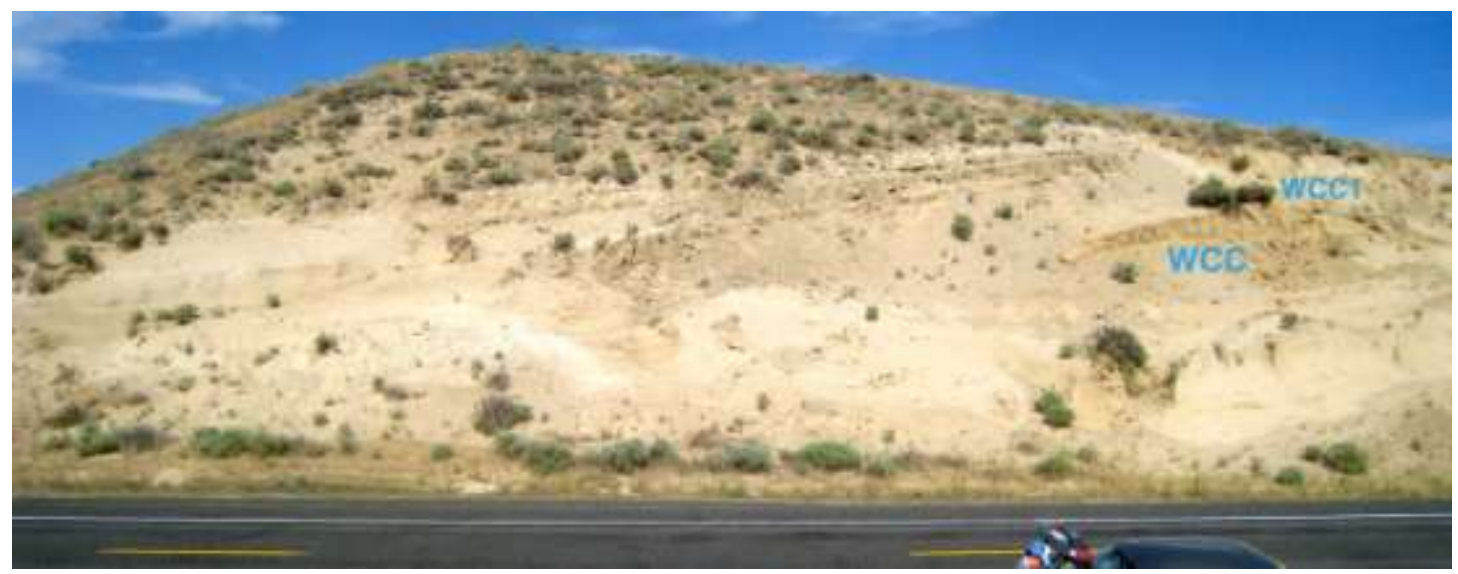

Figure 22 Washtucna outcrop with sample locations labeled.

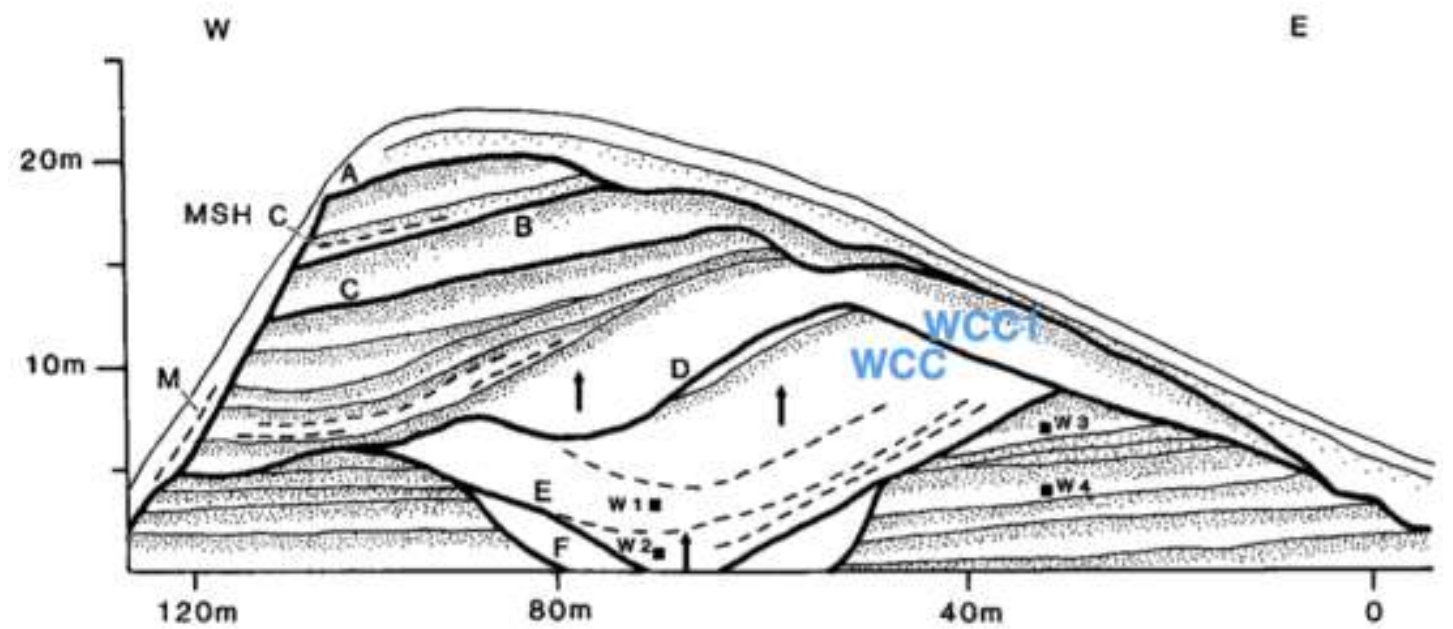

Figure 23 Washtucna stratigraphy, "Line-and stipple pattern marks approximate position of prominent paleosol $B$ horizons. Dashed lines are tephras; those correlated are : M=Mazama; MSH S=Mount St. Helens set S; MSH C= Mount St. Helens set C. Heavy lines are flood-cut unconformities and are labeled alphabetically" (McDonald and Busacca, 1988a).

The Washtucna field site is the most famous loess stratigraphy site in eastern Washington (Figure 22) and has been interpreted by many previous workers including: McDonald and Busacca (1988a), Baker et al. (1991), Bjornstad et al. (2001), and Bjornstad (2006). There are a total of five angular unconformities and one disconformity in the section (McDonald and Busacca, 1988a). The outcrop is interpreted as predominately loess deposits separated by unconformities and 
paleosols (Figure 23). There are also tephra layers, two of which have been dated, both of which overlie the sampled layers (Figure 23). The youngest, Mount St. Helen's "S" is 15,500 calendar years old and fell during the Missoula Flood times. The oldest is the Mount St. Helens set C ash dated at approximately $36 \mathrm{ka}$. The unconformities cut below the "S" ash were produced at the times of floods older than the Missoula Floods.

There are no flood deposits present at the site, but the presence of loess cut by unconformities is evidence for earlier flooding events. McDonald and Busacca (1988a) interpret that each unconformity was caused by flood scouring and count four episodes of floods older than $36 \mathrm{ka}$. The calcrete paleosols at the tops of the loess sequences are evidence for time in between the deposits. The surfaces are all irregular because deposition occurred on flood-scoured sequences. Two samples were taken, WCC and WCC1 (Figure 22), near the top of two loess layers. Sample WCC measures $4.08 \pm 0.16$ percent $\mathrm{CaCO}_{3}$ and WCC1 measures $9.55 \pm 0.20$ percent; both are Stage II in calcrete development (Table 7). The WCC1 loess layer was tested for particle size analysis and contains $13.3 \%$ sand, $82.8 \%$ silt, and $3.9 \%$ clay. The sand contains quartz.

The floods that cut unconformities below the ash are at least 36,000 years old. The calcrete formation on loess layers between the unconformities provides evidence for at least 20,000 years between flood scouring events. There is evidence for four floods, probably all Middle Pleistocene. 
Table 7 Chittick results for Washtucna field site.

\begin{tabular}{|c|cc|}
\hline Sample ID & $\begin{array}{c}\text { Average } \mathrm{CaCO}_{3} \\
\text { Percent }\end{array}$ & $\begin{array}{c}\text { Stage of } \\
\text { Development }\end{array}$ \\
\hline WCC loess & $4.08 \pm 0.16$ & Stage II \\
\hline $\begin{array}{c}\text { WCC1 calcrete in } \\
\text { loess }\end{array}$ & $9.55 \pm 0.20$ & Stage II \\
\hline
\end{tabular}

\subsubsection{Benge (Benge, Washington)}

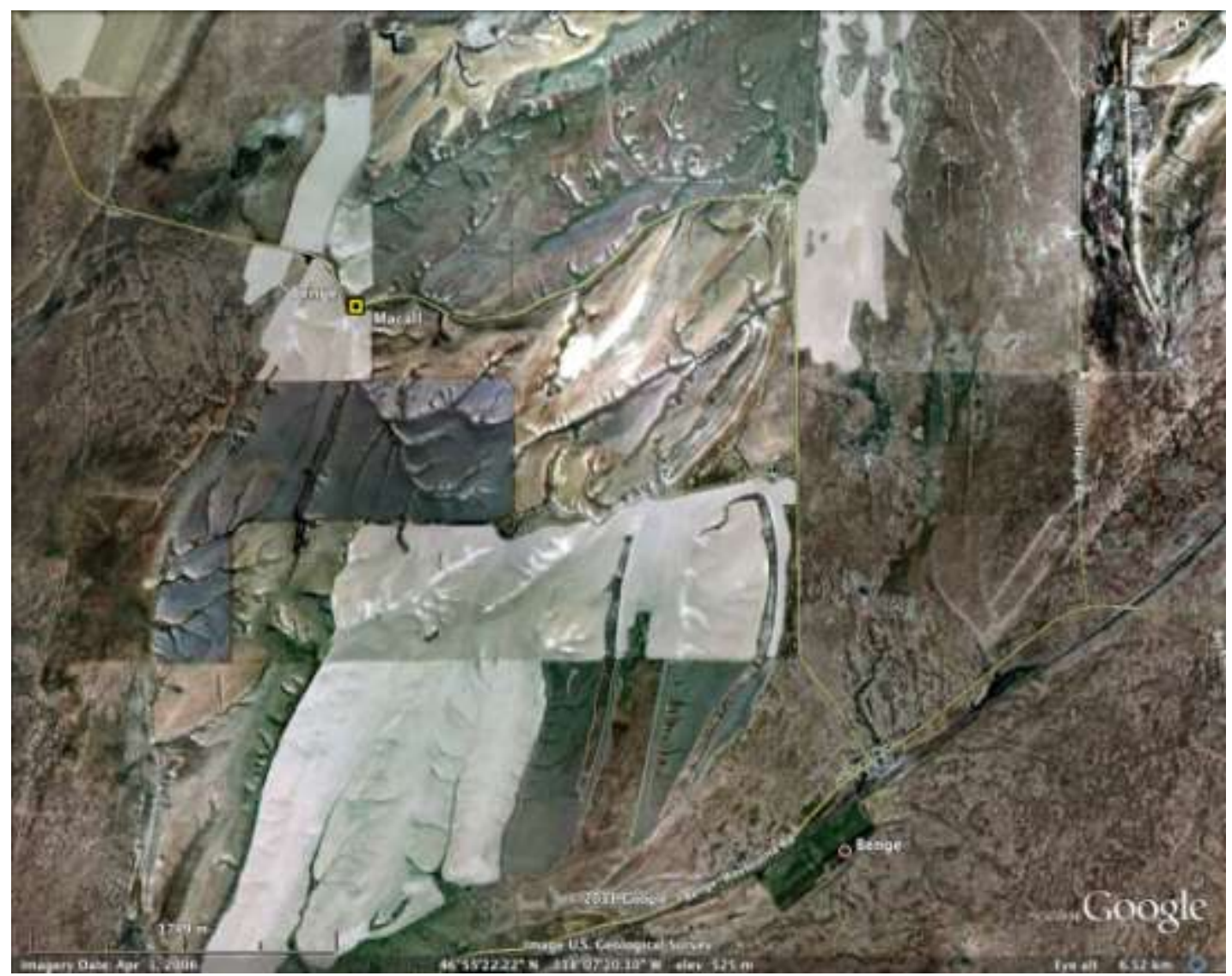

Figure 24 Location of the Benge field site.

The Benge site is located $6 \mathrm{~km}$ from Benge, Washington along the Benge-

Ralston Road (Figure 24) The GPS coordinates for this site are N 46.9324525

latitude and W -118.14205 longitude; the elevation is $506.6 \mathrm{~m}$. Four flood-cut

unconformities are present with three calcrete paleosols (Figure 25) (McDonald and 
Busacca, 1988a). Samples B1 and B2 are in the lowermost paleosol, capped by a calcrete horizon, B3. The calcrete horizon along B3 is the lowermost unconformity at the site. B1 was taken from the reddish Bt soil horizon, B2 is taken from the B horizon. Sample B4 was taken from the B horizon that is capped by another thin calcrete layer. The sediments from B4A that overlie the lowest unconformity, B4, have reversed magnetic polarity (Baker et al., 1991), representing at least one Early Pleistocene flood. No flood gravels are present at the site, but McDonald and Busacca (1988a) interpret layers B1-B4A as old loesses associated unconformities cut by floods.

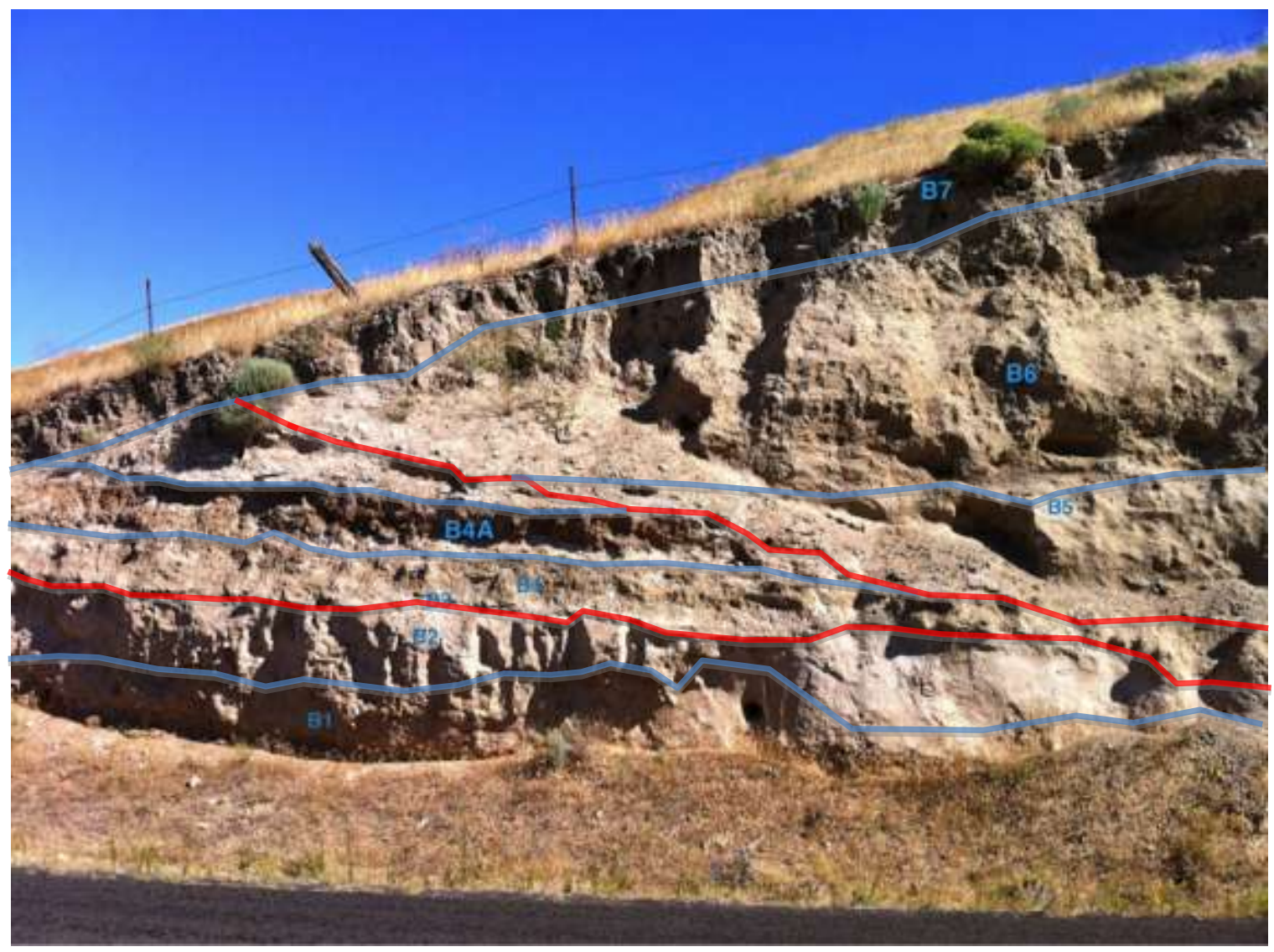

Figure 25 Benge Outcrop with sample locations labeled B1-B5. 


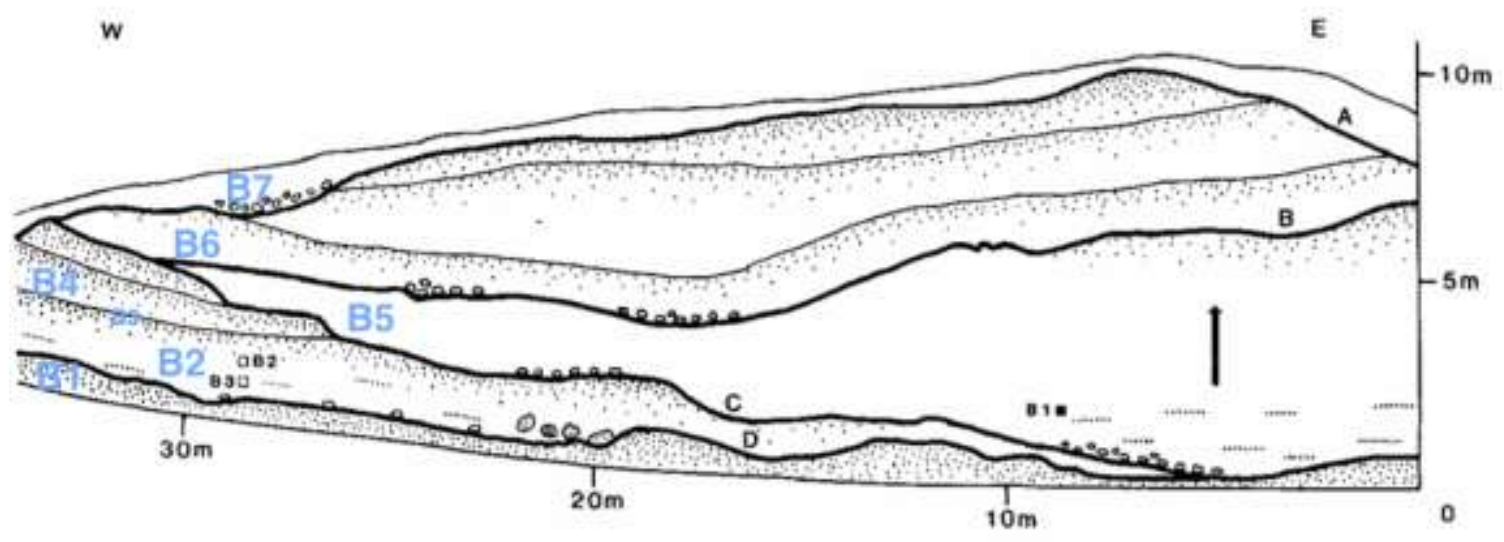

Figure 26 Benge stratigraphy, "Line-and stipple pattern marks approximate position of prominent paleosol B horizons. Dashed lines are tephras; those correlated are : M=Mazama; MSH S=Mount St. Helens set S; MSH C= Mount St. Helens set C. Heavy lines are flood-cut unconformities and are labeled alphabetically" (McDonald and Busacca, 1988a).

All of these older paleosols are truncated by a loess deposit B5 with normal magnetic polarity interpreted as Late Wisconsin (McDonald and Busacca, 1988a). Another Missoula Flood age loess deposit, B6, overlies B5, with a layer modern soil development, B7, covering the outcrop.

The amount of $\mathrm{CaCO}_{3}$ in the paleosols (Table 8) and flood-cut unconformities provide evidence for large amounts between each paleosol, at least 20,000 years. B1-B3 have 10.9-13.9\% $\mathrm{CaCO}_{3}$ and Stage II - II+ calcrete development. They are interpreted as Early Pleistocene in age. B4, in the B soil horizon of the overlying paleosol, contains 3 percent $\mathrm{CaCO}_{3}$. It is probably Middle Pleistocene in age, as interpreted by Bjornstad et al. (2001). The large, approximately $10 \mathrm{~m}$ thick, loess deposit $\mathrm{B} 5$ contains less than one percent $\mathrm{CaCO}_{3}$ and is Late Wisconsin in age. Another loess deposit (not sampled), B6, also Late Wisconsin, overlies B5. 
Table 8 Chittick results for Benge site.

\begin{tabular}{|l|cc|}
\multicolumn{1}{c|}{ Sample ID } & $\begin{array}{c}\text { Average } \mathrm{CaCO}_{3} \\
\text { Percent }\end{array}$ & $\begin{array}{c}\text { Stage of } \\
\text { Development }\end{array}$ \\
\hline B1 calcrete in loess & $13.3 \pm 1.0$ & Stage II+ \\
\hline B2 calcrete in loess & $10.9 \pm 0.3$ & Stage II \\
\hline $\begin{array}{l}\text { B3 calcrete paleosol } \\
\text { in loess }\end{array}$ & $13.9 \pm 0.4$ & Stage II+ \\
\hline B4 loess & $3.1 \pm 0.1$ & Stage II \\
\hline B5 loess & $0.8 \pm 0.1$ & Stage I \\
\hline
\end{tabular}

\subsubsection{E. Callaway Road (Benge, Washington)}

The Calloway Road outcrop is located along E Calloway Road 0.7 km east of the E Calloway Road and the Ritzville-Benge Road intersection (Figure 27) The GPS coordinates for this site are $\mathrm{N} 46.98671$ latitude and $\mathrm{W}-118.078691$ longitude; the elevation is $524.9 \mathrm{~m}$. I discovered the outcrop.

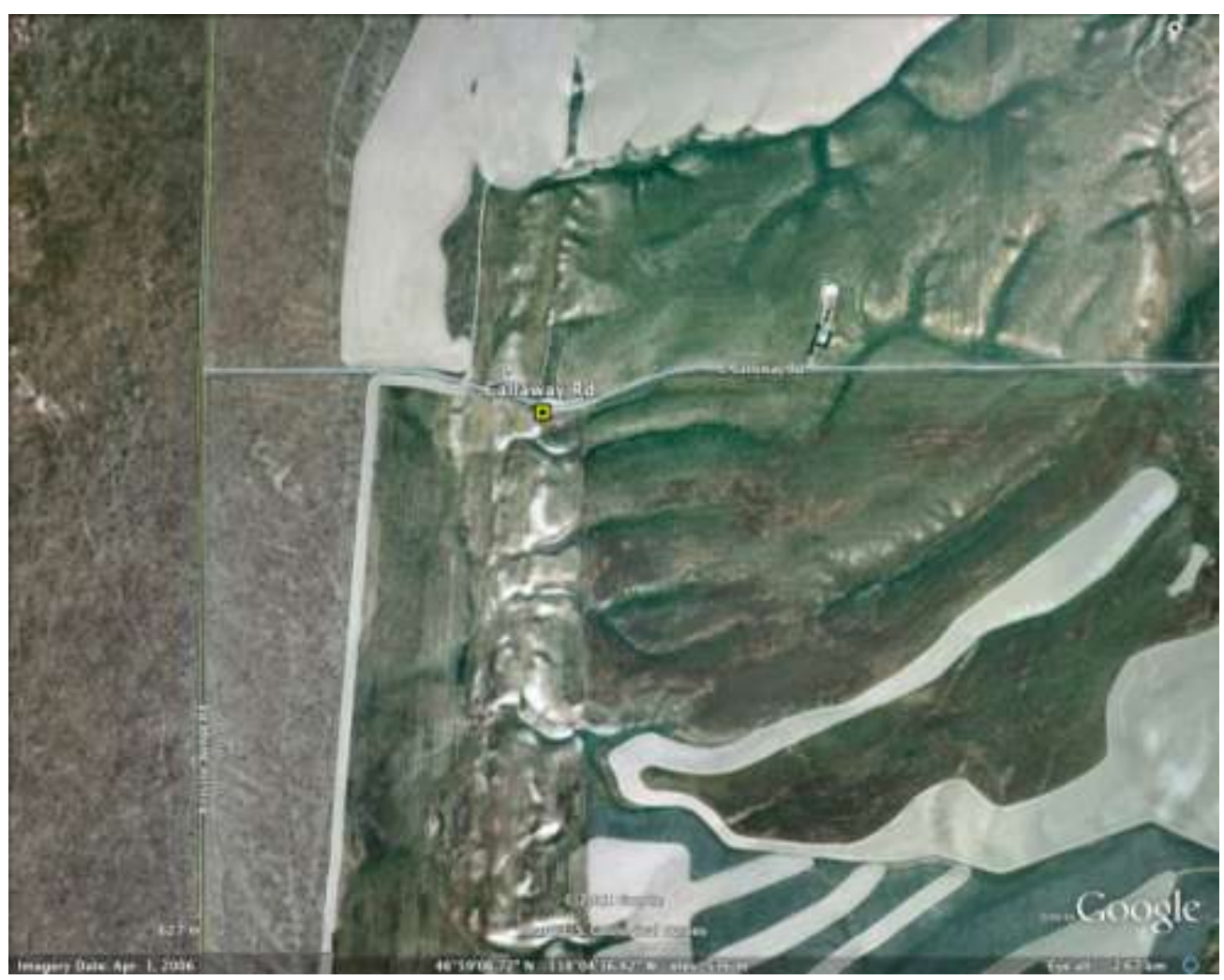

Figure 27 Location of the E. Callaway Road field site near Benge, Washington. 


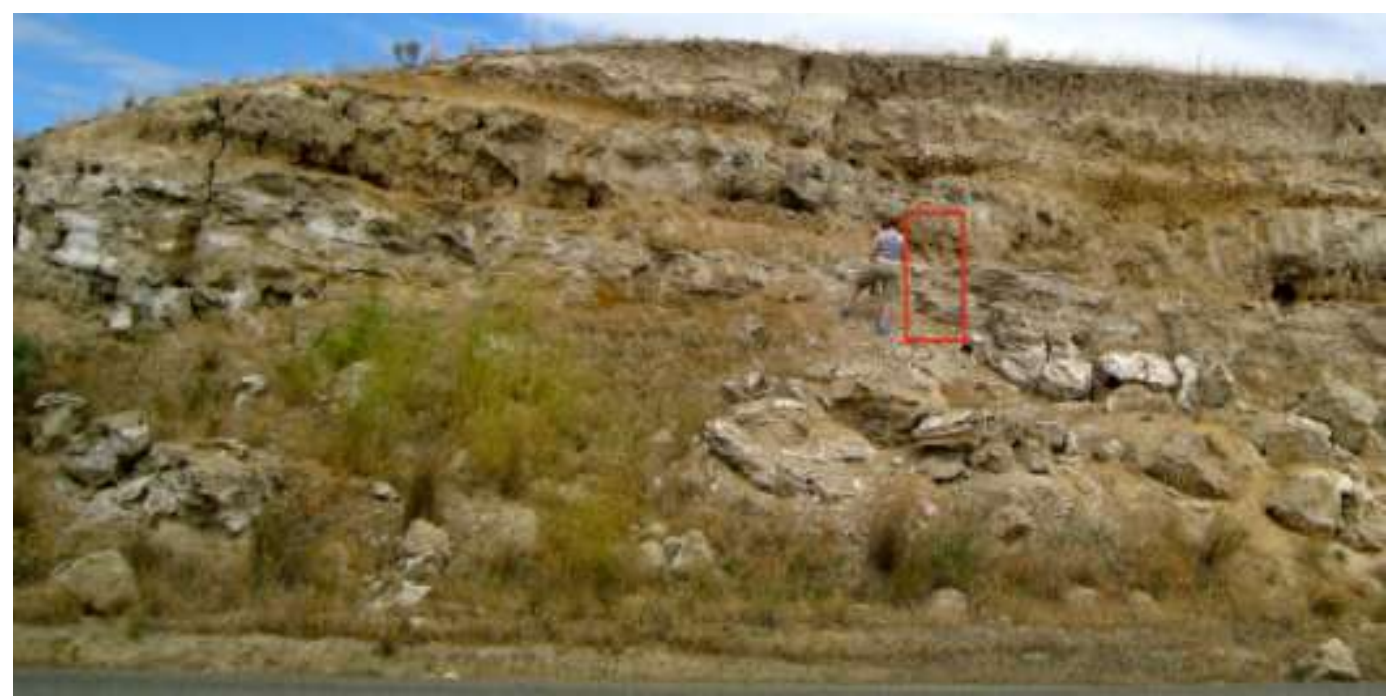

Figure 28 E. Callaway Road outcrop, the red box indicates the location of Error! Reference source not found.Error! Reference source not found..

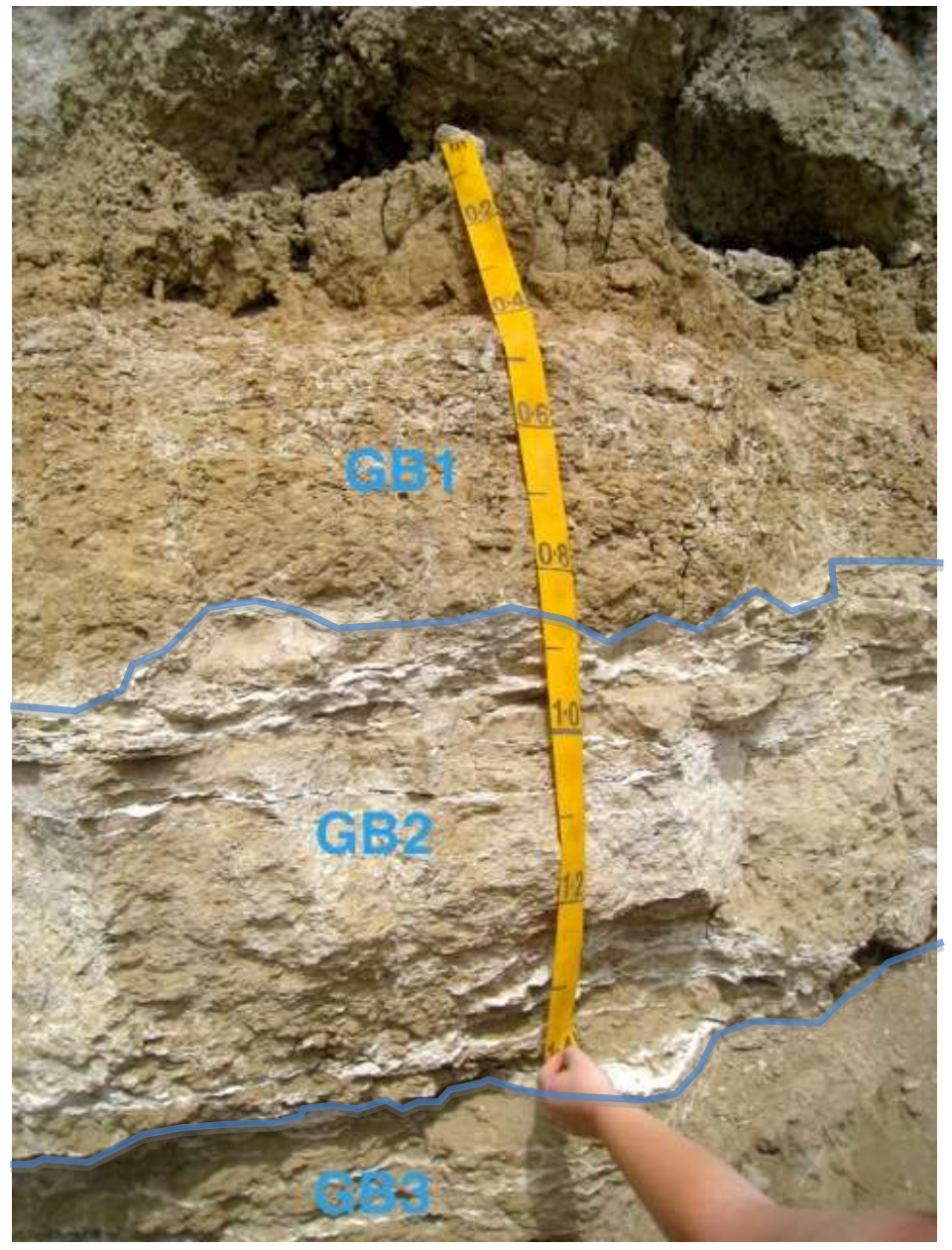

Figure 29 E. Callaway Road close-up with sample locations labeled. 


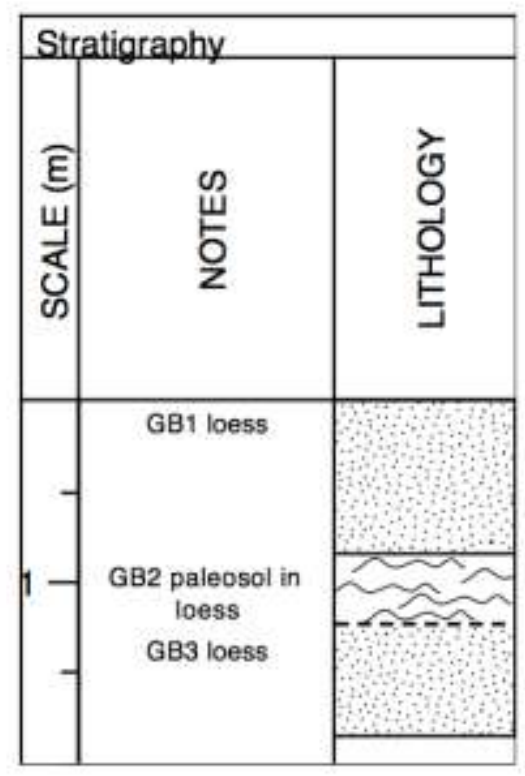

Figure 30 Stratigraphy of E. Callaway Road outcrop.

The outcrop contains layers of loess and paleosols in the loess (Figure 28). GB1 and GB3 are both layers of loess, measuring 11.1\% \pm 0.6 and $14.3 \% \pm 0.1$ $\mathrm{CaCO}_{3}$, Stage II and II+ development (Table 9). Sample GB2, another loess deposit, was collected in between the two layers of loess in a potential calcrete paleosol and measured 29.2\% $\pm 0.6 \mathrm{CaCO}_{3}$, Stage III development. No flood deposits are present, but the layers of loess with late stage $\mathrm{CaCO}_{3}$ paleosols implies that there is considerable time between the deposition events and the unconformities were probably produced by floods in the Middle Pleistocene.

Table 9 Chittick results for E. Callaway Road site.

\begin{tabular}{|l|cc|}
\hline \multicolumn{1}{|c|}{ Sample ID } & \multicolumn{1}{c|}{$\begin{array}{c}\text { Average } \mathrm{CaCO}_{3} \\
\text { Percent }\end{array}$} & $\begin{array}{c}\text { Stage of } \\
\text { Development }\end{array}$ \\
\hline GB1 loess & $11.1 \pm 0.6$ & Stage II \\
\hline $\begin{array}{l}\text { GB2 calcrete } \\
\text { paleosol in loess }\end{array}$ & $29.2 \pm 0.6$ & Stage III \\
\hline GB3 loess & $14.3 \pm 0.1$ & Stage II+ \\
\hline
\end{tabular}




\subsubsection{Rulo Outcrop (Walla Walla, Washington)}

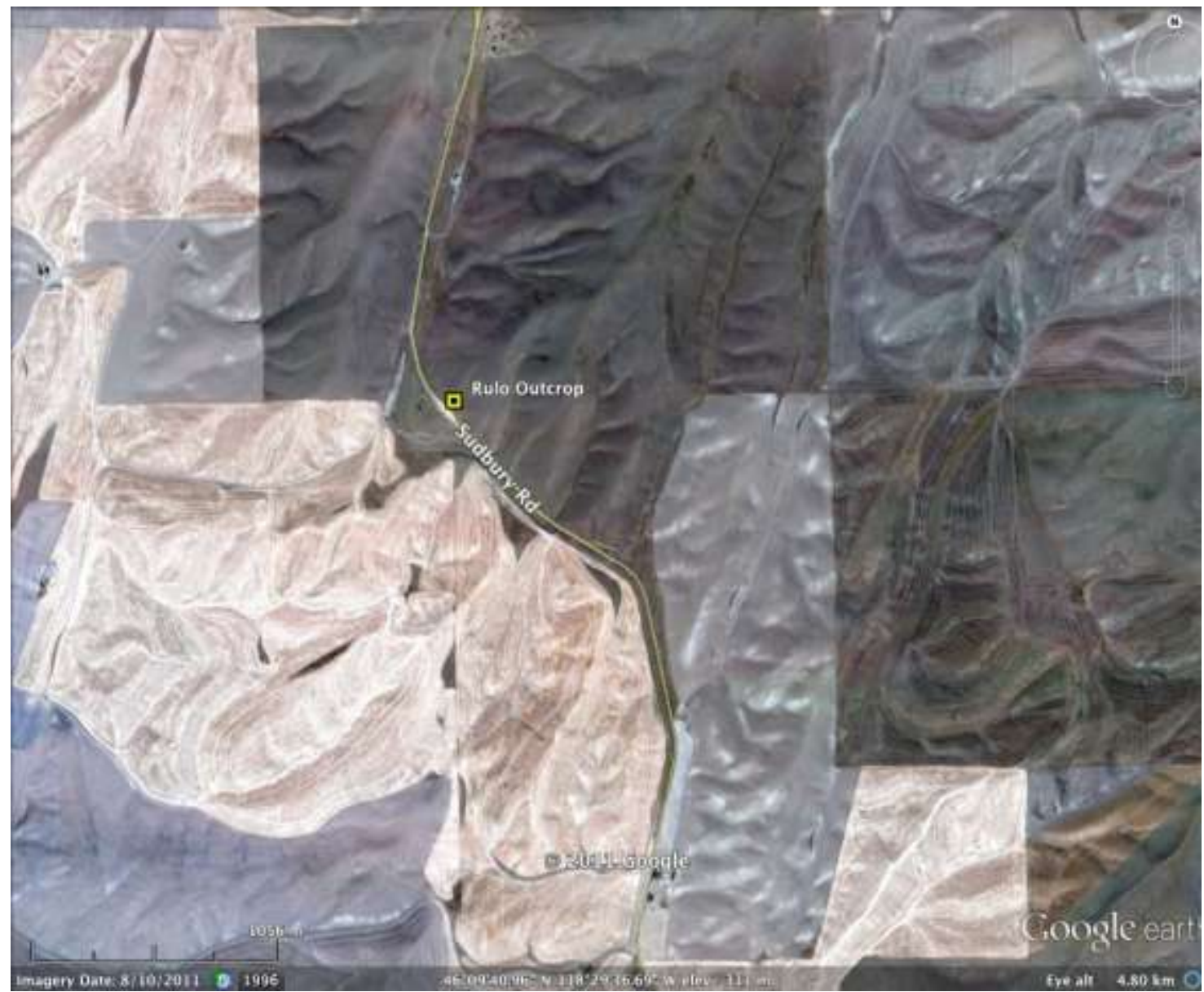

Figure 31 Location of the Rulo Outcrop field site near Walla Walla, Washington.

The Rulo outcrop was studied by Karen Gastineau (2011) at Whitman

College for an undergraduate thesis project. The outcrop is located $8 \mathrm{~km}$ northwest of Walla Walla, Washington along Sudbury Road (Figure 31). The GPS coordinates for this site are N 46.16536944 latitude and W -118.5024 longitude; the elevation is $299.9 \mathrm{~m}$. The site contains several units of silt and calcrete development (Figure 32). 


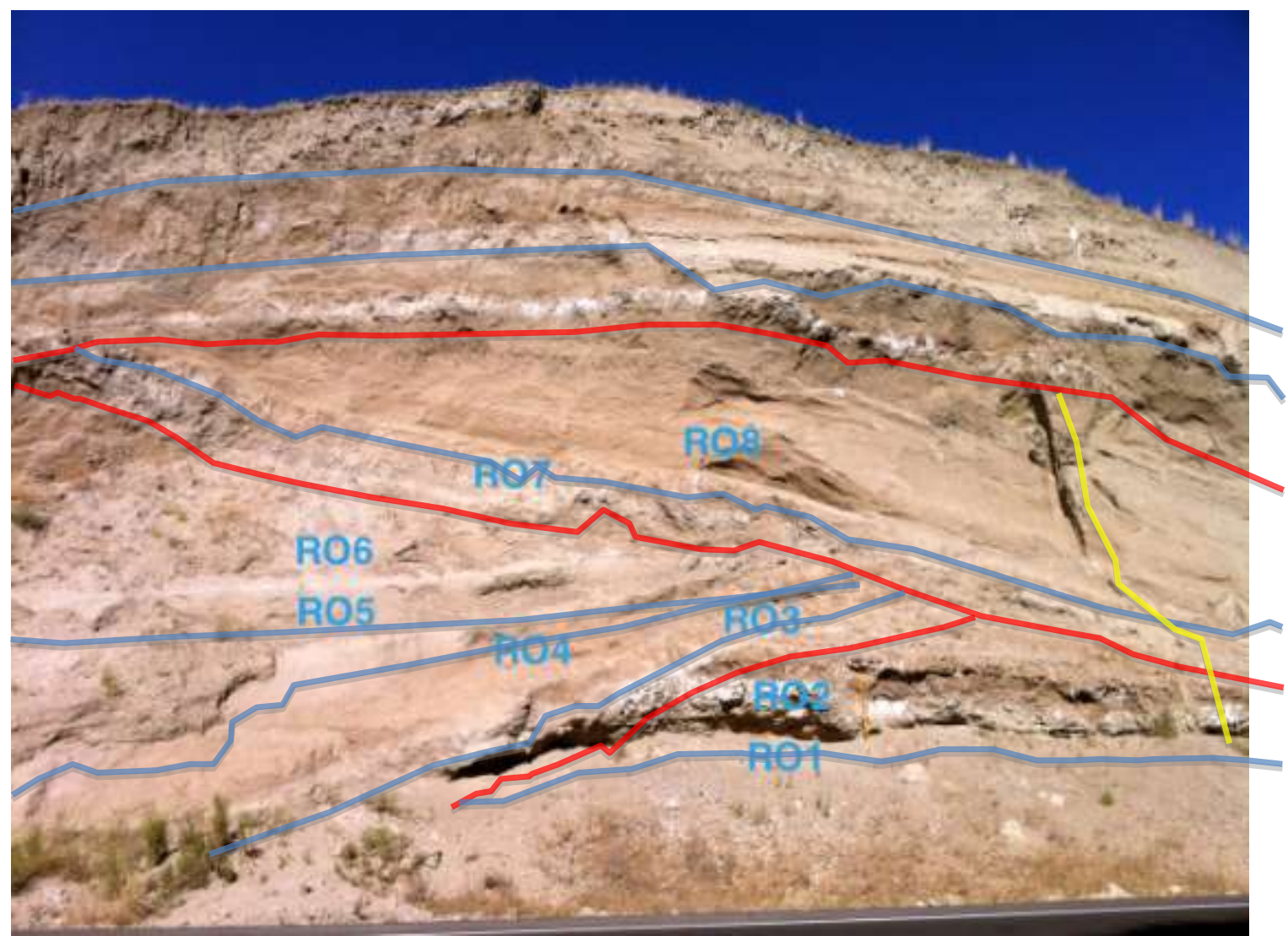

Figure 32 Rulo outcrop with sample locations labeled, red lines are unconformities and the yellow line is a clastic dike.

Layer R01 is a layer of quartz sand at the base of the section with basalt fragments and mica present in the silt to fine sand, with a few basalt pebbles (Gastineau, 2011). Sample R01 measured 5.9\% $\pm 0.2 \mathrm{CaCO}_{3}$ (Table 10). The second unit, sample R02, is truncated by two flood-cut unconformities in red (Figure 32). RO2 was taken from a rigid calcrete horizon, a Bk soil horizon below a Bt. Mica is present throughout R02, which infers either paleoflood or loess origin. Sample RO2 measured 21.7\% $\pm 0.7 \mathrm{CaCO}_{3}$, Stage III. A clastic dike, shown in yellow, also truncates these layers down to the first unit. Above the unconformity and dipping to the north, lie layers R03 through R06. Layers R03 and R04 are poorly consolidated silt layers that grade into a prominent calcrete horizon at the top (Gastineau, 2011). 
The samples measure $0.7 \% \pm 0.2 \mathrm{CaCO}_{3}$ for $\mathrm{RO} 3$ and $12.2 \% \pm 0.4$ for R04. The two layers above, R05 and R06, are structureless silt units and measure 15.3\% \pm 0.5 and $14.0 \% \pm 0.2 \mathrm{CaCO}_{3}$, Stage II+. Dipping in the north direction above the other unconformity are layers R07 and R08. Layers R07 contains at Bt over Bk soil horizons and measures $6.4 \% \pm 0.4 \mathrm{CaCO}_{3}$. Above these calcrete layers is a massive silt layer, R08, which contains two tephra layers. The two tephras are dated at 165$210 \mathrm{ka}$ and >200ka. Another unconformity lies above R08, and the top two units are made up of coarse silt with a basal unit of calcrete (Gastineau, 2011). These loess units point to evidence for at least four ancient floods that are older than $200 \mathrm{ka}$. They are probably all Middle Pleistocene in age.

Table 10 Chittick results for Rulo Outcrop site.

\begin{tabular}{|lcc|}
\multicolumn{1}{|c}{ Sample ID } & $\begin{array}{c}\text { Average } \mathrm{CaCO}_{3} \\
\text { Percent }\end{array}$ & $\begin{array}{c}\text { Stage of } \\
\text { Development }\end{array}$ \\
\hline RO1 flood gravels & $5.9 \pm 0.2$ & Stage II \\
\hline $\begin{array}{l}\text { RO2 calcrete paleosol } \\
\text { in loess }\end{array}$ & $21.7 \pm 0.7$ & Stage III \\
\hline RO3 loess & $0.7 \pm 0.2$ & Stage I \\
\hline $\begin{array}{l}\text { RO4 calcrete paleosol } \\
\text { in loess }\end{array}$ & $12.2 \pm 0.4$ & Stage II+ \\
\hline $\begin{array}{l}\text { RO5 calcrete paleosol } \\
\text { in loess }\end{array}$ & $15.3 \pm 0.5$ & Stage II+ \\
\hline $\begin{array}{l}\text { RO6 calcrete paleosol } \\
\text { in loess }\end{array}$ & $14.0 \pm 0.2$ & Stage II+ \\
\hline $\begin{array}{l}\text { RO7 calcrete paleosol } \\
\text { in loess }\end{array}$ & $6.4 \pm 0.4$ & Stage II \\
\hline $\begin{array}{l}\text { RO8 calcrete paleosol } \\
\text { in loess }\end{array}$ & $4.9 \pm 0.1$ & Stage II \\
\hline
\end{tabular}




\subsection{Flood deposits}

\subsubsection{Poplar Heights (Highland, Washington)}

Poplar Heights is located along E $45^{\text {th }}$ Avenue approximately 240 meters west of South Oak St., Highland, in the Pasco Basin (Figure 33). The Global Positioning System (GPS) coordinates for this site are N 46.168759 latitude and W 119.09852 longitude; the elevation is $44.5 \mathrm{~m}$. Stratigraphic layers are described (Figure 34), and each was sampled.

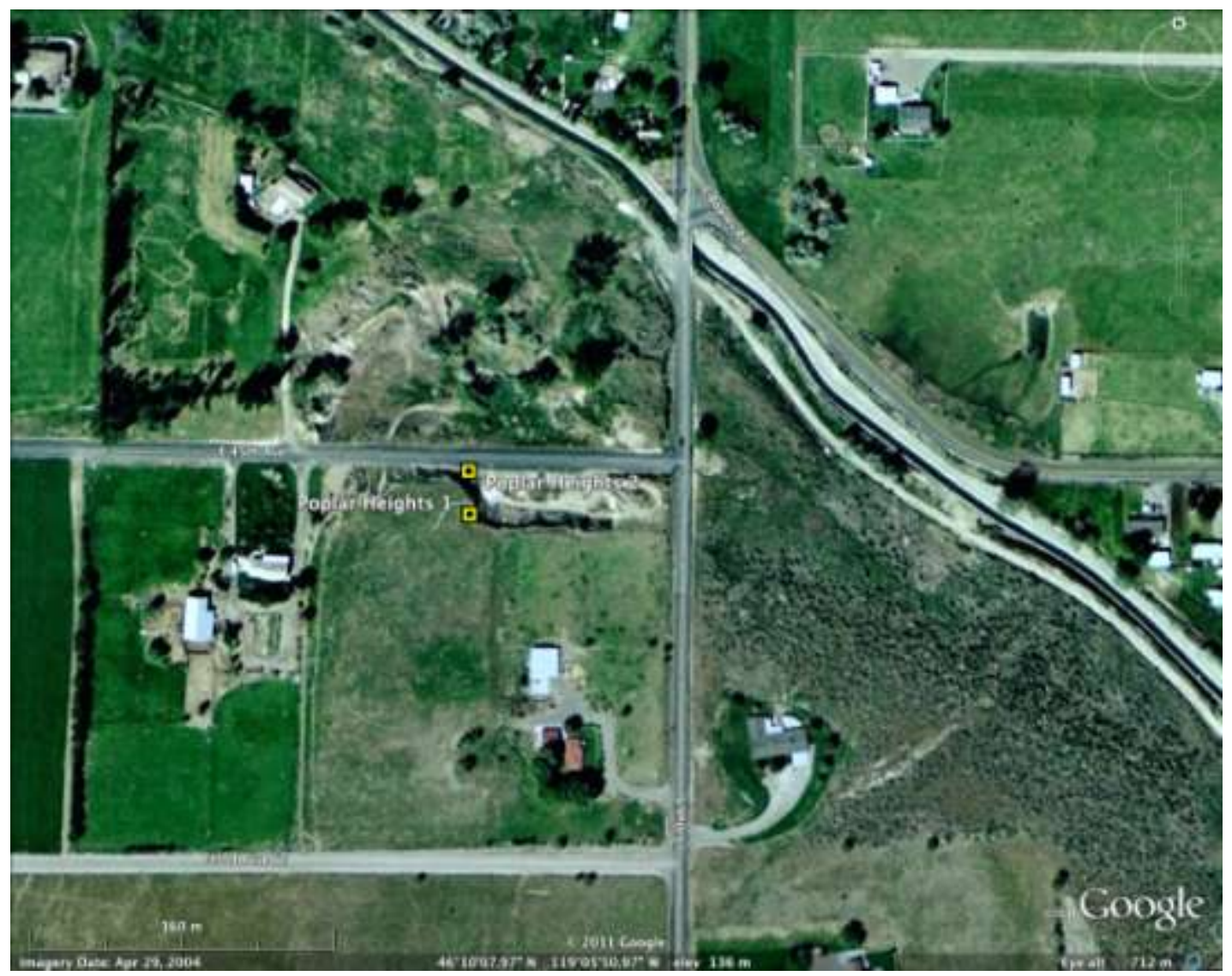

Figure 33 Location of Poplar Heights field site in Highland, Washington.

PH1 is from the lowest layer, the gravel-dominated flood deposit. Baker et al. (1991) measured reversed magnetic polarity in a sand lens in this gravel deposit, dating the flood deposit to Early Pleistocene. Figure 36 shows a close-up of the PH1 
flood deposit which contains exotic, non-basalt, clasts of granites, quartzites, and some schists. Sample PH2 was taken from the overlying calcrete paleosol which formed in the same sediments of $\mathrm{PH} 1$. The paleosol contains $32.4 \% \pm 4.6 \mathrm{CaCO}_{3}$, Stage III development (Table 11). The third sample, PH3, was taken above an unconformity in Missoula Flood sediments (Baker et al., 1991). Based on the presence of exotic clasts, reversed magnetic polarity, and Stage III calcrete development in the paleosol, the underlying flood deposit PH1 is at least Early Pleistocene in age.

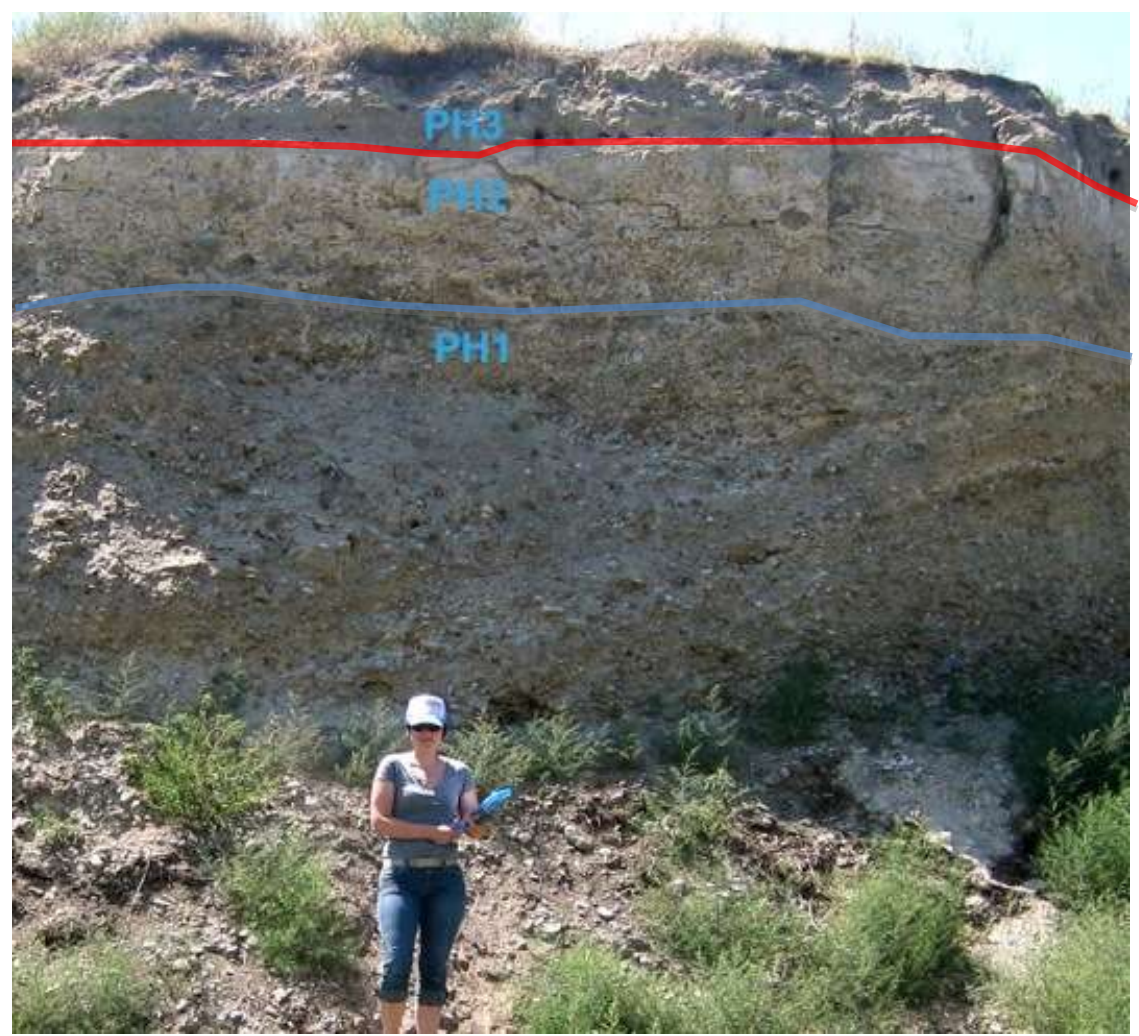

Figure 34 Poplar Heights outcrop with sample locations labeled. 


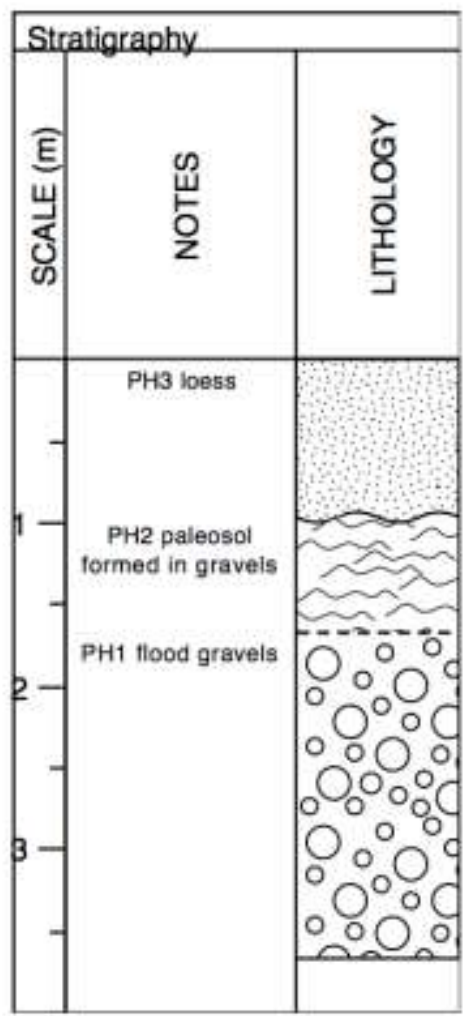

Figure 35 Stratigraphy of Poplar Heights outcrop.

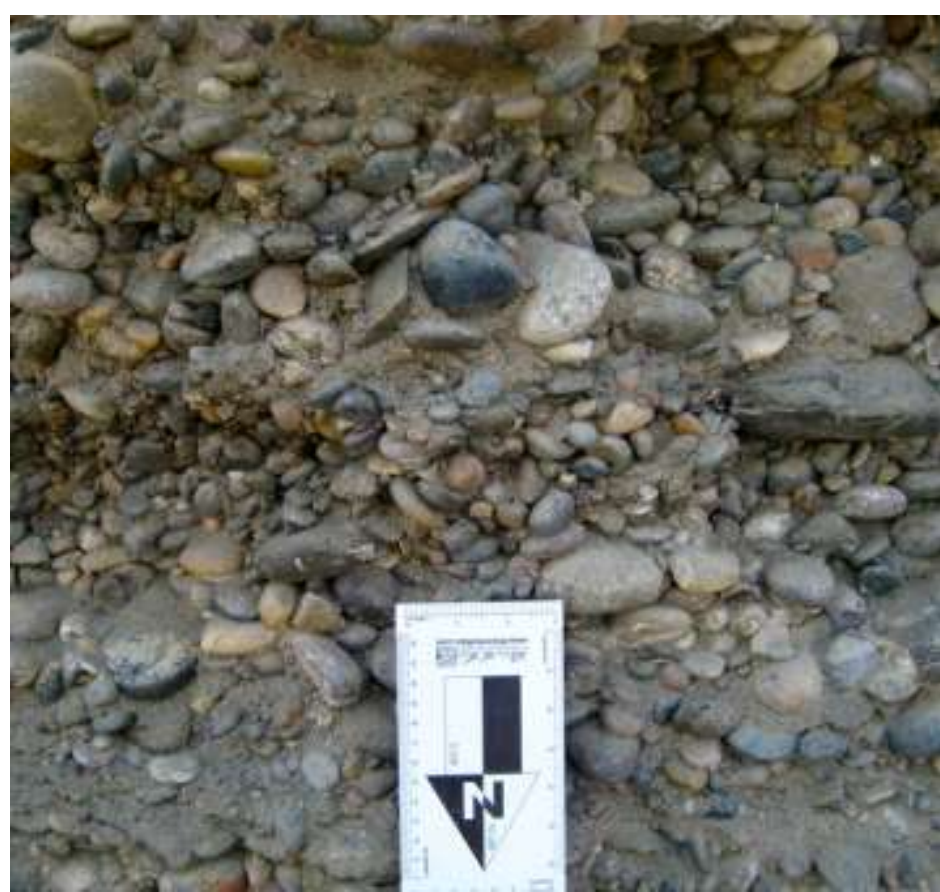

Figure 36 Close-up on exotic clasts present in the gravel-dominated PH1 flood deposit at Poplar Heights. 
Table 11 Chittick results for Poplar Heights site.

\begin{tabular}{|lcc|}
\multicolumn{1}{|c}{ Sample ID } & $\begin{array}{c}\text { Average } \mathrm{CaCO}_{3} \\
\text { Percent }\end{array}$ & Stage of Development \\
\hline $\mathrm{PH} 1$ flood gravels & $0.1 \pm 0.3$ & Stage I \\
\hline $\begin{array}{l}\mathrm{PH} 2 \text { calcrete paleosol in } \\
\text { flood gravels }\end{array}$ & $32.4 \pm 4.6$ & Stage III \\
\hline $\begin{array}{l}\text { PH3 Missoula Flood } \\
\text { sediments }\end{array}$ & $3.5 \pm 0.4$ & Stage II \\
\hline
\end{tabular}

\subsubsection{Old Maid Coulee (Mesa, Washington)}

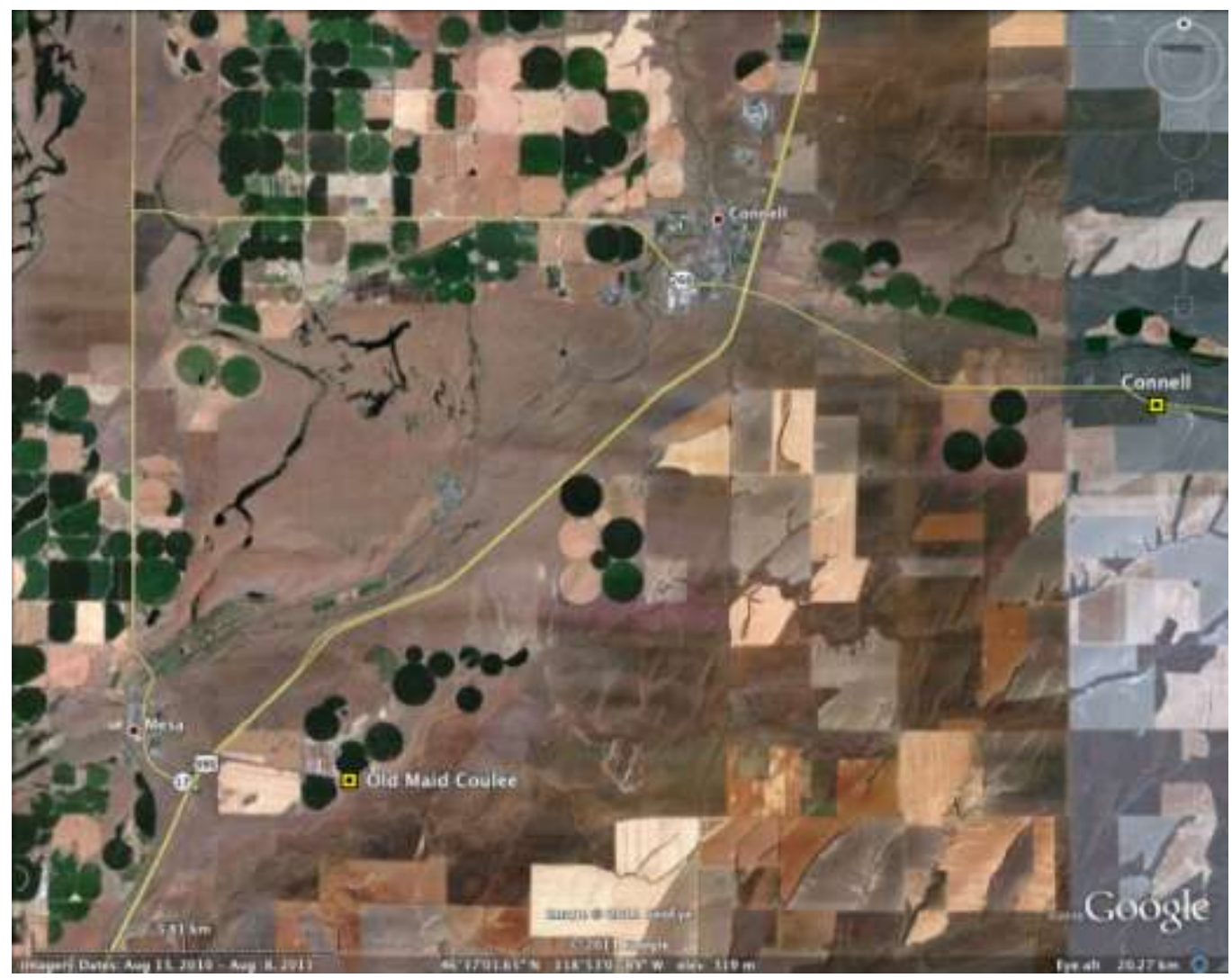

Figure 37 Location of Old Maid Coulee field site near Mesa, Washington.

Old Maid Coulee is located $4.3 \mathrm{~km}$ east of Mesa, Washington and U.S. 395

along Pepiot Road (Figure 37, 14). The GPS coordinates for this site are N 46.568056 latitude and W -118.952637 longitude; the elevation is $277 \mathrm{~m}$. Two stratigraphic 
layers are present at this site; a younger loess (OM1) over a calcrete formed in flood gravels (OM2) (Figure 39).

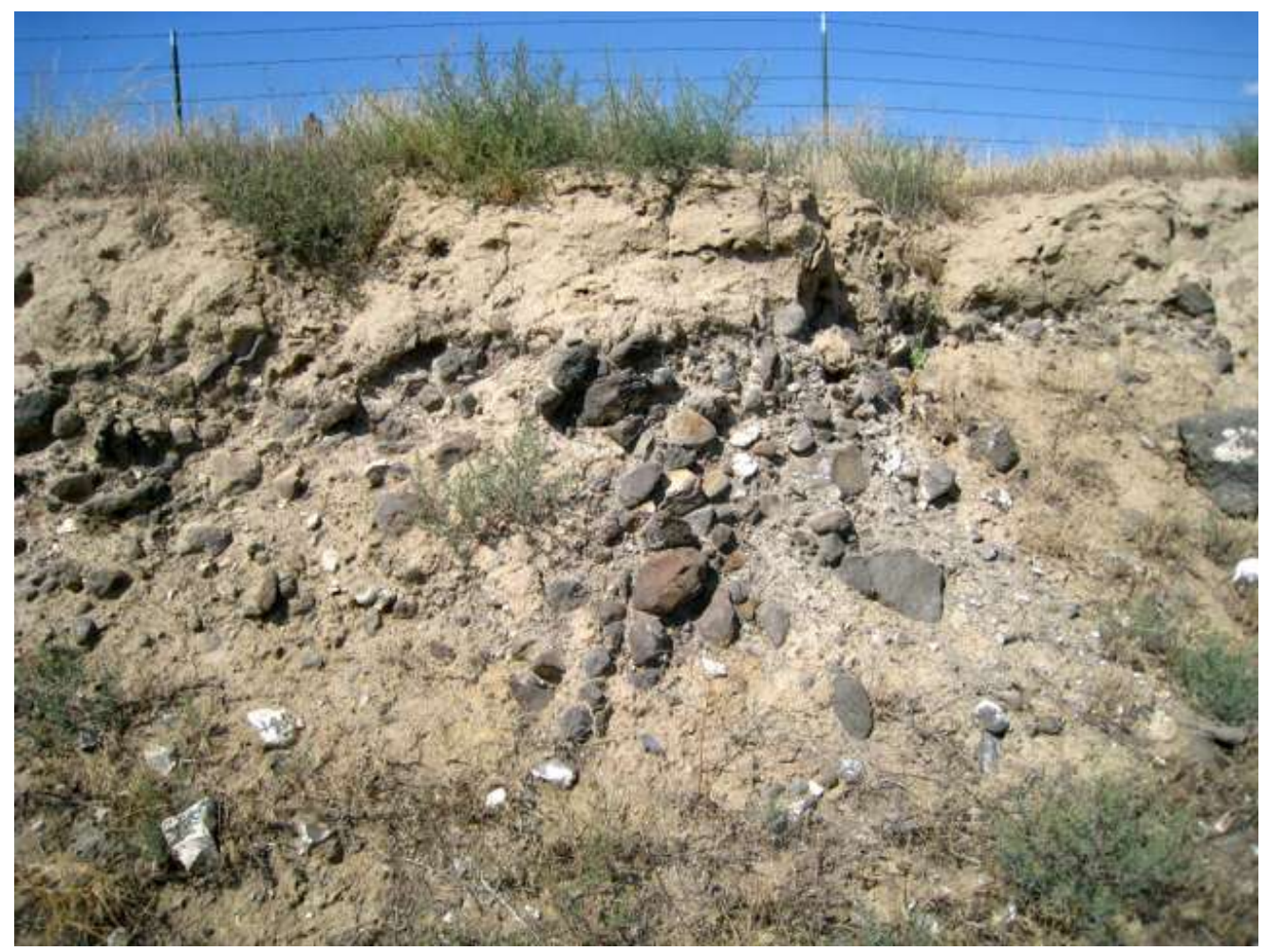

Figure 38 Old Maid Coulee outcrop.

The Old Maid Coulee site has been visited and interpreted by many other workers including: Baker (1973), Baker and Nummedal (1978), Baker et al. (1991), Patton and Baker (1978), Bjornstad et al. (2001), and Bjornstad (2006). All workers interpreted one Early Pleistocene flood deposit at the site. The Ancient Cataclysmic Flood deposit OM2 consists of highly weathered basalt and scoria clasts cemented by $\mathrm{CaCO}_{3}$. Bjornstad (2006) has reported, “...reversed magnetic polarity has been measured in the fine-grained loess just above the flood gravels and below the caliche." 


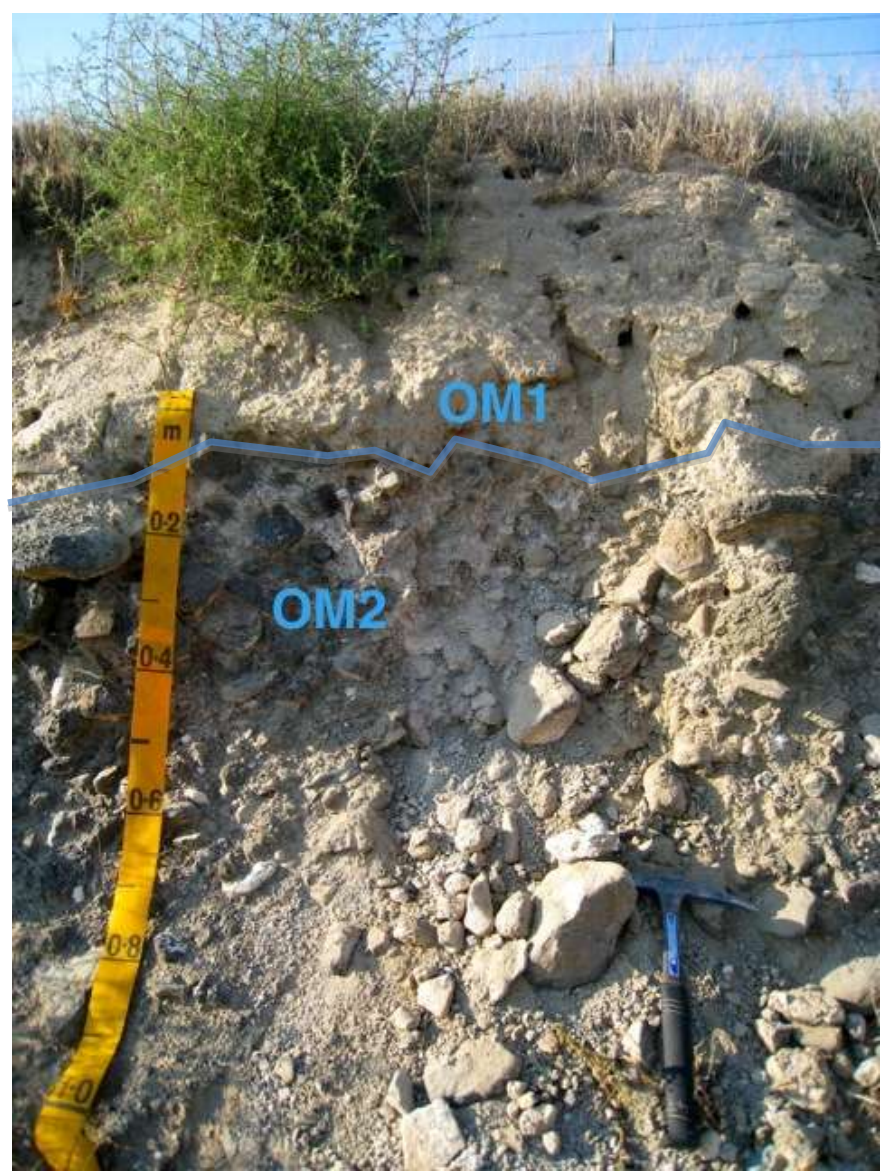

\section{Figure 39 old Maid Coulee outcrop with sample locations labeled.}

The top of the outcrop has been removed since Bjornstad (2006) last visited

the site, and therefore there is no longer a calcrete paleosol present above the loess.

However, the remaining loess above the flood gravels does not appear to be re-

worked and contains $1.2 \% \pm 0.4 \mathrm{CaCO}_{3}$ (Table 12). The flood gravels, $\mathrm{OM} 2$, are

continuously coated with $\mathrm{CaCO}_{3}$ with some cementation between clasts, placing the

gravels in at least Stage II carbonate morphology (Machette, 1985). The flood

deposit contains $4.3 \% \pm 0.9$ percent $\mathrm{CaCO}_{3}$, Stage II calcrete development, and is 
interpreted as Early Pleistocene in age based on reversed magnetic polarity. Layer

OM1 is interpreted as loess deposited since Missoula Flood times.

Table 12 Chittick results for Old Maid Coulee site.

\begin{tabular}{|lcc|}
\multicolumn{1}{c}{ Sample ID } & $\begin{array}{c}\text { Average } \mathrm{CaCO}_{3} \\
\text { Percent }\end{array}$ & $\begin{array}{c}\text { Stage of } \\
\text { Development }\end{array}$ \\
\hline OM1 loess & $1.2 \pm 0.4$ & Stage I \\
\hline OM2 flood gravels & $4.3 \pm 0.9$ & Stage II \\
\hline
\end{tabular}

\subsubsection{Potholes Coulee (George, Washington)}

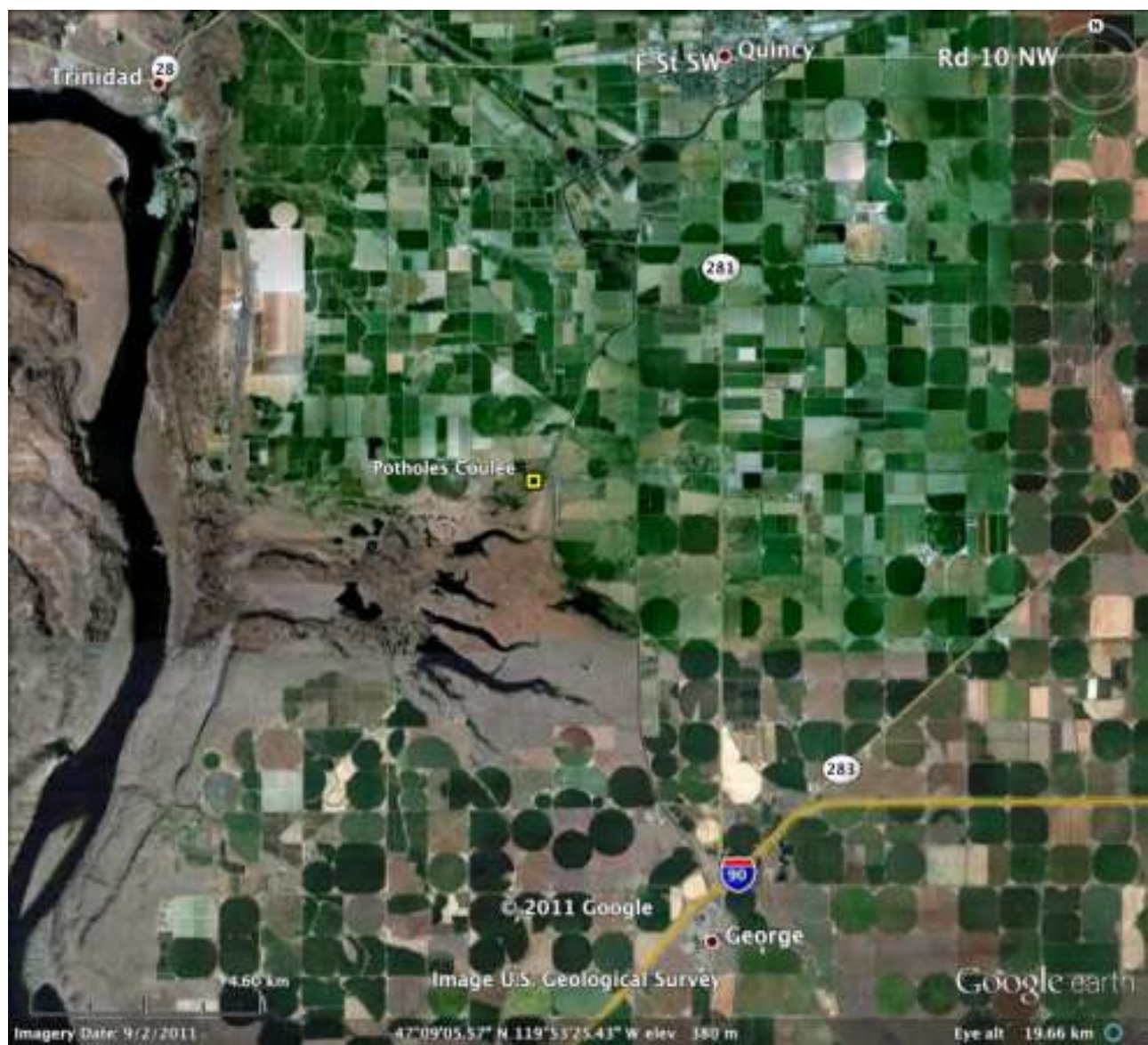

Figure 40 Location of Potholes Coulee field site, north of George, Washington. 


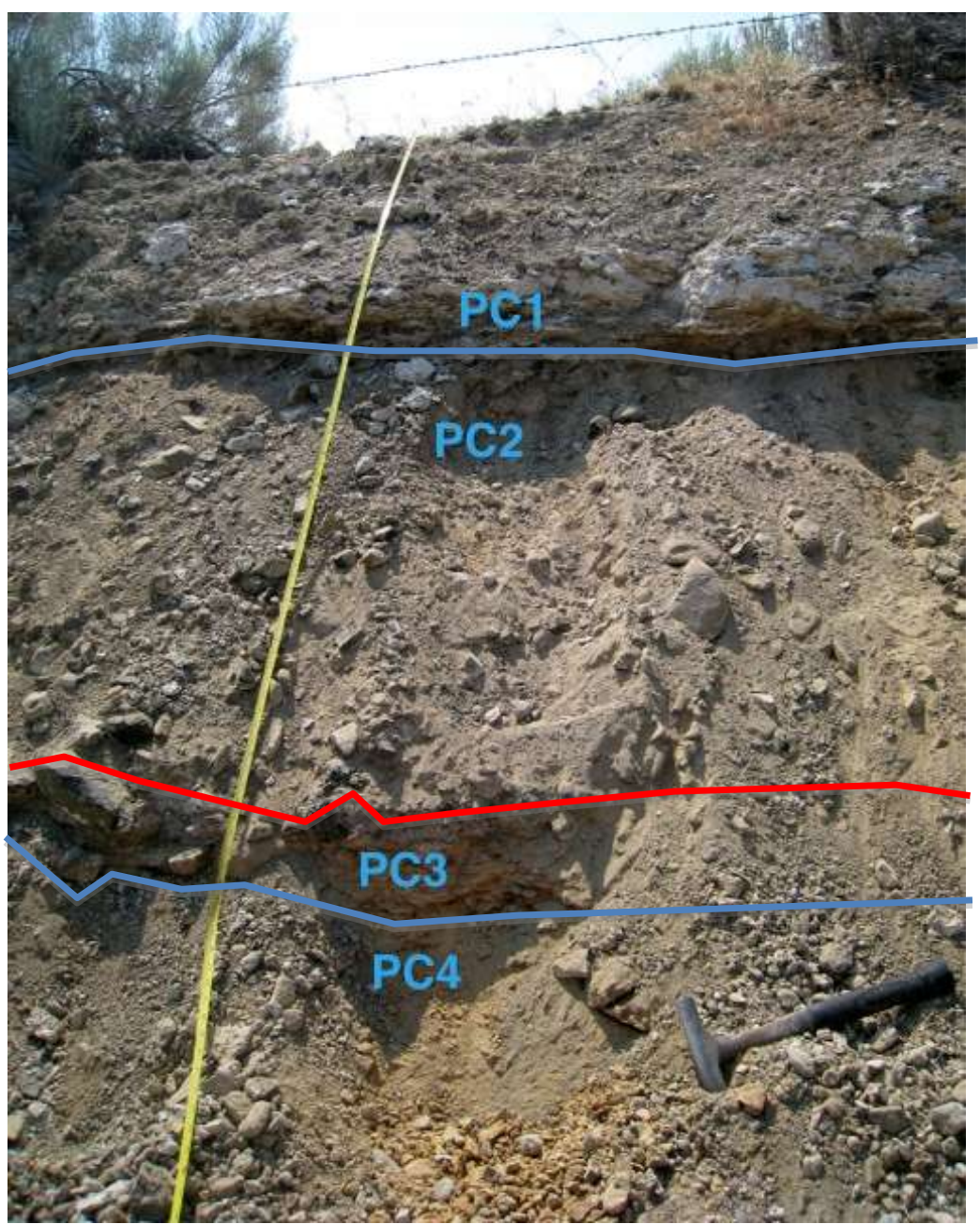

Figure 41 Potholes Coulee outcrop with sample locations labeled.

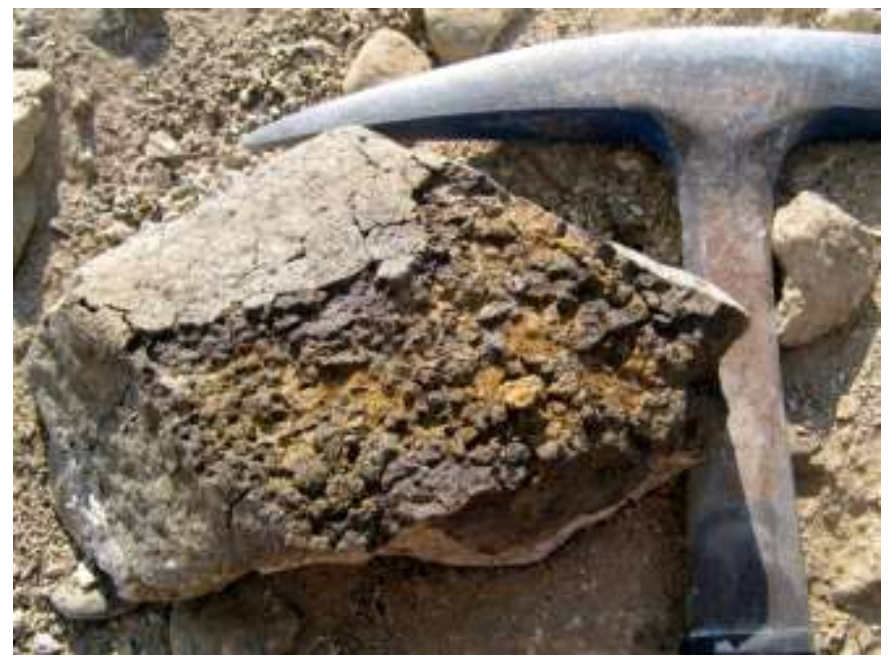

Figure 42 Highly weathered basalt clast (sample PC5) found in layer PC4 at Potholes Coulee outcrop. 


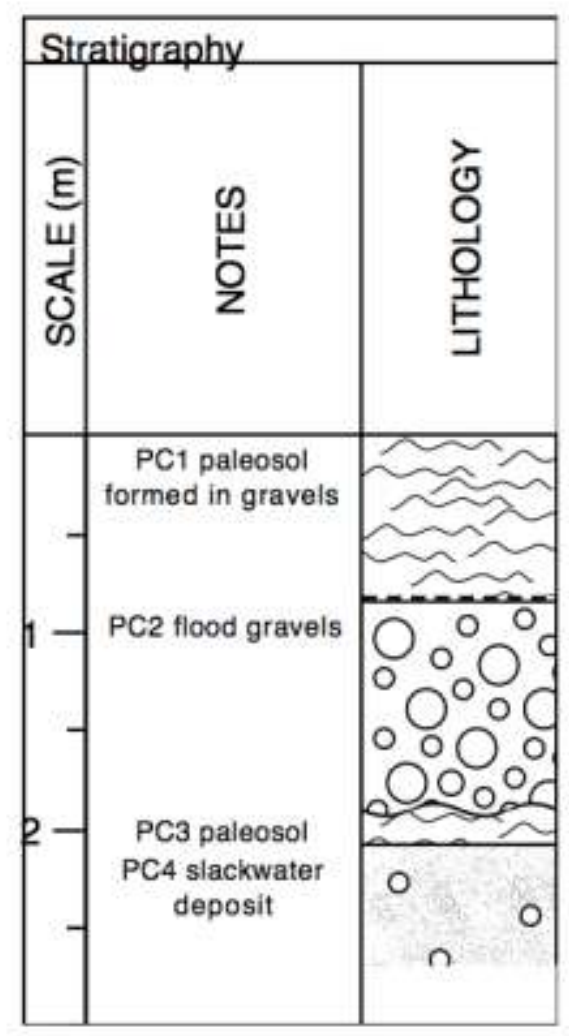

Figure 43 Stratigraphy of Potholes Coulee outcrop.

The Potholes Coulee field site is located along White Trail Road approximately $10 \mathrm{~km}$ north of George, Washington (Figure 40). The GPS coordinates for this site are N 47.160043 latitude and W -119.901514 longitude; the elevation is $388 \mathrm{~m}$. There are four stratigraphic layers: PC1 calcrete paleosol, PC2 flood gravels, PC3 calcrete paleosol, PC4 ancient flood slackwater deposit. The site has been analyzed by Bjornstad (2006) who describes evidence of a “...very old, large Ice Age flood spilling over Evergreen and Babcock ridges from west to east-opposite that of Scabland floods." His evidence is the east-dipping calcrete paleosols near the George landfill and Frenchmen Coulee.

The total section of the outcrop measures $356 \mathrm{~cm}$ thick (Figure 41). The top layer, $\mathrm{PC} 1$, from 0 to $89 \mathrm{~cm}$ is a thick calcrete paleosol, with $22.5 \% \pm 5.9 \mathrm{CaCO}_{3}$ and 
Stage III development (Table 13). The lower part of the PC1 gravel deposit, PC2, below the upper paleosol is a flood deposit composed of sand and basalt pebbles and measures $6.6 \% \pm 1.4 \mathrm{CaCO}_{3}$. The second calcrete paleosol, $\mathrm{PC} 3$, is much thinner, from 188 to $193 \mathrm{~cm}$, contains basalt pebbles and measures $11.0 \% \pm 0.5 \mathrm{CaCO}_{3}$, Stage II development. Layer PC4 is another potential ancient flood deposit with a finegrained matrix and gravel pieces, possibly a slackwater deposit. Sample PC5 was collected from the flood deposit in layer PC4; the coatings around highly weathered basalt clasts (Figure 42) measured $18.8 \% \pm 1.2 \mathrm{CaCO}_{3}$, Stage III development.

It takes hundreds of thousands of years for basalt to weather to this degree. Based on the degree of weathering and the advanced stages of $\mathrm{CaCO}_{3}$ development, the lower flood deposit, PC4, is probably Early Pleistocene in age and the upper flood deposit, PC2, is probably Early-Middle Pleistocene.

Table 13 Chittick results for Potholes Coulee site.

\begin{tabular}{|lcc|}
\multicolumn{1}{|c|}{ Sample ID } & $\begin{array}{c}\text { Average } \mathrm{CaCO}_{3} \\
\text { Percent }\end{array}$ & $\begin{array}{c}\text { Stage of } \\
\text { Development }\end{array}$ \\
\hline $\begin{array}{l}\text { PC1 calcrete paleosol } \\
\text { in flood gravels }\end{array}$ & $22.5 \pm 5.9$ & Stage III \\
\hline PC2 flood gravels & $6.6 \pm 1.4$ & Stage II \\
\hline $\begin{array}{l}\text { PC3 calcrete paleosol } \\
\text { in slackwater deposit }\end{array}$ & $11.0 \pm 0.5$ & Stage II \\
\hline $\begin{array}{l}\text { PC4 slackwater } \\
\text { deposit }\end{array}$ & $1.0 \pm 0.1$ & Stage I \\
\hline $\begin{array}{l}\text { PC5 calcrete coating } \\
\text { on boulder in PC4 }\end{array}$ & $18.8 \pm 1.2$ & Stage III \\
\hline
\end{tabular}




\subsubsection{Frenchmen Coulee (George, Washington)}

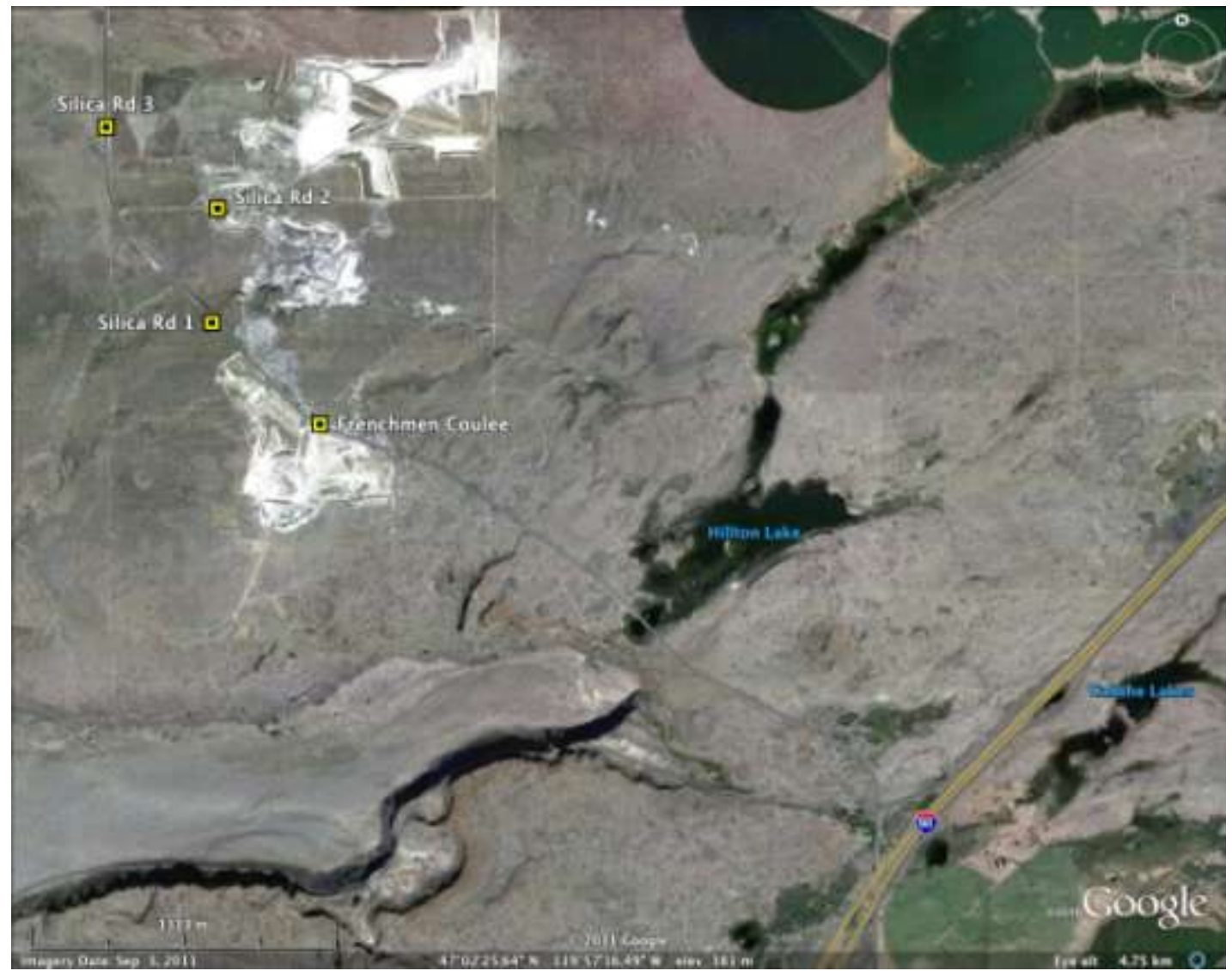

Figure 44 Location of the Frenchmen Coulee field site near George, Washington.

Frenchmen Coulee is located 9.6 km southwest of George, Washington along Silica Road (exit 143 from I-90) (Figure 44). The GPS coordinates for this site are N 47.042778 latitude and $\mathrm{W}-119.970768$ longitude; the elevation is $413.0 \mathrm{~m}$.

Frenchmen Coulee has "evidence for a very old, large Ice Age Flood" that originated from the west (as opposed to Glacial Lake Missoula to the east) (Bjornstad, 2006). These stratigraphic layers were described here: an upper A horizon of the soil; FC1, a calcrete paleosol; and FC2, highly weathered basalt (Figure 45). 


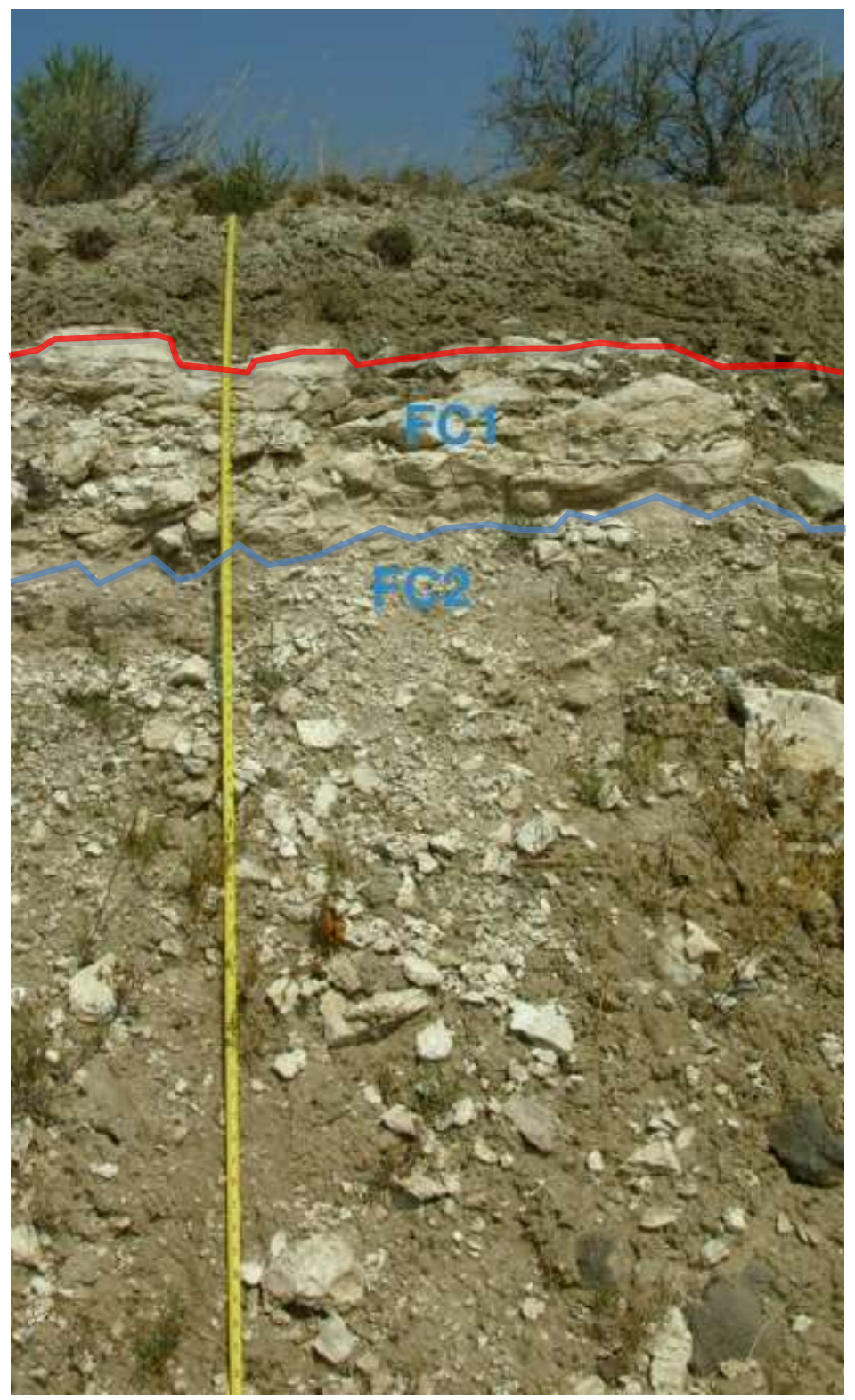

Figure 45 Frenchmen Coulee outcrop with sample locations labeled.

The "A" soil horizon comprises the upper $46 \mathrm{~cm}$ of the outcrop and seems to have formed in recent loess. An unconformity separates the soil horizon from the calcrete paleosol layer FC1. The calcrete is formed in mostly silt with scattered basalt gravels. The paleosol is $104 \mathrm{~cm}$ thick and measures $27.9 \% \pm 5.2 \mathrm{CaCO}_{3}$, Stage III development (Table 14). The paleosol overlies highly weathered basalt bedrock, FC2 (Figure 47). I interpret the paleosol to be at least Middle Pleistocene in age. 


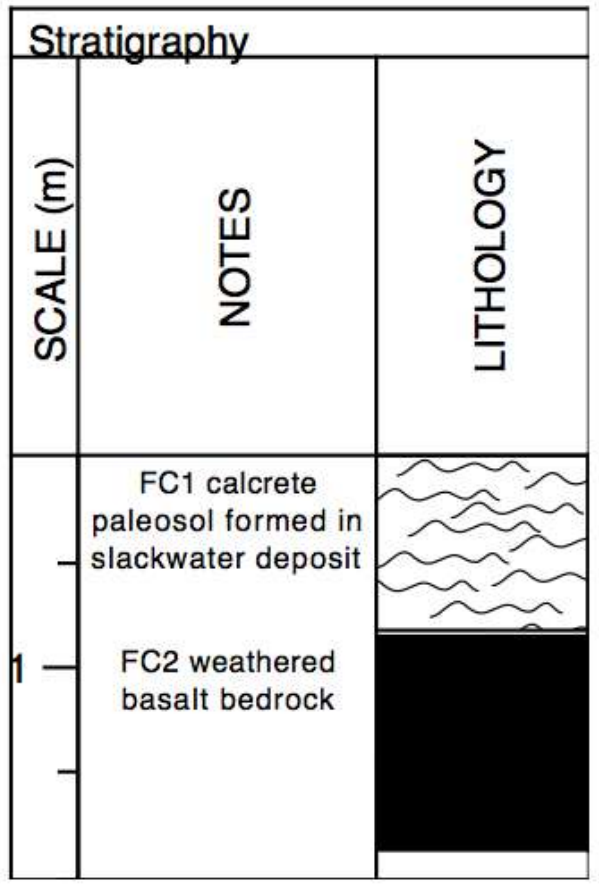

Figure 46 Stratigraphy of Frenchmen Coulee outcrop.

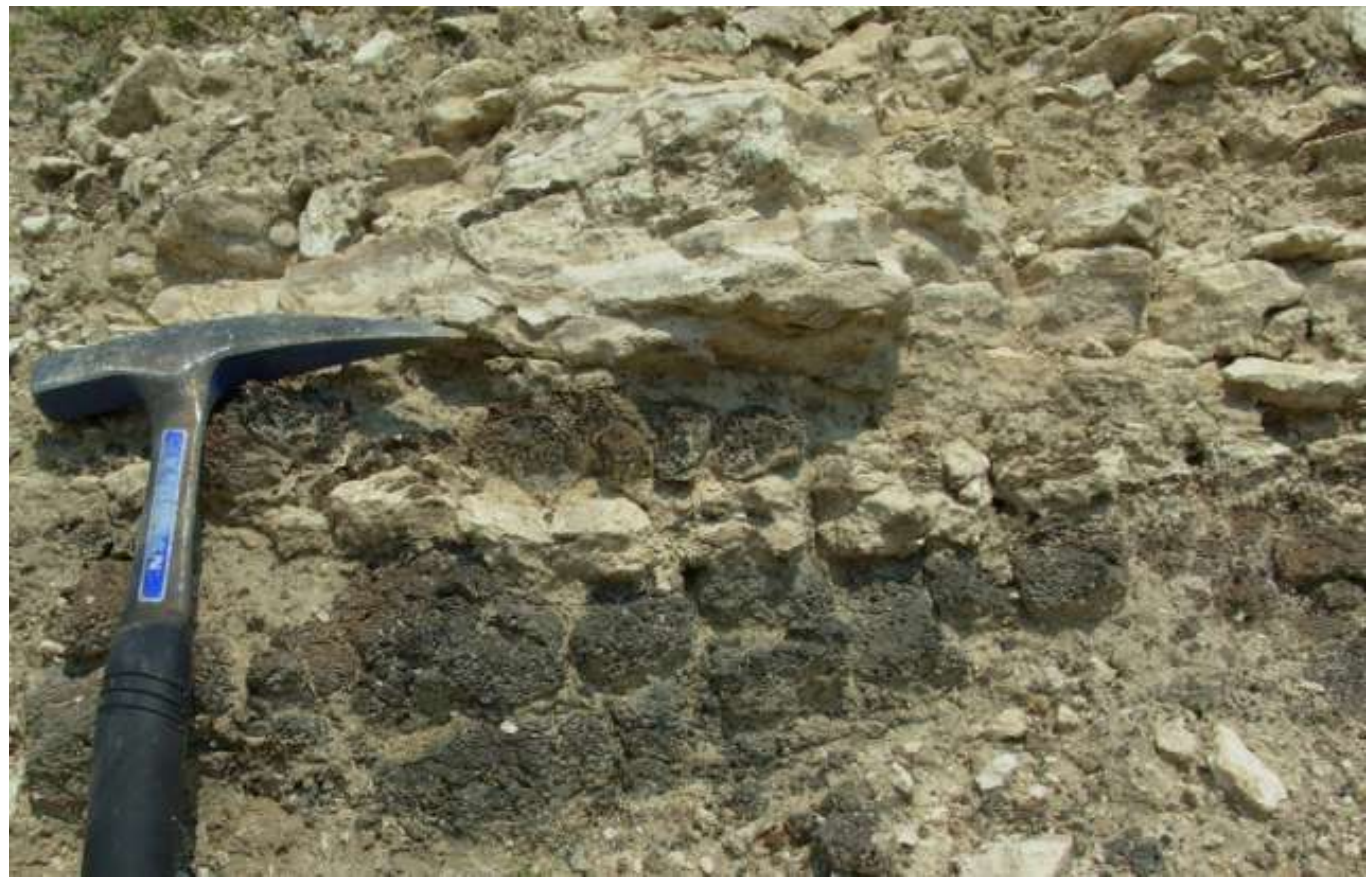

Figure 47 Close-up of the contact between weathered basalt bedrock and calcrete paleosol at Frenchmen Coulee. 
Table 14 Chittick results for Frenchmen Coulee site.

\begin{tabular}{|l|cc|}
\hline \multicolumn{1}{|c|}{ Sample ID } & $\begin{array}{c}\text { Average } \mathrm{CaCO}_{3} \\
\text { Percent }\end{array}$ & $\begin{array}{c}\text { Stage of } \\
\text { Development }\end{array}$ \\
\hline $\begin{array}{l}\text { FC1 calcrete paleosol } \\
\text { in slackwater deposit }\end{array}$ & $27.9 \pm 5.2$ & Stage III \\
\hline
\end{tabular}

\subsubsection{Silica Road (George, Washington)}

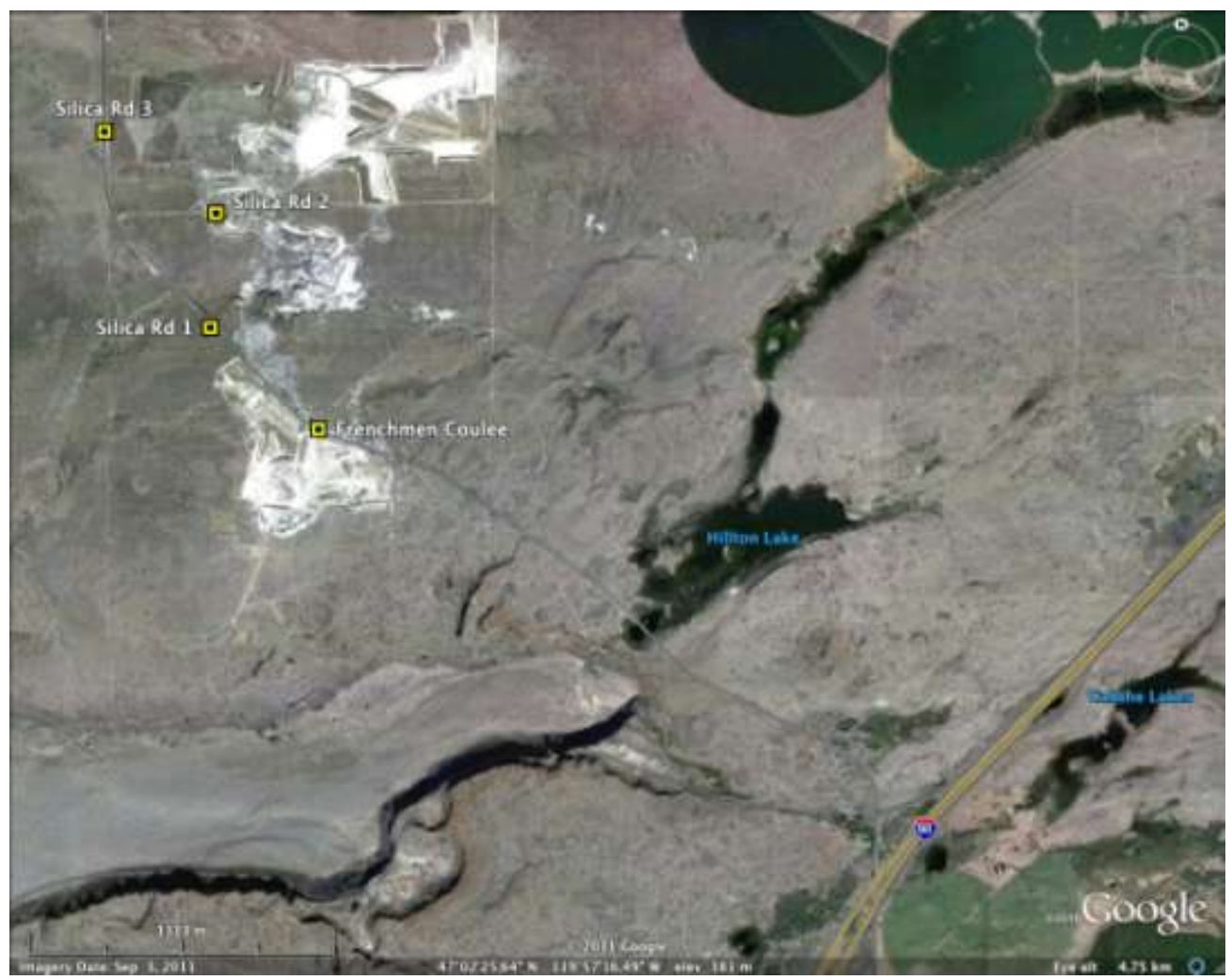

Figure 48 Location of the Silica Road field sites near George, Washington.

The Silica Road outcrops are located approximately $3.6 \mathrm{~km}$ northwest of I-90, just north of the Frenchmen Coulee outcrop (Figure 48). I discovered the outcrops doing field work in the summer of 2010. The GPS coordinates for Silica Road 1 are N 47.046525 latitude and W -119.976711 longitude; the elevation is $402 \mathrm{~m}$. The GPS coordinates for Silica Road 2 are N 47.050727 latitude and W -119.9976364 
longitude; the elevation is $415 \mathrm{~m}$. The GPS coordinates for Silica Road 3 are N

47.053686 latitude and W -119.982361 longitude; the elevation is $427 \mathrm{~m}$. No samples were taken because the sites are on private property. Each site contained a prominent calcrete paleosol in slackwater deposits with a gravelly flood deposit below, composed of basalt gravels (Figure 49). Further north along Silica Road there is a more discontinuous calcrete layer with weathered basalt bedrock below (Figure 50). The outcrop appears to have Stage II-III soil development and I suggest that it is Middle Pleistocene in age; however, the outcrop needs to be sampled and tested.

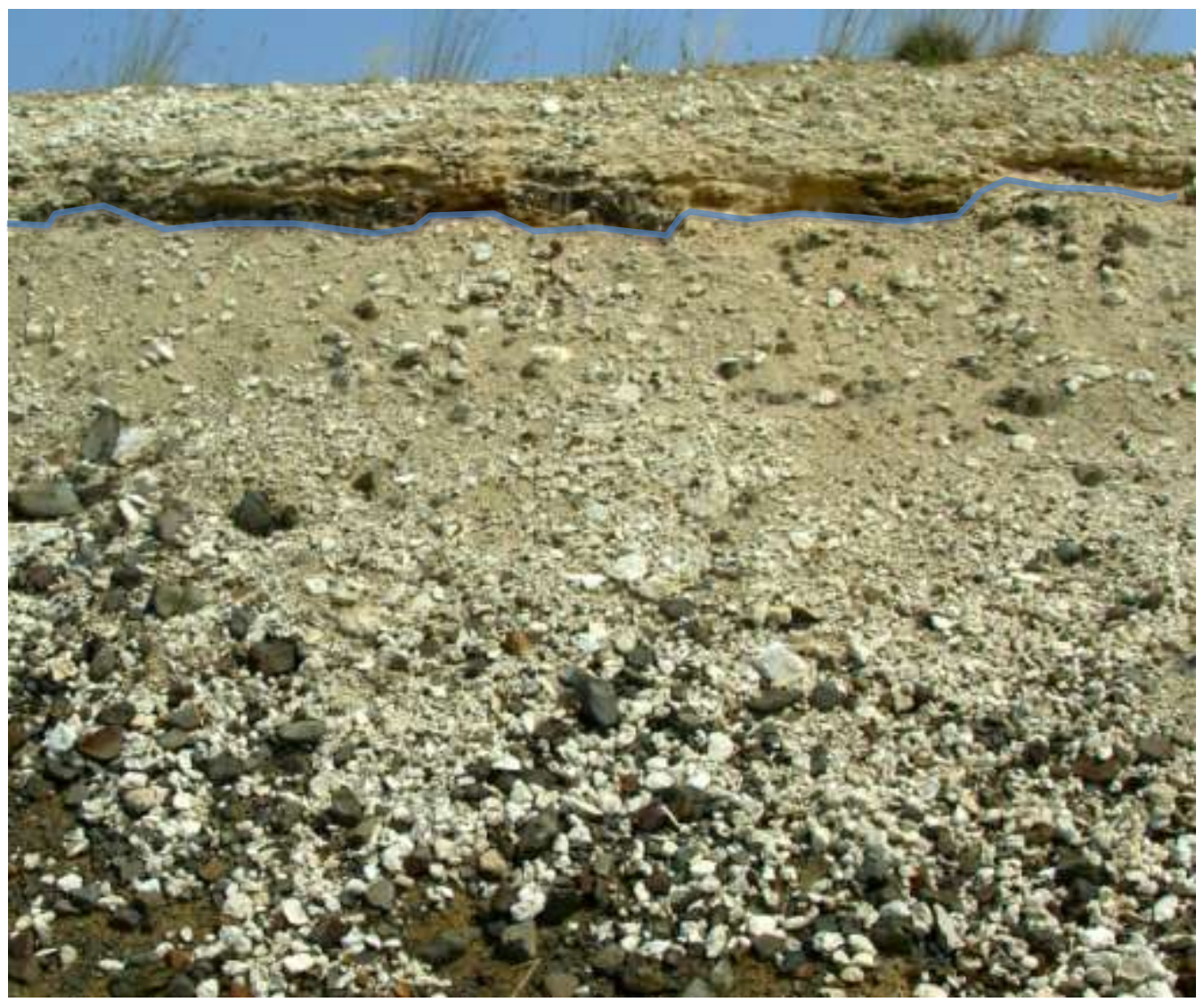

Figure 49 Silica Road 1 outcrop. 


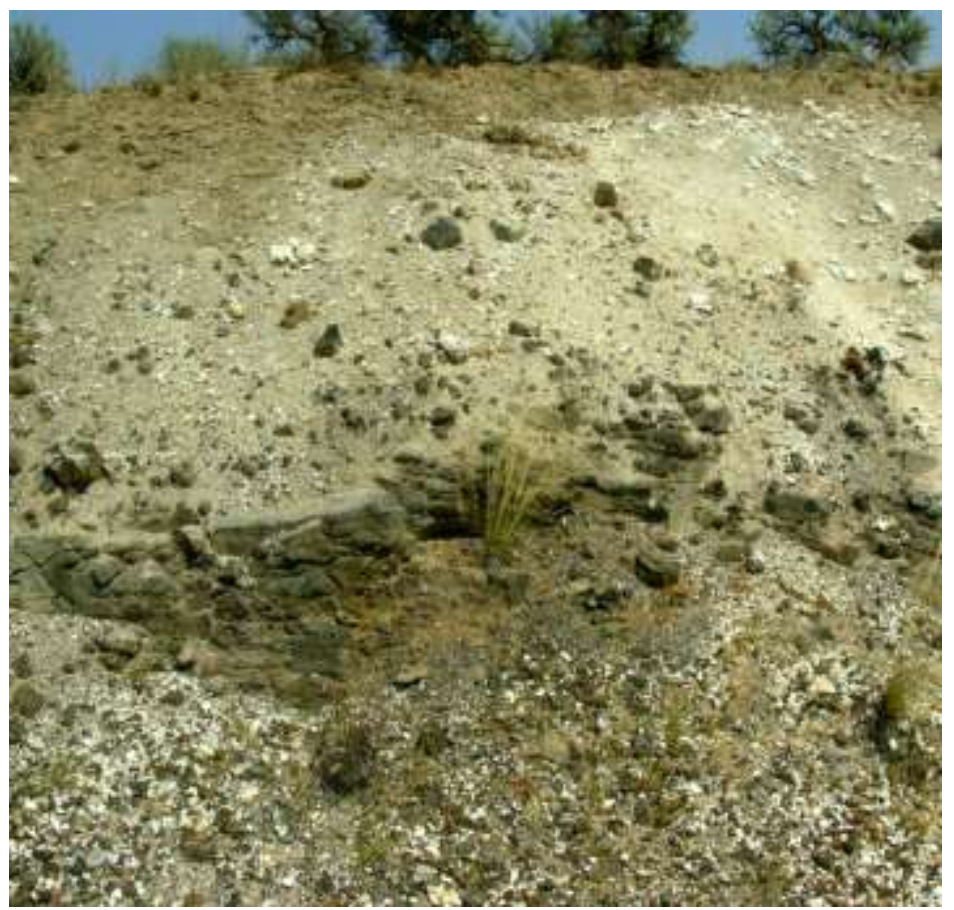

Figure 50 Silica Road 2 outcrop.

\subsubsection{Reese Coulee (Touchet, Washington)}

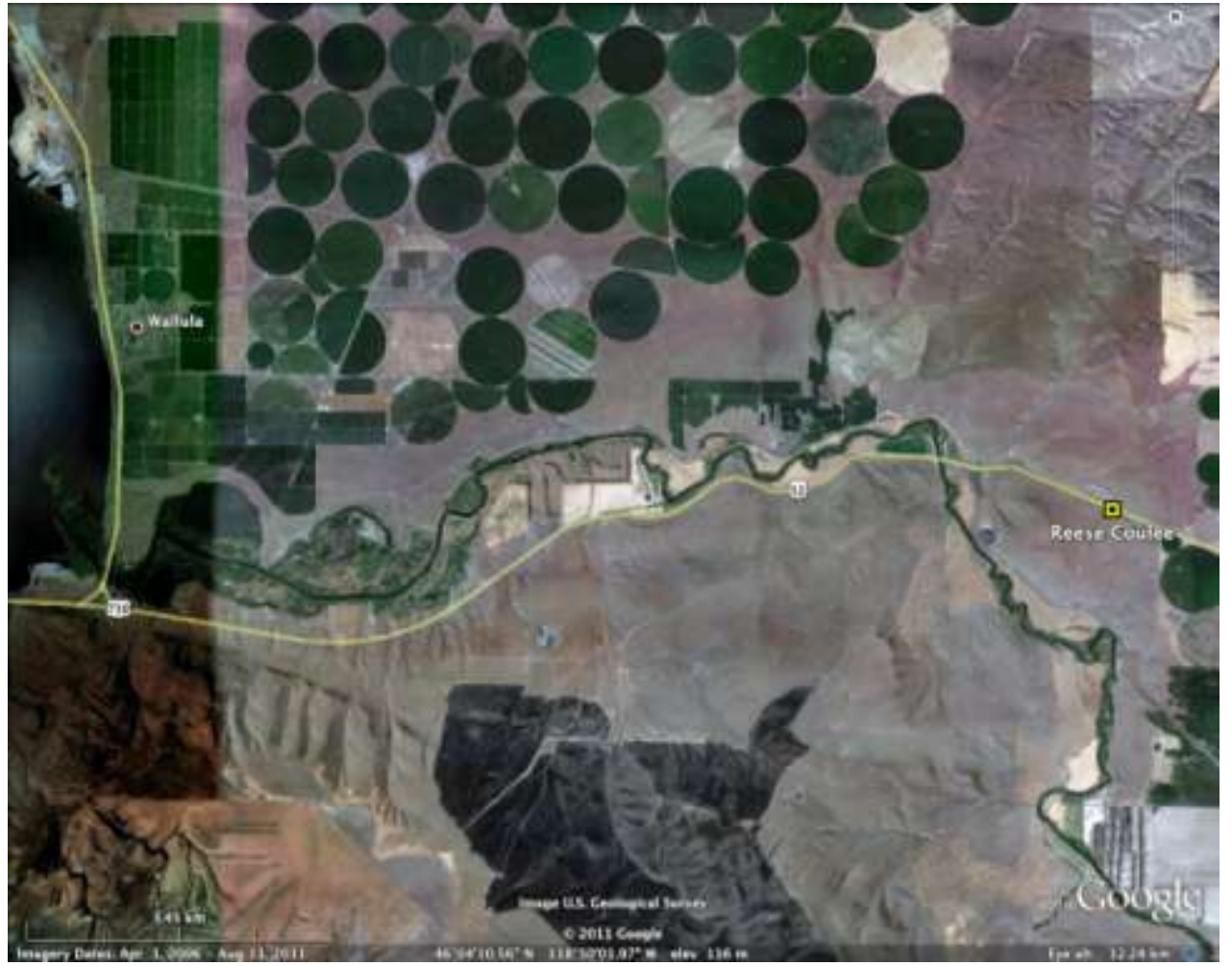

Figure 51 Location of the Reese Coulee field site, west of Wallula, Washington. 
Reese Coulee is located along U.S. 12, $11.6 \mathrm{~km}$ west of Wallula Junction (Figure 51). The GPS coordinates for this site are N 46.067093 latitude and W 118.759532 longitude; the elevation is $193 \mathrm{~m}$. Many stratigraphic layers of calcrete paleosols are found here. I sampled four places at the bottom of the stratigraphic section: RC1, RC2, RC3 and RC4.

The outcrop was previously interpreted by Bjornstad et al. (2001), Jaffee and Spencer (2000), and Bjornstad (2006). Bjornstad (2006) found ice-rafted, highly weathered granite boulders at the base of the section. "The exact age of the flood(s) that carved the coulee and deposited the erratic is uncertain, but a minimum age of 770,000 (or 790,000) years ago is based on the reversed magnetic polarity, measured in the fine-grained sediments that enclose the erratic" (Bjornstad, 2006).

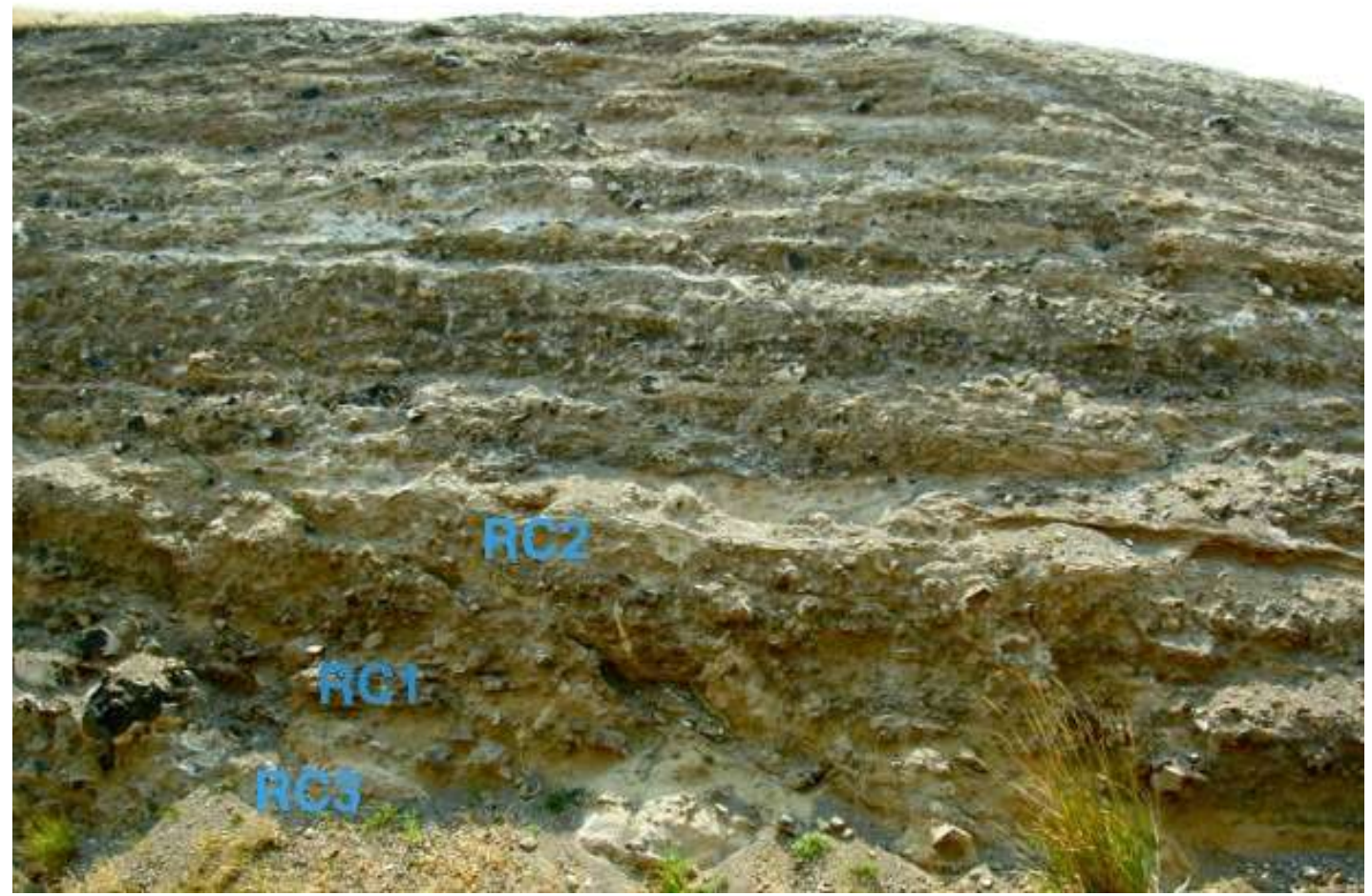

Figure 52 Reese Coulee outcrop with sample locations labeled. Photo by Kat Barnard 


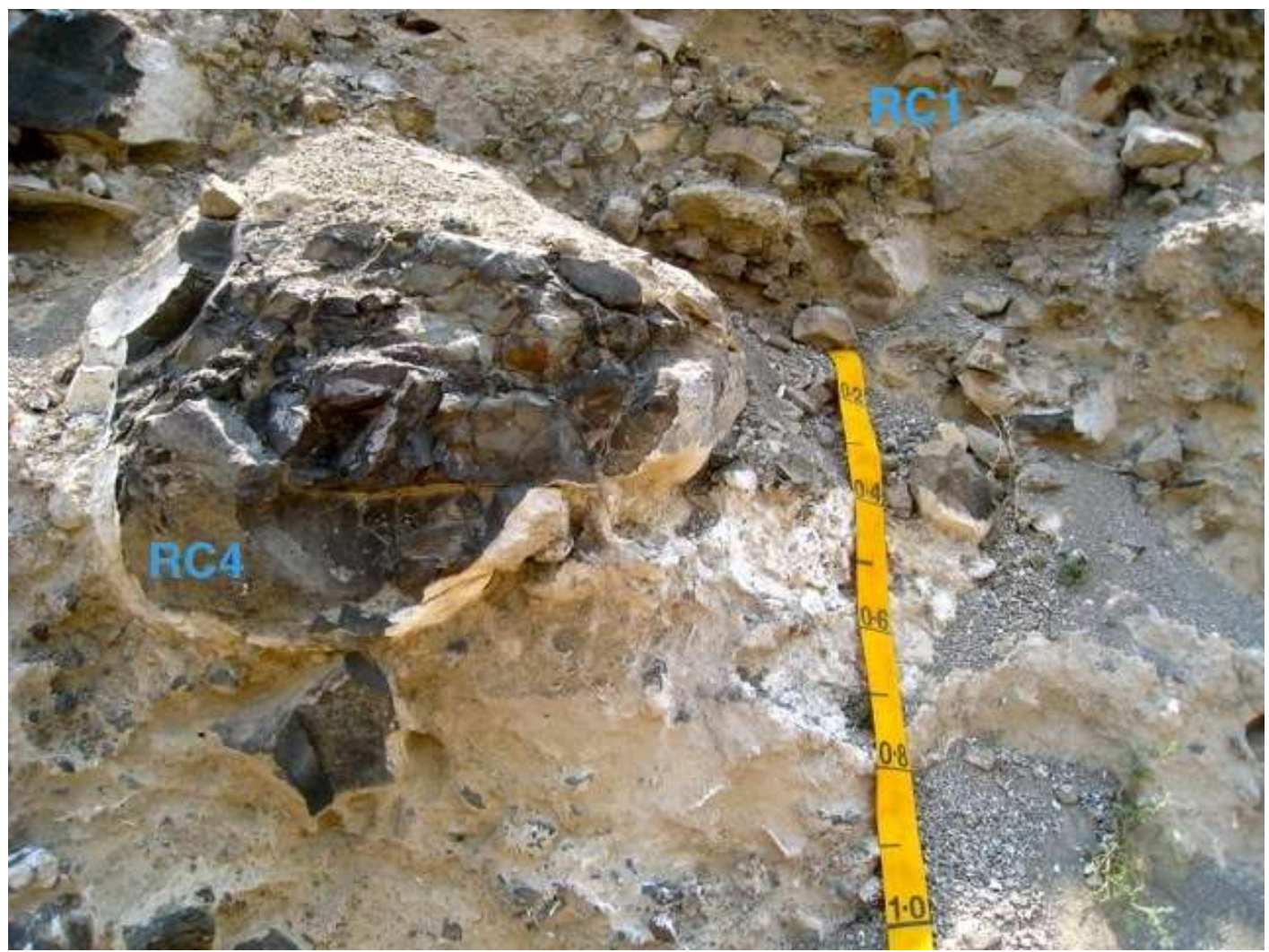

Figure 53 Basalt boulder covered in calcrete, sample locations labeled.

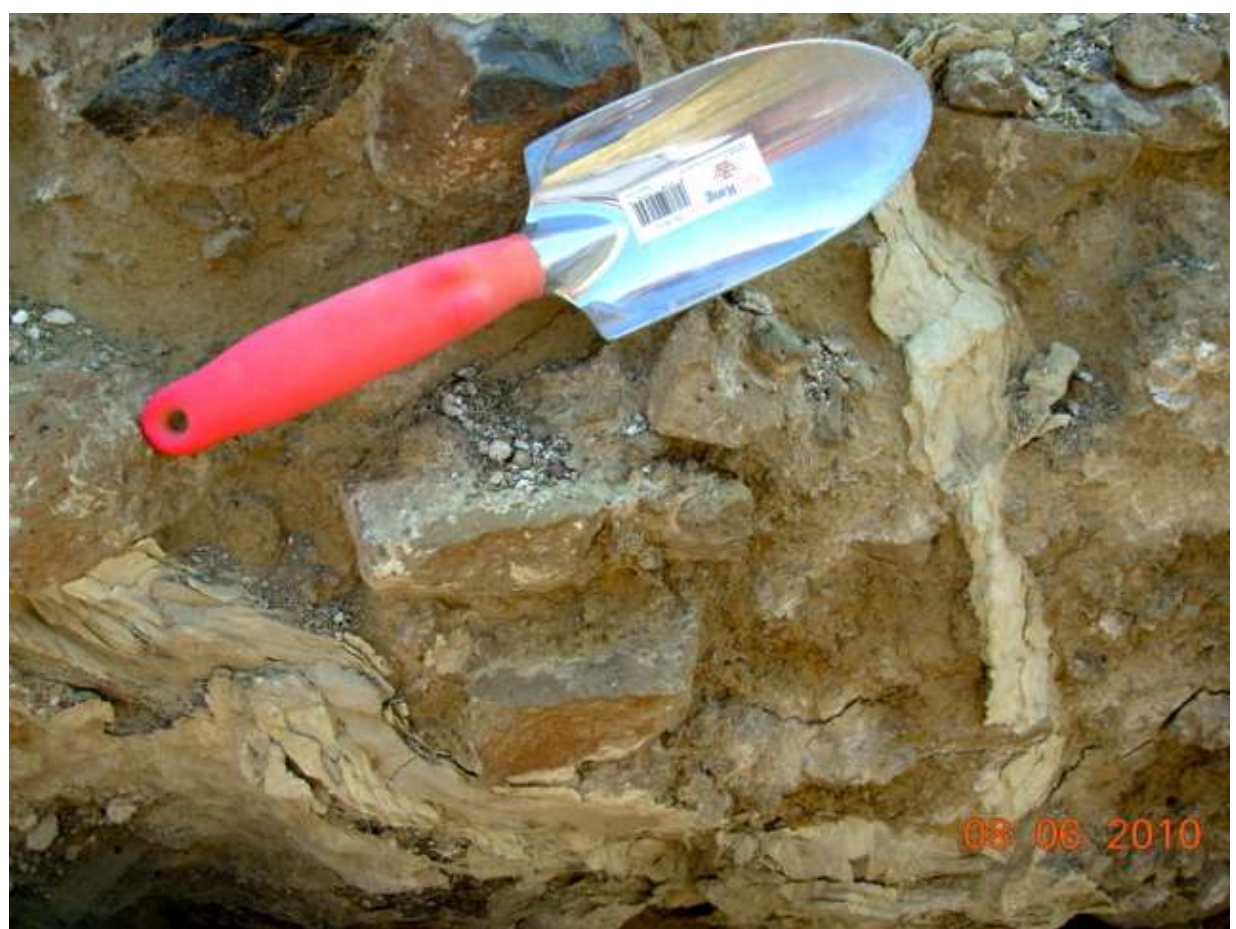

Figure 54 Clastic silt dike at Reese Coulee outcrop. Photo Kat Barnard 
At least eight separate calcrete paleosols in flood gravels are counted at the outcrop, each of which overlies a sandy to gravelly flood deposit (Figure 52). The calcrete covering the weathered basalt boulder (Figure 53), sample RC4, measured $17.9 \% \pm 0.7 \mathrm{CaCO}_{3}$, Stage III development. Sample RC1, $1.2 \% \pm 0.4 \mathrm{CaCO}_{3}$ was collected in the flood deposit adjacent to the basalt boulder. RC3 was collected below the flood deposit and contained $0.5 \% \pm 0.2 \mathrm{CaCO}_{3}$. Sample RC2 was collected in the calcrete paleosol overlying the flood deposit and contained $14.7 \% \pm 0.3$ $\mathrm{CaCO}_{3}$, Stage II+ calcrete development. Many clastic injection dikes are present at the outcrop (Figure 54). Based on reversed magnetic polarity, there is at least one Early Pleistocene flood deposit and many more Early-Middle Pleistocene deposits separated by calcrete paleosols.

Table 15 Chittick results for Reese Coulee site.

\begin{tabular}{|c|c|c|}
\hline Sample ID & $\begin{array}{c}\text { Average } \mathrm{CaCO}_{3} \\
\text { Percent }\end{array}$ & $\begin{array}{c}\text { Stage of } \\
\text { Development }\end{array}$ \\
\hline RC1 flood gravels & $1.2 \pm 0.4$ & Stage I \\
\hline $\begin{array}{l}\text { RC2 calcrete in flood } \\
\text { gravels }\end{array}$ & $14.7 \pm 0.3$ & Stage II+ \\
\hline RC3 flood gravels & $0.5 \pm 0.2$ & Stage I \\
\hline $\begin{array}{l}\text { RC4 calcrete rind on } \\
\text { boulder in RC3 }\end{array}$ & $17.9 \pm 0.7$ & Stage III \\
\hline
\end{tabular}




\subsubsection{Cummins Bridge (Touchet, Washington)}

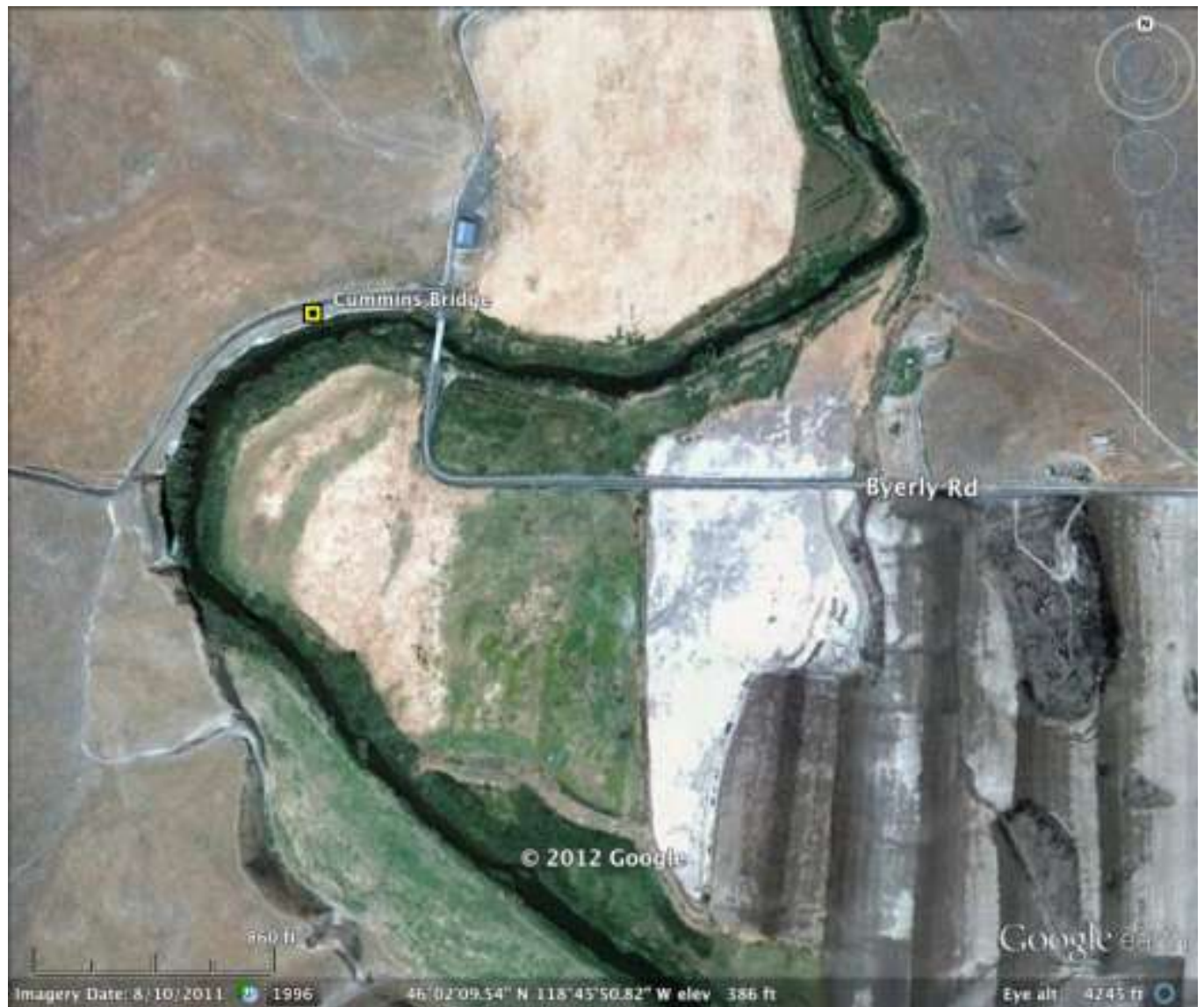

Figure 55 Location of the Cummins Bridge field site near Touchet, Washington.

The Cummins Bridge outcrop is located off of Byrnes Road $3.5 \mathrm{~km}$ southeast of U.S. 12 (Figure 55). The GPS coordinates for this site are N 46.0379625 latitude and W -118.7683583 longitude; the elevation is $117 \mathrm{~m}$. Two stratigraphic layers are described, CB1, Missoula Flood rhythmites, and CB2 Ancient Cataclysmic gravels. Burns and Medley estimate approximately 30 meters of Missoula Flood rhythmites (layer CB1) ranging in thickness, from $20 \mathrm{~cm}$ to several meters thick. No samples were collected because of the inaccessibility of the outcrop. 


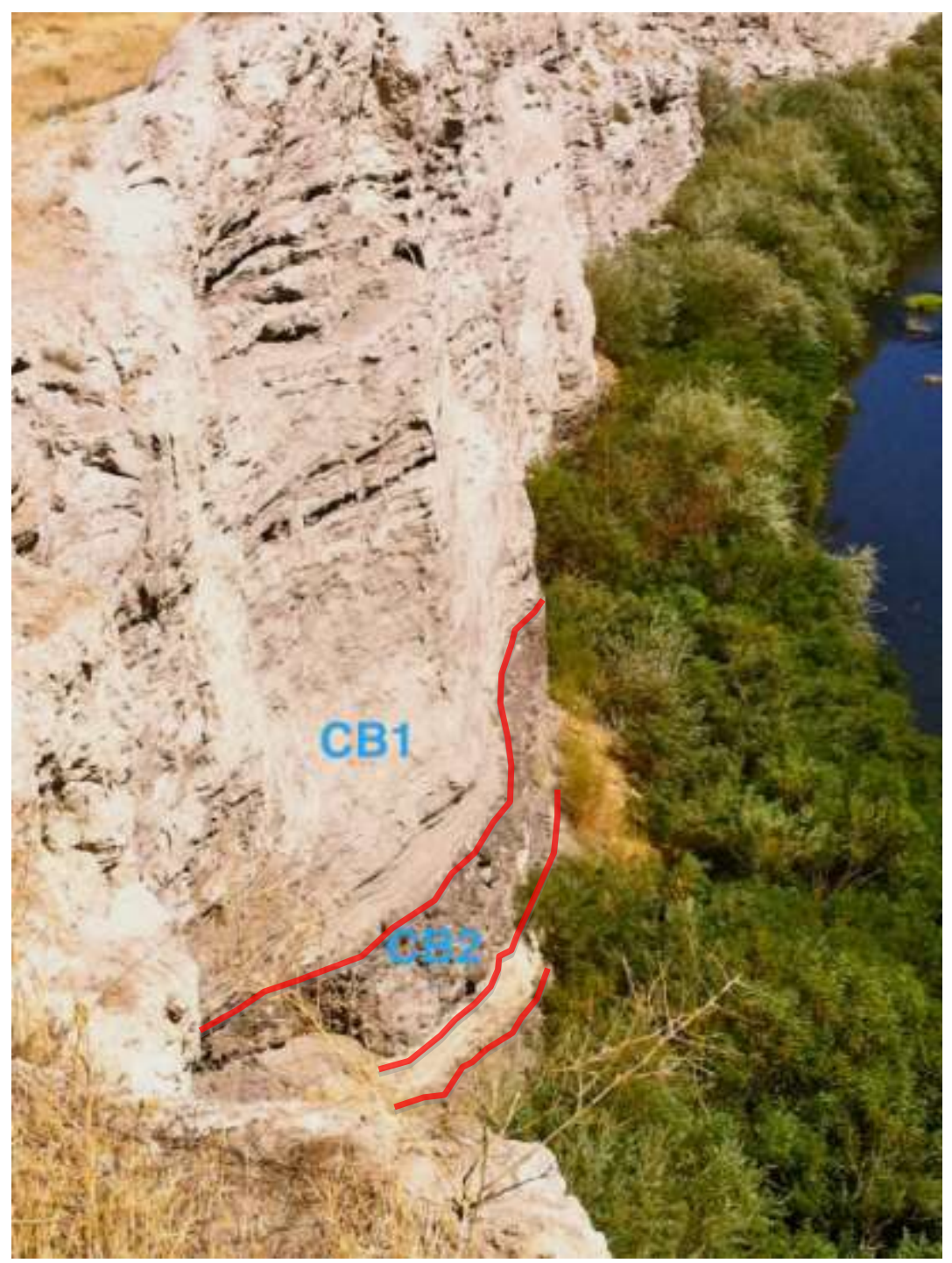

Figure 56 Cummins Bridge outcrop.

Approximately $1.5 \mathrm{~m}$ of old gravels (layer CB2) underlie the rhythmites, separated by an unconformity. Another unconformity below the gravels separates an old rhythmite sequence that is approximately $0.6 \mathrm{~m}$ thick, which unconformably overlies basalt bedrock or possibly more old gravels. This site is unique because there is evidence for strong flood waters (gravels) and low energy slackwater deposits (rhythmites) (Figure 56). Bjornstad (2006) measured the older slackwater rhythmites beneath the gravels to have normal magnetic polarity placing the 
deposit younger than 790,000 years ago. The deposits are probably Middle Pleistocene, between 130,000 and 790,000 thousand years ago.

\subsubsection{Connell (Connell, Washington)}

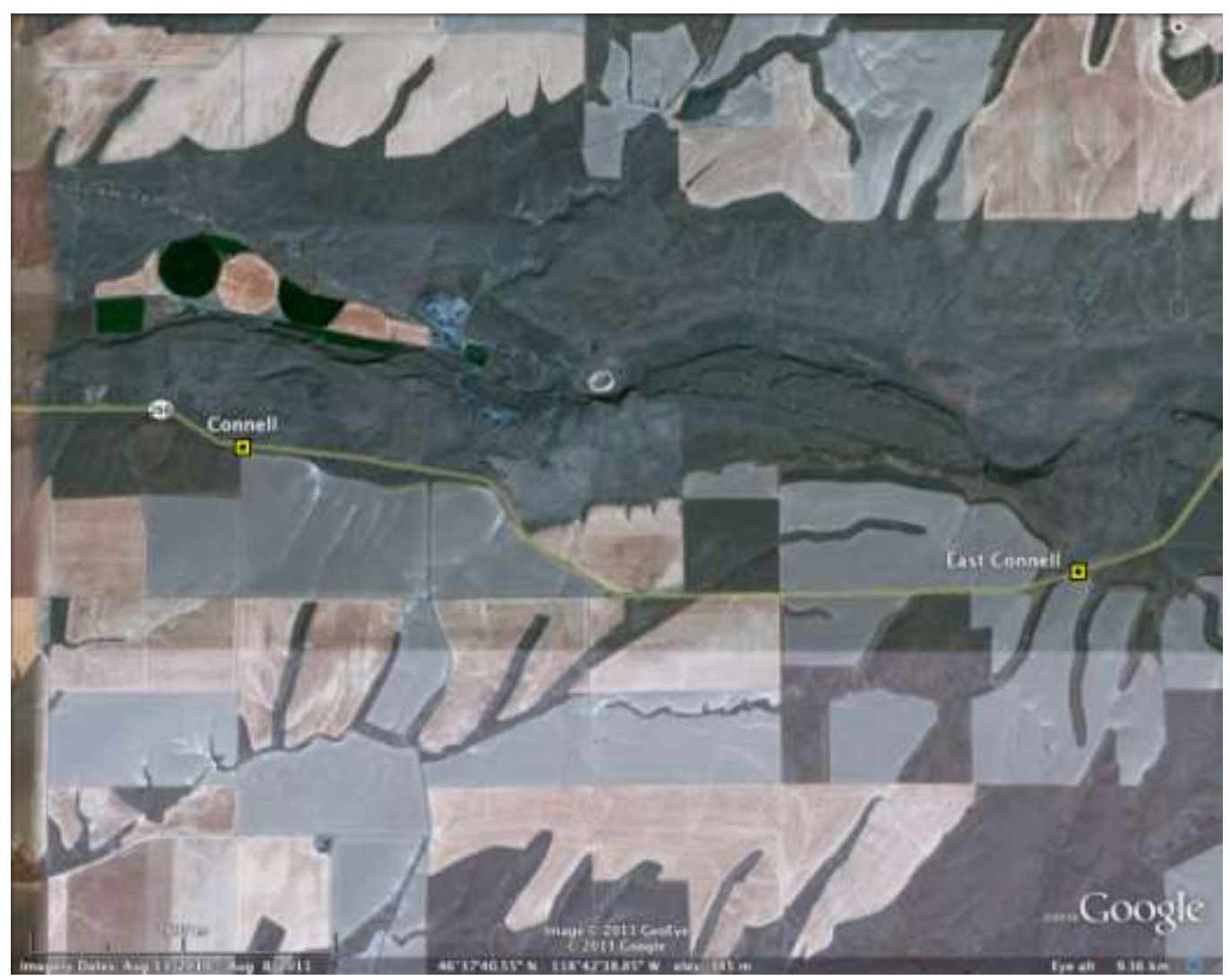

Figure 57 Connell field site location.

The Connell field site is located along Highway 260 approximately $8.2 \mathrm{~km}$ west of U.S. 395 (Figure 57). The GPS coordinates for this site are N 46.631671 latitude and W - -118.752708 longitude; the elevation is $349 \mathrm{~m}$. Two stratigraphic layers were sampled, CON2 and CON3. 


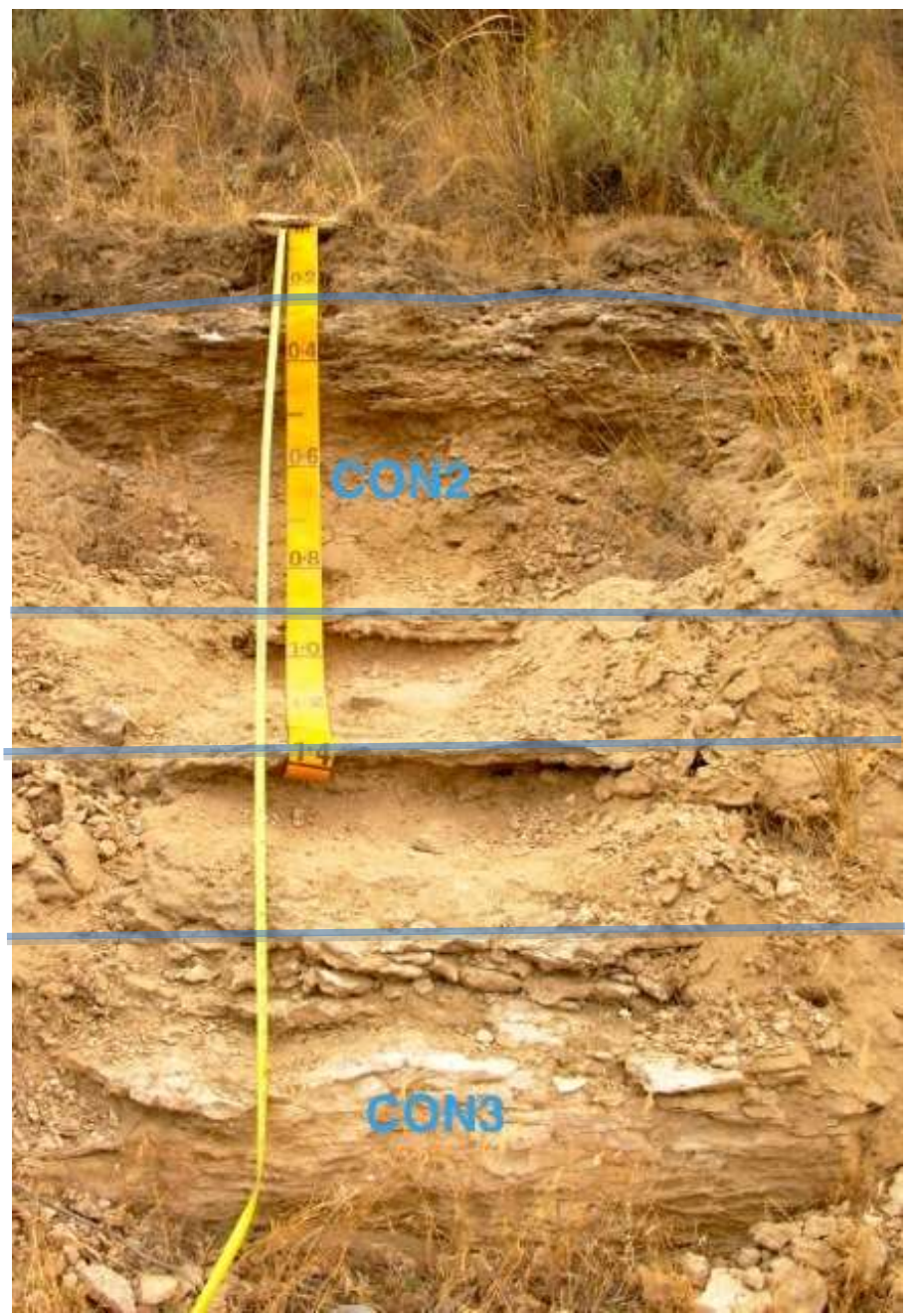

Figure 58 Connell outcrop with sample locations labeled.

The section appears to be entirely composed of calcrete with more and less resistant layers. The more resistant layers are marked in (Figure 58). Baker et al. (1991) hypothesized that there is evidence for one Middle Pleistocene flood at this location based on Mount St. Helens set C tephra that "fills a flood-scoured depression cut into underlying paleosols and loess; thus, the flood that cut the unconformity occurred just prior to 36 ka." Sample CON2 was collected just below the uppermost resistant ledge, and CON3 is from the thickest and most strongly lithified calcrete layer at the base. Both layers consist of fine sand to silt containing 
quartz and basalt sand. Based on the high amounts of $\mathrm{CaCO}_{3}$ in the paleosol samples, $16.6 \% \pm 1.8$ and $25.0 \% \pm 5.3$ Stages II + and III calcrete development, any flood deposits that were subsequently scoured are at least $36 \mathrm{ka}$ (Table 16).

Table 16 Chittick results for Connell site.

\begin{tabular}{|lcc|}
\hline \multicolumn{1}{|c}{ Sample ID } & $\begin{array}{c}\text { Average } \mathrm{CaCO}_{3} \\
\text { Percent }\end{array}$ & $\begin{array}{c}\text { Stage of } \\
\text { Development }\end{array}$ \\
\hline $\begin{array}{l}\text { CON2 calcrete in } \\
\text { slackwater deposit }\end{array}$ & $16.6 \pm 1.8$ & Stage II+ \\
\hline $\begin{array}{l}\text { CON3 calcrete in } \\
\text { slackwater deposit }\end{array}$ & $25.0 \pm 5.3$ & Stage III \\
\hline
\end{tabular}

\subsubsection{East Connell (Kahlotus, Washington)}

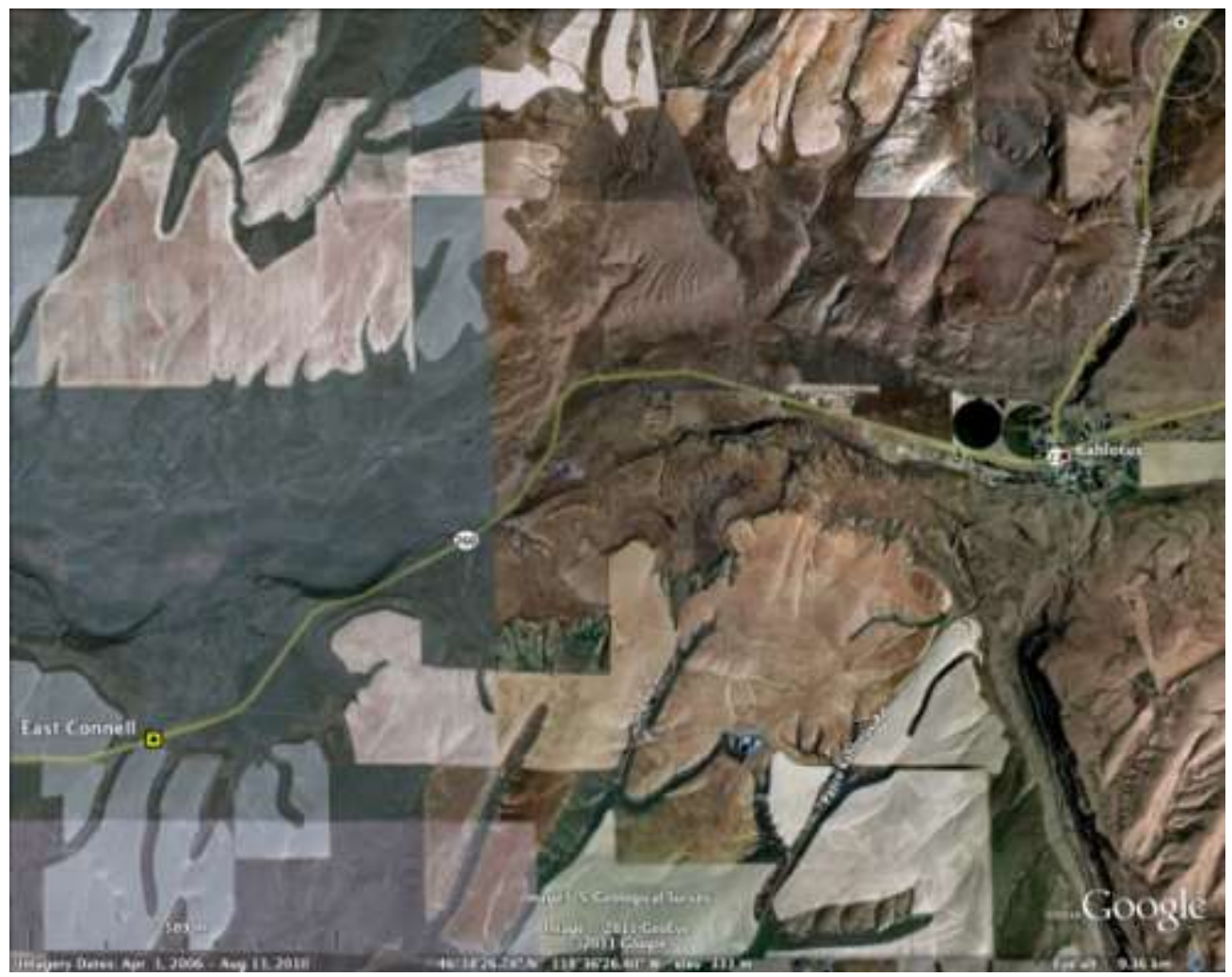

Figure 59 Location of the East Connell field site, west of Kahlotus, Washington. 


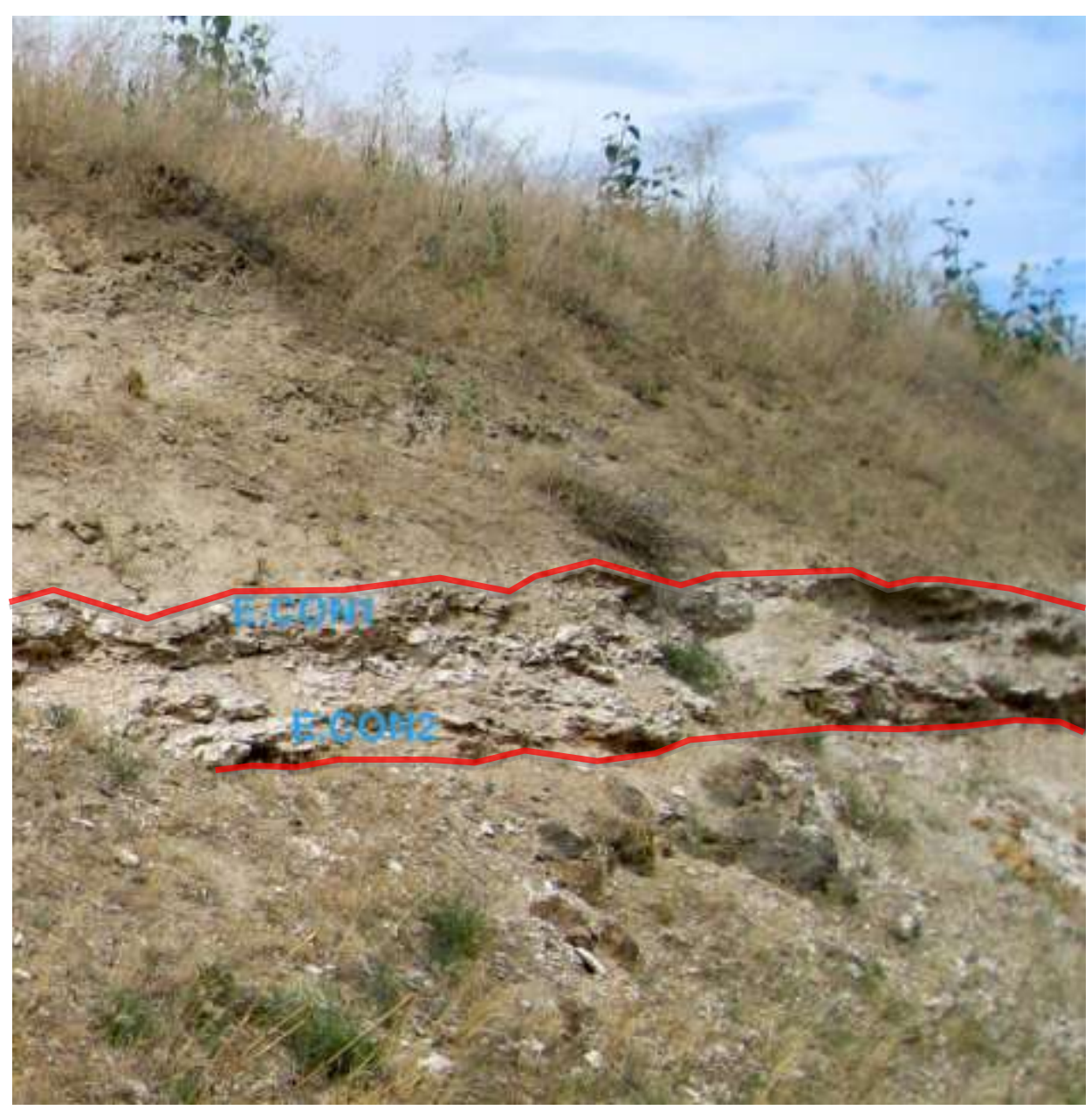

Figure 60 East Connell field site with sample locations labeled.

The East Connell site is located approximately $8 \mathrm{~km}$ east of the Connell site along Highway 260 and 9.2 km west of Kahlotus, Washington (Figure 59). The GPS coordinates for this site are N 46.62187 latitude and W -118.659126 longitude; the elevation is $384 \mathrm{~m}$. Two samples were taken from the upper and lower part of the calcrete formed in basalt gravels at the site (Figure 60). 


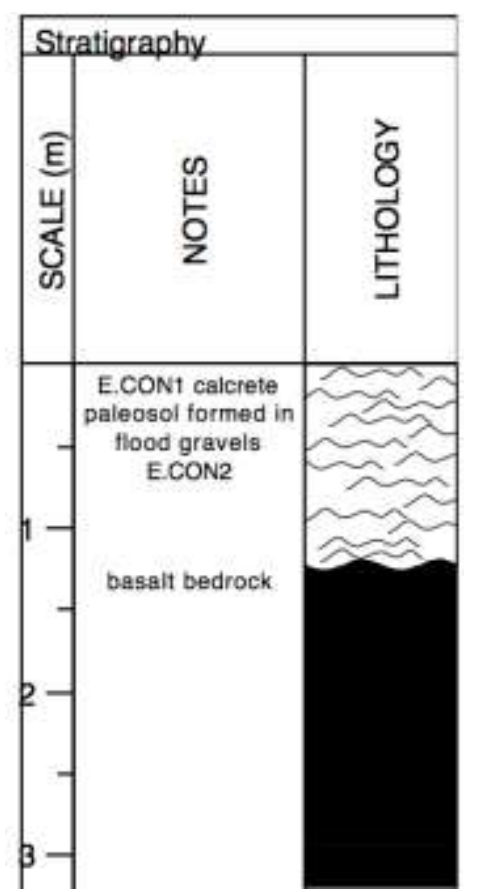

Figure 61 Stratigraphy of East Connell outcrop.

This is a new site that most likely correlates to the Connell site based on proximity. The calcrete paleosol with basalt gravels is $230 \mathrm{~cm}$ thick and is bounded by unconformities. Weathered basalt bedrock lies below the lower unconformity. The two samples were taken in the upper resistant calcrete, E.CON1, and the lower resistant calcrete layer, E.CON2. The percent of $\mathrm{CaCO}_{3}$ in the samples, $18.1 \% \pm 0.6$ and $25.2 \% \pm 5.8$ and Stage III development, correlates closely with the Connell samples (Table 17). Any scoured away flood deposits are in the same age range as those at the Connell site, at least $36 \mathrm{ka}$.

Table 17 Chittick results for East Connell site.

\begin{tabular}{|lcc|}
\hline \multicolumn{1}{|c|}{ Sample ID } & $\begin{array}{c}\text { Average } \mathrm{CaCO}_{3} \\
\text { Percent }\end{array}$ & $\begin{array}{c}\text { Stage of } \\
\text { Development } \\
\text { Stage III }\end{array}$ \\
\hline $\begin{array}{l}\text { E.CON1 calcrete in } \\
\text { flood gravels }\end{array}$ & $18.1 \pm 0.6$ & Stage III \\
\hline $\begin{array}{l}\text { E.CON2 calcrete in } \\
\text { flood gravels }\end{array}$ & $25.2 \pm 5.8$ & \\
\hline
\end{tabular}




\subsubsection{Marengo (Ritzville, Washington)}

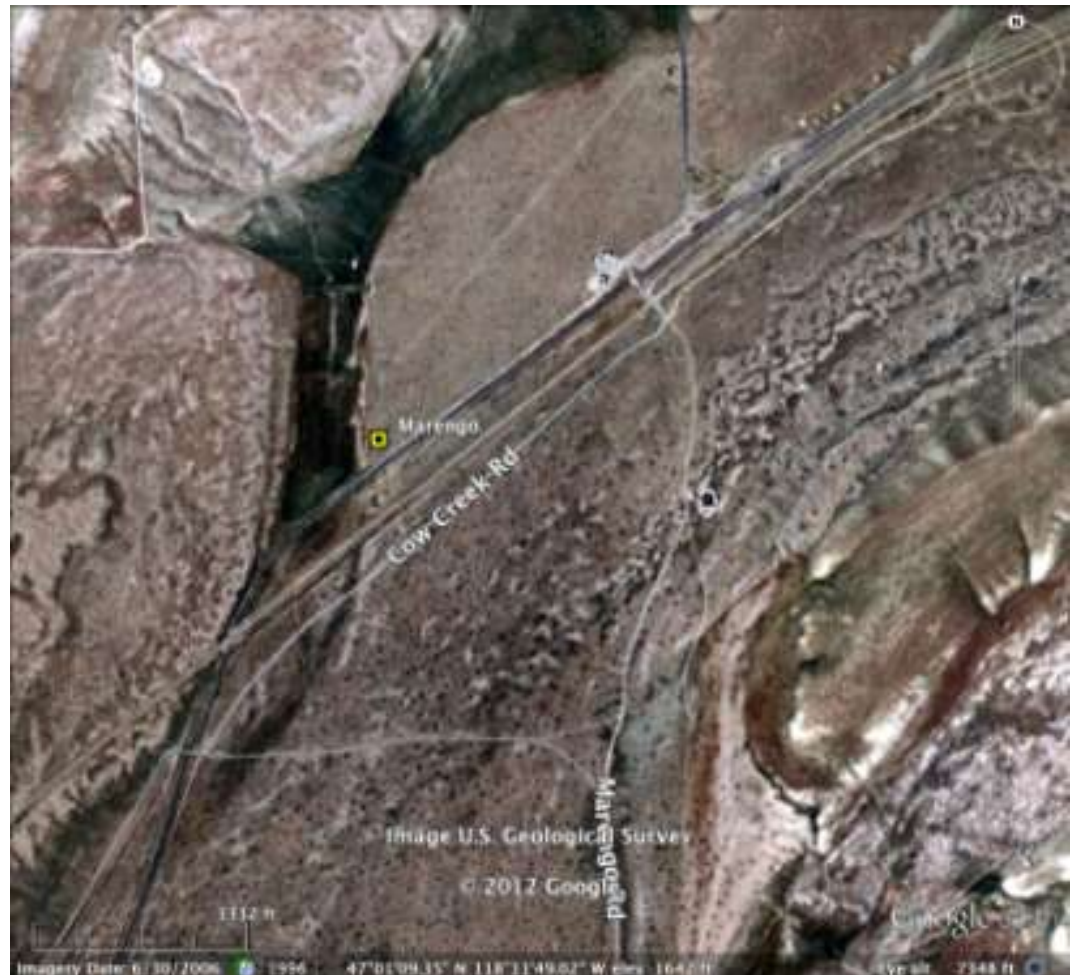

Figure 62 Location of the Marengo field site near Ritzville, Washington.

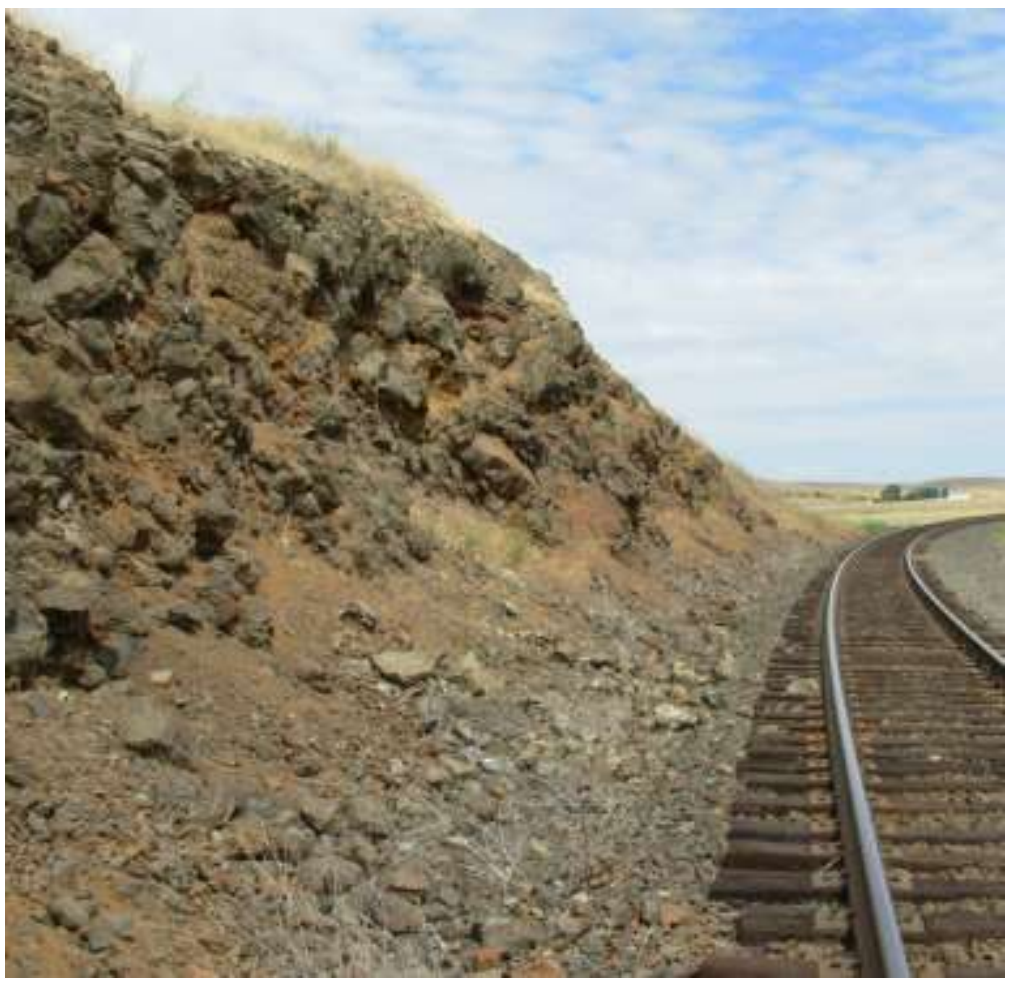

Figure 63 Marengo railroad cut. Only weathered basalt was found here. 
The Marengo site is located off Marengo Road $0.14 \mathrm{~km}$ north of its intersection with Cow Creek Road (Figure 62). The GPS coordinates for this site are N 47.02021389 latitude and W -118.2009667 longitude; the elevation is $493.5 \mathrm{~m}$. The site was referenced by Baker and Nummedal (1978) as having an exposure of two older flood gravel sequences separated by layers of loess. Burns and Medley visited the site and found highly weathered basalt bedrock but no gravels (Figure $63)$.

\subsubsection{Macall (Benge, Washington)}

The Macall outcrop is located $4.5 \mathrm{~km}$ east of Harder Road, northwest of Benge, Washington (Figure 64). The GPS coordinates for this site are N 46.9323907 latitude and $\mathrm{W}-118.141931$ longitude; the elevation is $507.2 \mathrm{~m}$.

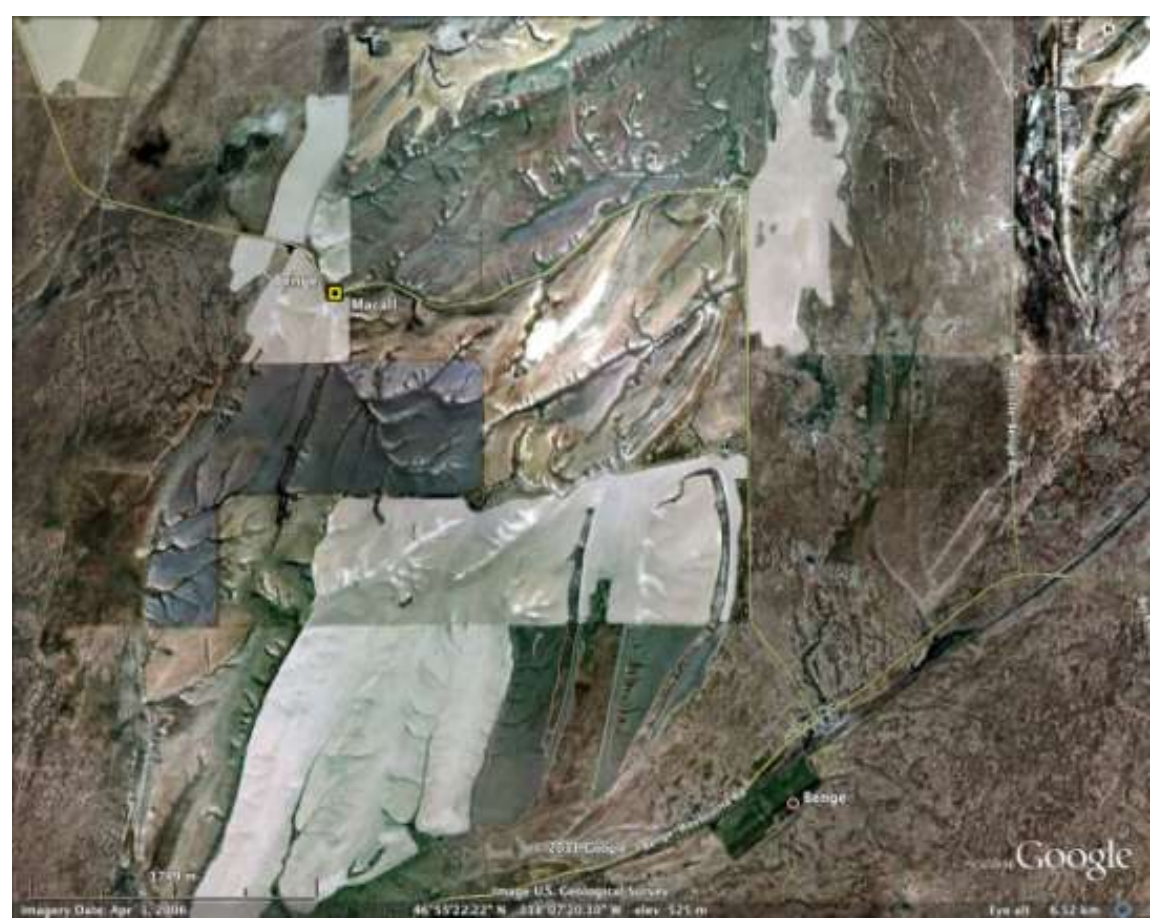

Figure 64 Location of the Macall field site, northwest of Benge, Washington. 


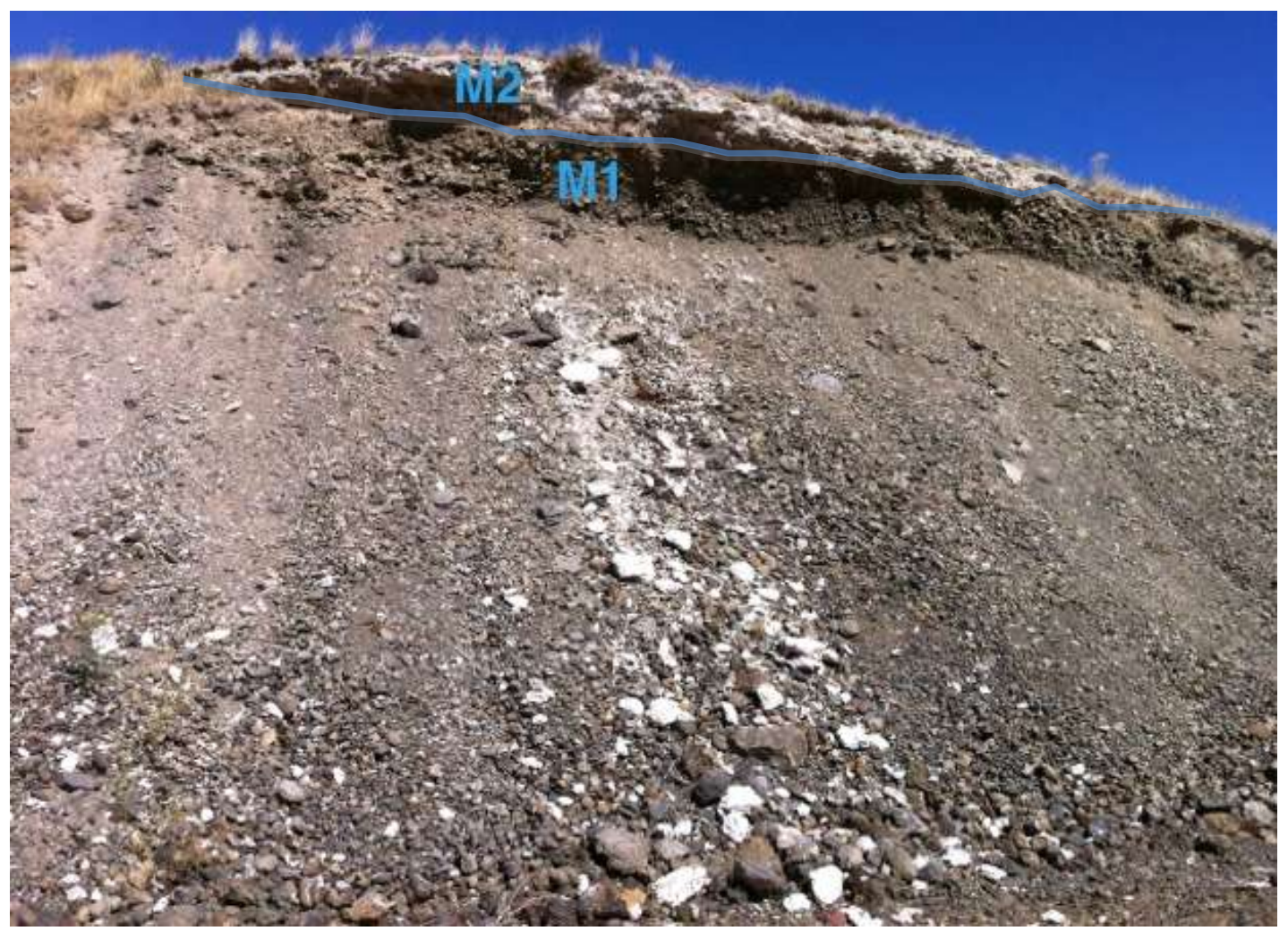

Figure 65 Macall outcrop with sample location labeled.

The site has one gravely flood deposit overlain by a calcrete paleosol (Figure 65). Sample M2 was collected in the top layer of the outcrop from the calcrete paleosol and measures $28.60 \% \pm 1.65 \mathrm{CaCO}_{3}$, Stage III development (Table 18). Below the paleosol lies a gravel-dominated flood flood deposit composed of basalt gravels, sample M1. Bjornstad et al. (2001) measured "reversed-polarity soil over flood gravels capped by calcrete dated at >350 ka." The flood deposit is at least 790,000 years old, Early Pleistocene.

Table 18 Chittick results for Macall site.

\begin{tabular}{|l|cc|}
\hline \multicolumn{1}{|c|}{ Sample ID } & $\begin{array}{c}\text { Average } \mathrm{CaCO}_{3} \\
\text { Percent }\end{array}$ & $\begin{array}{c}\text { Stage of } \\
\text { Development }\end{array}$ \\
\hline $\begin{array}{l}\text { M2 calcrete paleosol } \\
\text { in flood gravels }\end{array}$ & $28.60 \pm 1.65$ & Stage III \\
\hline
\end{tabular}




\subsubsection{Revere (Benge, Washington)}

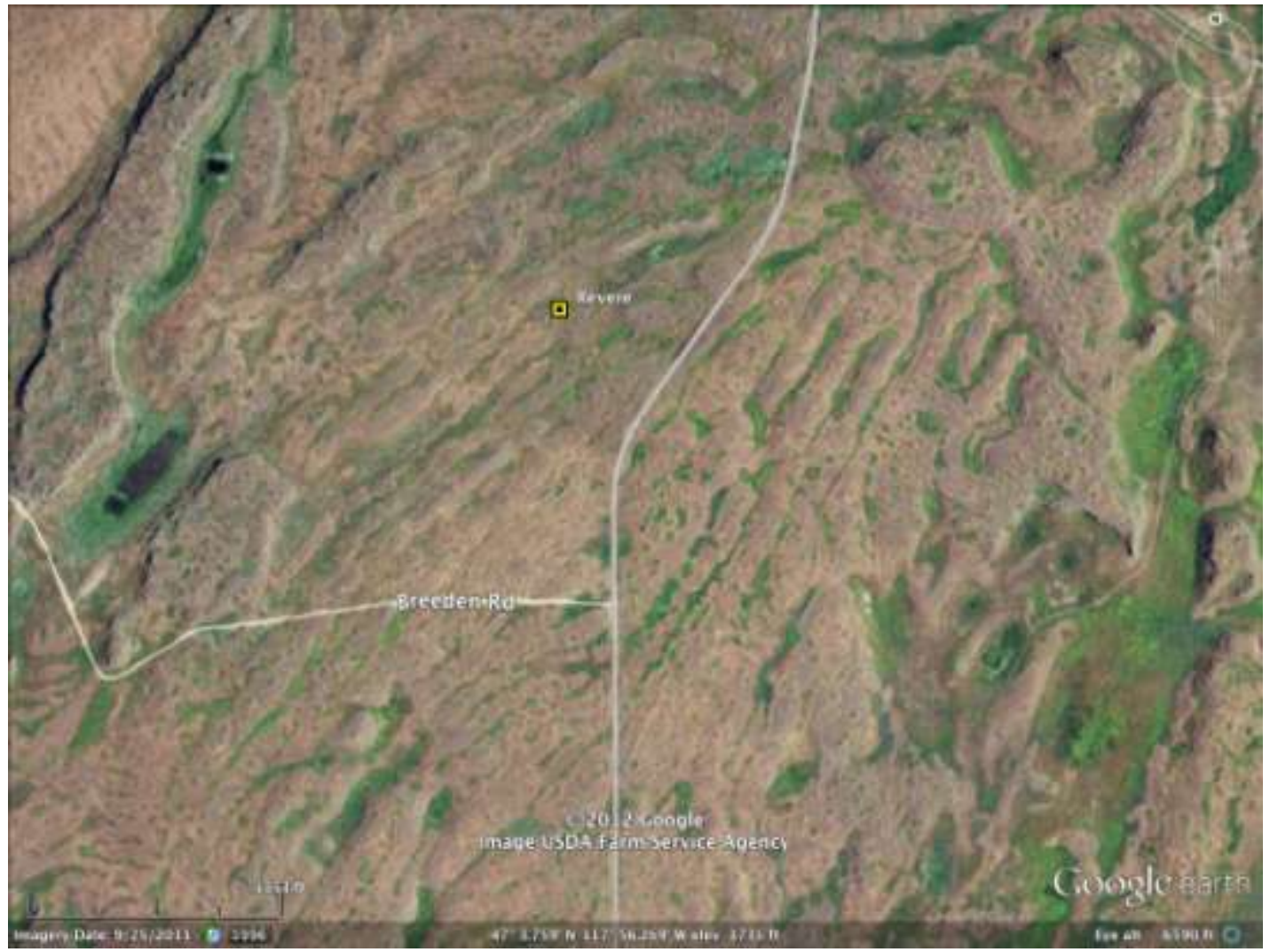

Figure 66 Location of the Revere field site near Benge, Washington.

Revere is located at the intersection of Breeden Road (also called Gering Road) and Revere Road. The GPS coordinates for this site are N 47.0647264 latitude and W -117.939204 longitude; the elevation is $512 \mathrm{~m}$. Four layers are described here: RV1 gravel flood deposit, RV2 calcrete paleosol in flood gravels, RV2A loess, RV3 calcrete paleosol formed in loess.

Baker and Nummedal (1978), Patton and Baker (1978), and Bjornstad et al. (2001) interpret two flood-scoured unconformities in Palouse Loess with reversed magnetic polarity measured in layer RV2A. Layer RV1 is a gravelly flood deposit with primarily basalt clasts. 


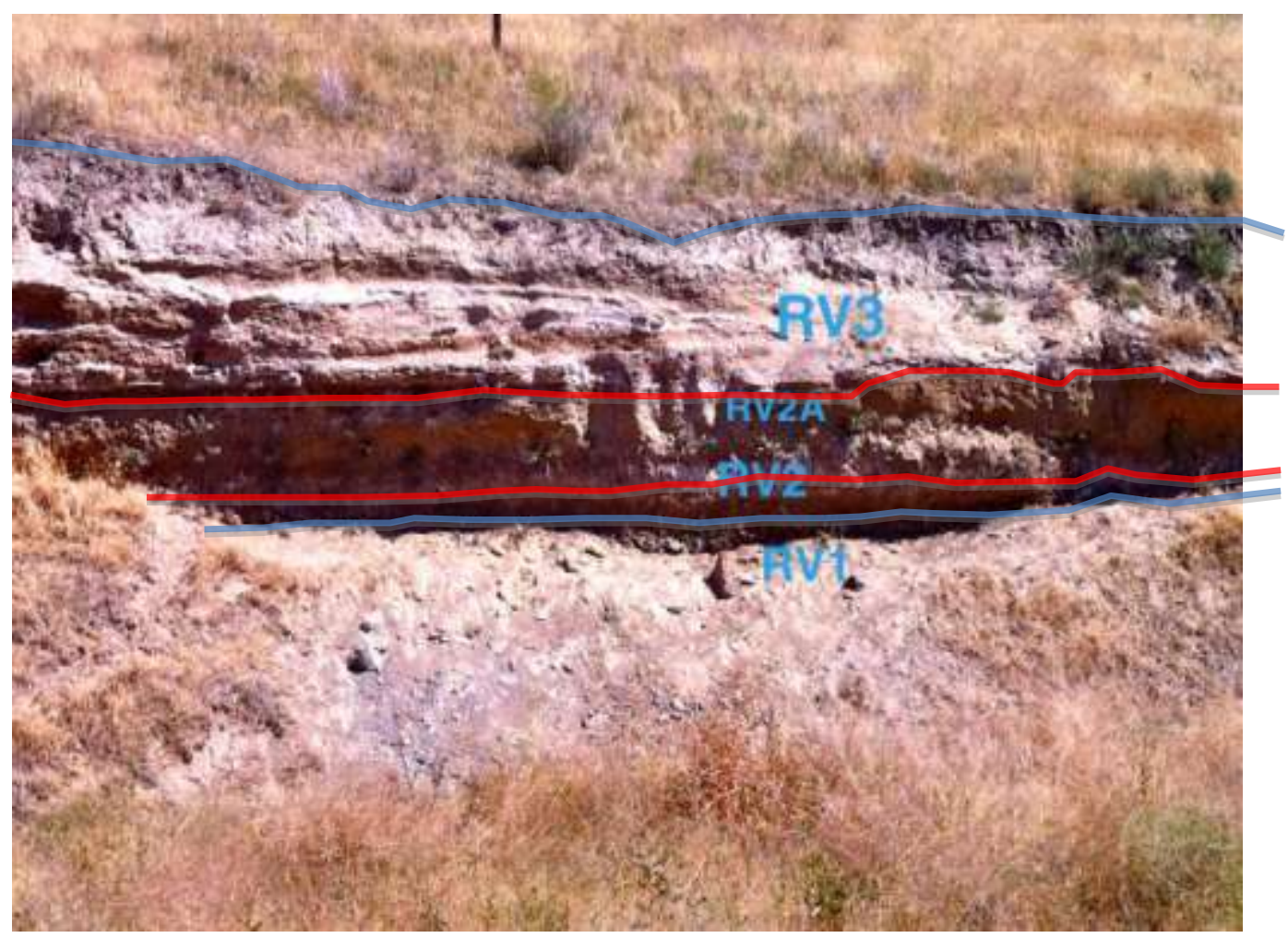

Figure 67 Revere outcrop with sample locations labels.

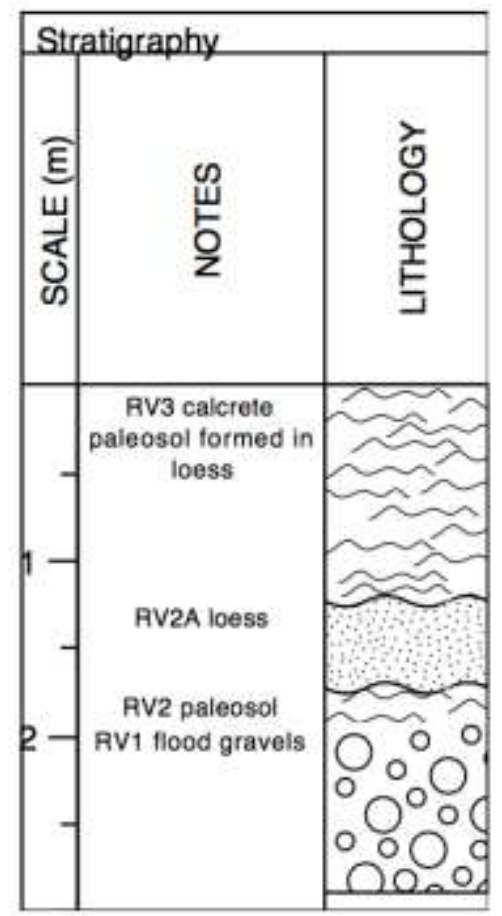

Figure 68 Stratigraphy of Revere outcrop. 
A thin calcrete paleosol, RV2, caps the gravel layer. Sample RV3 was taken in the upper calcrete paleosol layer containing basalt pebbles. Lenses of fine-grained silt are also present in RV3. A layer of loess, RV2A, is located between the two calcrete paleosols, separated by two unconformities. I interpret RV1 to be an Early Pleistocene flood deposit and the flood cut unconformities as Middle Pleistocene.

\subsubsection{Leslie Road (Richland, Washington)}

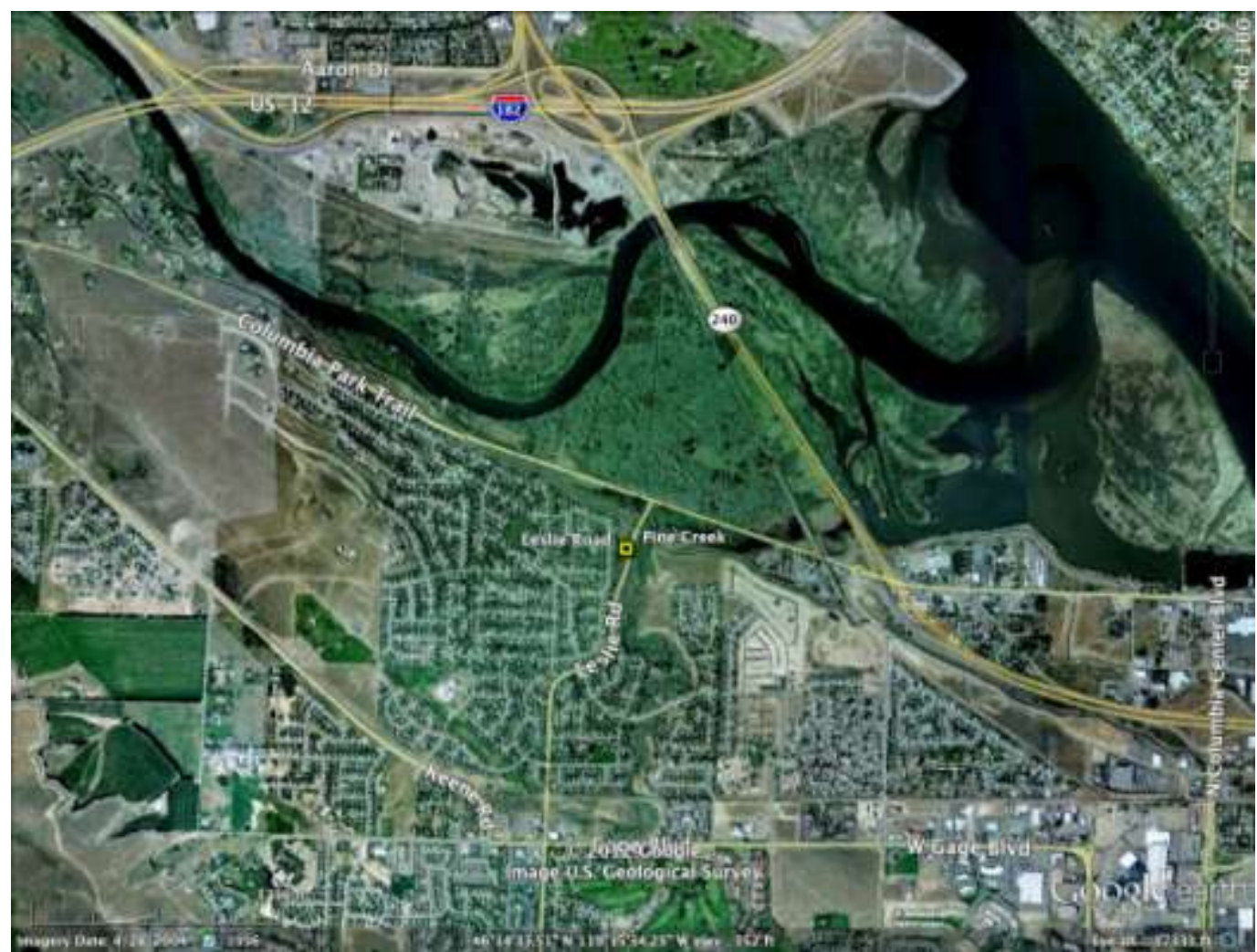

Figure 69 Location of the Leslie Road field site, near Richland, Washington.

Leslie Road is located $3.7 \mathrm{~km}$ southeast from Highway 12 off of Columbia Park Trail (Figure 69). The GPS coordinates for this site are N 46.23969907 latitude and W -119.2598591 longitude; the elevation is $118 \mathrm{~m}$. Two prominent calcrete paleosols in two gravelly flood deposits are present at the outcrop (Figure 70). 


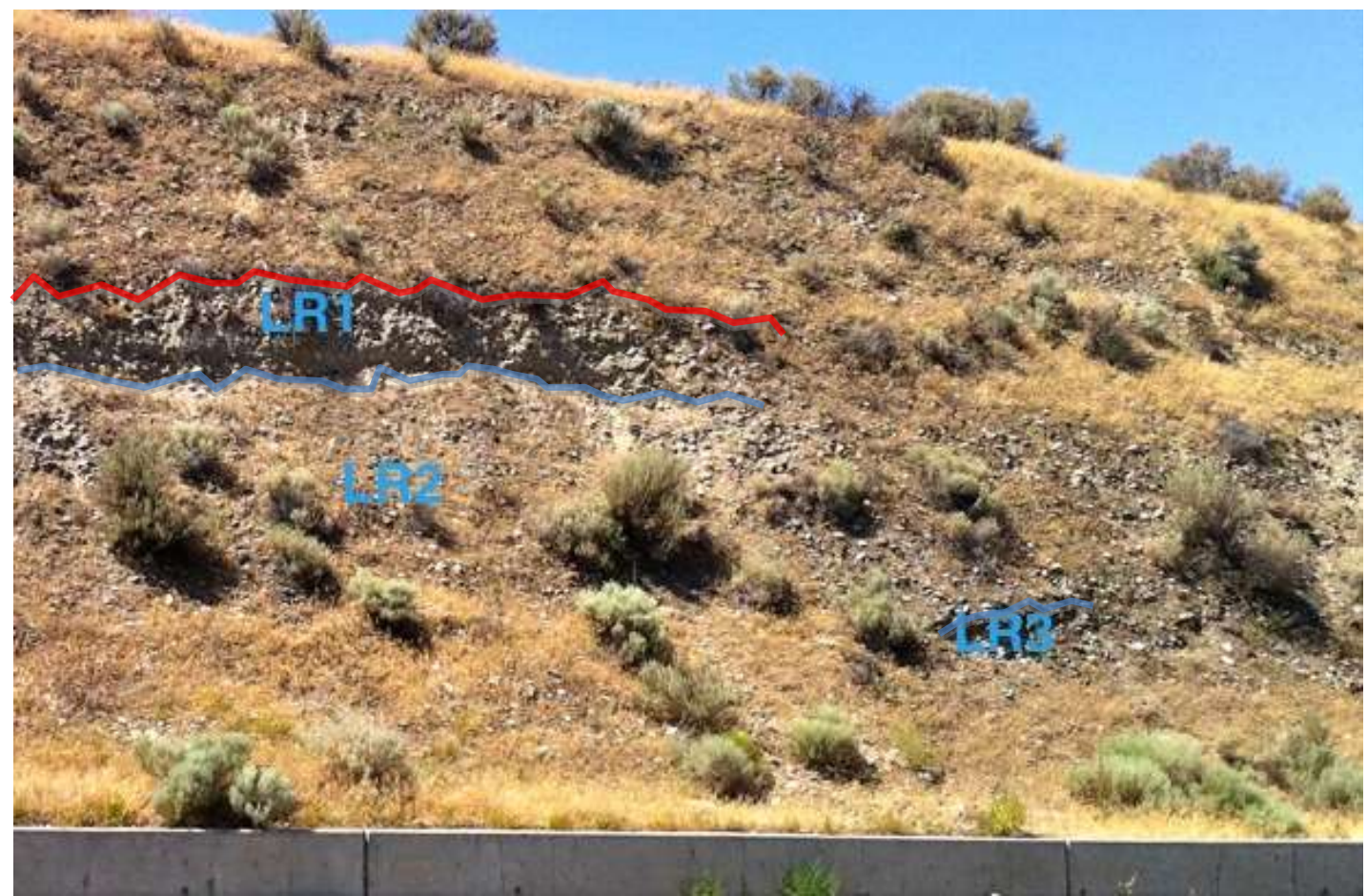

Figure 70 Leslie Road outcrop with sample locations labeled.

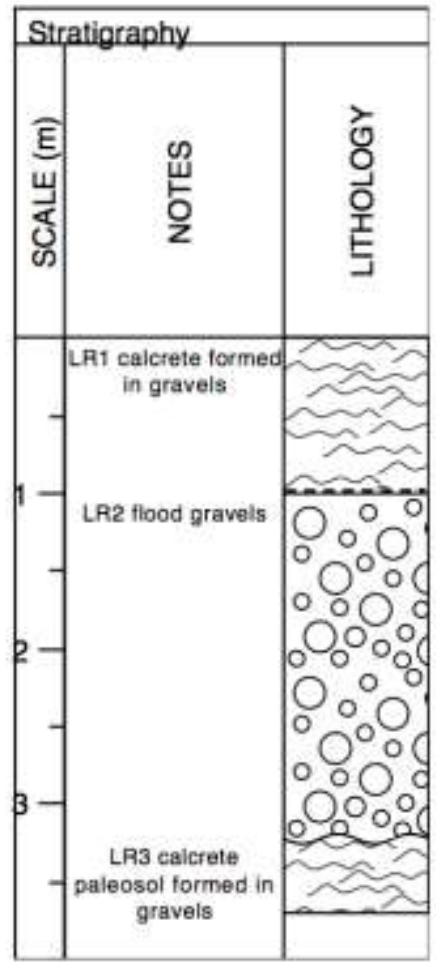

Figure 71 Stratigraphy at Leslie Road outcrop. 
Baker et al. (1991) dated the upper calcrete paleosol horizon where LR1 was sampled at a maximum age date of $>400 \mathrm{ka}$. LR1 contains $6.4 \% \pm 0.3$ percent $\mathrm{CaCO}_{3}$, Stage II development. Th/U dating at or near this locality from the eastern end of Badger Coulee gives a minimum age of 0.2 Ma for the calcrete cap (Baker et al., 1991). The gravelly flood deposit that underlies the upper calcrete cap, sample LR2, contains many exotic clasts including granites, schists, and quartzites (Figure 72). I interpret LR2 as a Middle Pleistocene Flood deposit. Another much thinner discontinuous calcrete paleosol, sample LR2, lies approximately 4.6 to 6 meters below LR1. Sample LR3 measured $16.5 \% \pm 1.1 \mathrm{CaCO}_{3}$, Stage II+ development (Table 19). More flood gravels containing exotic clasts lie below the lower paleosol, and I interpret them as Early Pleistocene in age.

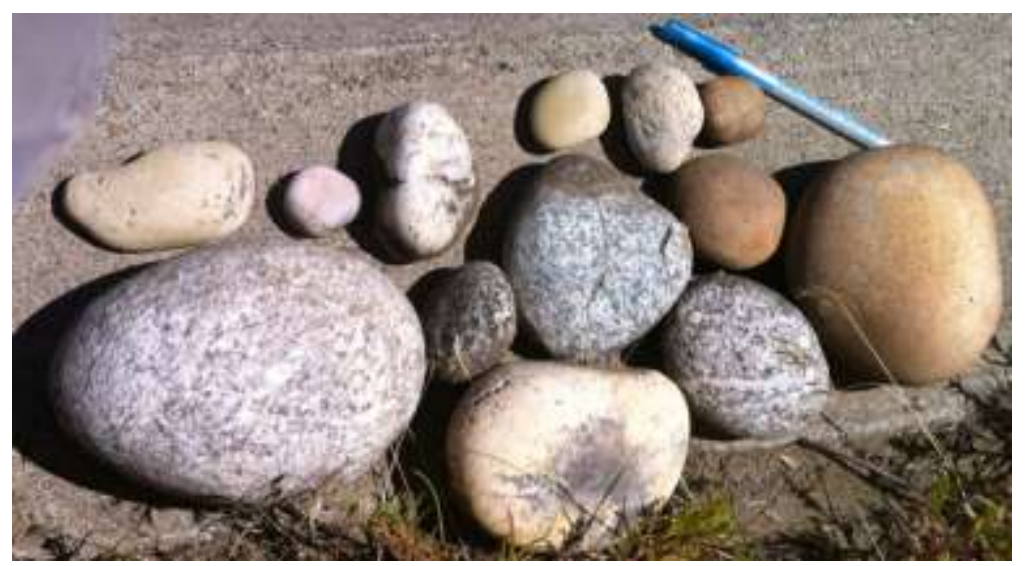

Figure 72 Exotic clasts from the gravelly flood deposit LR2 at Leslie Road outcrop.

Table 19 Chittick results for Leslie Road site.

\begin{tabular}{|l|cc|}
\hline \multicolumn{1}{|c|}{ Sample ID } & $\begin{array}{c}\text { Average } \mathrm{CaCO}_{3} \\
\text { Percent }\end{array}$ & $\begin{array}{c}\text { Stage of } \\
\text { Development }\end{array}$ \\
\hline $\begin{array}{l}\text { LR1 calcrete paleosol } \\
\text { in flood gravels }\end{array}$ & $6.4 \pm 0.3$ & Stage II \\
\hline LR2 flood gravels & $0.1 \pm 0.3$ & Stage I \\
\hline $\begin{array}{l}\text { LR3 calcrete paleosol } \\
\text { in flood gravels }\end{array}$ & $16.5 \pm 1.1$ & Stage II+ \\
\hline
\end{tabular}




\subsubsection{Fuels Materials and Examination Facility (FMEF) (Richland, Washington)}

The Fuels Materials and Examination Facility site was not visited due to its

prohibited access on the Hanford site in Washington (Figure 73). Baker et al. (1991) found three plane-laminated sand sequences that “...possibly correlate with Early, Middle, and Late Pleistocene flood episodes, discussed above for coarse-grained flood deposits.

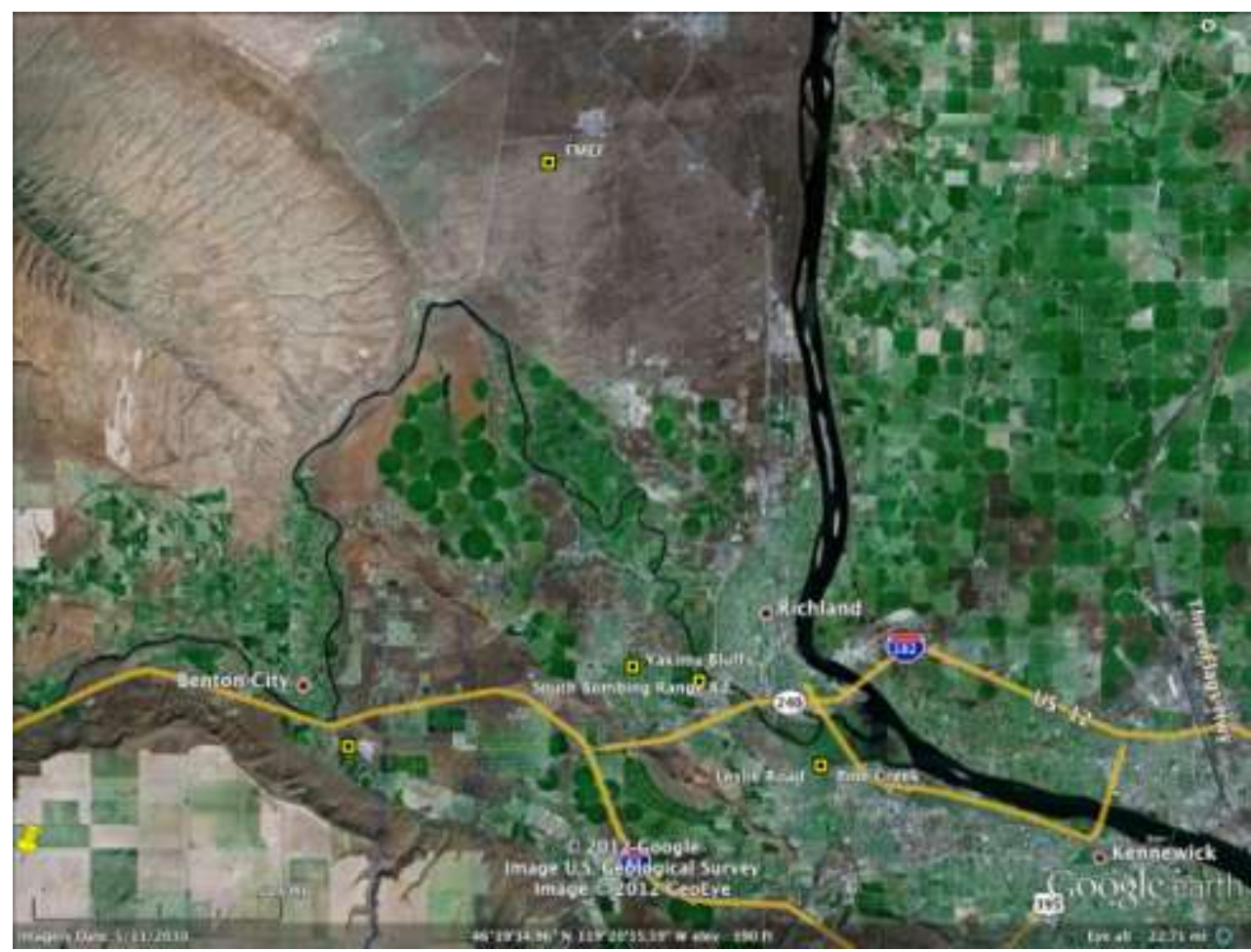

Figure 73 Location of the FMEF field site, north of Richland, Washington.

The uppermost unit contains the Mount St. Helens set S tephra couplet dated at about 15.4 ka calendar years (Mullineaux et al., 1978). The two lower planelaminated sand sequences bear paleosols with weakly developed and bioturbated B horizons, suggesting distinctly different ages. Additional evidence for three separate 
flood episodes includes clastic dikes in the lower and middle units which are truncated at their upper contacts (Baker et al., 1991).

\subsubsection{South Bombing Range Road (West Richland, Washington)}

The South Bombing Range Road field site is located along Bombing Range Road approximately $0.8 \mathrm{~km}$ north of Keene Road (Figure 74). The GPS coordinates for this site are $\mathrm{N} 46.26969907$ latitude and W -119.34279 longitude; the elevation is $174.7 \mathrm{~m}$. Bjornstad et al. (2001) found "normally magnetized soil over flood gravel with a calcrete cap." Scott Burns and I did not find the field site described. We believe this field site has been turned into a park, and the visible features have been covered with fill.

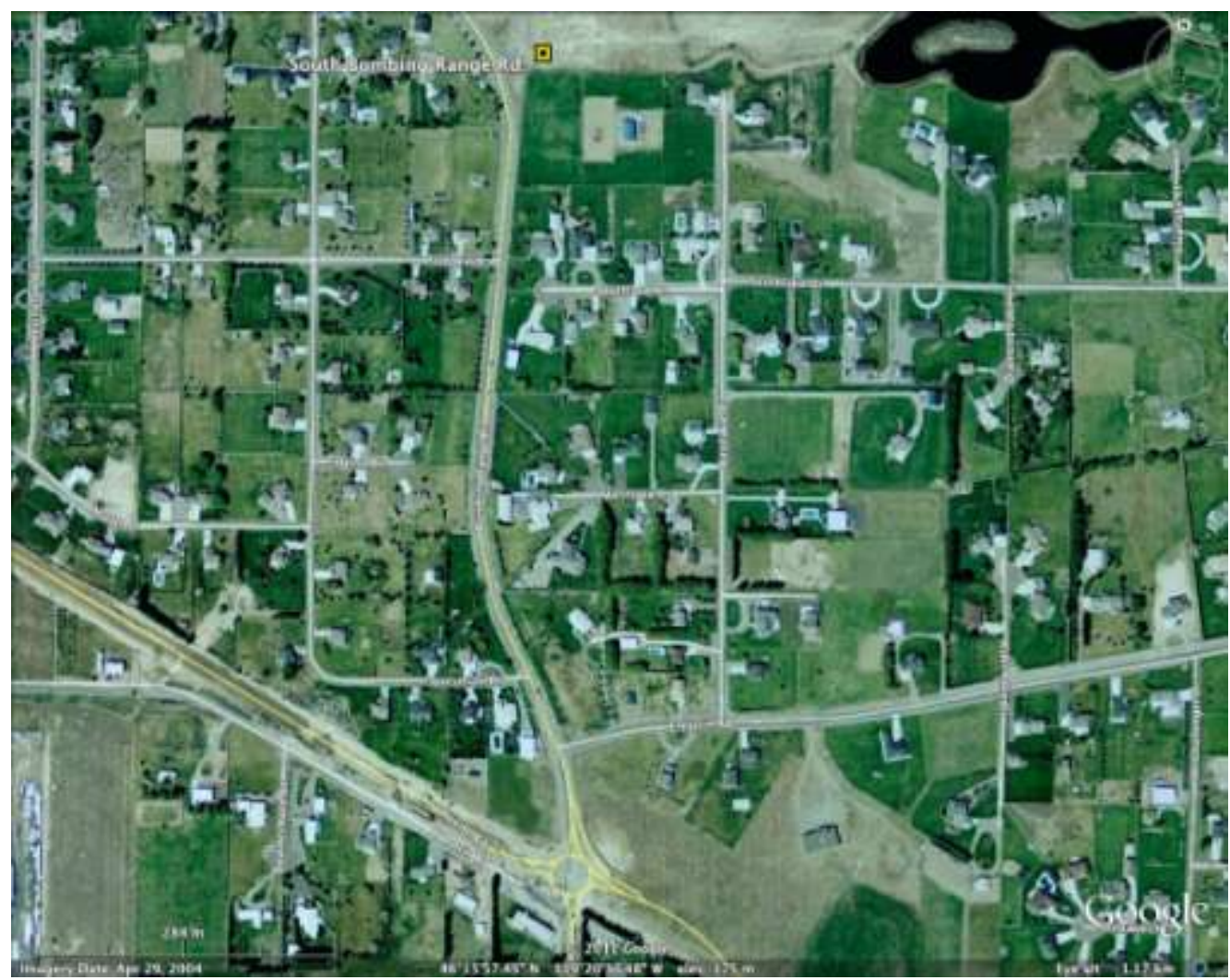

Figure 74 Location of the South Bombing Range Road field site. 


\subsubsection{Yakima Bluffs (Richland, Washington)}

The Yakima Bluffs field site is located above the present day Yakima River on private property at the north end of Truman Road where the road dead ends (Figure 75). Truman Road can be accessed from Exit 3 on Highway 182. The GPS coordinates for this site are N 46.26531216 latitude and W -119.3133526 longitude; the elevation is $148.7 \mathrm{~m}$. The site contains a minimum of 12 ancient flood rhythmites (Figure 79) capped by old flood gravels (Figure 76).

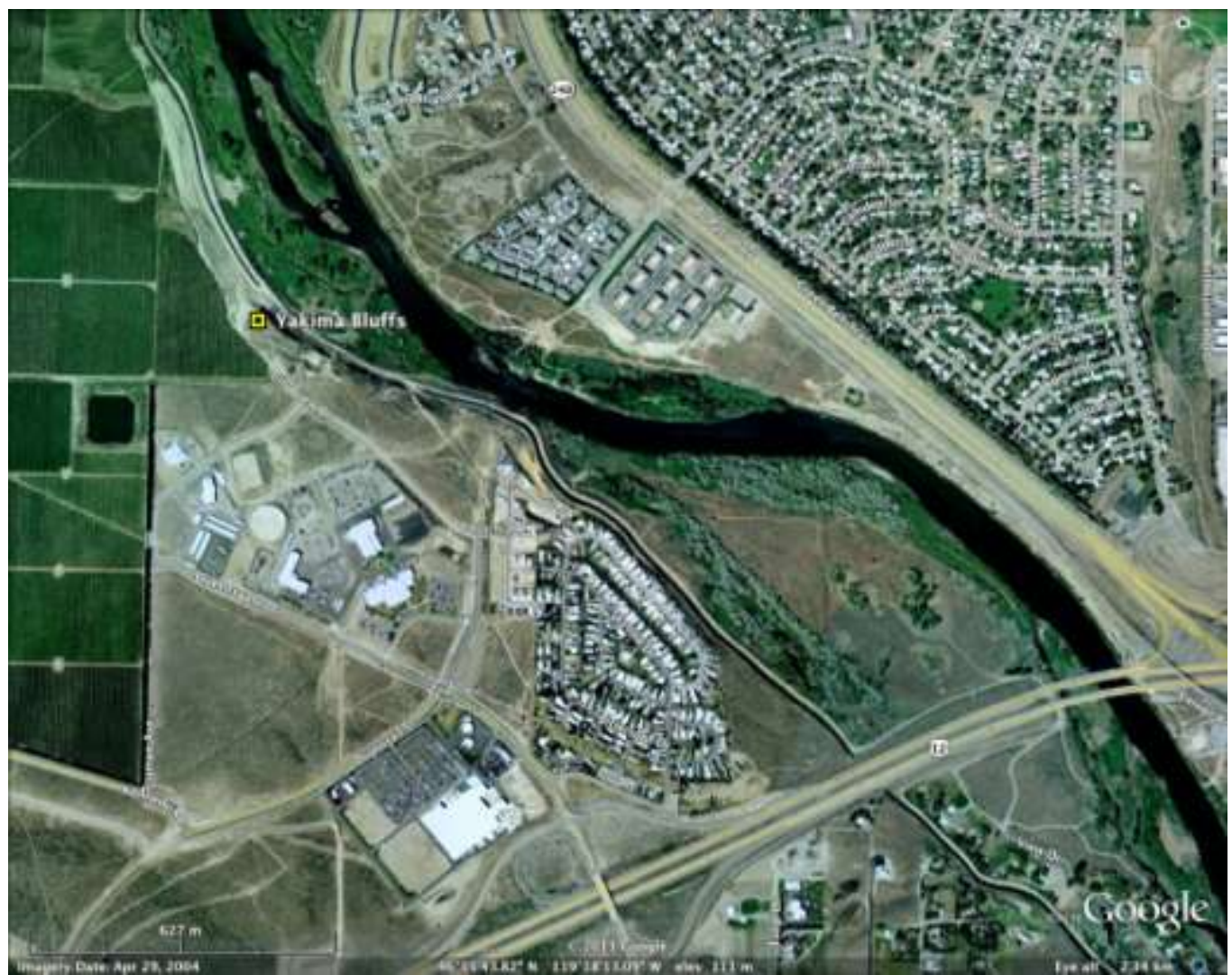

Figure 75 Location of the Yakima Bluffs field site near Richland, Washington.

Yakima Bluffs has been studied by Baker et al. (1991), Fecht et al. (1999), Bjornstad et al. (2001), and Bjornstad (2006). Bjornstad (2006) found "at least two layers of gravel-dominated flood deposits...[15.24 m] or more below the 
surface...Fine-grained sediments sampled from the lower layer exhibit reversed magnetic polarity, while the younger layers above show normal magnetic polarity." High energy floods coming through this area eventually jammed the coulee and caused the Yakima River to be diverted north (Bjornstad, 2006). The subsequent deposits overlying the gravels are low energy slackwater rhythmites. However, more gravels unconformably overlie the sequence of at least 12 thick rhythmites at the site (Figure 78).

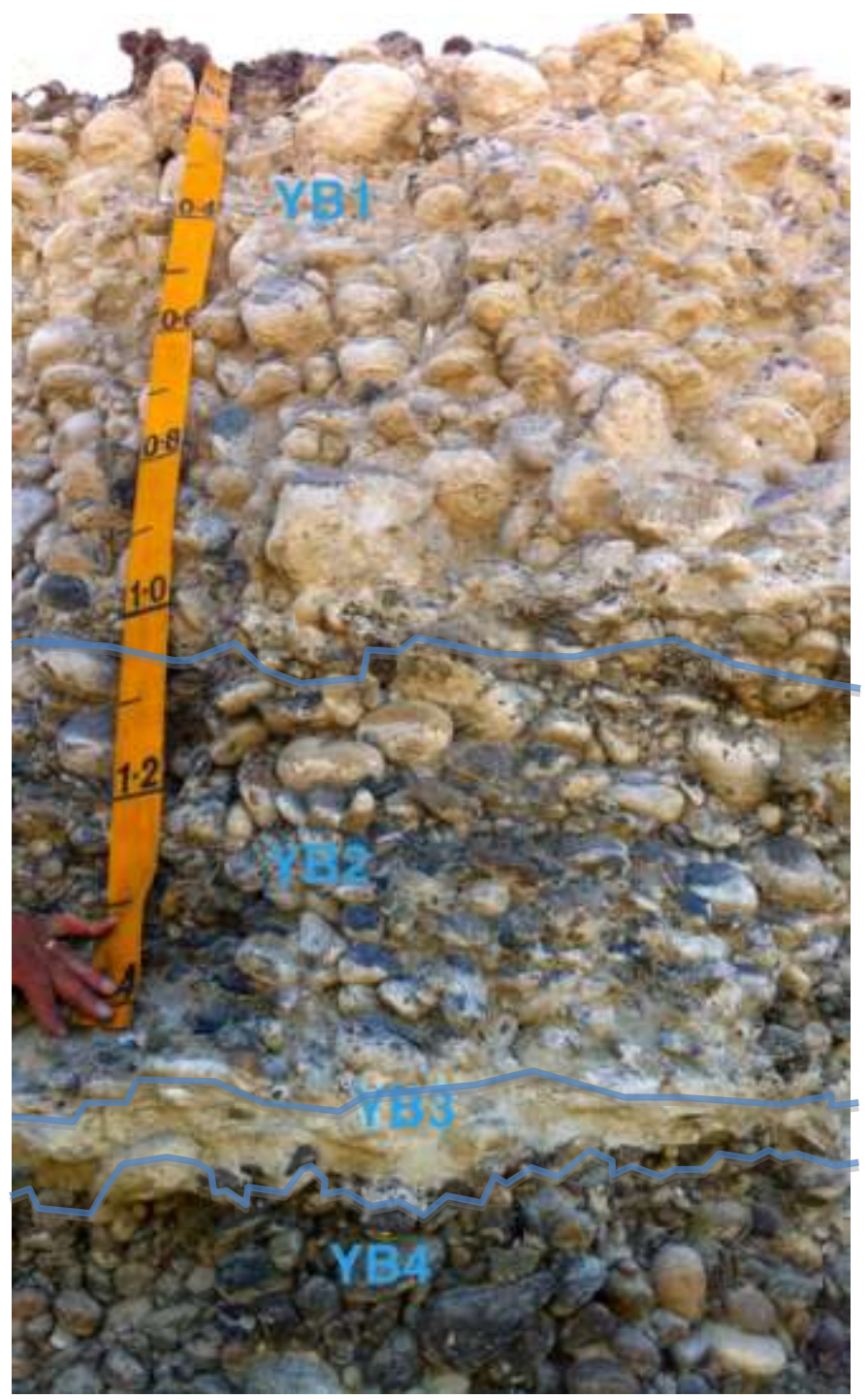

Figure 76 Yakima Bluffs outcrop, upper gravels; sample locations labeled. 


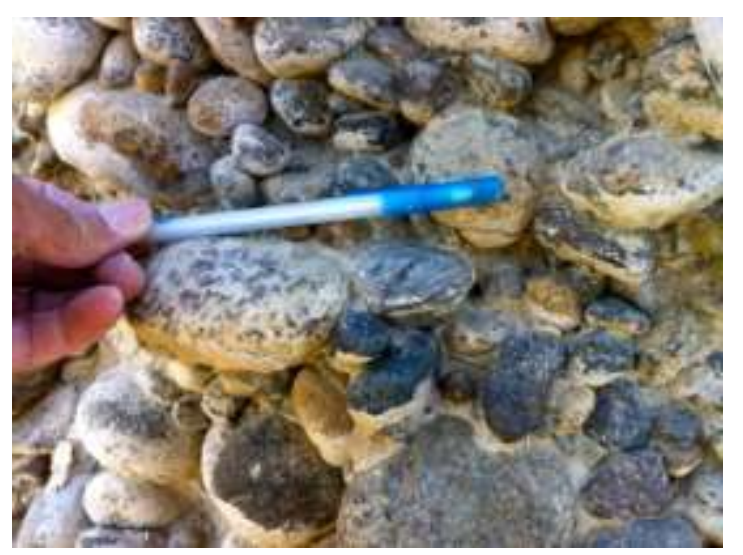

Figure 77 Exotic clasts in the gravel-dominated flood deposits at Yakima Bluffs outcrop.

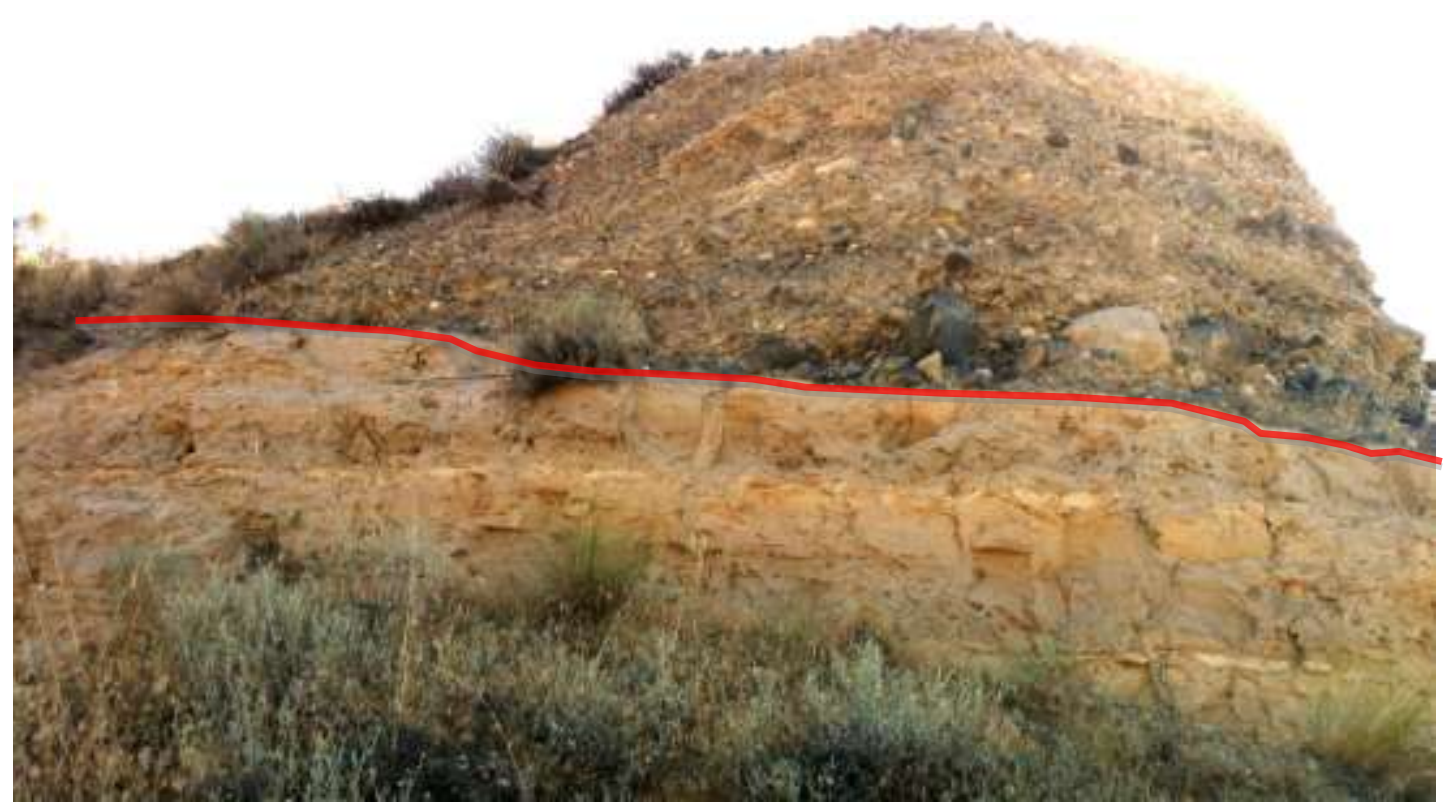

Figure 78 Unconformable contact between flood gravels and slackwater rhythmites at Yakima Bluffs outcrop.

Sample YB1, containing $21.3 \% \pm 2.6 \mathrm{CaCO}_{3}$ and Stage III calcrete development, was collected from the uppermost gravelly calcrete paleosol (Figure 76) (Table 20). YB2 was collected from the gravel-dominated flood deposit underlying the paleosol and contains $8.7 \% \pm 0.4 \mathrm{CaCO}_{3}$, Stage II development. YB3 was collected from a thin, very fine-grained calcrete deposit in the flood gravels and contained 22.6\% $\pm 1.6 \mathrm{CaCO}_{3}$, Stage III development. YB4 $\left(1.2 \% \pm 0.2 \mathrm{CaCO}_{3}\right.$, Stage I $)$ 
was collected below layer YB3 in flood gravels containing little or no sand, silt, or clay.

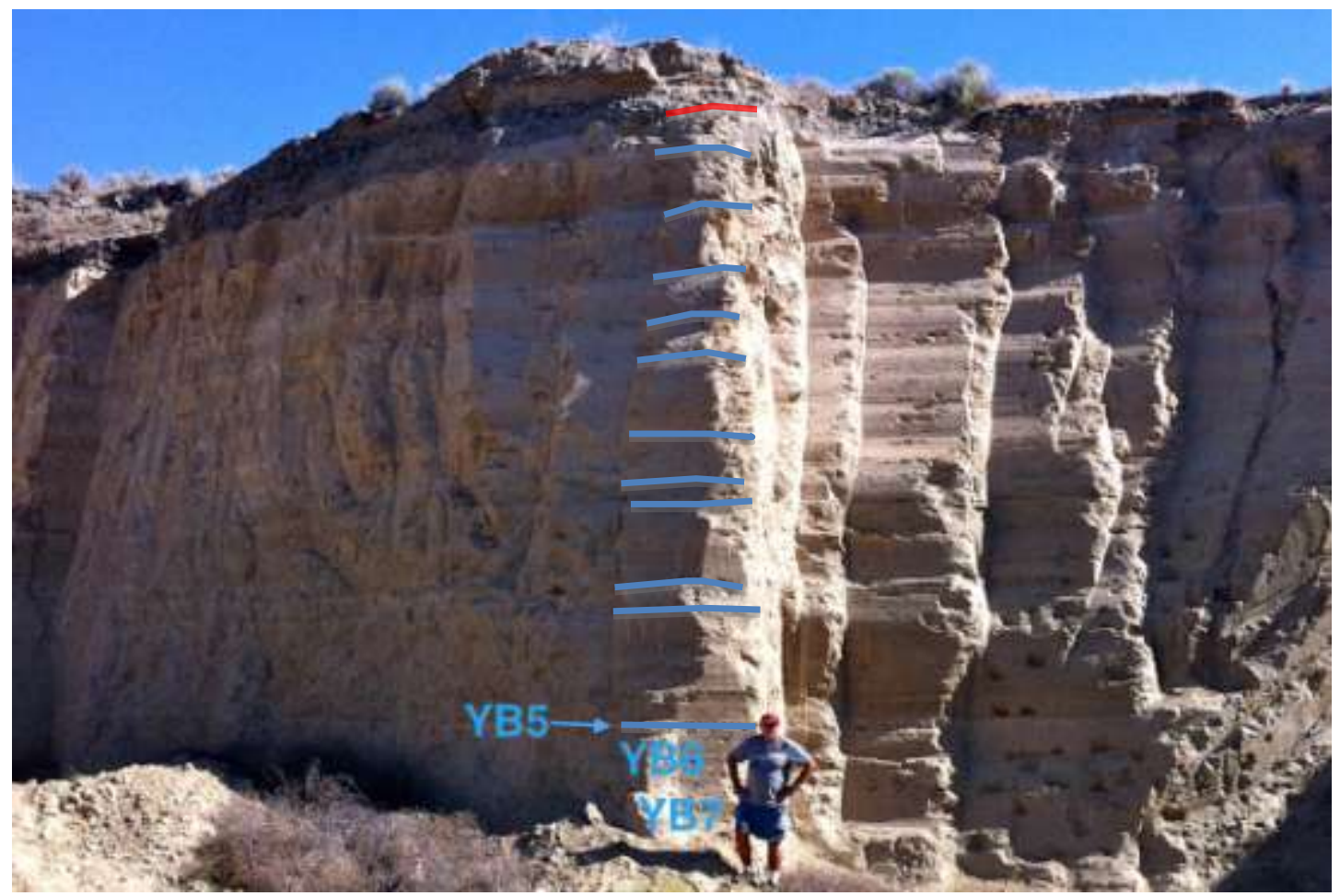

Figure 79 Yakima Bluffs outcrop with sample locations labeled.

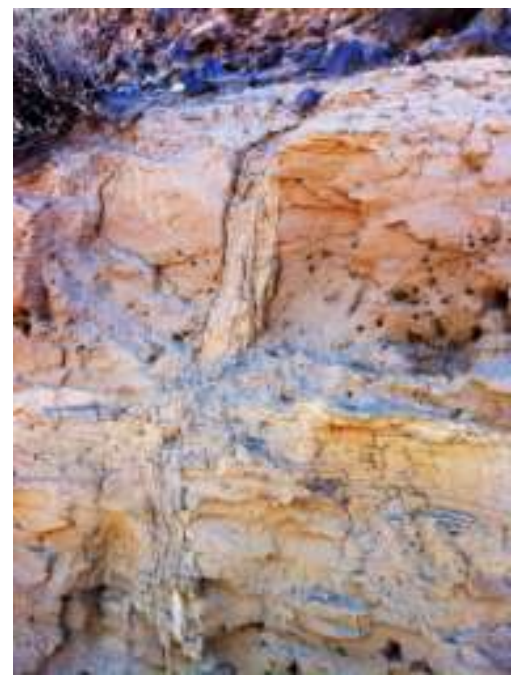

Figure 80 Clastic dikes in rhythmites at Yakima Bluffs outcrop. 
The gravels from these deposits contain many exotic clasts including granite, quartzite, and schists (Figure 77).

Samples YB7 and YB6 were taken from one of the lowermost rhythmite layers at the outcrop (Figure 79). Each rhythmite gradually coarsens upward from coarse-grained sand to silt. Sample YB5 was taken from an extremely hard, calcified silt layer at the top of the rhythmite and contains $24.9 \% \pm 2.3 \mathrm{CaCO}_{3}$. The lower sandy parts of these ancient rhythmites contain low amounts of $\mathrm{CaCO}_{3}(1.6-1.8 \%$, YB6 and YB7, Table 20). The rhythmites are probably Middle Pleistocene in age. Truncated clastic silt dikes are found throughout the section (Figure 80).

Table 20 Chittick results for Yakima Bluffs site.

\begin{tabular}{|lcc|}
\multicolumn{1}{|c|}{ Sample ID } & $\begin{array}{c}\text { Average } \mathrm{CaCO}_{3} \\
\text { Percent }\end{array}$ & $\begin{array}{c}\text { Stage of } \\
\text { Development }\end{array}$ \\
\hline $\begin{array}{l}\text { YB1 calcrete paleosol } \\
\text { in flood gravels }\end{array}$ & $21.3 \pm 2.6$ & Stage III \\
\hline YB2 flood gravels & $8.7 \pm 0.4$ & Stage II \\
\hline $\begin{array}{l}\text { YB3 calcrete paleosol } \\
\text { in flood gravels }\end{array}$ & $22.6 \pm 1.6$ & Stage III \\
\hline YB4 flood gravels & $1.2 \pm 0.2$ & Stage I \\
\hline $\begin{array}{l}\text { YB5 calcified silt } \\
\text { layer rhythmites }\end{array}$ & $24.9 \pm 2.3$ & Stage III \\
\hline $\begin{array}{l}\text { YB6 sand layer in } \\
\text { rhythmites }\end{array}$ & $1.8 \pm 0.2$ & Stage I \\
\hline $\begin{array}{l}\text { YB7 sand layer in } \\
\text { rhythmites }\end{array}$ & $1.6 \pm 0.1$ & Stage I \\
\hline
\end{tabular}




\subsubsection{Field Road (Benton City, Washington)}

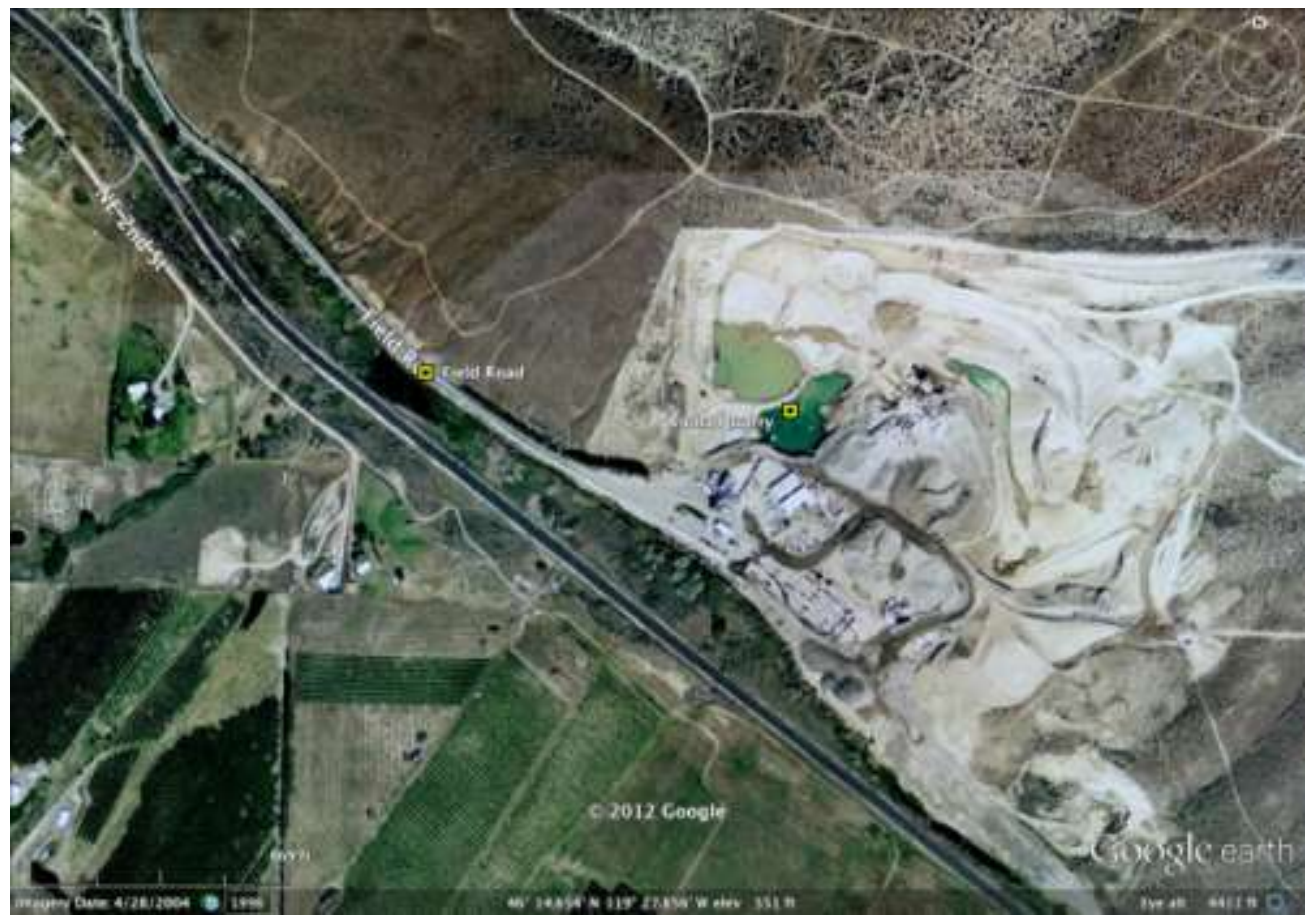

Figure 81 Location of the Field Road field site near Benton City, Washington.

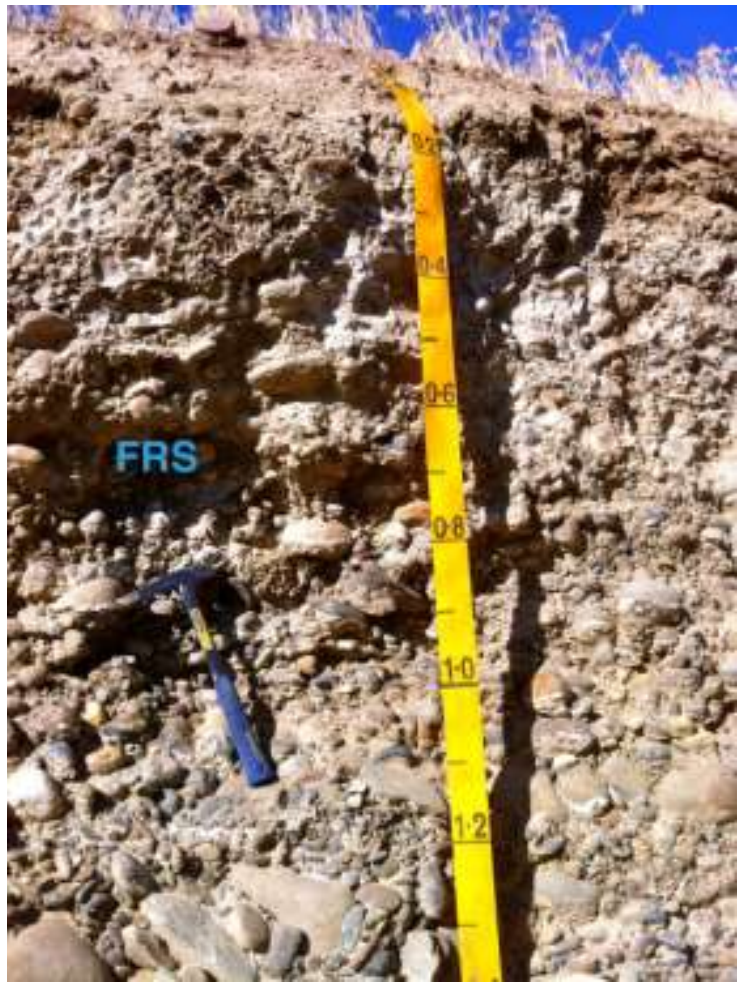

Figure 82 Field Road outcrop with sample locations labeled. 
The Field Road site is located along Field Road (Figure 81). Heading north on Highway 82, take exit 96 and then head east on Webber Road. The GPS coordinates for this site are N 46.24508872 latitude and W -119.4674443 longitude; the elevation is $165.2 \mathrm{~m}$.

The Field Road outcrop is adjacent to the "Kiona Quarry" site referenced by Baker et al (1991), Fecht et al. (1999), and Bjornstad et al. (2001). The quarry is now named "A \& B Asphalt" and could not be visited due to safety codes. Bjornstad et al. (2001) found "normally magnetized flood gravel with calcrete cap (calcrete dated at $>210$ and $>400 \mathrm{ka}$ ); oxidized flood gravels at depth." They hypothesize that there is one Middle and possibly one Early Pleistocene flood deposit at depth.

The gravel-dominated flood deposit sample collected adjacent to the quarry, FRS (Figure 82), is composed subrounded basalt gravels and measures $16.5 \% \pm 0.5$ $\mathrm{CaCO}_{3}$, Stage II+ calcrete development. It is probably Middle Pleistocene in age (Table 21).

Table 21 Chittick results for Field Rdoad site.

\begin{tabular}{|lcc|}
\hline \multicolumn{1}{|c}{ Sample ID } & $\begin{array}{c}\text { Average } \mathrm{CaCO}_{3} \\
\text { Percent }\end{array}$ & $\begin{array}{c}\text { Stage of } \\
\text { Development }\end{array}$ \\
\hline $\begin{array}{l}\text { FRS calcrete paleosol } \\
\text { in flood gravels }\end{array}$ & $16.5 \pm 0.5$ & Stage II+ \\
\hline
\end{tabular}

\subsubsection{Winans Road 1 (Walla Walla, Washington)}

The Winans Road 1 field site is located on Winans Road approximately 0.17 km east of Harvey Shaw Road (also called Cochran Road) (Figure 83). The GPS 
coordinates for this site are N 46.16667092 latitude and W -118.432645 longitude; the elevation is $286.2 \mathrm{~m}$.

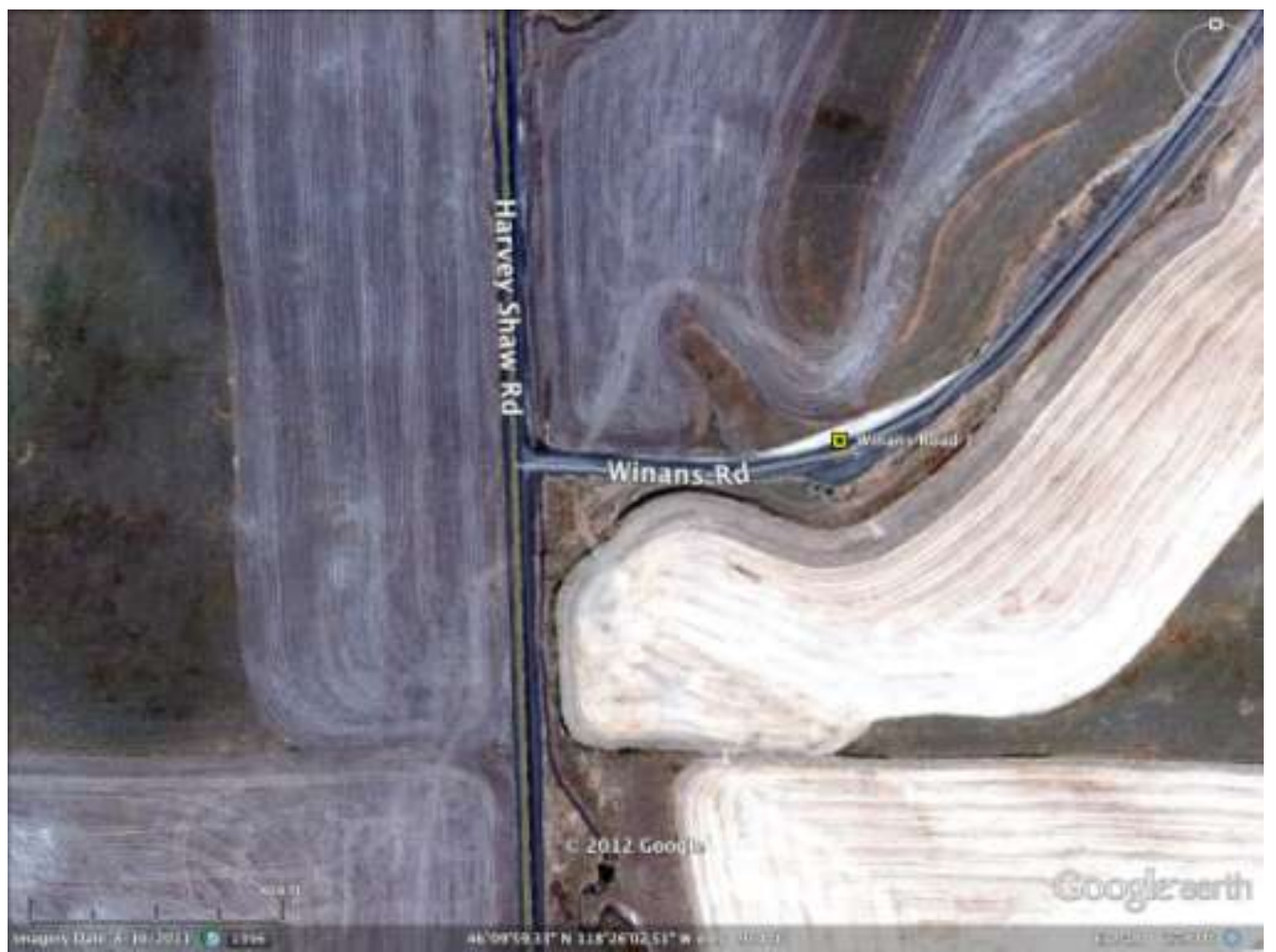

Figure 83 Location of the Winans Road 1 field site near Walla Walla, Washington.

Both Spencer and Gilk (1999) and Spencer and Jaffee (2002) interpret two pre-late Wisconsinan outburst flood deposits at this site. Three layers are described at this outcrop: WR11 slackwater deposit, WR12 calcrete paleosol in the slackwater deposit, WR12A loess layer, and WR13 diamict with calcrete paleosol.

The younger flood event, recorded by the diamict WR13, contains basaltic, granitic, and metamorphic clasts and contains $13.7 \% \pm 0.4 \mathrm{CaCO}_{3}$, Stage II+ soil development (Figure 84) (Table 22). The older flood is recorded by a slackwater deposit, WR11. Weathered basalt bedrock lies below the lower slackwater deposit. Sample WR11 contains $12.6 \% \pm 0.4 \mathrm{CaCO}_{3}$ and is capped by a calcrete paleosol, 
sample WR12 (Table 22). The paleosol contains $20.1 \% \pm 0.6 \mathrm{CaCO}_{3}$, Stage III calcrete development. A thick layer of loess, WR12A separates the calcrete paleosol and the younger diamict, separated by two unconformities. Three generations of clastic dikes are also present in all units at the outcrop. There is evidence for two floods at this site, both Middle Pleistocene.

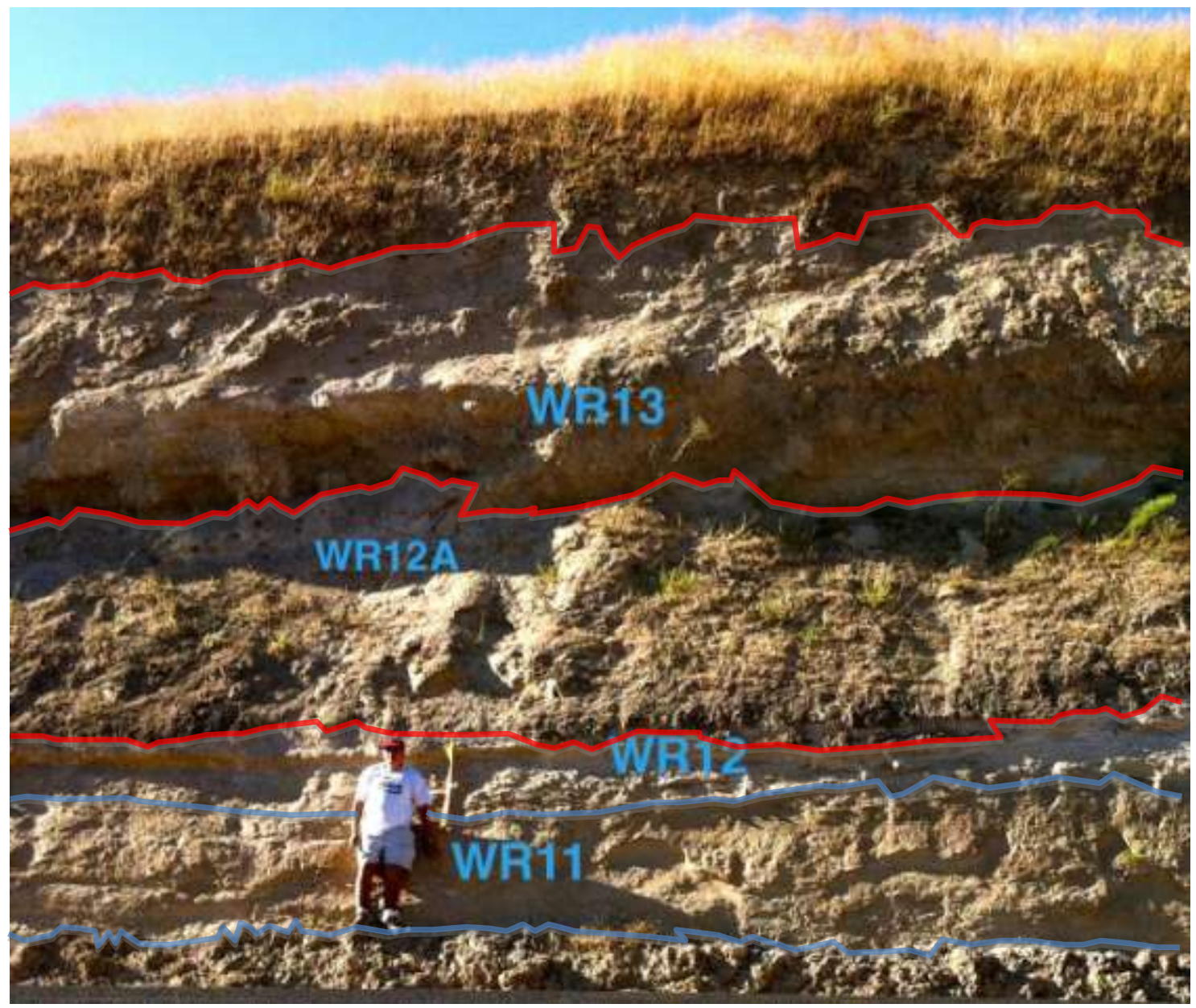

Figure 84 Winans Road 1 outcrop with sample locations labeled. 


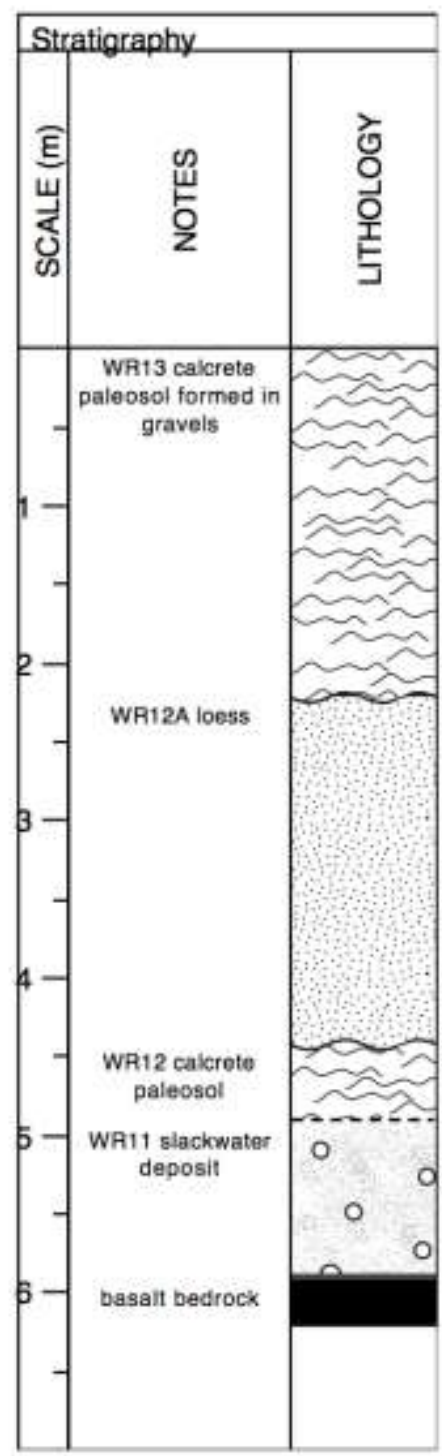

Figure 85 Stratigraphy of Winans Road 1 outcrop.

Table 22 Chittick results for Winans Road 1 site.

\begin{tabular}{|lcc|}
\hline \multicolumn{1}{|c|}{ Sample ID } & $\begin{array}{c}\text { Average } \mathrm{CaCO}_{3} \\
\text { Percent }\end{array}$ & $\begin{array}{c}\text { Stage of } \\
\text { Development } \\
\text { Stage II+ }\end{array}$ \\
\hline $\begin{array}{l}\text { WR11 slackwater } \\
\text { deposit }\end{array}$ & $12.6 \pm 0.4$ & Stage III \\
\hline $\begin{array}{l}\text { WR12 calcrete paleosol } \\
\text { in slackwater deposit }\end{array}$ & $20.1 \pm 0.6$ & Stage II+ \\
\hline $\begin{array}{l}\text { WR13 calcrete paleosol } \\
\text { in flood gravels }\end{array}$ & $13.7 \pm 0.4$ & \\
\hline
\end{tabular}




\subsubsection{Winans Road 2 (Walla Walla, Washington)}

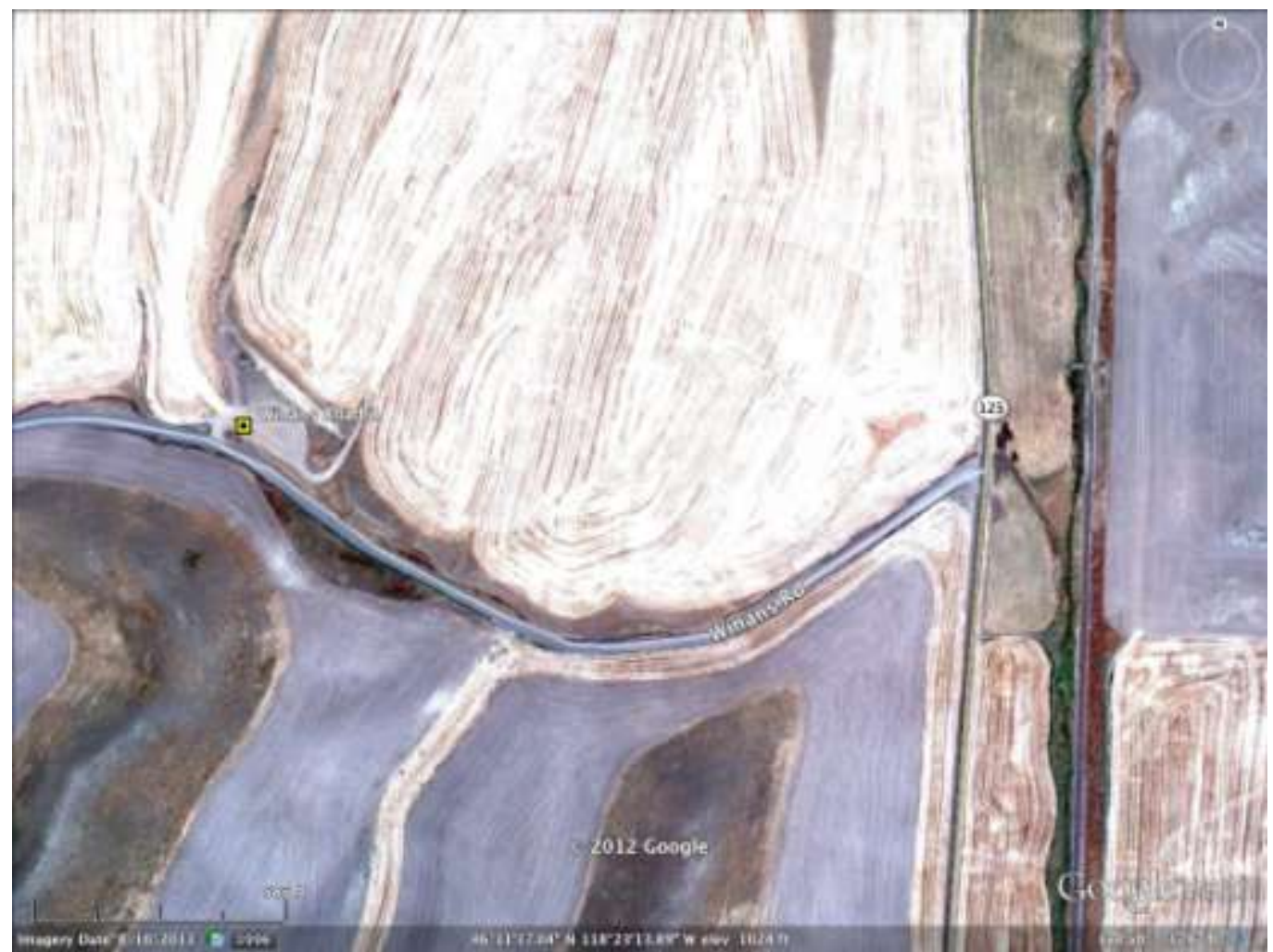

Figure 86 Location of the Winans Road 2 field site.

The Winans Road 2 field site is located $4.8 \mathrm{~km}$ northeast of Winans Road 1 along Winans Road (Figure 84). The GPS coordinates for this site are N 46.18846746 latitude and W -118.432645 longitude; the elevation is $291.1 \mathrm{~m}$. No samples were taken; the site has the same stratigraphic units as the outcrop at Winans Road 1. The lower slackwater deposit layer (WR11) overlies basalt bedrock. A rigid calcrete layer is formed on top of the slackwater deposit (WR12) We found this site, (Figure 81), when exploring in the area near Winans Road 1. I interpret the deposits as Middle Pleistocene in age. 


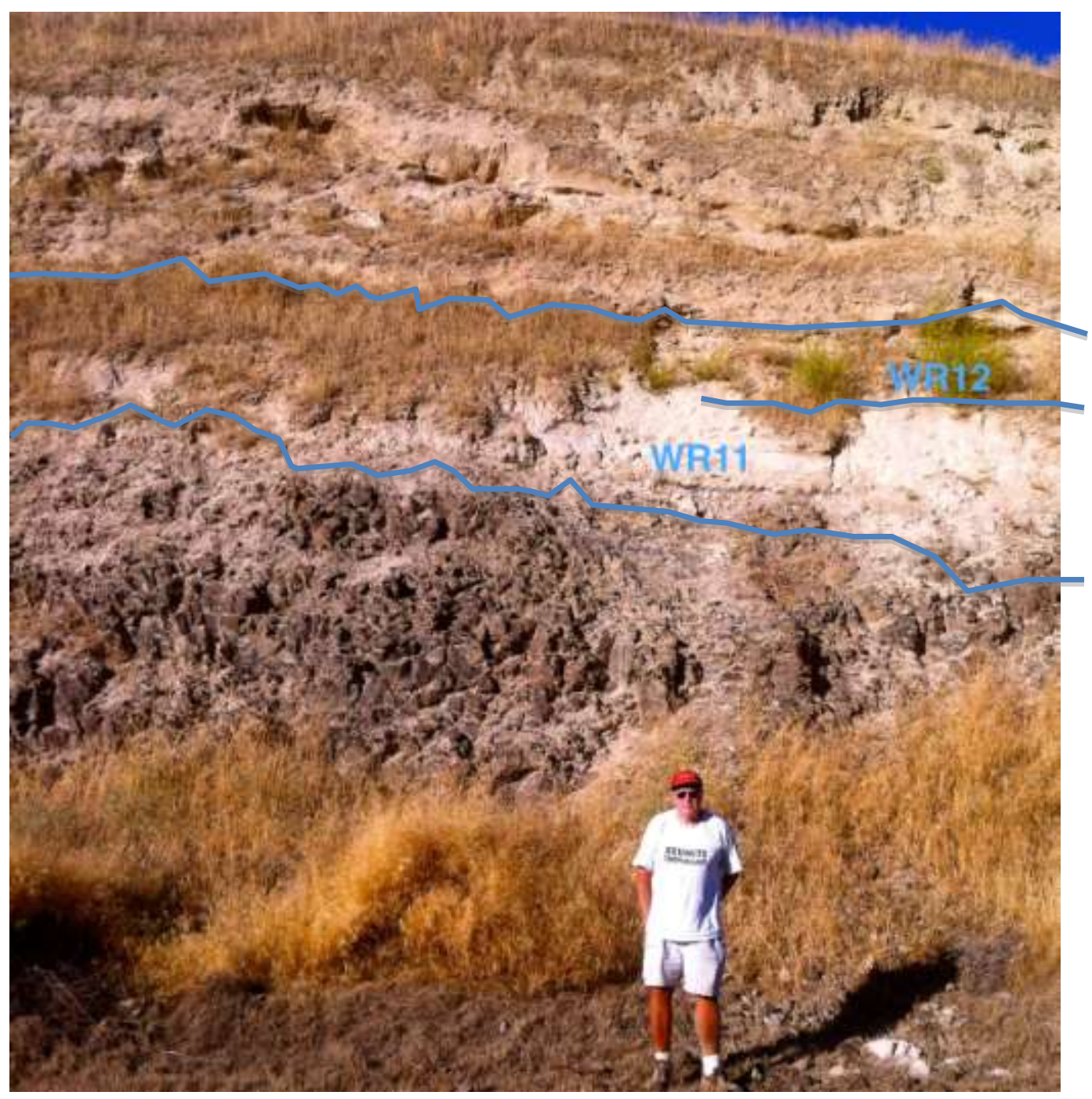

Figure 87 Winans Road 2 outcrop.

\subsubsection{Palouse Falls (Washtucna, Washington)}

The Palouse Falls field site is located along Highway 261 approximately $4 \mathrm{~km}$ southeast of Highway 260 (Figure 88). The GPS coordinates for this site are N 46.677697 latitude and W -118.37803 longitude; the elevation is $394 \mathrm{~m}$. 


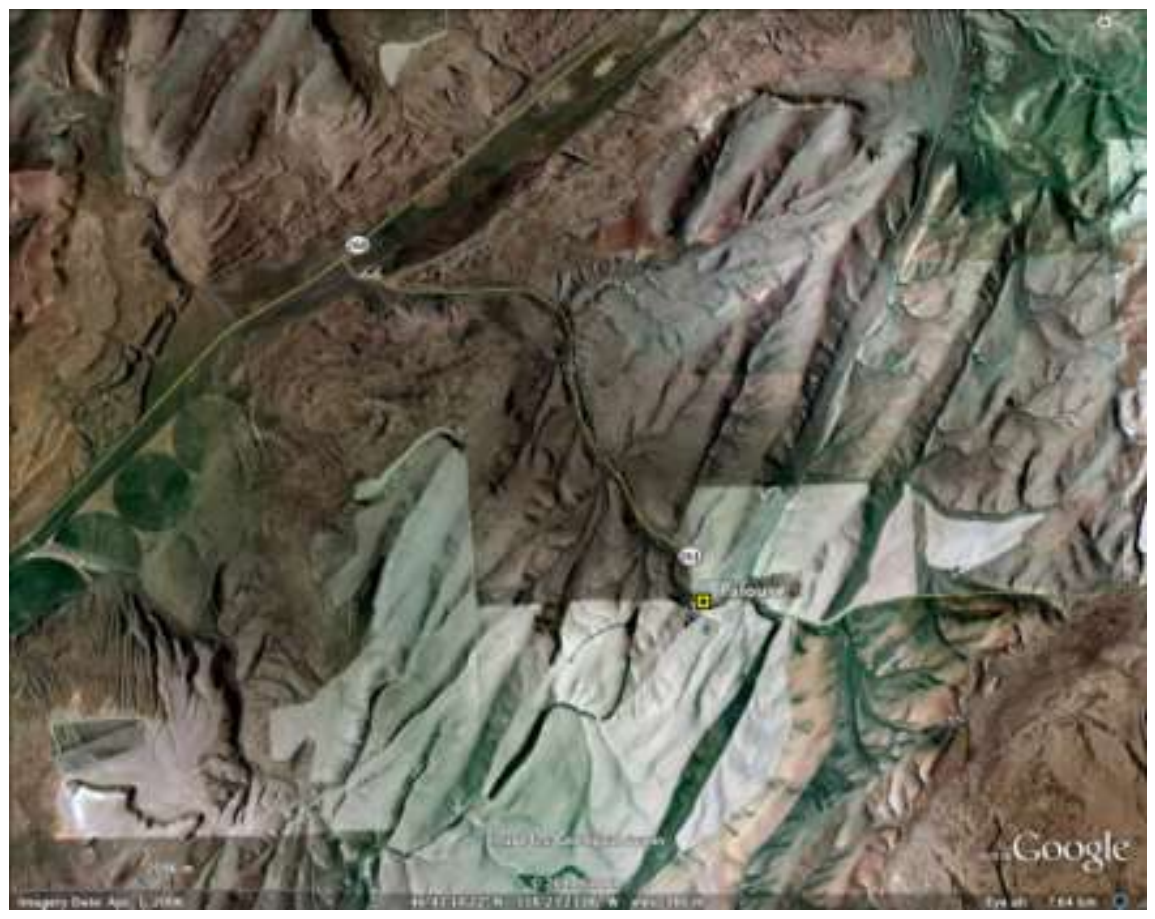

Figure 88 Location of the Palouse Falls field site.

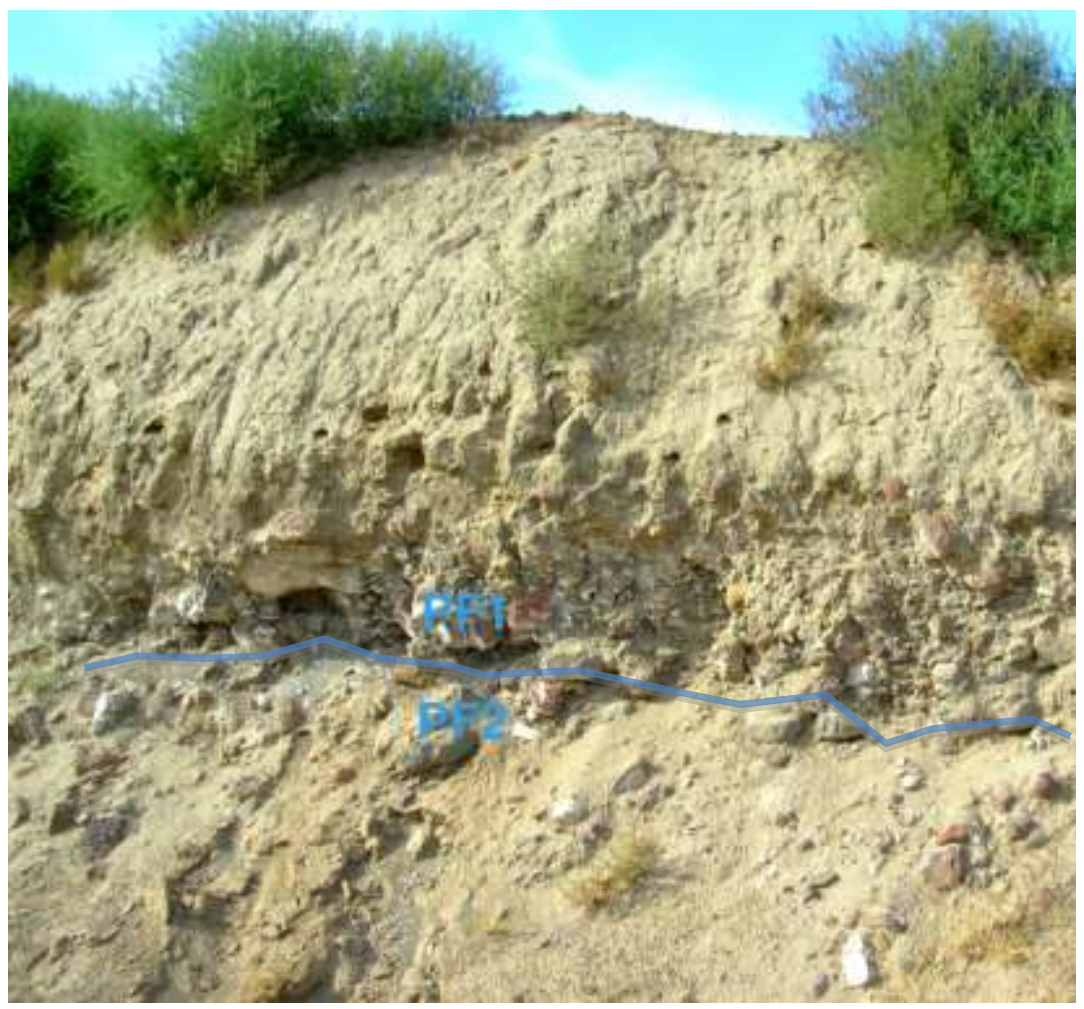

Figure 89 Palouse Falls outcrop. 


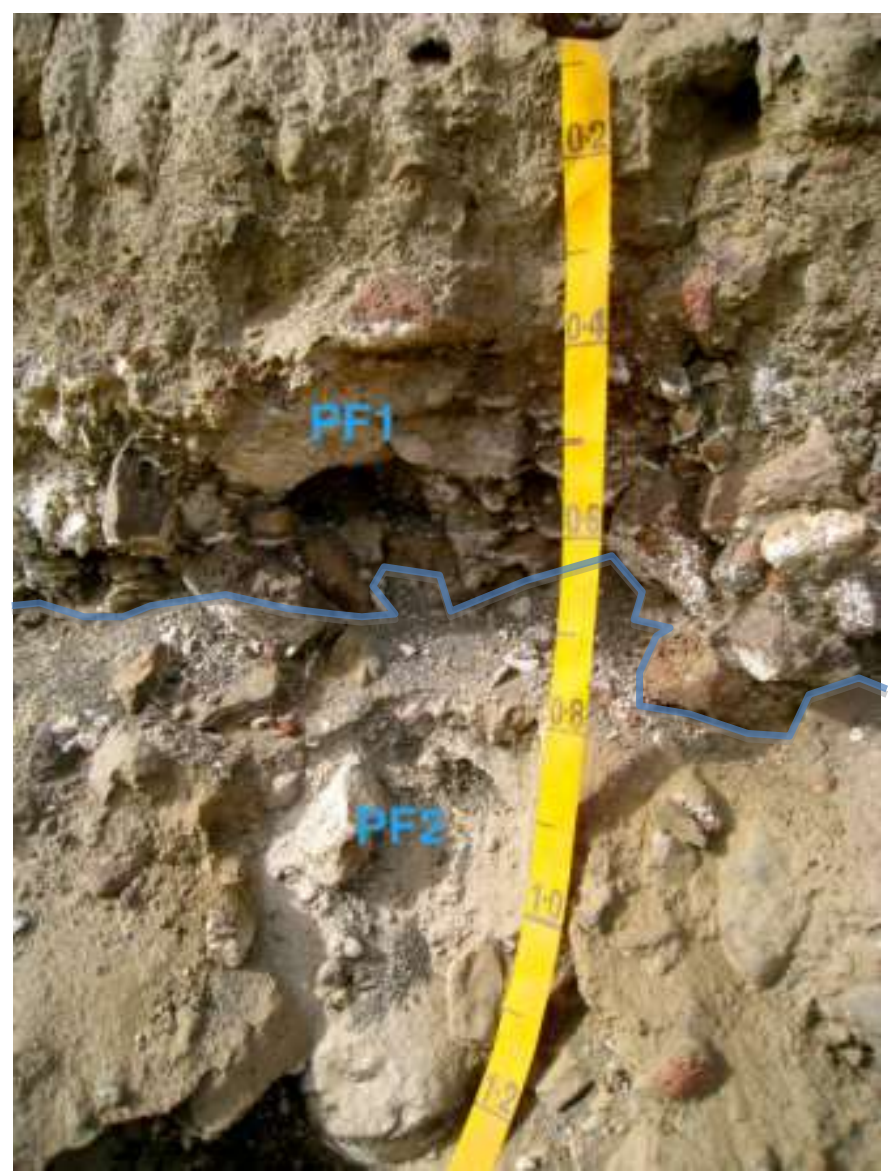

Figure 90 Palouse Falls outcrop with sample locations labeled.

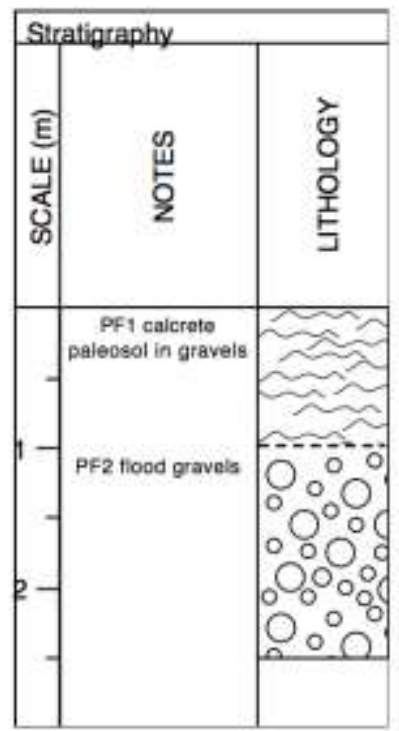

Figure 91 Stratigraphy of Palouse Falls outcrop. 
Sample PF1 is taken from a prominent and continuous calcrete layer with a lot of basalt and pumice clasts (Figure 89). Sample PF1 measured $11.43 \% \pm 0.69$ $\mathrm{CaCO}_{3}$, Stage II calcrete development (Table 23). Below the calcrete layer is a stratum of gravels with a sandy matrix. Sample PF2 was collected in these gravels underlying the calcrete and contains $1.1 \% \pm 0.1 \mathrm{CaCO}_{3}$ (Figure 90). I discovered this site, and I interpret it as being Middle Pleistocene in age.

Table 23 Chittick results for Palouse Falls site.

\begin{tabular}{|l|cc|}
\multicolumn{1}{|c|}{ Sample ID } & $\begin{array}{c}\text { Average } \mathrm{CaCO}_{3} \\
\text { Percent }\end{array}$ & $\begin{array}{c}\text { Stage of } \\
\text { Development }\end{array}$ \\
\hline $\begin{array}{l}\text { PF1 calcrete paleosol } \\
\text { in flood gravels }\end{array}$ & $11.4 \pm 0.7$ & Stage II \\
\hline PF2 flood gravels & $1.1 \pm 0.1$ & Stage I \\
\hline
\end{tabular}

\subsubsection{Canal Outcrop (Othello, Washington)}

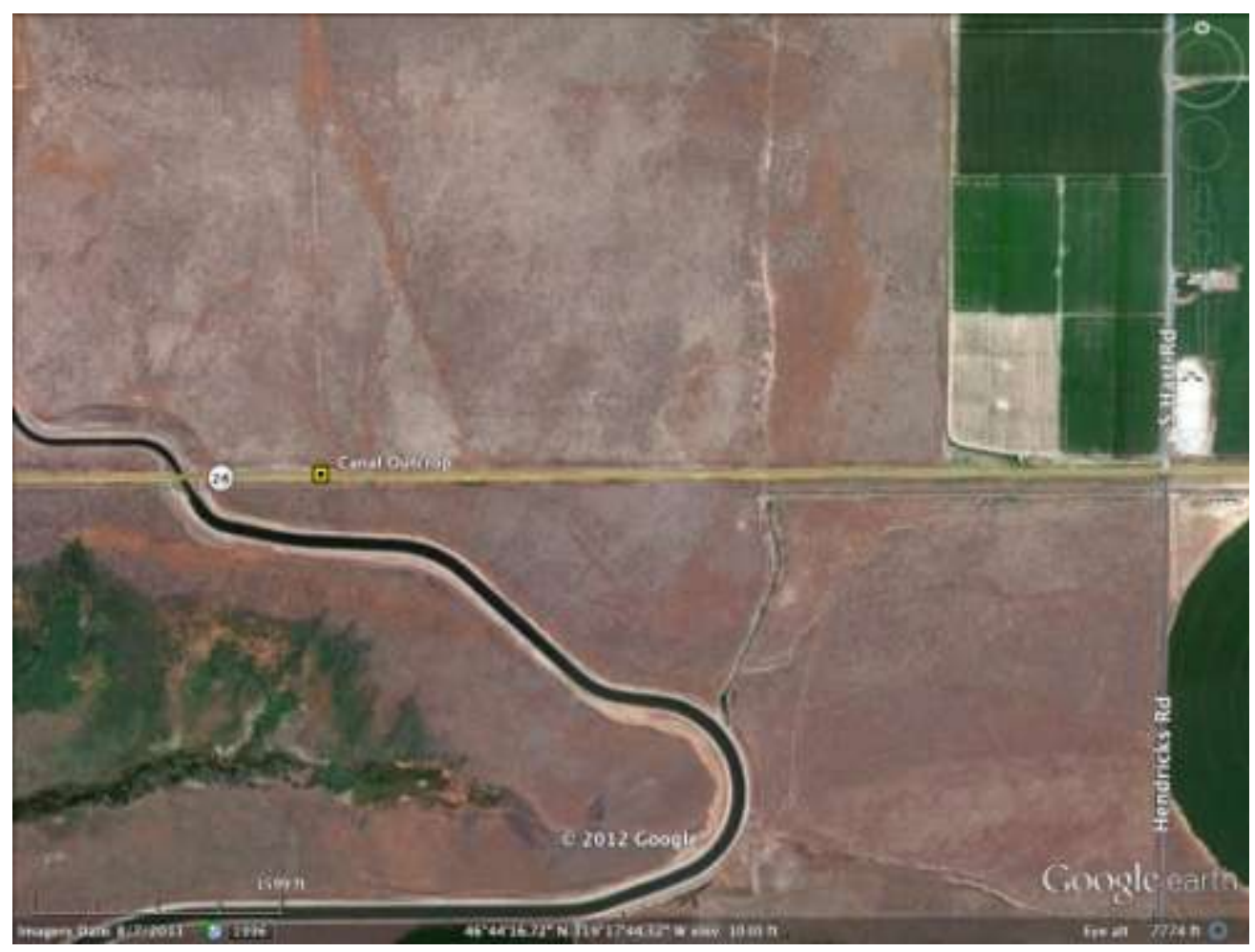

Figure 92 Location of the Canal Outcrop field site. 
The Canal Outcrop is located along SR 24 also called West Muse Road 13.5 $\mathrm{km}$ from Othello, Washington (Figure 92). The outcrop is approximately $15.4 \mathrm{~km}$ directly southwest of the Othello Canal outcrop. I discovered the outcrop with Barnard in 2010. The GPS coordinates for this site are N 46.738063 latitude and W 119.303453 longitude; the elevation is $301 \mathrm{~m}$. The outcrop has one calcrete paleosol and one slackwater flood deposit (Figure 93).

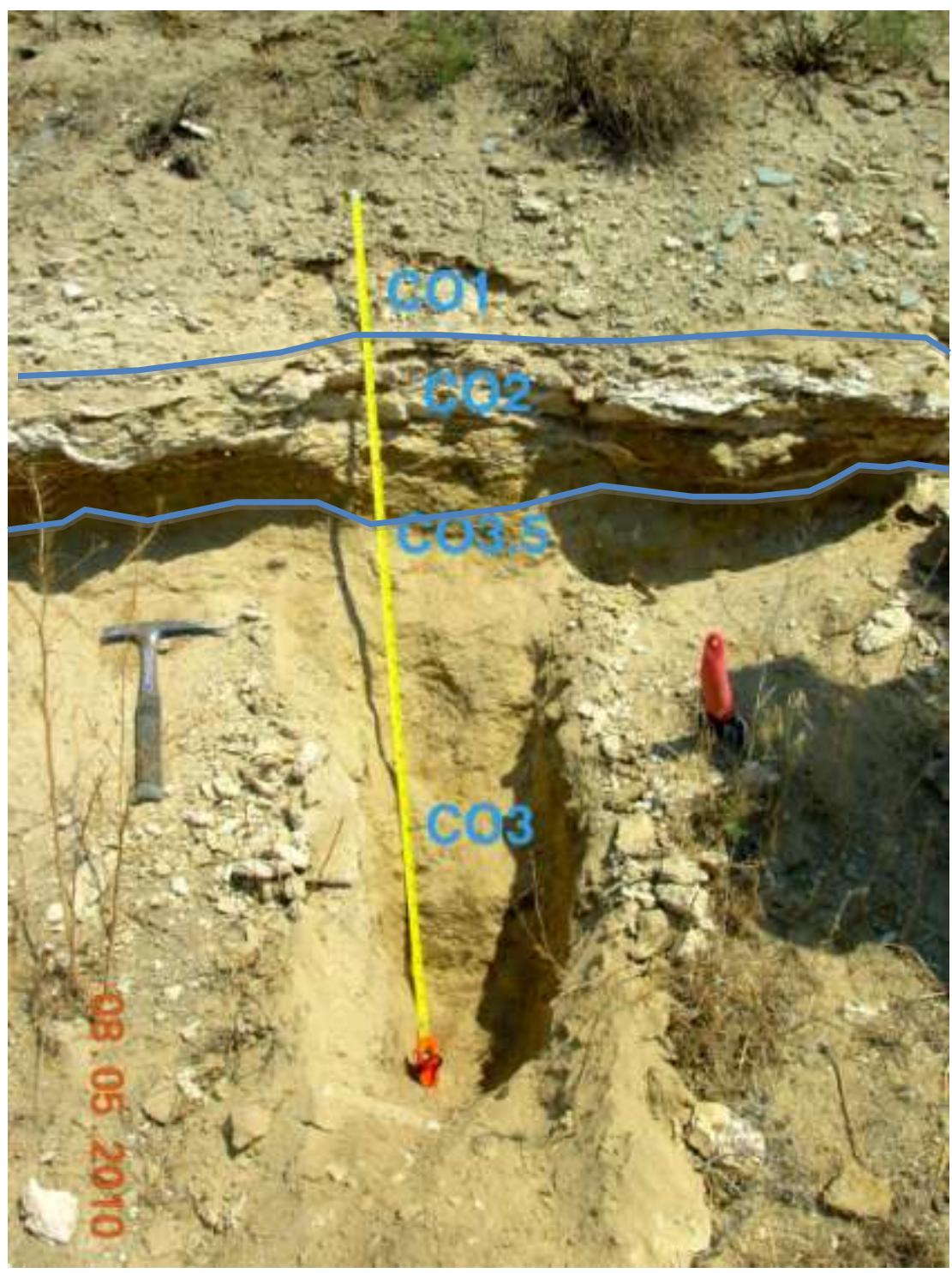

Figure 93 Canal Outcrop with sample locations labeled. Photograph by Kathryn Barnard. 


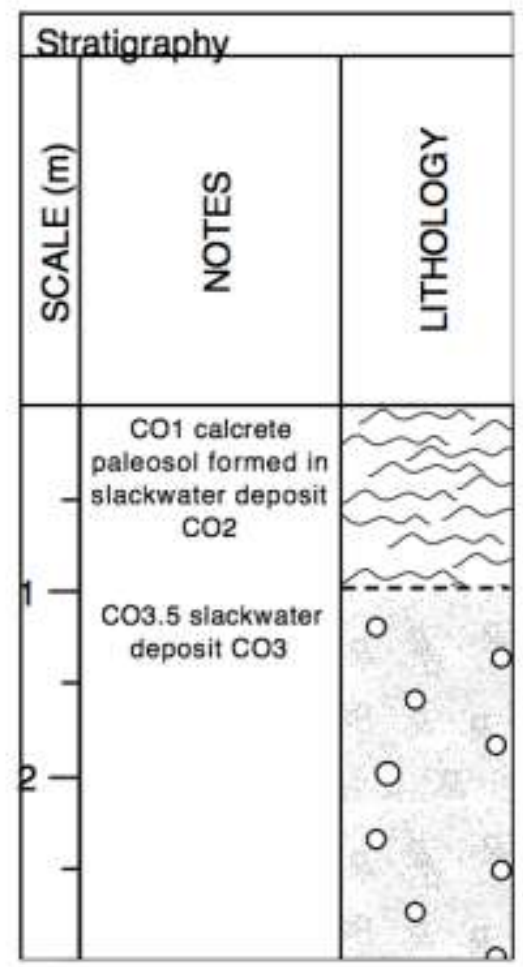

Figure 94 Stratigraphy of Canal Outcrop.

Sample CO2 was taken in the prominent calcrete paleosol layer and measures $28.5 \%$ \pm 1.3 , Stage III calcrete development (Table 24). Sample CO1 is in the upper part of the calcrete and measures $5.4 \% \pm 0.3 \mathrm{CaCO}_{3}$, Stage II.

Table 24 Chittick results for Canal Outcrop site.

\begin{tabular}{|lcc|}
\hline \multicolumn{1}{|c|}{ Sample ID } & $\begin{array}{c}\text { Average } \mathrm{CaCO}_{3} \\
\text { Percent }\end{array}$ & $\begin{array}{c}\text { Stage of } \\
\text { Development }\end{array}$ \\
\hline CO1 calcrete paleosol & $5.4 \pm 0.3$ & Stage II \\
\hline $\begin{array}{l}\text { CO2 calcrete paleosol in } \\
\text { slackwater deposit }\end{array}$ & $28.5 \pm 1.3$ & Stage III \\
\hline CO3 slackwater deposit & $0.6 \pm 0.0$ & Stage I \\
\hline CO3.5 slackwater deposit & $0.4 \pm 0.1$ & Stage I \\
\hline
\end{tabular}




\subsubsection{Othello Canal (Othello, Washington)}

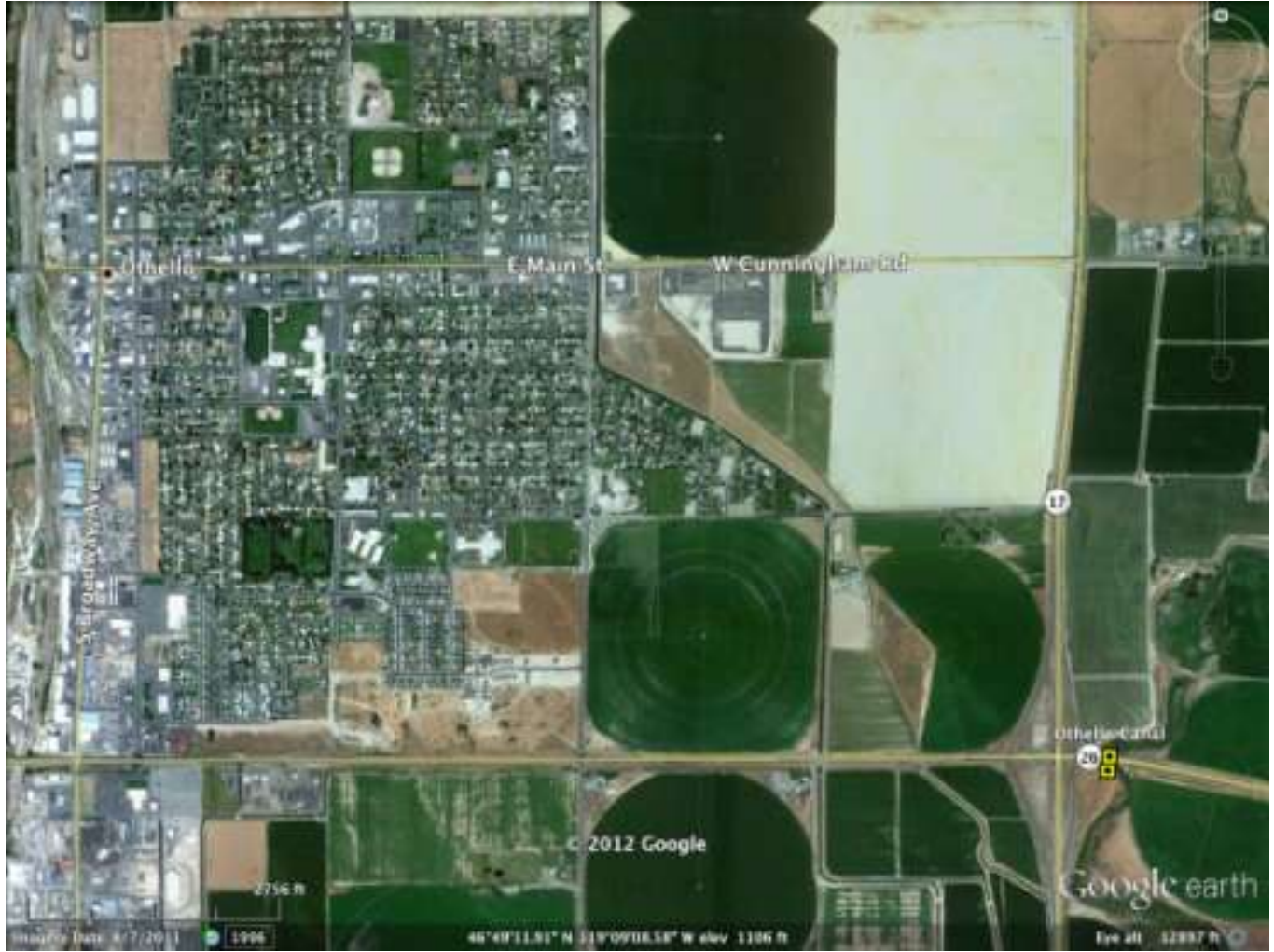

Figure 95 Location of the Othello Canal field site, southeast of Othello, Washington.

The Othello Canal outcrop is located along HW26 just 100 m east of the HW17 and HW26 intersection (Figure 95). I discovered the outcrop with Barnard in 2010. The GPS coordinates for this site are N 46.81168 latitude and W -119.131982 longitude; the elevation is $329 \mathrm{~m}$. A calcrete paleosol that is two meters thick in places overlies a slackwater deposit at the outcrop.

Sample 0C3 was collected from the massive calcrete paleosol and measures $38.3 \% \pm 4.79 \mathrm{CaCO}_{3}$, Stage III+ calcrete development (Figure 96). However, based on the massive and platy morphology and thickness of the paleosol, it qualifies for Stage V soil development. 


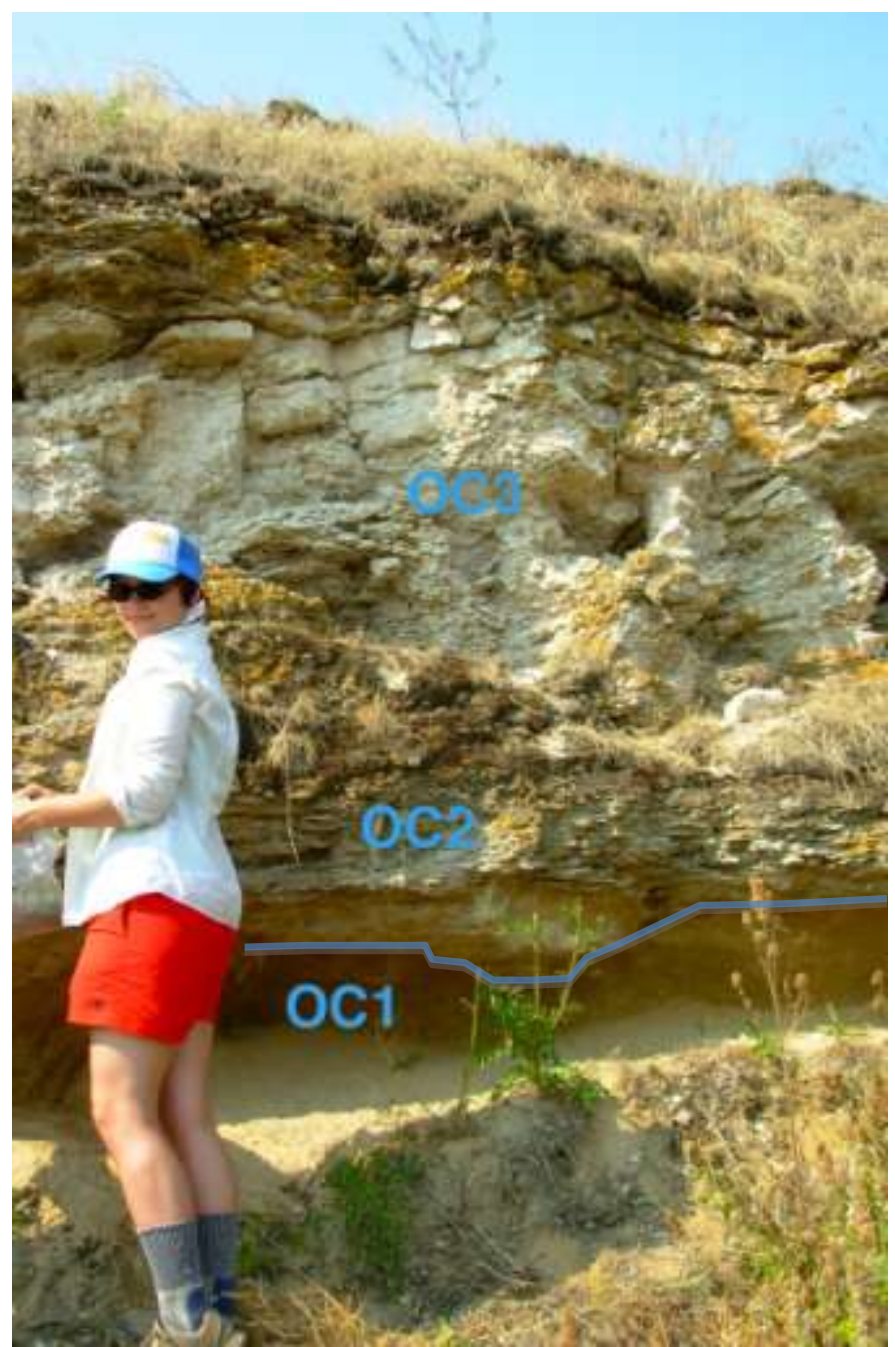

Figure 96 Othello Canal outcrop with sample locations labeled.

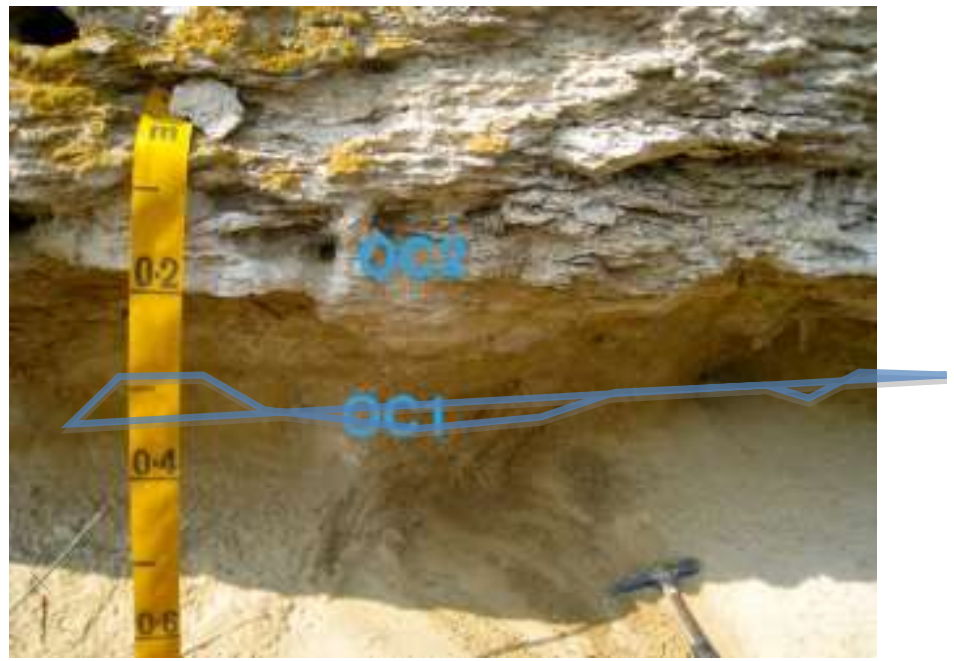

Figure 97 Othello Canal close-up with sample locations labeled. 


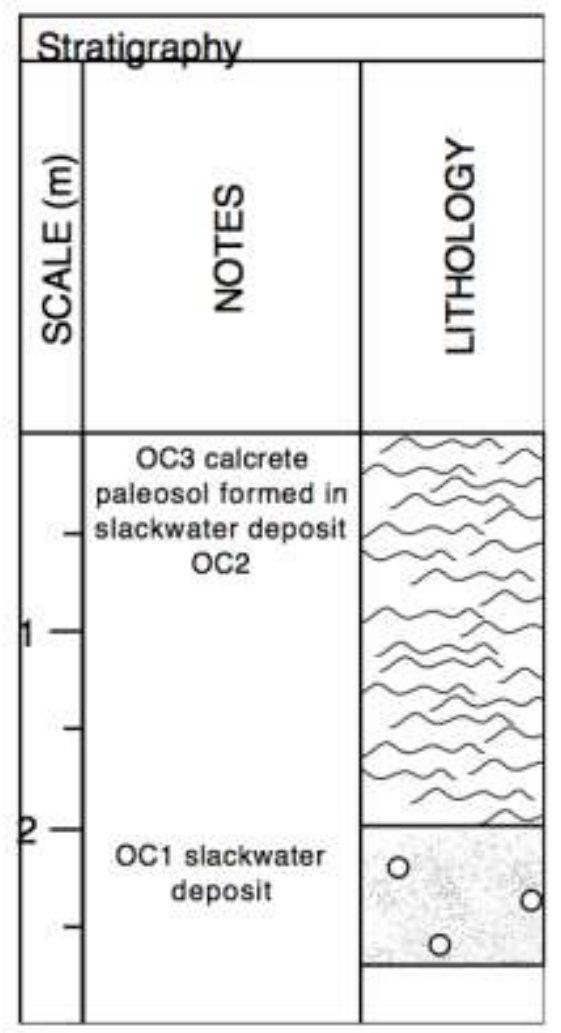

Figure 98 Stratigraphy of Othello Canal outcrop.

Sample 0C2, collected below OC3, is in the platy calcrete and measures 28.27 \pm 1.33 percent $\mathrm{CaCO}_{3}$, Stage III development (Table 25). A slackwater deposit, OC1, lies below the paleosol. OC1 was tested for particle size analysis and contains $29.1 \%$ sand, $67.5 \%$ silt, and $3.5 \%$ clay. The sand contains quartz.

The soil development in the paleosol takes hundreds of thousands of years to form. The underlying slackwater flood deposit, OC1, is probably Early Pleistocene in age and possibly of the oldest preserved Ancient Cataclysmic Flood deposits (Figure 97). The Othello Canal site correlates with the Canal Outcrop site, which is $15.4 \mathrm{~km}$ southwest and has the same stratigraphy. Based on morphology, this is a Stage V calcrete (Machette, 1985). 
Table 25 Chittick results for Othello Canal site.

\begin{tabular}{|l|cc|}
\hline \multicolumn{1}{|c|}{ Sample ID } & $\begin{array}{c}\text { Average } \mathrm{CaCO}_{3} \\
\text { Percent }\end{array}$ & $\begin{array}{c}\text { Stage of } \\
\text { Development }\end{array}$ \\
\hline OC1 slackwater deposit & $0.8 \pm 0.5$ & Stage I \\
\hline $\begin{array}{l}\text { OC2 calcrete paleosol in } \\
\text { slackwater deposit }\end{array}$ & $28.3 \pm 1.3$ & Stage III \\
\hline $\begin{array}{l}\text { OC3 calcrete paleosol in } \\
\text { slackwater deposit }\end{array}$ & $38.3 \pm 4.8$ & Stage III+ \\
\hline
\end{tabular}

\subsubsection{Ritzville (Washtucna, Washington)}

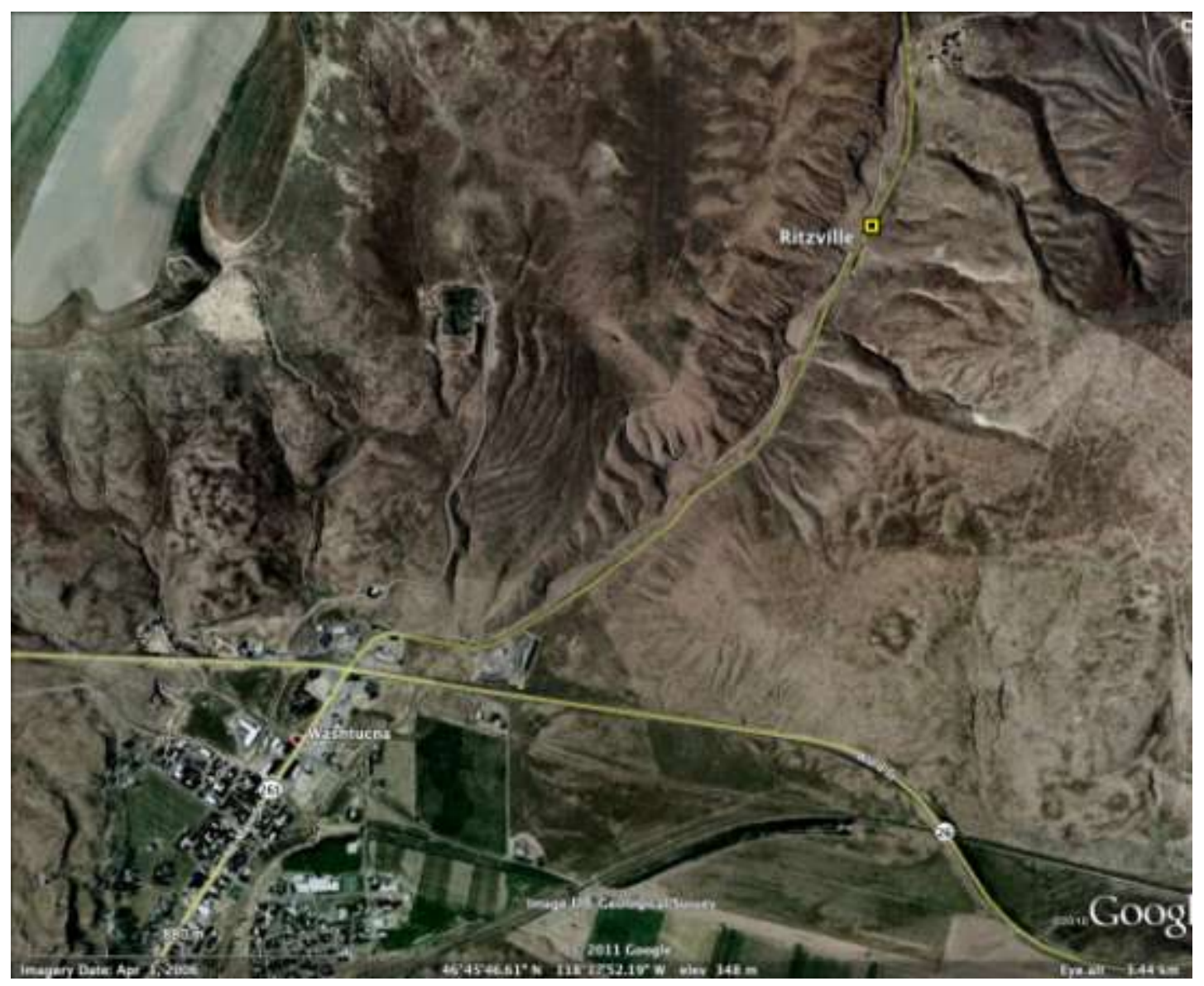

Figure 99 Location of the Ritzville field site. 


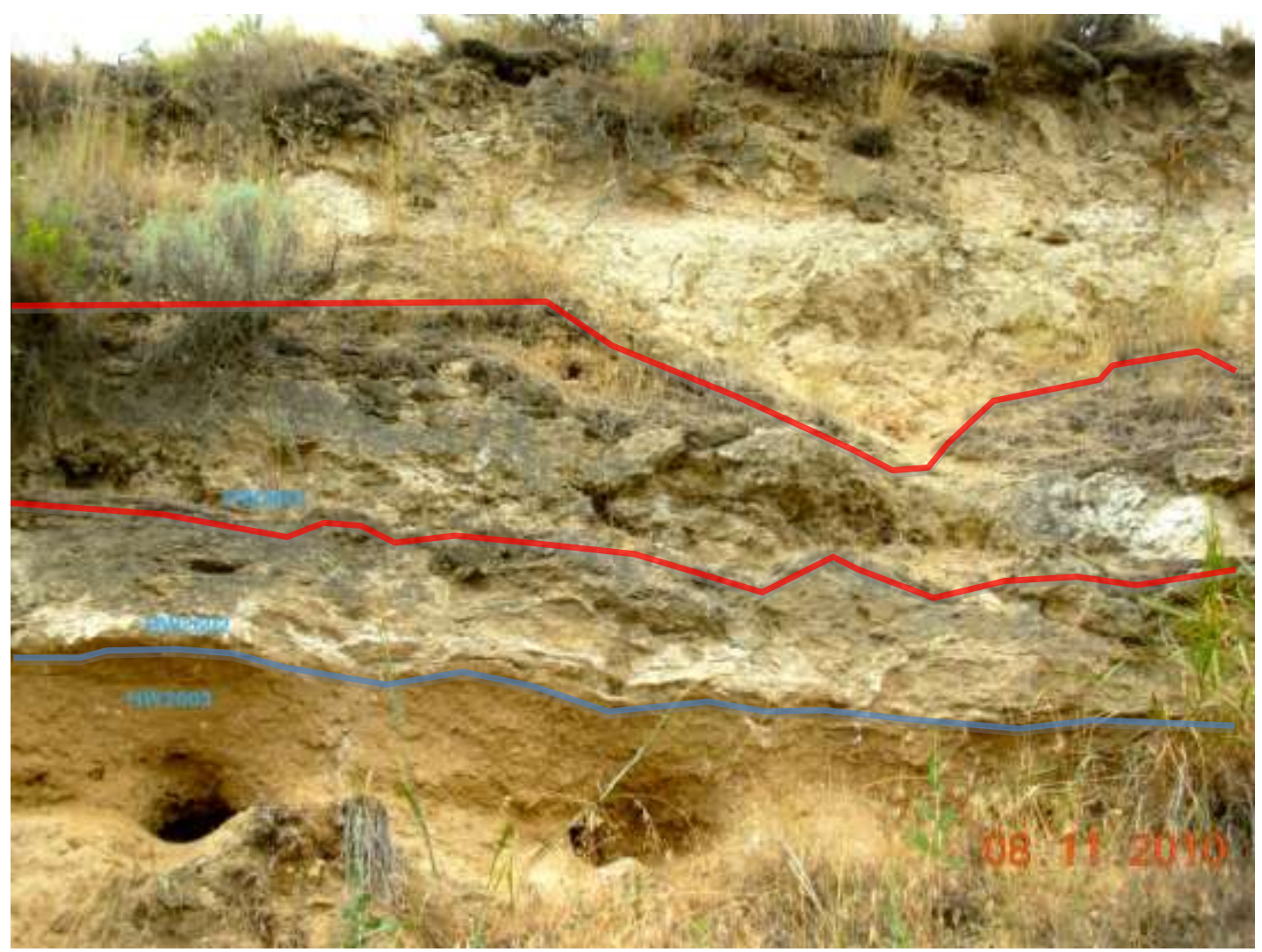

Figure 100 Ritzville field sites, described by McDonald and Busacca (1988a). Samples were not collected from this outcrop but correlate to the adjacent section that was sampled. Photograph by Kathryn Barnard.

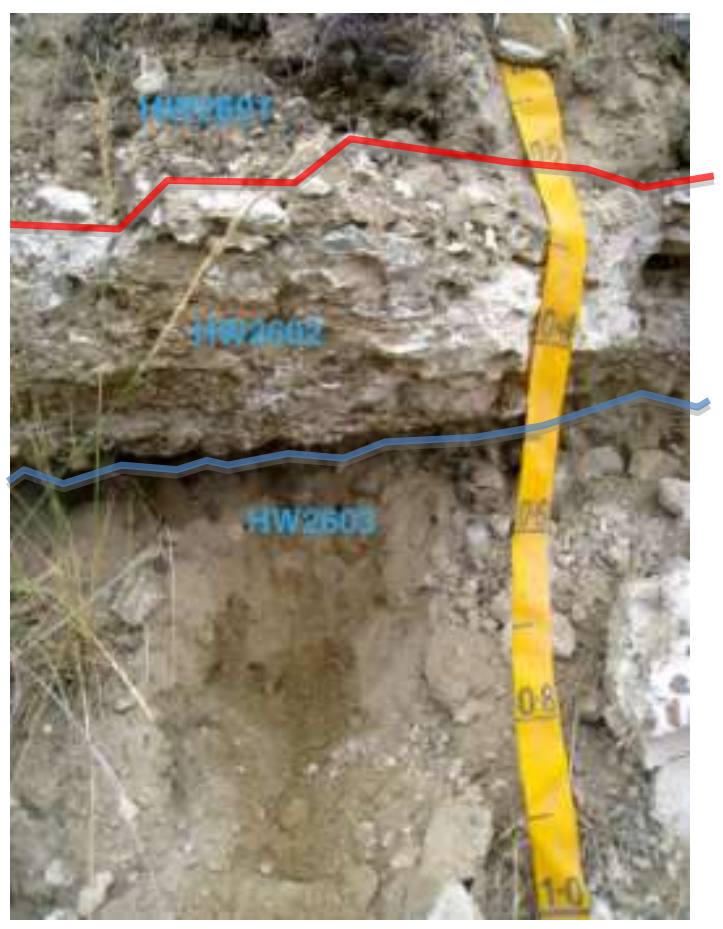


Figure 101 HW260 Field site adjacent to the Ritzville site, samples collected in marked layers.

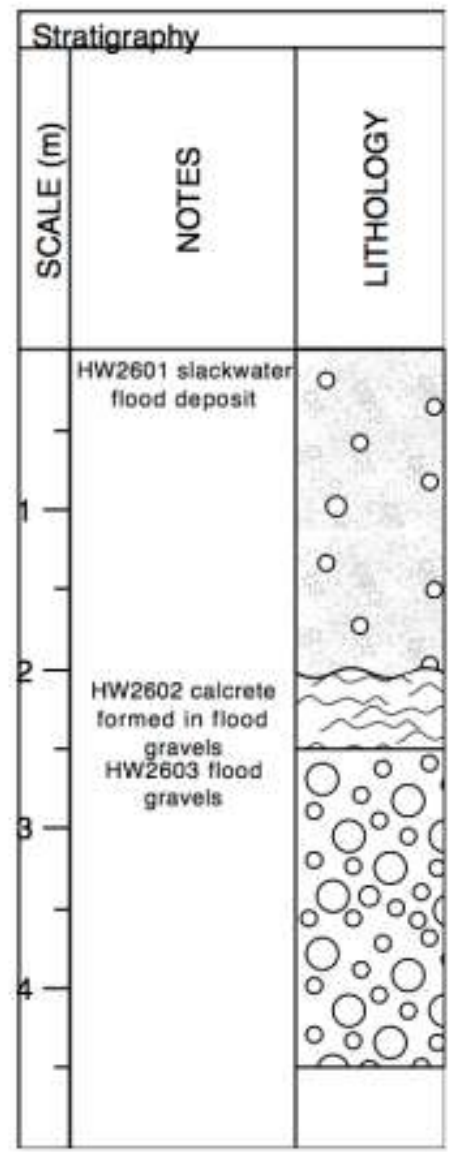

Figure 102 Stratigraphy of HW260 outcrop.

The Ritzville site is located along Highway 261, north of Washtucna (Figure 99). The GPS coordinates for this site are N 46.769984 latitude and W -118.288106 longitude; the elevation is $341 \mathrm{~m}$. The samples were collected from an outcropping paleosol (Figure 101) adjacent to the Ritzville outcrop (Figure 100) studied by McDonald and Busacca (1988a). The Ritzville outcrop has three unconformities, shown in red. One unconformity is below the lowermost sample collected, HW2603. HW2603 was taken in a flood deposit layer containing basalt gravel clasts with $10.0 \% \pm 1.2 \mathrm{CaCO}_{3}$ Stage II development, coatings on the underside of clasts, in 
a quartz sand matrix. A continuous calcrete paleosol containing basalt pebbles overlies the flood deposit, layer $\mathrm{HW} 2602$, which contains $20.4 \% \pm 1.3 \mathrm{CaCO}_{3}$, Stage III development. Layer HW2601 is a sandy deposit with scattered basalt pebbles that overlies HW2602, separated by an unconformity. At the Ritzville outcrop, an angular unconformity cuts the two paleosols. The material above the unconformity is comprised of "lenses of basaltic sand and fragments of paleosols" (McDonald and Busacca, 1988a). Above the unconformity there is also evidence of Mount St. Helen's set $\mathrm{C}$ tephra, which provides a minimum age of $36 \mathrm{Ka}$ (Mullineaux et al., 1978) for the paleosol. Based on the tephra and amount of soil development, I interpret ages of the floods here as Middle Pleistocene.

Table 26 Chittick results for Ritzville site.

\begin{tabular}{|l|cc|}
\hline \multicolumn{1}{|c|}{ Sample ID } & $\begin{array}{c}\text { Average } \mathrm{CaCO}_{3} \\
\text { Percent }\end{array}$ & $\begin{array}{c}\text { Stage of } \\
\text { Development }\end{array}$ \\
\hline $\begin{array}{l}\text { HW2601 slackwater } \\
\text { flood deposit }\end{array}$ & $3.8 \pm 0.2$ & Stage II \\
\hline $\begin{array}{l}\text { HW2602 calcrete } \\
\text { paleosol in flood gravels }\end{array}$ & $20.4 \pm 1.3$ & Stage III \\
\hline HW2603 flood gravels & $10.0 \pm 1.2$ & Stage II \\
\hline
\end{tabular}

\subsubsection{HW125 (Prescott, Washington)}

The HW125 outcrop is located at milepost 19 along HW125 (Figure 103). The GPS coordinates for this site are N 46.23445707 latitude and W -118.3727899 longitude; the elevation is $302.7 \mathrm{~m}$. The outcrop correlates to the Winans Road sites and has the same stratigraphy, a calcrete paleosol developed in loess overlying a slackwater deposit, with basalt bedrock below (Figure 104). No samples were 
collected at this site. I interpret the slackwater deposit to correlate to the floods at Winans Road, Middle Pleistocene in age.

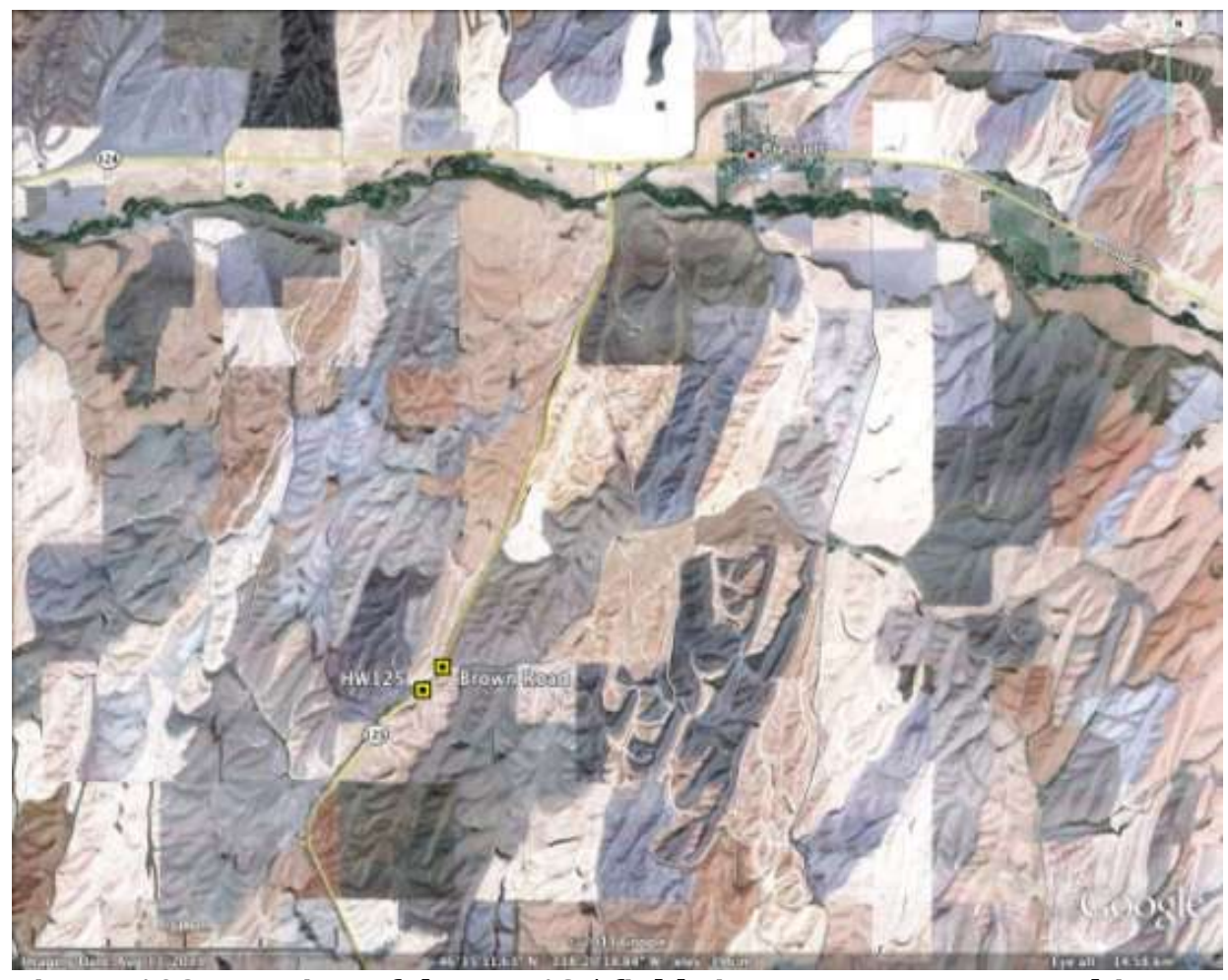

Figure 103 Location of the HW125 field site near Prescott, Washington.

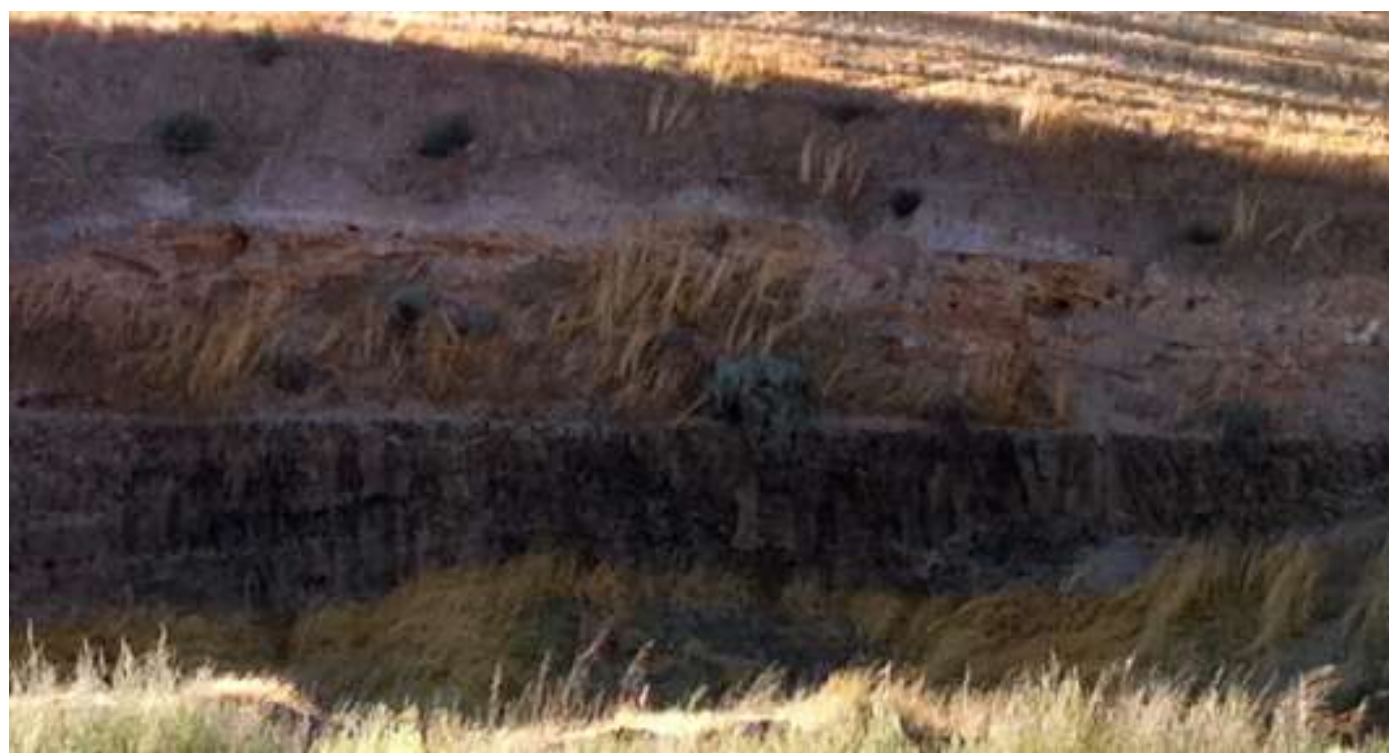

Figure 104 HW125 outcrop. 


\subsubsection{Brown Road (Prescott, Washington)}

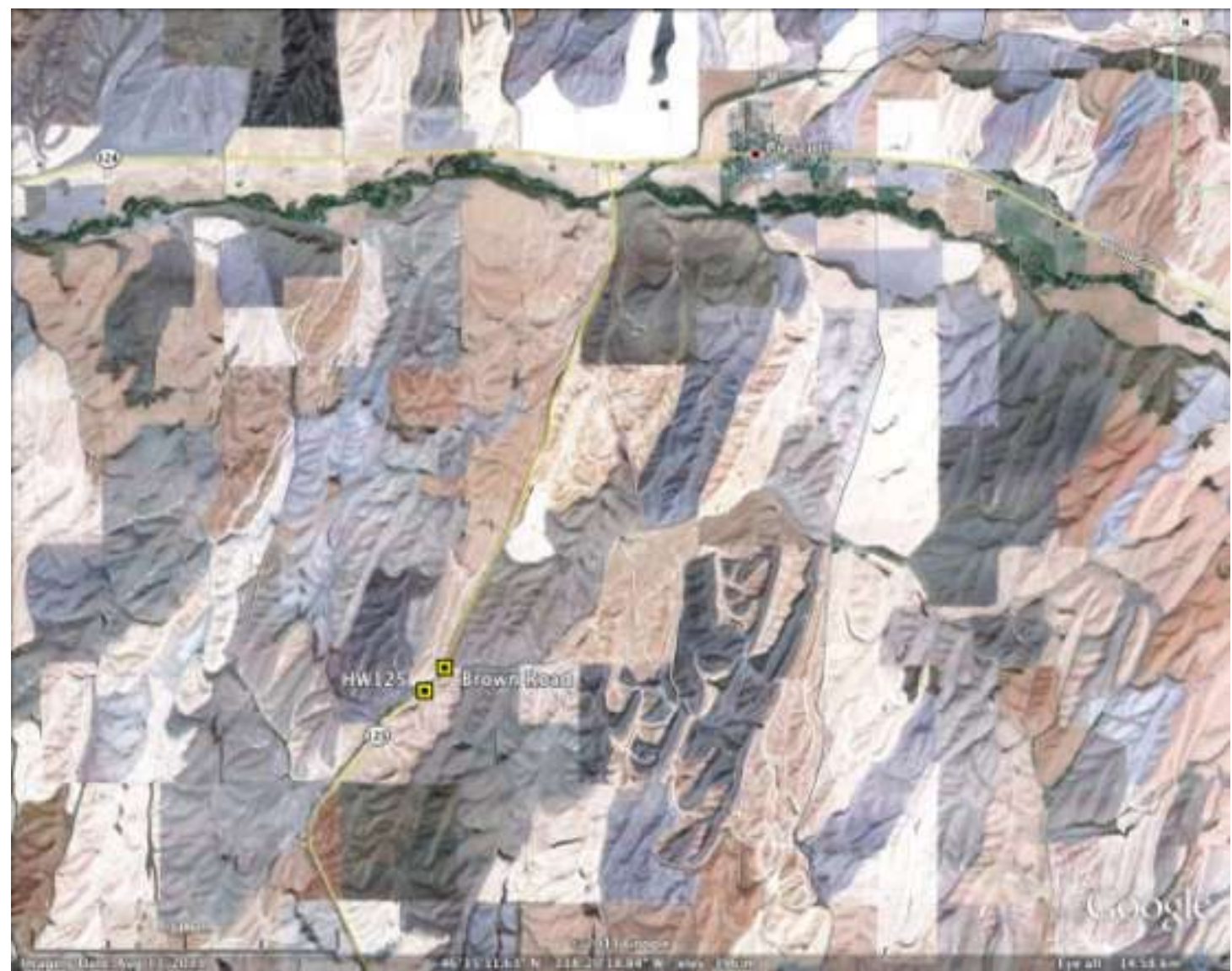

Figure 105 Location of the Brown Road field site near Prescott, Washington.

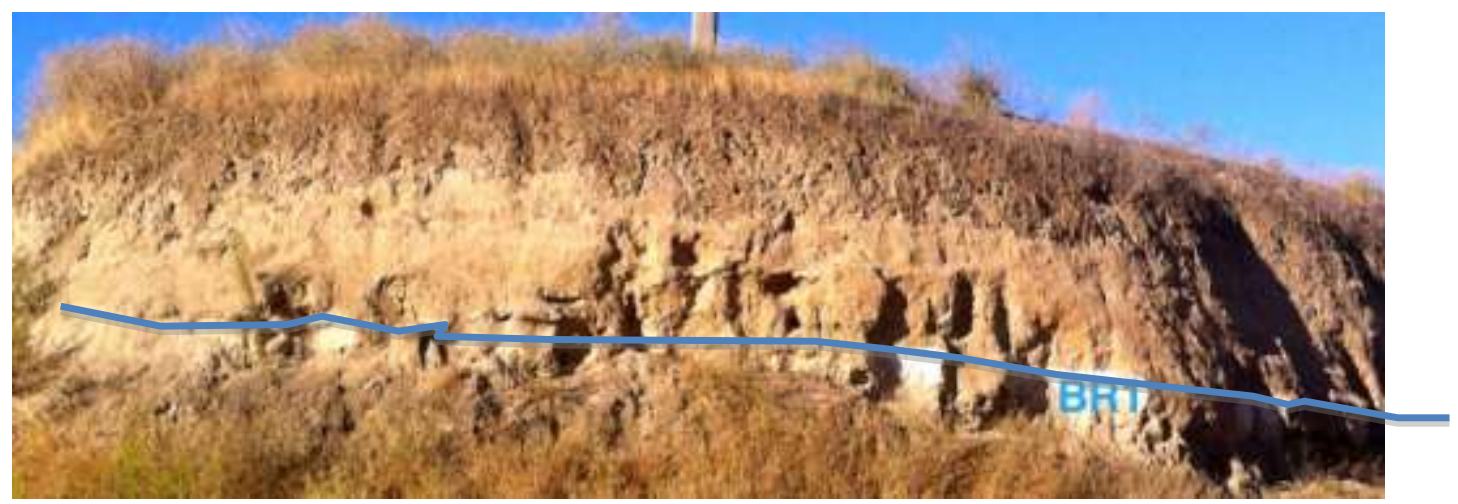

Figure 106 Brown Road outcrop with sample locations labeled. 
The Brown Road site is located 0.4 km north of the HW125 site along HW125 (Figure 105). The GPS coordinates for this site are N 46.23728007 latitude and W 118.3692935 longitude; the elevation is $311.2 \mathrm{~m}$. The site is newly discovered. The BR1 sample was taken in the lower part of the diamict in the Bk horizon, the section is mostly massive and contains a few basalt gravels (Figure 106). BR1 measured $12.4 \% \pm 0.3$ percent $\mathrm{CaCO}_{3}$, Stage II+ development (Table 27). The flood deposit is probably Middle Pleistocene.

Table 27 Chittick results for Brown Road site.

\begin{tabular}{|l|cc|}
\hline \multicolumn{1}{|c|}{ Sample ID } & $\begin{array}{c}\text { Average } \mathrm{CaCO}_{3} \\
\text { Percent }\end{array}$ & $\begin{array}{c}\text { Stage of } \\
\text { Development }\end{array}$ \\
\hline $\begin{array}{l}\text { BR1 calcrete paleosol } \\
\text { in slackwater deposit }\end{array}$ & $12.4 \pm 0.3$ & Stage II+ \\
\hline
\end{tabular}

\subsubsection{The Dalles (The Dalles, Oregon)}

Cordero (1997) studied a roadcut on Oregon Highway 197, three kilometers southeast of The Dalles (Figure 107). The GPS coordinates for this site are N 45.57851944 latitude and $\mathrm{W}-121.1049139$ longitude; the elevation is $284 \mathrm{~m}$. The site contains five paleosols, with carbonate formation, scattered gravel of "varied lithologies, including granite" is present throughout the section (Cordero, 1997). Missoula Flood slackwater deposits and loess overlie the older calcrete capped flood deposits at the north end of the section. Cordero (1997) suggests that the carbonate development ranges from Stage II to IV (Table 28). Of the samples I collected, only OR3 contained Stage III calcrete development in the Chittick analysis (Table 28). 


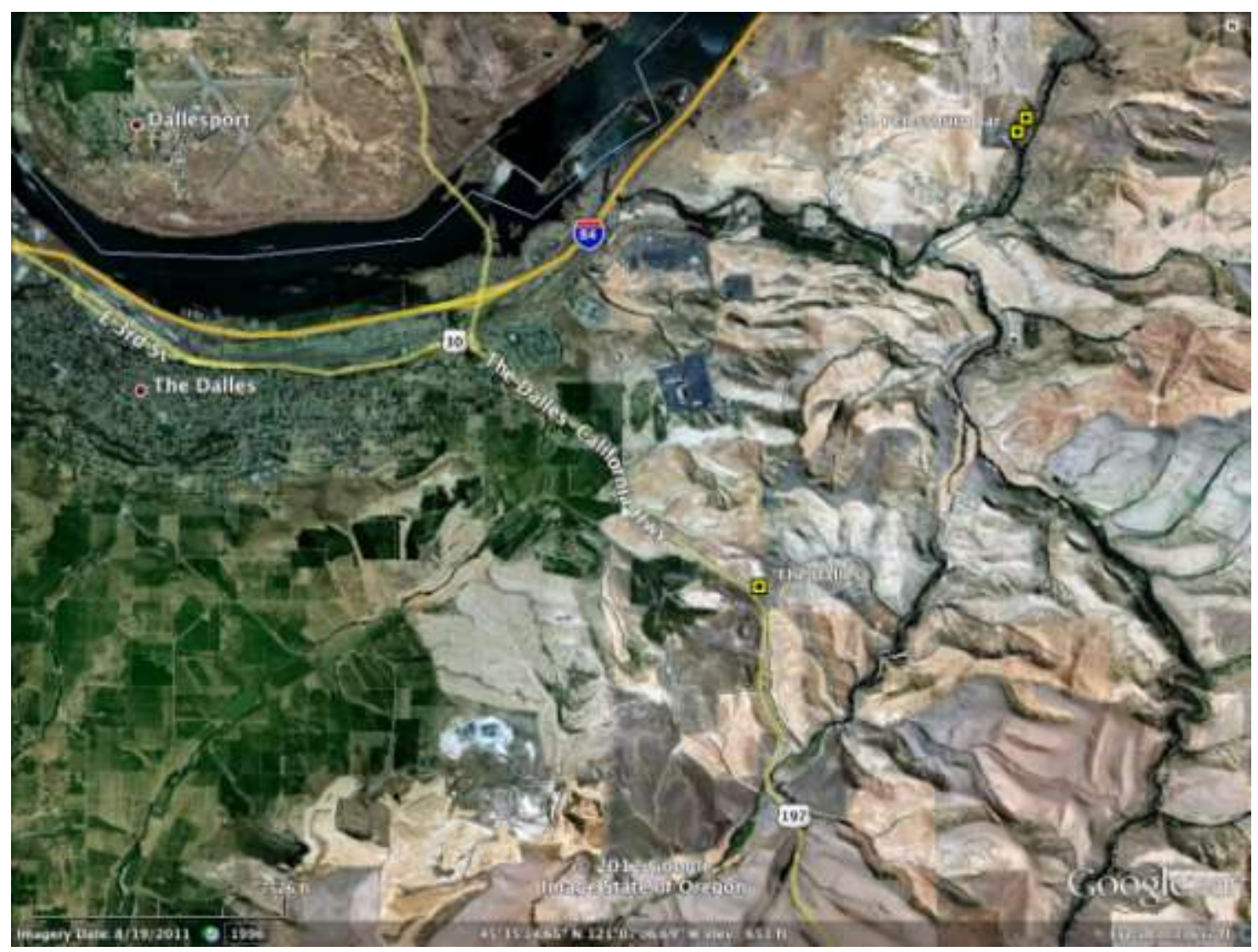

Figure 107 Location of The Dalles field site near The Dalles, Oregon.

Cordero (1997) sampled every soil horizon of each of the five paleosols; the given percentages are for the $B_{K}$ soil horizon in each paleosol (Paleosol 1-5 in Table 28). I collected and measured samples just below each paleosol in every layer (OR1-5 in Table 28). The pumice, located in OR3, has been correlated to the Dibekulewe tuff of Nevada, 600 ka (Cordero, 1997). The deposits overlie volcaniclastic sediments of The Dalles Formation (Cordero, 1997). Paleosols 4 and 5 (layer OR4.5 and 5) could have reversed magnetic polarity and needs to be measured. 


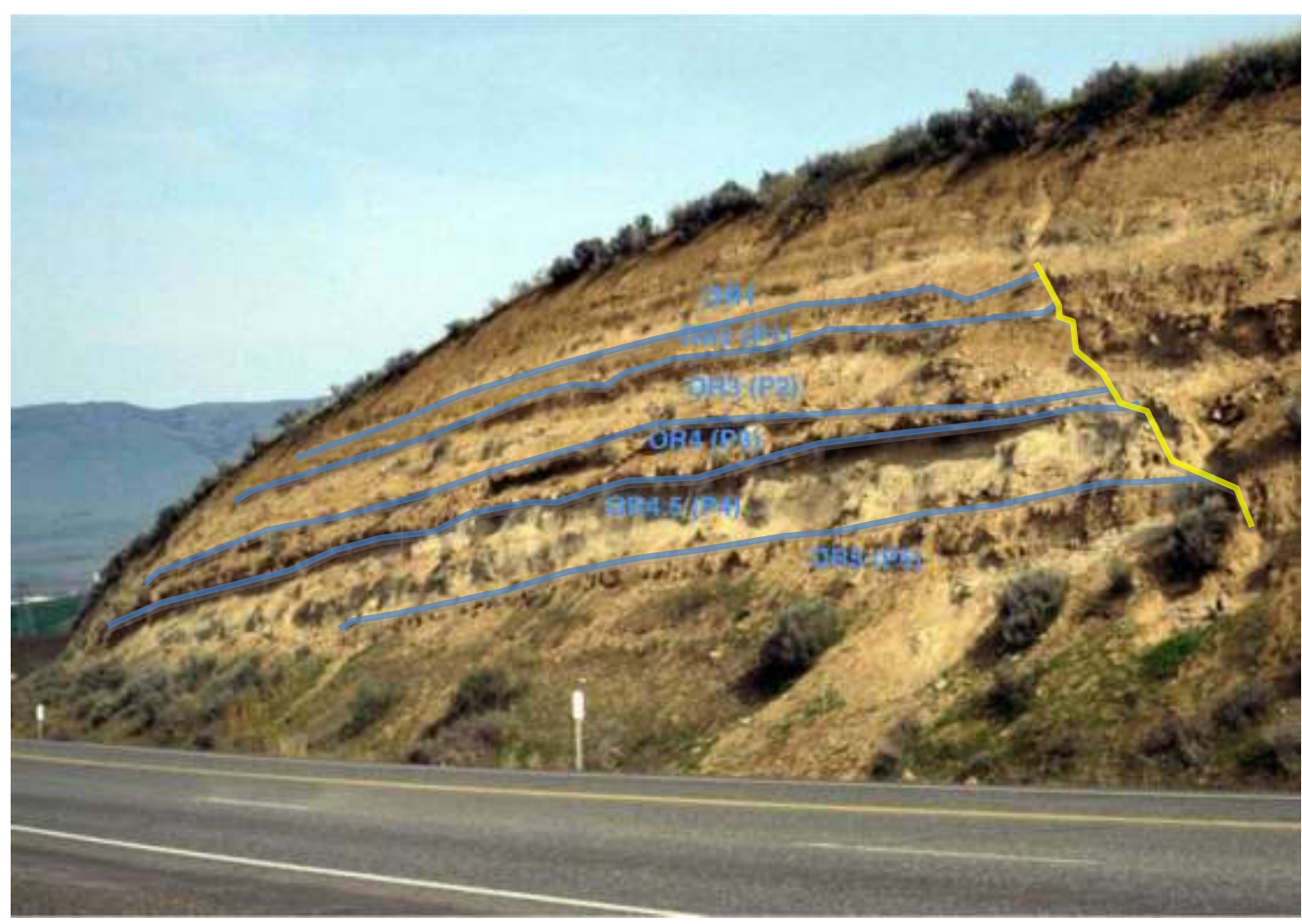

Figure 108 The Dalles outcrop with sample locations labeled; samples P1-P5 correlate to Cordero (1997). Yellow line is a reverse fault.

$={ }_{\text {OR2 PALEOSOL 1 }}$

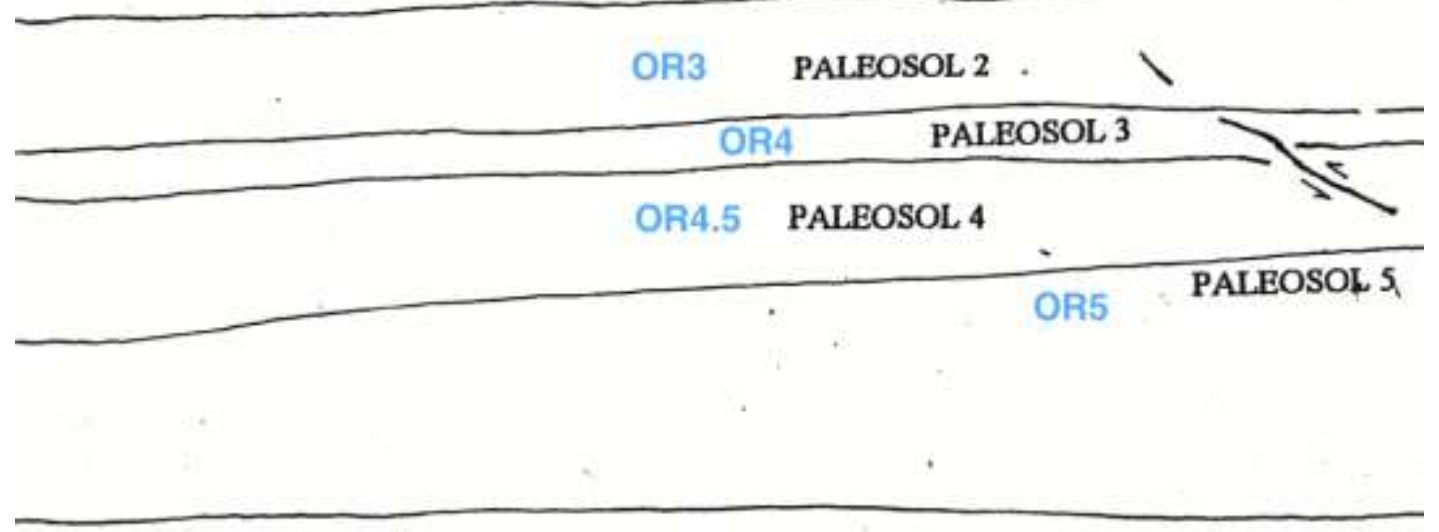

HIGHWAY 197

Figure 109 Schematic of The Dalles field site with sample locations labeled (Cordero, 1997). 
Table 28 Chittick results for The Dalles site, samples OR1-0R5 were sampled and analyzed by me; Loess-Paleosol 5 were sampled and analyzed by Cordero (1997).

\begin{tabular}{|lcc|}
\hline \multicolumn{1}{|c|}{ Sample ID } & $\begin{array}{c}\text { Average } \mathrm{CaCO}_{3} \\
\text { Percent }\end{array}$ & $\begin{array}{c}\text { Stage of } \\
\text { Development }\end{array}$ \\
\hline OR1 slackwater deposit & $0.9 \pm 0.2$ & Stage I \\
\hline OR2 slackwater deposit & $1.4 \pm 0.1$ & Stage I \\
\hline $\begin{array}{l}\text { OR3 calcrete paleosol in } \\
\text { slackwater deposit }\end{array}$ & $17.9 \pm 2.0$ & Stage III \\
\hline OR4 slackwater deposit & $1.2 \pm 0.1$ & Stage I \\
\hline OR4.5 slackwater deposit & $0.3 \pm 0.3$ & Stage I \\
\hline OR5 slackwater deposit & $1.8 \pm 0.5$ & Stage I \\
\hline Loess & 0.2 & Stage I \\
\hline $\begin{array}{l}\text { Paleosol 1 (calcrete in } \\
\text { slackwater deposit) }\end{array}$ & 27.3 & Stage III \\
\hline $\begin{array}{l}\text { Paleosol 2 (calcrete in } \\
\text { slackwater deposit) }\end{array}$ & 30.6 & Stage III \\
\hline $\begin{array}{l}\text { Paleosol 3 (calcrete in } \\
\text { slackwater deposit) }\end{array}$ & 10.9 & Stage II \\
\hline $\begin{array}{l}\text { Paleosol 4 (calcrete in } \\
\text { slackwater deposit) }\end{array}$ & 23.4 & Stage III \\
\hline $\begin{array}{l}\text { Paleosol 5 (calcrete in } \\
\text { slackwater deposit) }\end{array}$ & 46.5 & Stage III+ \\
\hline
\end{tabular}

Three paleosols lie below Paleosol 2 with the following amounts of calcrete:

Paleosol 3 has 10.9\% (Stage II), Paleosol 4 has 23.4 (Stage III), and Paleosol 5 has 46.5 (Stage III+) (Cordero, 1997). Paleosol 1 overlies Paleosol 2 and contains 27.3\% $\mathrm{CaCO}_{3}$, Stage III. I interpret two Early Pleistocene and three Early-Middle

Pleistocene floods here.

\subsection{Subsurface Sites}

\subsubsection{Cold Creek Bar (Desert Aire, Washington)}

Cold Creek bar has been previously studied by Reidel et al. (1998) and Bjornstad (2001, 2006). The giant flood bar is located along SR 24 near Vernita Rest Area and 
the intersection of SR 240, north of the Hanford site (Figure 110). The GPS coordinates for this site are $\mathrm{N} 46.6112$ latitude and $\mathrm{W}-119.7647139$ longitude; the elevation is $313.9 \mathrm{~m}$. The bar is located on the Hanford Site and is mostly inaccessible, but the subsurface stratigraphy has been analyzed with hundreds of boreholes. "Because of the expansion of the floodwaters here and their slower speed, they couldn't carry as much sediment, which resulted in deposition" (Bjornstad, 2006). This depositional area grew to 90 meters in thickness and $19 \mathrm{~km}$ long. The lower half of the flood bar sediments have reversed magnetic polarity (Bjornstad, 2006). The site has at least one Early Pleistocene flood deposit.

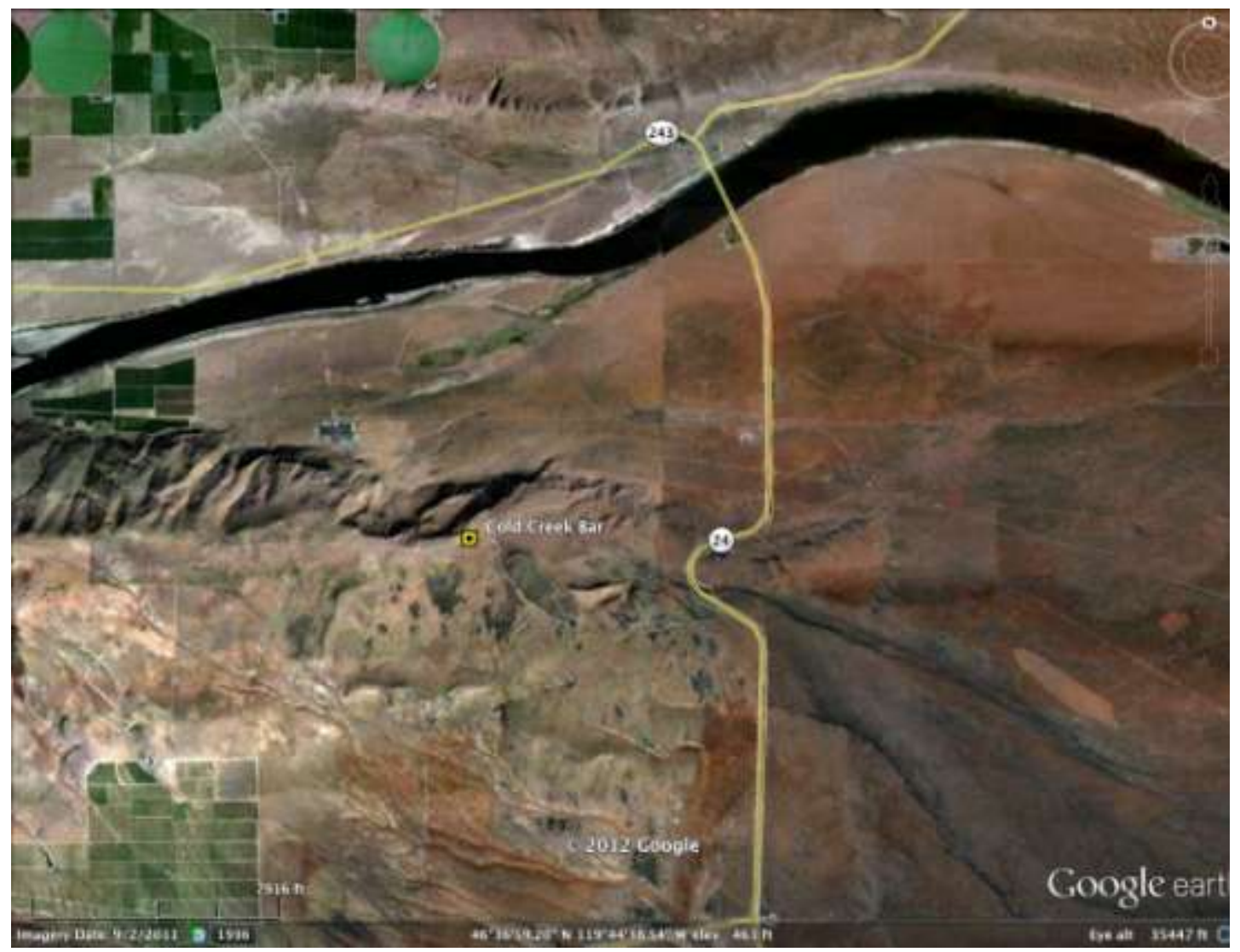

Figure 110 Location of the Cold Creek Bar field site. 


\section{Chapter 5: Discussion}

A total of 29 field sites are studied in this thesis. Four of the sites are Missoula Flood gravel pits, studied for a basis of comparison of "Missoula Flood" deposits to "Ancient Cataclysmic" flood deposits. I discovered 11 possible Ancient Cataclysmic Flood field sites. I visited most of the field sites that were analyzed by other workers including: Baker and Nummedal (1978), Patton and Baker (1978), Busacca et al.(1989), Baker et al. (1991), Kiver et al. (1991), Fecht et al. (1999), Bjornstad et al. (2001), Spencer and Jaffee (2002), Bjornstad (2006), Cordero (1997), and Gastineau (2011).

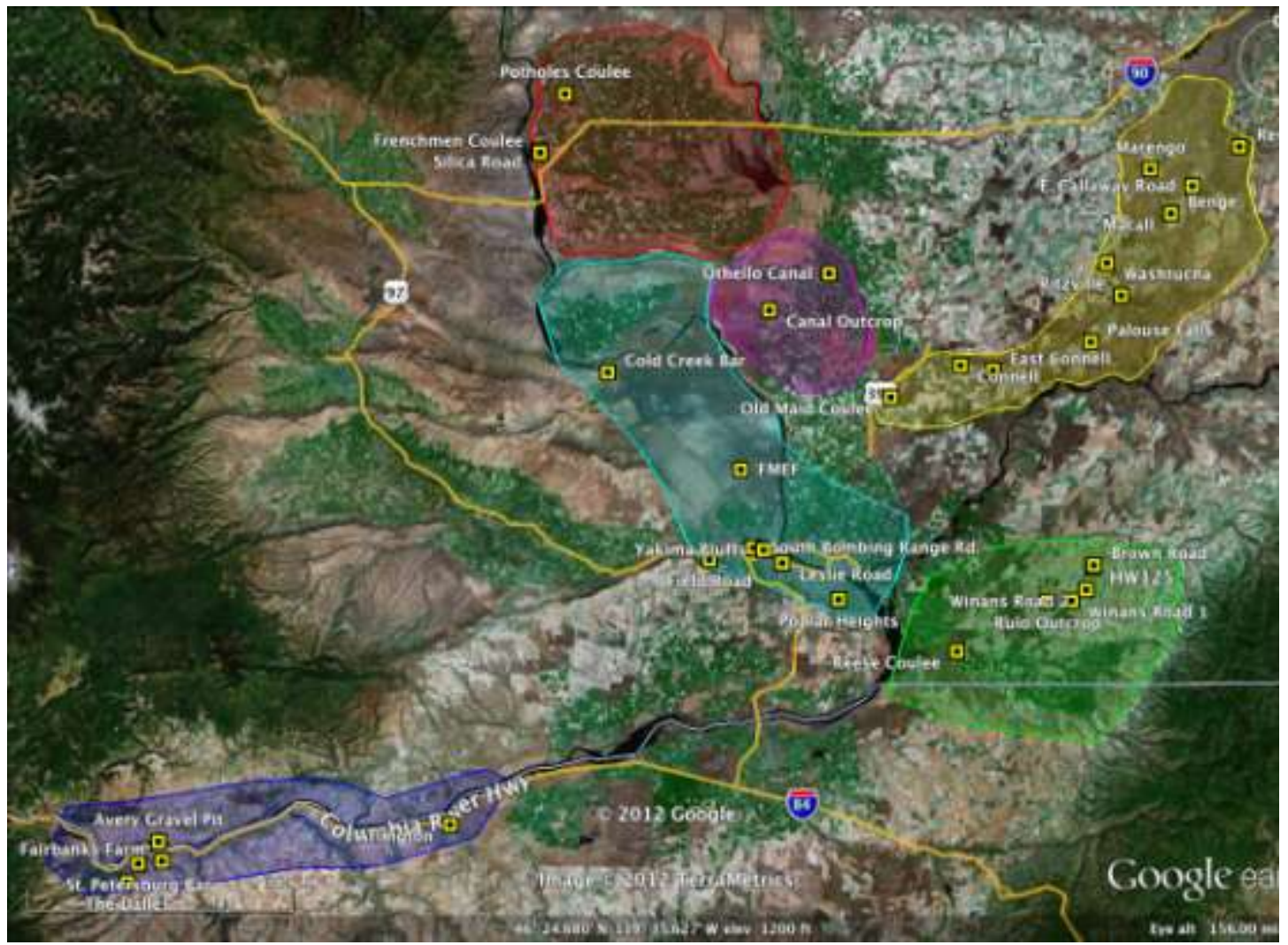

Figure 111 Overview of field sites with geographical zones colored: Columbia River Gorge (blue), Pasco Basin (teal), Walla Walla Valley (green), Othello Channels (fuchsia), Quincy Basin (red), and Cheney-Palouse (yellow). 
The sites have been broken up into six geographical areas for further analysis:

Columbia River Gorge (blue), Pasco Basin (teal), Walla Walla Valley (green), Othello Channels (fuchsia), Quincy Basin (red), and Cheney-Palouse (yellow) (Figure 111).

\subsection{Columbia River Gorge}

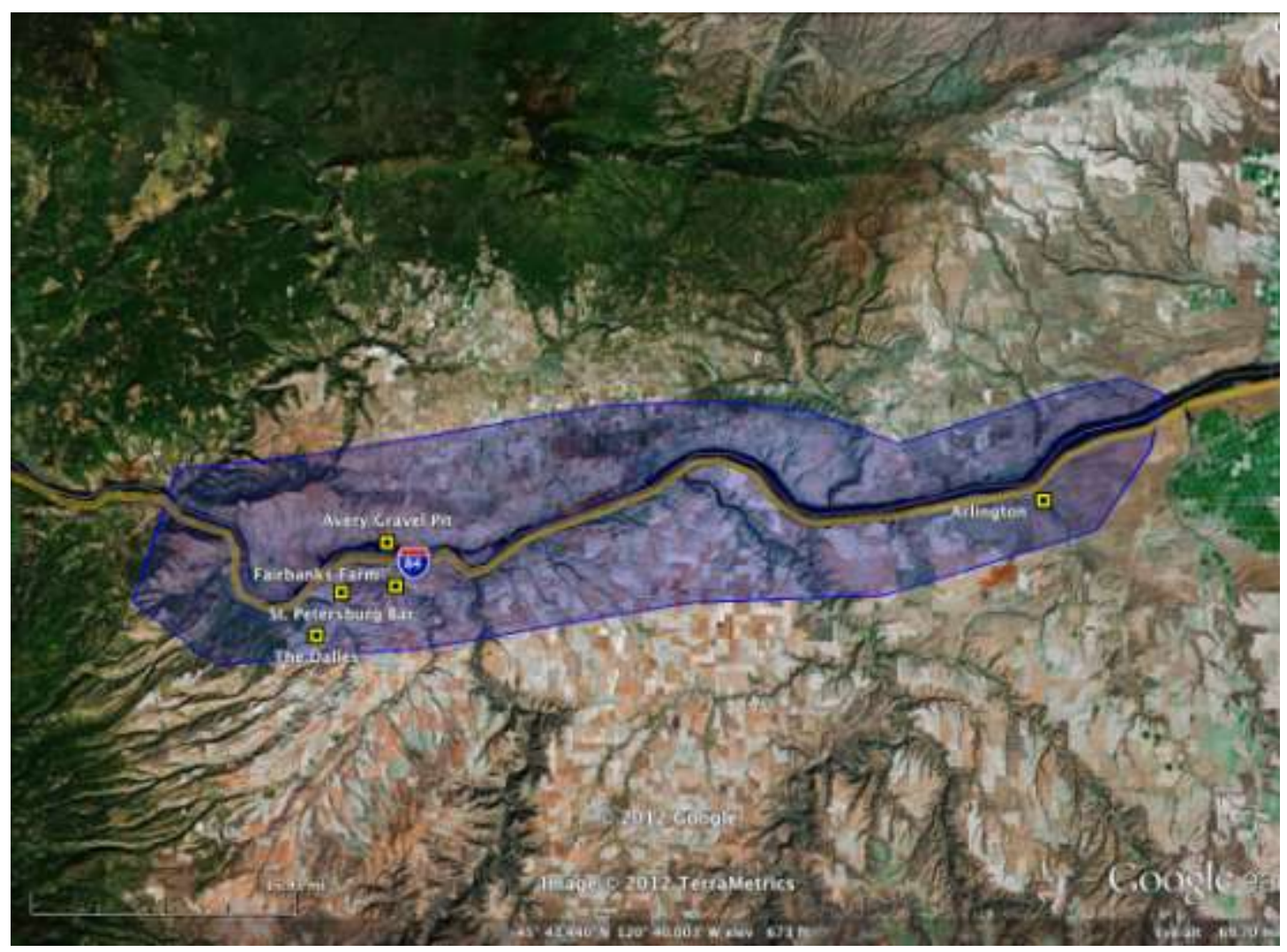

Figure 112 The Columbia River Gorge region with field sites labeled.

The Columbia River Gorge region contains the following field sites that are Missoula Flood gravel pits: St. Petersburg Bar, Avery Gravel Pit, Fairbanks Farm, and Arlington (Figure 112). The Missoula Flood sediments were sampled in order to examine the amount of calcrete soil development is present in deposits of known ages. The elevation of the sites range from 80 to 284 meters. The flood gravel samples all contained Stage I calcrete development. Many of the Ancient Cataclysmic 
Flood deposits also contain Stage I or II calcrete development because most of the $\mathrm{CaCO}_{3}$ is leached into the " $\mathrm{B}$ " soil horizon. It is taking 15,000 calendar years to develop Stage I calcrete deposits.

The Dalles field site is also in the Columbia River Gorge region. The site has five paleosols and Missoula Flood deposits at the north end. One of the paleosols contains Stage III $\mathrm{CaCO}_{3}$ development and pumice clasts dated to 600,000 years before present (Cordero, 1997). Three paleosols with calcrete development ranging from Stage II to III+ lie below the dated paleosol. One paleosol with Stage III $\mathrm{CaCO}_{3}$ overlies the dated paleosol. At least two of the floods are interpreted as Early Pleistocene and three Early-Middle Pleistocene.

\subsection{Pasco Basin}

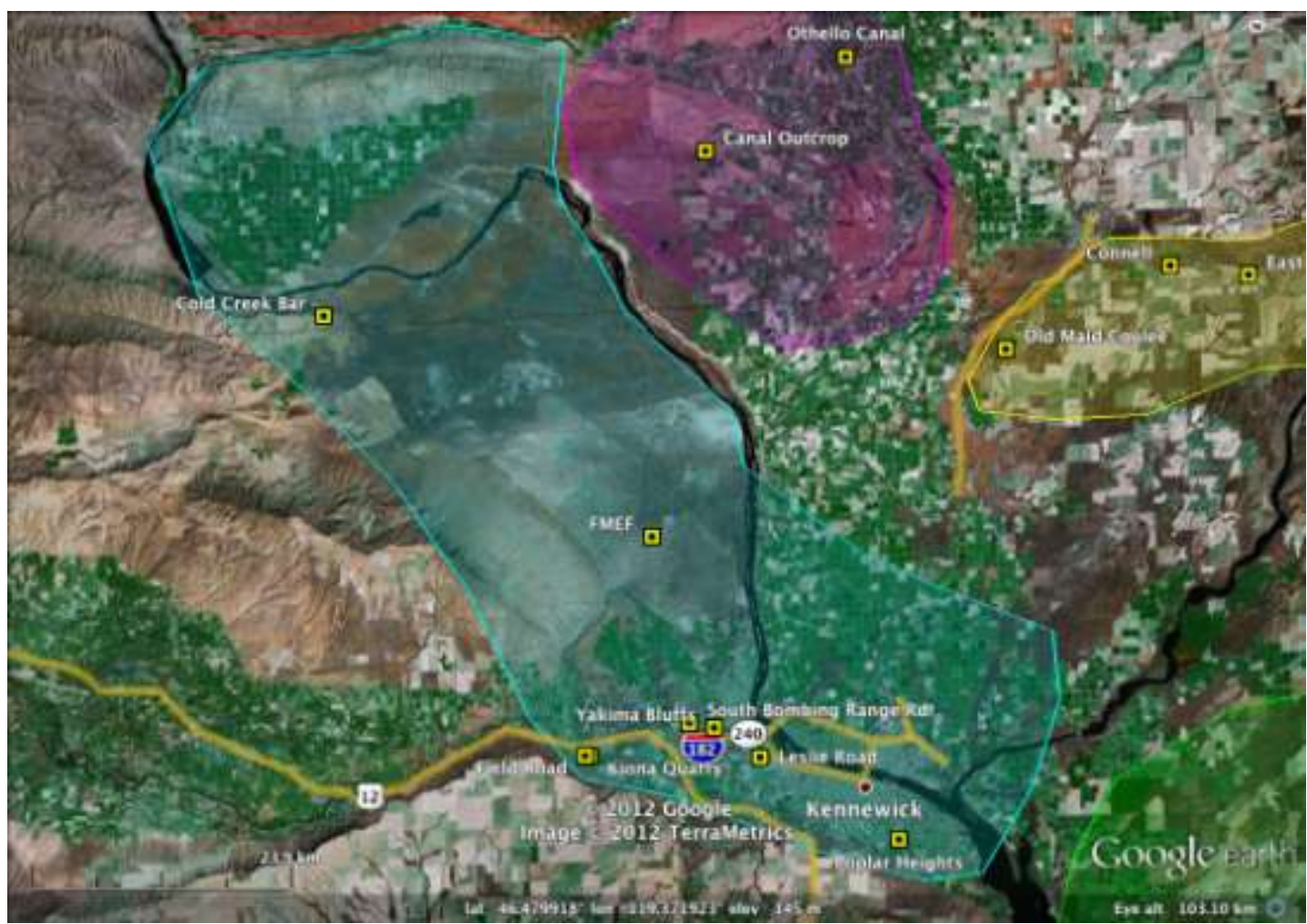

Figure 113 The Pasco Basin region with field sites labeled. 
The Pasco Basin region was a major erosional and depositional area for the Missoula Floods. Evidence for Ancient Cataclysmic Floods exists at several localities(Figure 113). The field sites (Poplar Heights, Leslie Road, Yakima Bluffs, and Field Road) range in elevation between 118 and 313.9 meters. Evidence of highenergy flood gravels and low energy slackwater rhythmites is preserved at Yakima Bluffs. High energy floods coming through this area eventually jammed the coulee and caused the Yakima River to be diverted north (Bjornstad, 2006). At least 12 Early-Middle Pleistocene floods are recorded in rhythmites with reversed magnetic polarity measured at the base of the sequence at Yakima Bluffs. There are also two Middle Pleistocene gravelly flood deposits that overlie the rhythmite sequence at Yakima Bluffs. Field Road contains one Middle Pleistocene flood deposit with Stage III calcrete development. Just next to Field Road is Kiona Quarry, which has two thick sequences of normal magnetic polarity gravels from Middle Pleistocene (Baker et al., 1991). Leslie Road has evidence for one Early Pleistocene and one Middle/Late Pleistocene flood. The Poplar Heights site has evidence for one Early Pleistocene flood. Cold Creek Bar, in the northern region of Pasco Basin, has reversed magnetic polarity sediments and at least one Early Pleistocene flood deposit. The FMEF site was not sampled, but contains flood deposits that Baker et al. (1991) interpret as one Early Pleistocene and one Middle Pleistocene. South Bombing Range Road, although no longer exists, was documented by Bjornstad et al. (2001) as having one Middle Pleistocene flood. 


\subsection{Walla Walla Valley}

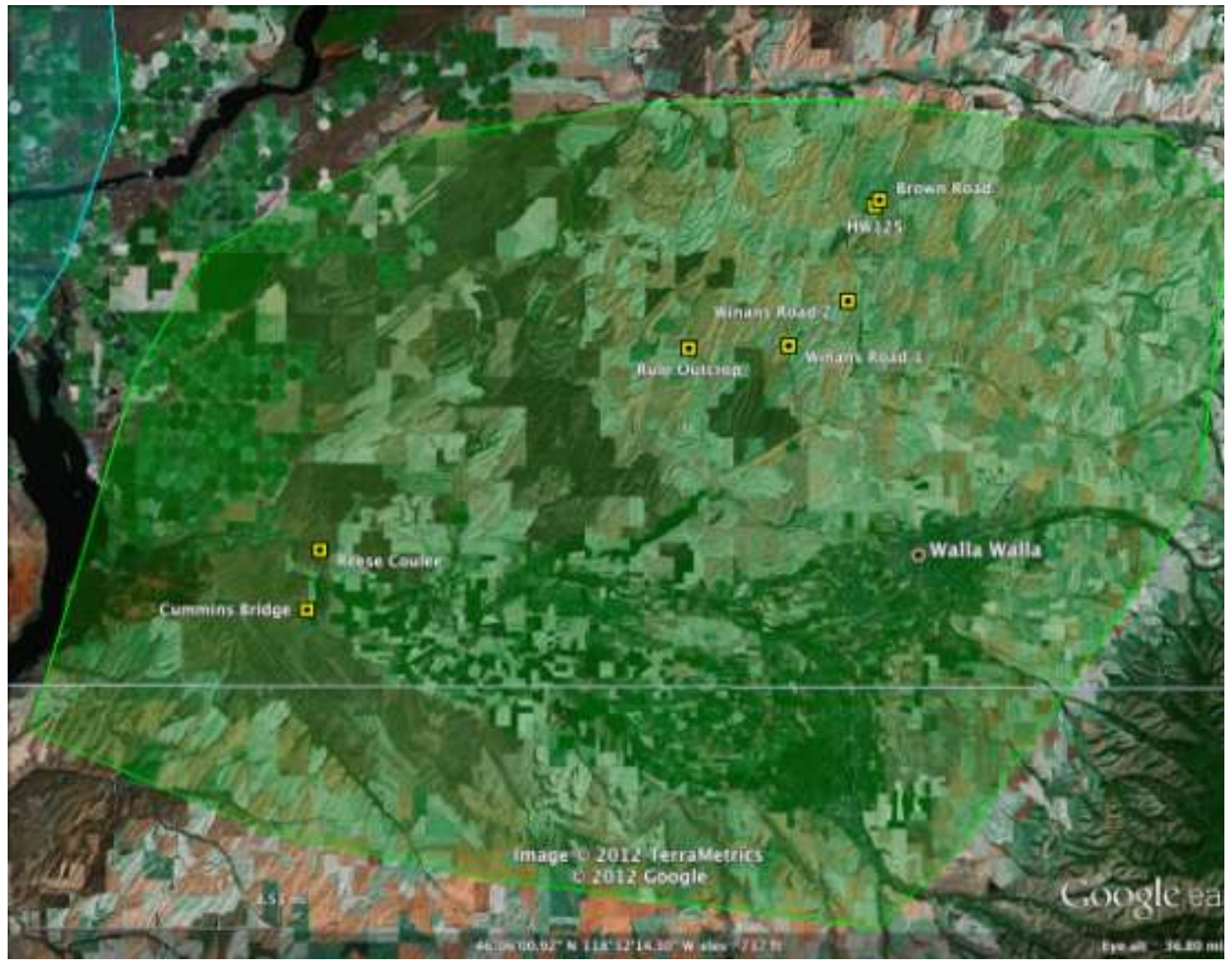

Figure 114 The Walla Walla Valley region with field sites labeled.

The Walla Walla Valley region has several field sites that contain evidence for multiple Ancient Cataclysmic Floods (Figure 114). The sites range in elevation from 117 to 311.2 meters. The Reese Coulee site has evidence for at least eight floods; one is at least Early Pleistocene in age based on reversed magnetic polarity. The other floods range from Early-Middle Pleistocene. Rulo loess outcrop has evidence for at least four Ancient Cataclysmic Floods that are probably Early-Middle Pleistocene in age, based on the presence of tephra dated to $>200 \mathrm{ka}$ and Stage II+ and III calcrete development. Winans Road 1, Winans Road 2, Brown Road, and HW125 are all closely located and stratigraphically correlated. They all have evidence of one 
Middle Pleistocene flood, and one Early Pleistocene flood is also evidenced at

Winans Road 1. Cummings Bridge site has evidence for at least one Middle Pleistocene flood.

\subsection{Othello Channels}

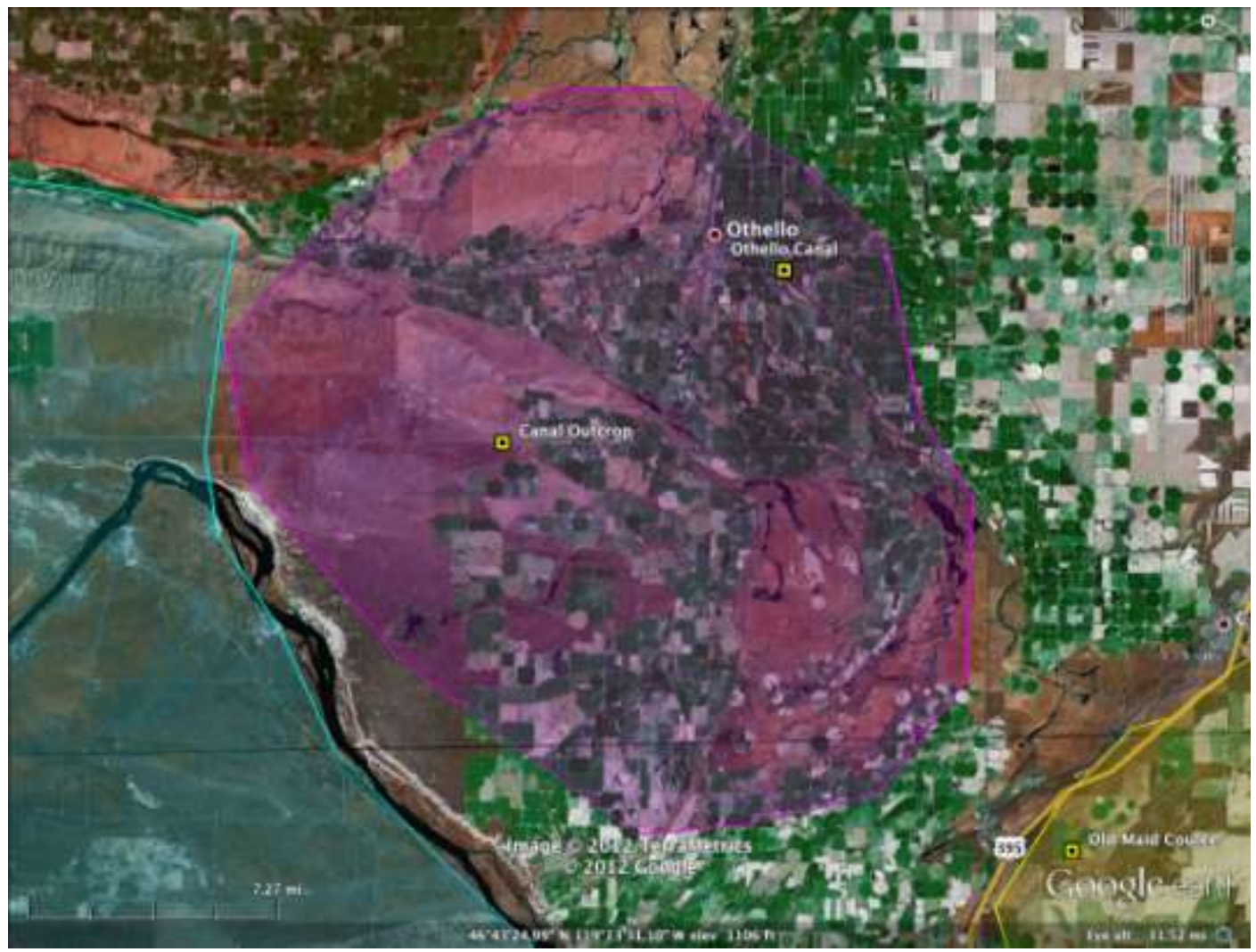

Figure 115 The Othello Channels region with field sites labeled.

The two new field sites discovered in the Othello Channels region, Othello

Canal and Canal Outcrop, are important (Figure 115). The elevations are 301 and 325 meters. Based on the similarity of elevations, proximity, and stratigraphy, these two sites are correlated to one another. These sites contain an extremely well developed calcrete paleosol, Stage III to III+ based on $\mathrm{CaCO}_{3}$ percentages, but Stage V based on morphology. They have one slackwater flood deposit below the paleosol, interpreted as Early Pleistocene in age and possibly one of the oldest preserved 
Ancient Cataclysmic Flood deposits. These slackwater deposits will be tested for magnetic reversals in the winter of 2012-2013. Flood waters may have gotten diverted into these channels, lowered in energy, and deposited finer-grained sediments.

\subsection{Quincy Basin}

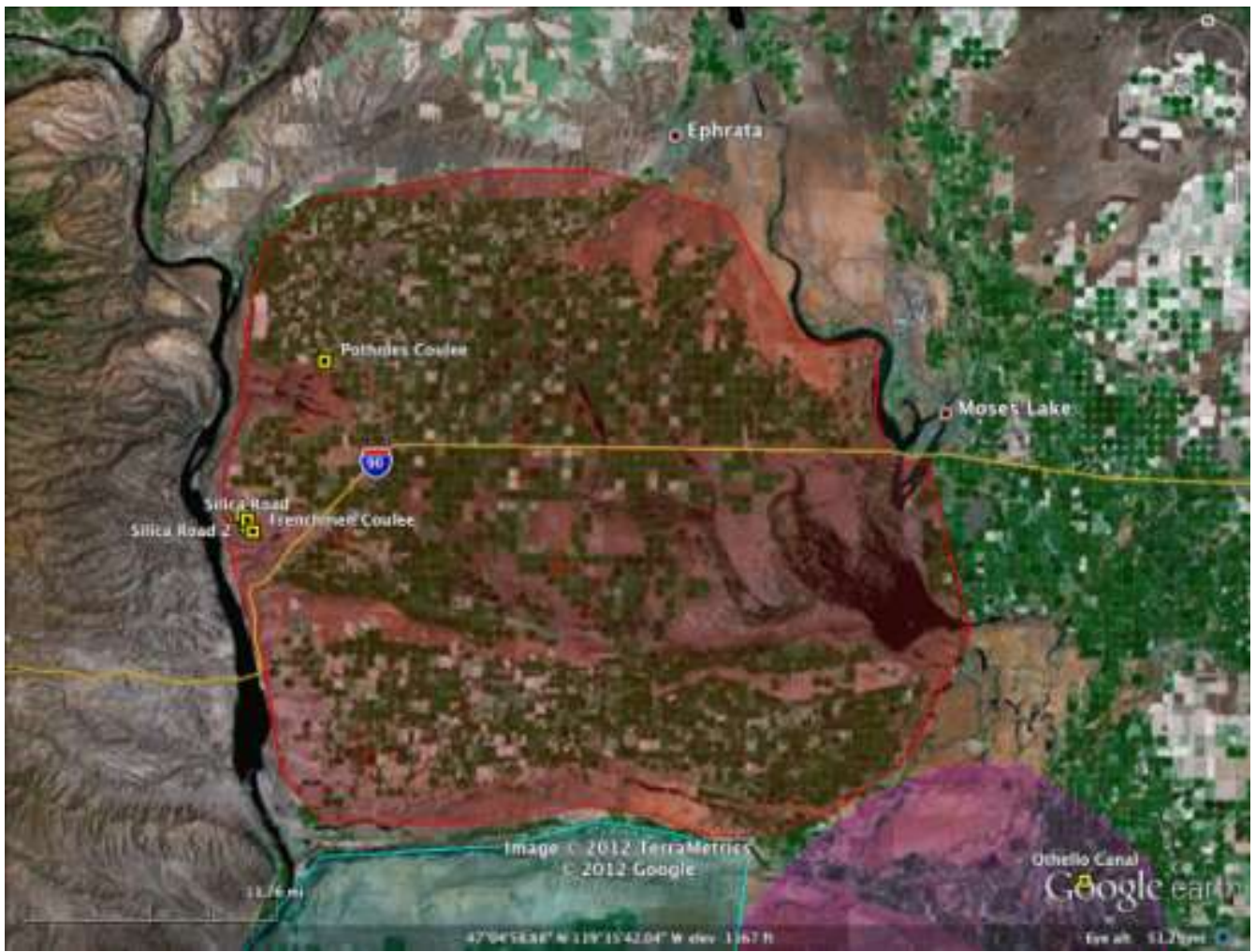

Figure 116 The Quincy Basin region with field sites labeled.

Ancient Cataclysmic Flood deposits in the Quincy Basin region are scarce (Figure 114). Potholes Coulee, Frenchmen Coulee, and Silica Road all contain late stage (Stages 2 and 3) calcrete paleosol development. The elevation ranges from 388 to 413 meters. Potholes Coulee has evidence for one Early Pleistocene and one Early-Middle Pleistocene, based on the late stage soil development. Flood deposits 
are not present at Frenchmen Coulee or Silica Road, but they both contain late stage paleosols that could correlate to those present at Potholes Coulee, mainly Middle Pleistocene.

\subsection{Cheney-Palouse Scabland}

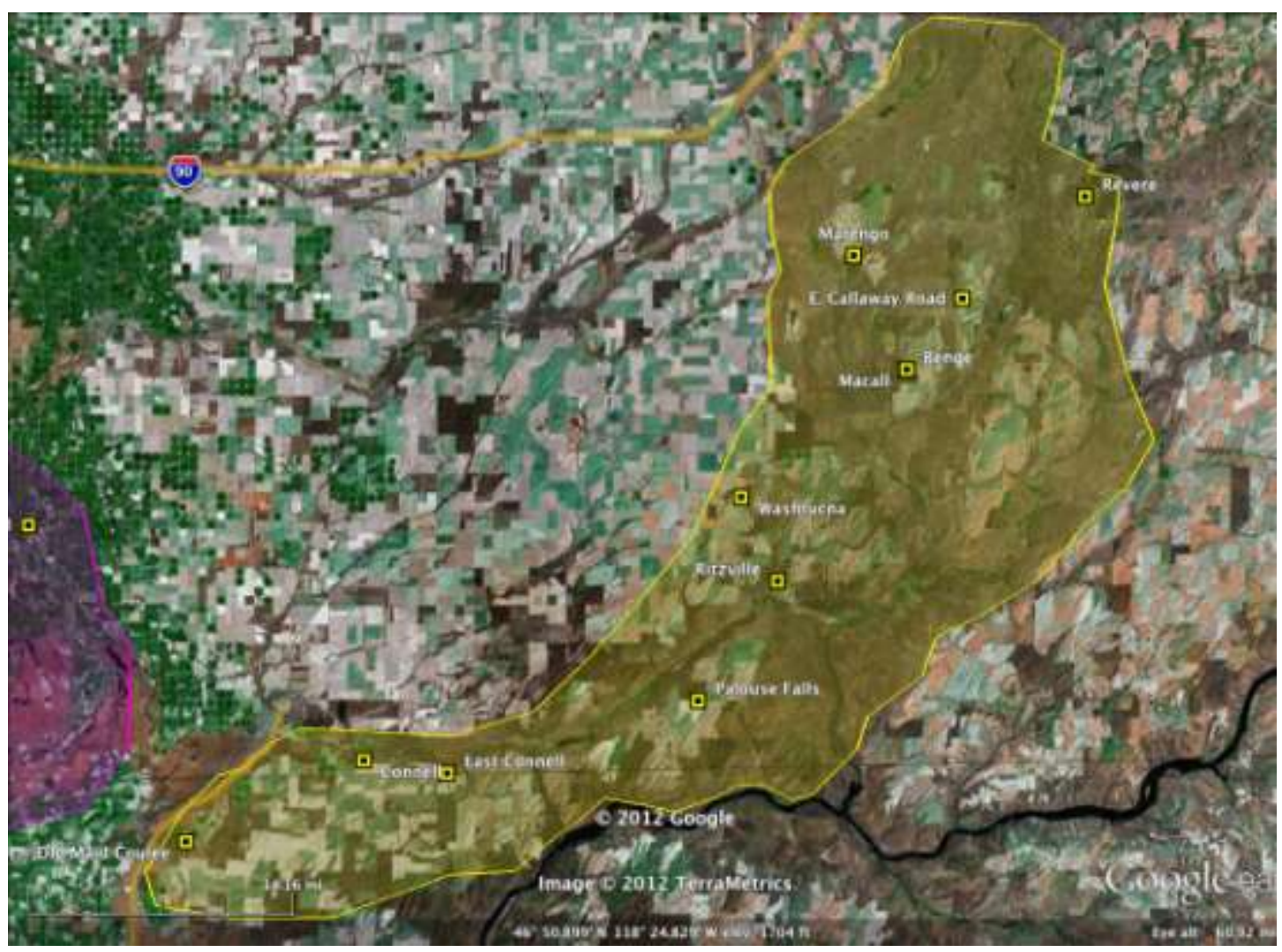

Figure 117 The Cheney-Palouse region with field sites labeled.

The Cheney-Palouse Scabland is one of the most highly eroded regions in the Channeled Scablands(Figure 117). It is the closest area to Glacial Lake Missoula, and floods were probably high velocity when they scoured this area. Evidence of Ancient Cataclysmic Floods in this area should be preserved at higher elevations. Field sites in the northeastern section of the region (Marengo, Benge, Macall, Revere, and E. Callaway Road) are located at elevations between 493.5 and 524.9 meters. The sites 
(except Marengo, which contained no evidence) contained paleosols with Stage II, II+, and III calcrete development. Benge has evidence for three Early Pleistocene floods and reversed magnetic polarity, as well as one Middle Pleistocene flood. Evidence for one Early Pleistocene flood and reversed magnetic polarity in sediments at Macall correlates to the deposits at Benge. Revere has one gravelly Early Pleistocene flood deposit and evidence for two more Middle Pleistocene floods; the Early Pleistocene flood correlates to Macall and Benge. The outcrop on East E. Callaway Road contains evidence in the loess for one Middle Pleistocene flood which, based on proximity and elevation, probably correlates to Benge also.

The field sites in the middle and lower sections of the Cheney-Palouse region are much lower in elevation, between 277 and 501 meters. The sites contain Stage II-IV calcrete development in paleosols. Three of the sites have preserved ash layers with Mount St. Helens set "C" tephra, dated to 36 ka calendar years. Evidence suggests one Middle Pleistocene flood deposit that is probably correlated at the sites: Washtucna, Ritzville, Palouse Falls, Connell, and East Connell.

Elevation of field sites in the region decreases from northeast to southwest. The Old Maid Coulee site, at the very southwestern edge of the region is the lowest in elevation, at 81.7 meters. Reversed magnetic polarity has been measured in sediments at the site, and there is one preserved Ancient Flood Deposit (Bjornstad, 2001).

\subsection{Age Correlation}


The earliest loess strata in the Palouse Formation was deposited in the Early Pleistocene, >1.5 Ma (Bjornstad, 2001). Table 29 lists the field sites according to their evidence for Early, Middle, or Late Pleistocene Missoula Flood deposits. Sixteen field sites show evidence for Early Pleistocene flooding (Figure 118).

Table 29 Field sites with evidence for flooding throughout the Pleistocene. If more than one event is displayed at the site, the number is in parentheses. The highlighted sites have evidence for both Early and Middle Pleistocene floods.

\begin{tabular}{|c|c|c|c|c|}
\hline Site & $\begin{array}{c}\text { Early } \\
\text { Pleistocene }\end{array}$ & $\begin{array}{c}\text { Middle } \\
\text { Pleistocene }\end{array}$ & $\begin{array}{c}\text { Late } \\
\text { Pleistocene }\end{array}$ & Deposit Type \\
\hline Avery Gravel Pit & & & $\mathbf{x}$ & high energy gravels \\
\hline St. Petersburg Bar & & & $\mathbf{x}$ & high energy gravels \\
\hline Fairbanks Farm & & & $\mathbf{x}$ & high energy gravels \\
\hline Arlington & & & $x$ & high energy gravels \\
\hline The Dalles & $\mathbf{x}$ & $\mathbf{x}$ & & $\begin{array}{c}\text { low energy slackwater } \\
\text { deposit }\end{array}$ \\
\hline Cummins Bridge & & $\mathbf{x}$ & & high energy gravels \\
\hline Reese Coulee & $x$ & $x$ & & high energy gravels \\
\hline Rulo Outcrop & & $\mathbf{x}$ & & loess \\
\hline Winans Road 1 & $\mathbf{x}$ & $\mathbf{x}$ & & $\begin{array}{c}\text { low energy slackwater } \\
\text { deposit }\end{array}$ \\
\hline Winans Road 2 & & $\mathbf{x}$ & & $\begin{array}{c}\text { low energy slackwater } \\
\text { deposit }\end{array}$ \\
\hline HW125 & & $\mathbf{x}$ & & $\begin{array}{c}\text { low energy slackwater } \\
\text { deposit }\end{array}$ \\
\hline Brown Road & & $\mathbf{x}$ & & $\begin{array}{c}\text { low energy slackwater } \\
\text { deposit }\end{array}$ \\
\hline Cold Creek Bar & $x$ & $\mathbf{x}$ & & high energy gravels \\
\hline Poplar Heights & $\mathbf{x}$ & & & high energy gravels \\
\hline Leslie Road & $x$ & $\mathbf{x}$ & & high energy gravels \\
\hline $\begin{array}{l}\text { South Bombing } \\
\text { Range Rd. }\end{array}$ & & $\mathbf{x}$ & & high energy gravels \\
\hline Yakima Bluffs & $\mathbf{x}$ & $\mathbf{x}$ & & $\begin{array}{l}\text { high energy gravels and } \\
\text { low energy rhythmites }\end{array}$ \\
\hline Field Rd. & & $\mathbf{x}$ & & high energy gravels \\
\hline FMEF & $x$ & $\mathbf{x}$ & & high energy gravels \\
\hline Canal Outcrop & $\mathbf{x}$ & & & $\begin{array}{c}\text { low energy slackwater } \\
\text { deposit }\end{array}$ \\
\hline Othello Canal & $\mathbf{x}$ & & & $\begin{array}{c}\text { low energy slackwater } \\
\text { deposit }\end{array}$ \\
\hline Potholes Coulee & $x$ & $\mathbf{x}$ & & high energy gravels and \\
\hline
\end{tabular}




\begin{tabular}{|l|c|c|c|c|}
\hline & & & & $\begin{array}{c}\text { low energy slackwater } \\
\text { deposits }\end{array}$ \\
\hline Frenchmen Coulee & & x & & $\begin{array}{c}\text { low energy slackwater } \\
\text { deposit }\end{array}$ \\
\hline Silica Road & & x & & $\begin{array}{c}\text { low energy slackwater } \\
\text { deposit }\end{array}$ \\
\hline Benge & x & x & & loess \\
\hline Macall & $\mathbf{x}$ & & & high energy gravels \\
\hline Revere & x & & & high energy gravels \\
\hline Callaway Rd. & & $\mathbf{x}$ & & loess \\
\hline Washtucna & & $\mathbf{x}$ & & high energy gravels \\
\hline Ritzville & & $\mathbf{x}$ & & high energy gravels \\
\hline Palouse & & $\mathbf{x}$ & & $\begin{array}{c}\text { low energy slackwater } \\
\text { deposit }\end{array}$ \\
\hline Connell & & $\mathbf{x}$ & & high energy gravels \\
\hline East Connell & & & & high energy gravels \\
\hline Old Maid Coulee & $\mathbf{x}$ & &
\end{tabular}

Evidence for Early Pleistocene flooding is preserved at lower elevations where the typical stratigraphy is a massive late stage calcrete paleosol overlying a slackwater flood deposit. Some more gravel dominated flood deposits are also preserved at much higher elevations, where subsequent floodwaters could not have scoured all the evidence. The stratigraphy at multiple flood bars is Late Wisconsin deposits over Early Pleistocene deposits with reversed magnetic polarity. These flooding cycles have been slowly contributing to the build up of loess islands and gravel bars for at least 1.5 Myr. 


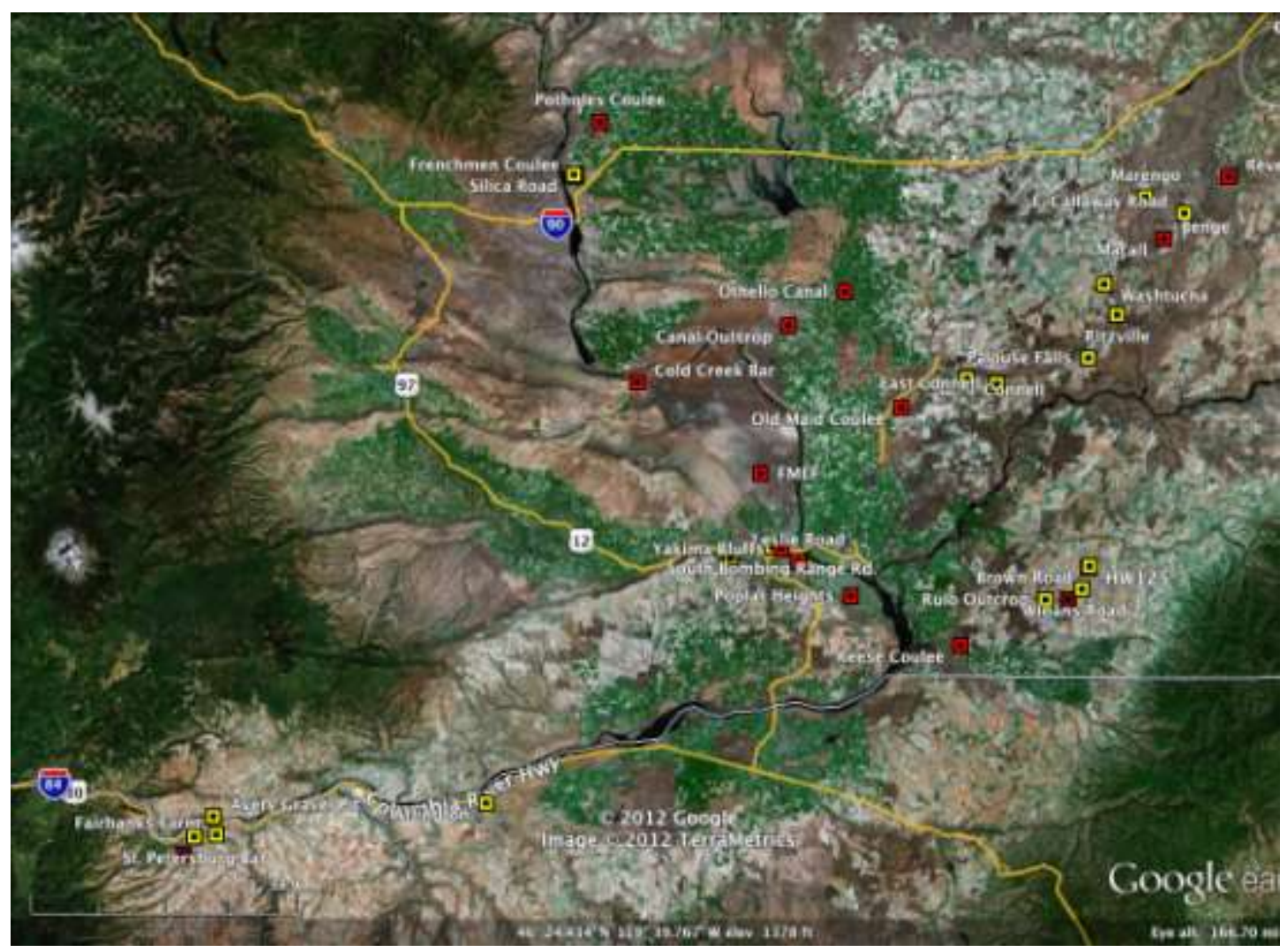

Figure 118 Field sites with evidence for Early Pleistocene flooding are in red and all other sites are yellow.

Bjornstad et al. (2001) suggests, “...on the basis of the number of pre-

Wisconsin flood localities that lie at or near the base of flood channels and bars, it is possible that the major flood features were established early in the Pleistocene, and later floods simply routed through the preexistent anastomosis." Sediment cores from Cold Creek bar show evidence of the slow aggradation of flood deposits starting in the Early Pleistocene on the basis of a thick sequence of reversed polarity over normal polarity deposits.

Ancient Cataclysmic Floods initiated in the Early Pleistocene and continued at unknown intervals until the Late Wisconsin. There are twenty-six field sites with evidence for Middle Pleistocene flooding (Figure 119). Evidence for Early 
Pleistocene Floods is also found at eleven of those twenty-six sites. Evidence for Early and Middle Pleistocene floods is found at wide distribution of elevations from 117 to 524 .

According to McDonald and Busacca (1988a), at least one secondary cycle (oxygen isotope stage 4) produced cataclysmic floods between 65 and $80 \mathrm{ka}$. Morrison (1991) estimated that there were as many as 44 major interglacial cycles during the Pleistocene. However, ice-damned lakes and subsequent flooding were not necessarily associated with each glacial advance, so that perhaps only the largest advances resulted in cataclysmic flooding. Depending on the interpretation of the number of floods associated with each glacial cycle, the total number of individual cataclysmic flood episodes could be in the hundreds.

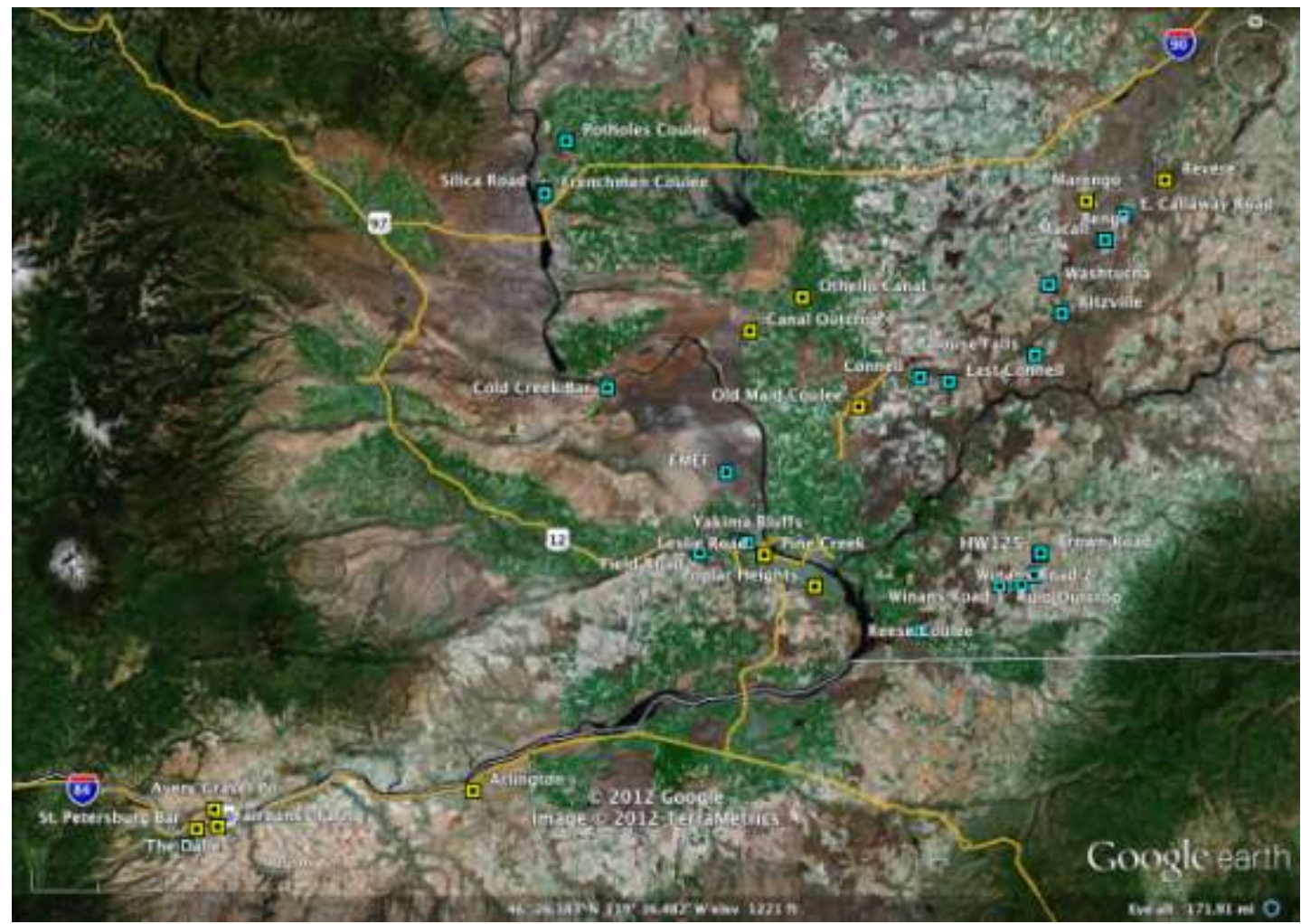

Figure 119 Field sites with evidence for Middle Pleistocene flooding are in aqua and all other sites are yellow. 
The lack of Mount St. Helens tephra and flood cut unconformities provides evidence for flood scouring between major deposition episodes. Due to the erosion, the time between flooding events and the total number of floods is unknown.

\subsection{Geographical Distribution of Floods}

Evidence for Early Pleistocene floods is present in all six geographical provinces. Most of the evidence is in the Pasco Basin (6 sites), Cheney Palouse Scabland (3), Walla Walla Valley (2), Othello Channels (2), Quincy Basin (1), and Columbia River Gorge (1). Evidence for Middle Pleistocene floods is present in all provinces except for Othello Channels. Most of the evidence is in the Cheney-Palouse Scablands province (10 sites), Walla Walla Valley (7), Pasco Basin (6), Quincy Basin (3), and Columbia River Gorge (1). It is noted that no Early or Middle Pleistocene deposits have been found in the Yakima Valley to the west, which has many Missoula Flood deposits.

Previous workers cite evidence for different origins for some of the Late Wisconsin Floods. Allen et al. (2009) hypothesizes that Moses Coulee and Grand Coulee (both located north of Quincy Basin) formed from the advance of the Okanogan Lobe of the Cordilleran Ice sheet. The Okanogan Lobe was thought to have dammed the Columbia River Channel. "The overflow from Glacial Lake Columbia was forced to the south, forming Moses Coulee. When the ice advanced further, the overflow was then moved into the next drainage to the east forming the Grand Coulee" (Allen et al., 2009). Both coulees were later modified by the Missoula 
Floods. Moses Coulee and Grand Coulee could have been formed much earlier in the Pleistocene than even suggested by Allen et al. (2009).

Waitt (1977) cites evidence for cataclysmic flooding coming from the Columbia River in the form of ice-rafted erratics and upvalley-dipping crossbeds in gravels. However, Waitt states that the Okanogan lobe was blocking the Columbia River until the Late Wisconsin. If some of the interglacial retreats were large enough and glacial advances small enough, this could have been a source for floods much earlier in the Pleistocene. Floods could also have originated as outbursts from beneath the Cordilleran ice sheet itself (Shaw et al., 1999).

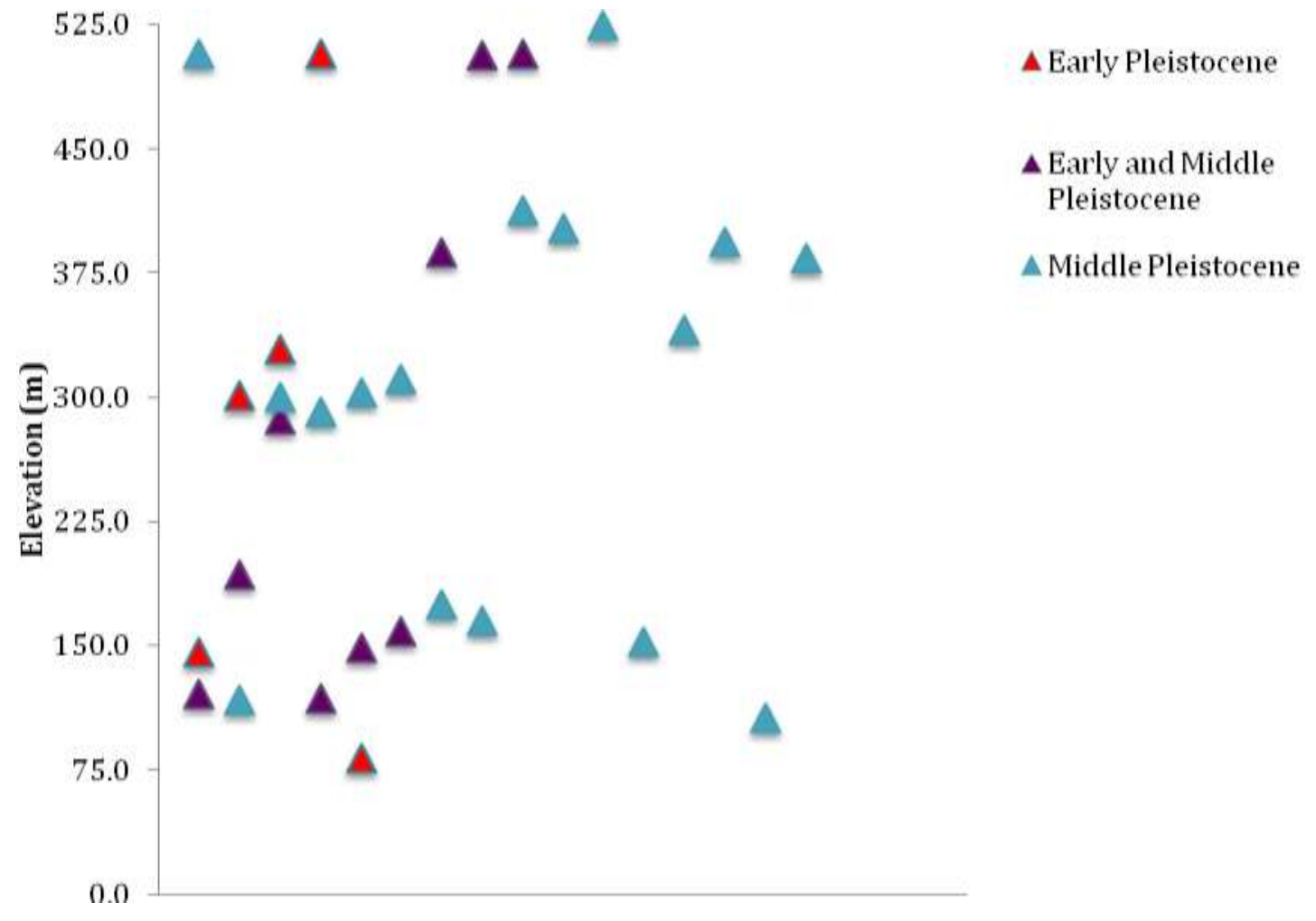

Figure 120 Graph showing elevations flood deposits of different ages, the triangles represent field sites. 
Evidence for Early and Middle Pleistocene floods is present over a wide distribution of elevations from 117 to 524 meters (Figure 120). The deposits are present at various elevations, however; most of the Early Plesitocene deposits are present at either the lowest or highest elevations (in places where subsequent floods could not have eroded them or have only eroded away overlying Middle Pleistocene deposits. Middle Pleistocene deposits are found at all elevations. 


\section{Chapter 6: Conclusions}

The Missoula Floods were one of the greatest sets of geologic events in Earth's recent history. The Floods occurred during the late-Wisconsin glaciation, 1518 ka in calendar years (Allen et al., 2009). The Missoula Floods eroded much of the evidence of previous floods. However, many geologists who have studied the Missoula Floods have documented evidence of much older flood deposits at certain localities in the channeled scablands of Eastern Washington and Oregon. These old floods are termed the Ancient Cataclysmic Floods by Allen et al. (2009). The pre-late Wisconsin Ancient Cataclysmic floods occurred during the Illinoian glaciation (oxygen isotope stage 6) and throughout the Pleistocene, approximately the last 2.6 Ma. I visited most of the field sites that were analyzed by other workers including: Baker and Nummedal (1978), Patton and Baker (1978), Busacca et al. (1989), Baker et al. (1991), Kiver et al. (1991), Fecht et al. (1999), Bjornstad et al. (2001), Spencer and Jaffee (2002), Bjornstad (2006), Cordero (1997), and Gastineau (2011). There are a total of 29 field sites studied in this thesis. Four of the sites are modern gravel pits, studied for a basis of comparison of "Missoula Flood" deposits to "Ancient Cataclysmic" flood deposits. Eleven of the sites are newly discovered possible Ancient Cataclysmic Flood sites. Fourteen sites were previous described in literature.

\subsection{Calcrete Paleosols}

Calcrete paleosols are a major criteria used for the relative age dating of Ancient Cataclysmic Floods. There is a direct correlation with the amount of soil 
development in an overlying paleosol and the age of the flood deposit below. According to a personal communication with Busacca (1997) cited in Cordero's thesis (1997) carbonate development Stage II to IV takes between 20,000 to 100,000 years to form; therefore, paleosols with $\geq$ Stage II development are older than the Missoula Floods. A total of 19 sites have calcrete paleosols, many with multiple paleosols, which were analyzed to determine the stage of $\mathrm{CaCO}_{3}$ development Table 31). Eight sites have paleosols with Stage II development (3.011.9\% $\mathrm{CaCO}_{3}$ ): Rulo Outcrop, Potholes Coulee, Leslie Road, Benge, E. Callaway Road, Collier Coulee, Plaouse, and Connell. Five sites have paleosols with Stage II+ development (12.0-16.9\% $\mathrm{CaCO}_{3}$ ): Brown Road, Leslie Road, Benge, Reese Coulee, and Connell. Fourteen sites have paleosols with Stage III development (17.0-34.9\% $\mathrm{CaCO}_{3}$ ): The Dalles, Rulo Outcrop, Winans Road 1, Poplar Heights, Yakima Bluffs, Canal Outcrop, Othello Canal, Reese Coulee, Potholes Coulee, E. Callaway Road, Frenchmen Coulee, Macall, Ritzville, and East Connell. One site has a paleosol with Stage III+ development (35.0-49.9\% $\mathrm{CaCO}_{3}$ ): Othello Canal. Based on morphology, Othello Canal might be classified as Stage V calcrete development, I interpret Othello Canal and Canal Outcrop to be two of the oldest preserved flood deposits.

\subsection{Early Pleistocene deposits}

Ancient Cataclysmic Flooding initiated in the Early Pleistocene at least as early as 1.5 Ma and continued at unknown intervals until the Late Wisconsin. Sixteen field sites show evidence for Early Pleistocene flooding. Evidence for Early Pleistocene floods is present in all six geographical provinces. Most of the evidence 
is in the Pasco Basin (6 sites), Cheney Palouse Scabland (3), Walla Walla Valley (2), Othello Channels (2), Quincy Basin (1), and Columbia River Gorge (1). The main basis of distinction for Early Pleistocene versus Middle Pleistocene is reversed magnetic polarity, measured in slackwater deposits and loess. However, some sites that have not been tested for reversed magnetic polarity are still classified as Early Pleistocene, such as Othello Canal,Canal Outcrop, and the lower Dalles paleosols. They will be tested for paleomagnetic reversals in the winter of 2012-2013. The sites were classified on the basis of very thick and massive calcrete paleosols with Stage III and III+ soil development. Most of the Early Pleistocene deposits are at very low elevations, below $150 \mathrm{~m}$. The typical stratigraphy is a massive late stage calcrete paleosol overlying a slackwater flood deposit. Gravel dominated flood deposits are preserved at much higher elevations, where subsequent floodwaters could not have scoured all the evidence. No Early Pleistocene deposits were found in the Yakima Valley.

\subsection{Middle Pleistocene deposits}

There are twenty-six field sites with evidence for Middle Pleistocene flooding (Figure 119). Eleven of those twenty-six sites also show evidence for Early Pleistocene Floods. Evidence for Middle Pleistocene floods is present in all provinces except for Othello Channels and the Yakima Valley. Most of the evidence is in the Cheney-Palouse Scablands province (10 sites), Walla Walla Valley (7), Pasco Basin (6), Quincy Basin (3), and Columbia River Gorge (1). 
Sites that have been tested in this grouping exhibit normal magnetic polarity. There are fewer preserved Middle Pleistocene deposits in the lowest elevation regions of Pasco Basin and Othello Channels because only the Early Pleistocene flood deposits have remained in those valleys. The Middle Pleistocene deposits are not present in the lower elevations; due to subsequent erosion, only the earliest flood deposits have remained in those valleys.

\subsection{Calcrete formation in Missoula Flood gravel deposits in quarries}

The Missoula Flood deposits were sampled at a few quarries and gravel pits in the Columbia River Gorge region. Multiple samples were collected at varying elevations at each quarry. The samples from Avery Gravel Pit ranged from 0.5-1.9\% $\mathrm{CaCO}_{3}$, or Stage I carbonate development. St. Petersburg bar samples contained 1.71.8\% carbonate, Stage I. Fairbanks Farm samples contained 0.8-1.7\% $\mathrm{CaCO}_{3}$, Stage I. The sample from Arlington, which is highest in elevation and the furthest east of the modern sites, contained 2.0\% $\mathrm{CaCO}_{3}$, Stage I development. Therefore, we do have calcrete formation in Missoula Flood deposits, contain a maximum of $2.0 \% \mathrm{CaCO}_{3}$ and only Stage I development. Much more time is necessary to develop Stage II-IV.

\subsection{Big Picture of Calcrete Formation}

The Ancient Cataclysmic flood deposits at all the other field sites range from Stage I-III of $\mathrm{CaCO}_{3}$ development. Some of the field sites determined to be the earliest in age with the most overlying soil development (Stage III+), such as Othello Canal and Canal Outcrop, have accompanying flood deposits with the least amounts 
of $\mathrm{CaCO}_{3}$. Othello Canal and Canal Outcrop flood deposits contain 0.6-0.8\% $\mathrm{CaCO}_{3}$, Stage I development. At most sites with a prominent $\mathrm{CaCO}_{3}$ paleosol present, the underlying flood deposit is extremely leached of $\mathrm{CaCO}_{3}$, which is collected in the " $\mathrm{B}$ " soil horizon.

In the opposing case, where an Ancient Flood deposit remains but the overlying paleosol has either been removed by man or eroded, the stage of $\mathrm{CaCO}_{3}$ development in the flood deposit is much higher. Such is the case at Field Road Site, Old Maid Coulee, and Winans Road 1, where the once existing overlying paleosols have been removed at some point. The flood deposit at Field Road contains 16.5\% $\mathrm{CaCO}_{3}$, Stage III development and the diamict at Winans Road 1 contains $13.7 \%$ $\mathrm{CaCO}_{3}$, Stage III development. The flood deposit at Old Maid Coulee is thought to have been more recently exposed based on recent literature (Bjornstad 2001, 2006) mentioning the presence of a paleosol. The flood deposit contains only $4.25 \% \mathrm{CaCO}_{3}$ today.

Flooding occurred throughout the Pleistocene which is broken up into three age ranges: Early Pleistocene from 2.58 Ma - 781 ka, Middle Pleistocene from 126781 ka, and Late Pleistocene from 126 ka to 11,700 (Morrison, 1991). However, all pre-Missoula Flood (15 - 18 ka) deposits were termed "Middle Pleistocene" in this thesis to differentiate them from the Late Pleistocene Missoula Flood deposits. Early to Middle Pleistocene deposits ranged from Stage II to III+ soil development. Late Pleistocene Missoula Flood deposits contained only Stage $\mathrm{I} \mathrm{CaCO}_{3}$. Stage I development of $\mathrm{CaCO}_{3}$ in paleosols takes 15,000 years to form; therefore, paleosols with $\geq$ Stage II development are older than the Missoula Floods. 


\subsection{Particle size grading curve for a loess vs. flood deposit}

Many paleosols are formed in fine-grained deposits where little to no gravels, which could be slackwater flood deposits or windblown loess. Slackwater flood deposits should have more quartz sand and less overall silt. Particle size analysis was conducted on two samples using the pipette method (Gee and Bauder, 1986). The slackwater deposit tested for grain size is from Othello Canal (OC1), which lies below a Stage V calcrete paleosol. The loess deposit tested is from the most famous loess site, Washtucna (WCC1). The slackwater deposit contains much more quartz sand (26.1\%) than the loess deposit (13.3\%). The WCC1 loess deposit also contains 15.4\% more silt than OC1 slackwater deposit.

Table 30 Particle size results of a slackwater deposit (OC1) and a loess deposit (WCC1).

\begin{tabular}{|c|c|c|}
\hline & OC1 slackwater & WCC1 loess \\
\hline sand & $29.1 \%$ & $13.3 \%$ \\
\hline silt & $67.5 \%$ & $82.8 \%$ \\
\hline clay & $3.5 \%$ & $3.9 \%$ \\
\hline
\end{tabular}


Table 31 Summary of elevation and calcrete development for each field site.

\begin{tabular}{|c|c|c|c|c|c|}
\hline Site & $\begin{array}{l}\text { Elevation } \\
\qquad(\mathrm{m})\end{array}$ & $\begin{array}{l}\text { Flood } \\
\text { deposit }\end{array}$ & Loess & $\begin{array}{l}\text { Calcrete } \\
\text { paleosol }\end{array}$ & Interpretation \\
\hline \multicolumn{6}{|c|}{ Columbia River Gorge } \\
\hline Avery Gravel Pit & 80.0 & Eight Stage I & & & Missoula Flood deposits \\
\hline St. Petersburg Bar & 120.7 & Three Stage I & & & Missoula Flood deposits \\
\hline Fairbanks Farm & 158.5 & Two Stage I & & & Missoula Flood deposits \\
\hline Arlington & 164.0 & One Stage I & & & \\
\hline The Dalles & 284.0 & & & $\begin{array}{c}\text { One Stage II, } \\
\text { Three Stage III, } \\
\text { One Stage III+ } \\
\end{array}$ & $\begin{array}{c}\text { Two Early Pleistocene, } \\
\text { three Early-Middle } \\
\text { Pleistocene }\end{array}$ \\
\hline \multicolumn{6}{|l|}{ Walla Walla Valley } \\
\hline Cummins Bridge & 117.0 & & & & one Middle Pleistocene \\
\hline Reese Coulee & 193.0 & One Stage I & & $\begin{array}{l}\text { One Stage II+, } \\
\text { One Stage III }\end{array}$ & $\begin{array}{l}\text { at least eight separate } \\
\text { calcrete paleosols (each } \\
\text { overlies flood deposit), at } \\
\text { least one Early Pleistocene } \\
\text { and many more Early- } \\
\text { Middle Pleistocene }\end{array}$ \\
\hline Rulo Outcrop & 299.9 & & $\begin{array}{c}\text { One Stage I, } \\
\text { Three Stage } \\
\text { II+ }\end{array}$ & $\begin{array}{l}\text { One Stage III, } \\
\text { One Stage II }\end{array}$ & $\begin{array}{l}\text { multiple middle } \\
\text { Pleistocene }\end{array}$ \\
\hline Winans Road 1 & 286.2 & Two Stage III & & One Stage III & $\begin{array}{l}\text { one Early Pleistocene and } \\
\text { one Middle Pleistocene }\end{array}$ \\
\hline Winans Road 2 & 291.1 & & & & one Middle Pleistocene \\
\hline HW125 & 302.7 & & & & one Middle Pleistocene \\
\hline
\end{tabular}




\begin{tabular}{|c|c|c|c|c|}
\hline Brown Road & 311.2 & & One Stage II+ & one Middle Pleistocene \\
\hline \multicolumn{5}{|l|}{ Pasco Basin } \\
\hline Cold Creek Bar & 313.9 & & & $\begin{array}{l}\text { at least one Early } \\
\text { Pleistocene, more Early- } \\
\text { middle Pleistocene }\end{array}$ \\
\hline Poplar Heights & 146.0 & One Stage I & One Stage III & one Early Pleistocene \\
\hline Leslie Road & 118.0 & Two Stage I & $\begin{array}{l}\text { One Stage II, } \\
\text { One Stage II+ }\end{array}$ & $\begin{array}{l}\text { one Early Pleistocene, one } \\
\text { Middle/Late Pleistocene }\end{array}$ \\
\hline $\begin{array}{l}\text { South Bombing } \\
\text { Range Rd. }\end{array}$ & 174.7 & & & one Middle Pleistocene \\
\hline Yakima Bluffs & 148.7 & $\begin{array}{ll}\text { One Stage I, Two Stage I } \\
\text { One Stage II }\end{array}$ & Three Stage III & $\begin{array}{c}12 \text { Early-Middle } \\
\text { Pleistocene rhythmites, } \\
\text { and two Middle } \\
\text { Pleistocene gravelly flood } \\
\text { deposits }\end{array}$ \\
\hline Field Rd. & 165.2 & One Stage III & & $\begin{array}{l}\text { one Middle Pleistocene } \\
\text { gravelly flood deposit }\end{array}$ \\
\hline FMEF & 158.5 & & & one Middle Pleistocene \\
\hline \multicolumn{5}{|l|}{ Othello Channels } \\
\hline Canal Outcrop & 301.0 & One Stage I & One Stage III & $\begin{array}{l}\text { one Early Pleistocene } \\
\text { (correlates to Othello) }\end{array}$ \\
\hline Othello Canal & 329.0 & One Stage I & $\begin{array}{c}\text { One Stage III, } \\
\text { One Stage III+ }\end{array}$ & $\begin{array}{l}\text { one Early Pleistocene } \\
\text { slackwater below }\end{array}$ \\
\hline \multicolumn{5}{|l|}{ Quincy Basin } \\
\hline Potholes Coulee & 388.0 & $\begin{array}{l}\text { One Stage I, } \\
\text { One Stage II }\end{array}$ & $\begin{array}{l}\text { One Stage II, } \\
\text { One Stage III }\end{array}$ & $\begin{array}{c}\text { one Early Pleistocene and } \\
\text { one Early-Middle } \\
\text { Pleistocene }\end{array}$ \\
\hline
\end{tabular}




\begin{tabular}{|c|c|c|c|c|}
\hline Frenchmen Coulee & 413.0 & & One Stage III & $\begin{array}{c}\text { no flood deposit, } \\
\text { weathered bedrock below } \\
\text { paleosol }\end{array}$ \\
\hline Silica Road & 402.0 & & & one Middle Pleistocene \\
\hline \multicolumn{5}{|c|}{ Cheney-Palouse Scabland } \\
\hline Marengo & 493.5 & & & no deposit \\
\hline Revere & 507.2 & & & $\begin{array}{c}\text { one Early Pleistocene, one } \\
\text { Middle Pleistocene }\end{array}$ \\
\hline Benge & 506.6 & One Stage I & $\begin{array}{l}\text { Two Stage II, } \\
\text { Two Stage II+ }\end{array}$ & $\begin{array}{l}\text { three Early Pleistocene, } \\
\text { one Middle Pleistocene }\end{array}$ \\
\hline Macall & 507.2 & & One Stage III & one Early Pleistocene \\
\hline Revere & 507.2 & & & \\
\hline E. Callaway Rd. & 524.9 & $\begin{array}{c}\text { One Stage } \\
\mathrm{II}+ \\
\end{array}$ & $\begin{array}{l}\text { One Stage II, } \\
\text { One Stage III }\end{array}$ & one Middle Pleistocene \\
\hline Washtucna & 501.0 & Two Stage II & & one Middle Pleistocene \\
\hline Ritzville & 341.0 & Two Stage II & One Stage III & one Middle Pleistocene \\
\hline Palouse & 394.0 & One Stage I & One Stage II & one Middle Pleistocene \\
\hline Connell & 349.0 & & $\begin{array}{l}\text { One Stage II, } \\
\text { One Stage III }\end{array}$ & one Middle Pleistocene \\
\hline East Connell & 384.0 & & Two Stage III & one Middle Pleistocene \\
\hline Old Maid Coulee & 277.0 & One Stage II & & one Early Pleistocene \\
\hline
\end{tabular}




\section{Chapter 7: Future Work}

Although many scientists have studied the Missoula Floods extensively, it has only been in the last century that they have been known about. Most workers of the Missoula Floods have mentioned much older flood deposits. I have only begun to put together the story of the Ancient Cataclysmic Floods. More flood deposits, referenced by Kiver (1991), exist in the Northern part of the Scablands in the Spokane area. These deposits need to be studied, added to the database of existing flood deposits, and correlated to as many other deposits as possible. Once all known Ancient Flood deposits are accounted for, further investigations constraining the ages and origins of these flood deposits can be made. Additionally, more new sites need to be searched for along the Columbia Gorge and Willamette Valley as well as the Channeled Scablands and the Yakima Valley.

The use of soil development as an age indicator has proved useful. The percentage of $\mathrm{CaCO}_{3}$ in sample replicates, determined using the Chittick method, shows extremely low amounts of error. However, the accuracy of determining the age based on this percentage is unknown. A study in another arid environment using calcrete paleosols of known ages should be conducted. U-series dating of all of the calcretes would also be useful to test the stage of development to age correlation.

Only a few sites have been tested for reversed magnetic polarity. The remaining Early Pleistocene and some of the early-Middle Pleistocene deposits need tested; especially the Othello Canal, Canal Outcrop, and The Dalles sites. 
Also, only a few sites have been run for particle size analysis, some by me and some by others. The remaining sites with slackwater deposits should be tested to differentiate them from loess, especially the Yakima Bluffs rhythmites. Specifically, the following slackwater deposit and rhythmite samples should all be tested for particle size: PC4, YB5, YB6, YB7, WR11, WR13, C03, C03.5, HW2603, R01.

The Ice Age Floods National Geologic Trail was first established in 2011 (Ice Age Flood Institute, 2011). The trail is culturally important in the Northwest and brings together evidence of the Missoula Floods. The trail should be updated in order to include the history of the Ancient Cataclysmic Floods. The trail spans four states and is a great way to educate the public about the Missoula and Ancient Cataclysmic Floods. 


\section{References}

Allen, J.E., Burns, M., Scott, S.F., 2009, Cataclysms on the Columbia: The Great Missoula Floods (Rev. 2nd ed.). Portland, Oregon: Ooligan Press, 204 p.

Atwater, B.F., 1984, Periodic floods from Glacial Lake Missoula in the Sanpoil Arm of the Glacial Lake Columbia, Northeastern Washington: Geology, v. 12, n. 8, p. 464-467.

Baker, V.R., 1973, Erosional forms and processes for the catastrophic Pleistocene Missoula Floods in eastern Washington, in Morrisawa, M., ed., Fluvial Geomorphology: Publications in Geomorphology, State University of New York, Binghamton, New York, p. 123-148.

Baker, V.R., Bjornstad, B.N., Busacca, A.J., Fecht, K.R., Kiver, E.P., Moody, U.L., Rigby, J.G., Stradling, D.F. and Tallman, A.M., 1991, Quaternary geology of the Columbia Plateau, in Morrison, R.B., ed., Quaternary Nonglacial Geology, Conterminous U.S., DNAG [Decade of North Amer. Geology], Geology of North America, Geological Society of America, V. K-2, p. 215-250.

Baker, V.R. and Nummedal, D., eds., 1978, The Channeled Scabland; A Guide to the Geomorphology of the Columbia Basin, Washington, National Aeronautics and Space Administration, $186 \mathrm{p}$.

Benito, G. and O'Connor, J.E., 2003, Number and size of last-glacial Missoula Floods in the Columbia River valley between the Pasco Basin, Washington, and Portland, Oregon, Geological Society of America Bulletin, v. 115, no. 5, p. 624638.

Berendsen H., C.K., H.W., 2004, The Holocene Rhine-Meuse Delta, Netherlands, Vrije Universiteit Amsterdam, Amsterdam, Netherlands, p. 131-189.

Birkeland, P.W., 1999, Soils and Geomorphology [3d ed.], New York, Oxford University Press, $430 \mathrm{p}$. 
Bjornstad, B.N., 2006, On the Trail of the Ice Age Floods, A Geological Field Guide to the Mid-Columbian Basin, Keokee Books, 320 p.

Bjornstad, B.N., Fecht, K.R., and Pluhar, C.J. , 2001, Long history of pre-Wisconsin, Ice-Age Floods: Evidence from southeastern Washington State, Journal of Geology, v. 109, p. 695713

Bretz, J H., 1923, The channeled scabland of the Columbia Plateau: Journal of Geology, v. 31, p. 617-649.

Bretz, J H., 1928, The channeled scabland of eastern Washington: Geology Review, v. 18, p. 446-477.

Busacca, A.J. and McDonald, E.V., 1994, Regional sedimentation of late Quaternary loess on the Columbia Plateau: sediment source areas and loess distribution patterns, Bulletin 80, Washington Divisions of Geology and Earth Resources, p. 181-190.

Busacca, A.J., McDonald, E.V., and Baker, V.R., 1989, The record of pre-late Wisconsin floods and late Wisconsin flood features in the Cheney-Palouse Scabland Field trips for the 28th International Geological Congress, United States: American Geophysical Union : Washington, D.C., pp. 57-62.

Carson, R.J., and Pogue, K.R., 1996, Flood Basalts and Glacier Floods-Roadside Geology of Parts of Walla Walla, Franklin, and Columbia Counties, Washington, Washington Division of Geology and Earth Resources Information Circular 90, 47 p.

Clague, J.J., Armstrong, J.E., and Mathews, W.H., 1980, Advance of the Late Wisconsin Cordilleran Ice Sheet in southern British Columbia Since 22,000 Yr. BP, Quaternary Research, v. 13, p. 322-326.

Cordero, D.I., 1997, Early to Middle Pleistocene Catastrophic Flood Deposits, The Dalles, Oregon, Portland State University M.S. thesis, 162 p. 
Cox, A., 1973, Plate Tectonics and Geomagnetic Reversal, San Francisco, California: W. H. Freeman. p. 138-145, 222-228.

DeGrey, L., and Link, P.K., 1999, Lake Missoula Floods, Idaho State University. Digital Geology of Idaho: http://geology.isu.edu/Digital Geology Idaho/Module13 $/ \bmod 13 . h t m$

Dreimanis, A., 1962, Quantitative gastrometric determination of calcite and dolomite by using Chittick Apparatus: Journal of Sedimentary Petrology, v. 32, no. 3, p. 520-529.

Fecht, K. R. and Tallman, A.M., 1978, Bergmounds along the western margin of the Channeled Scablands, south- central Washington, Geological Society of America, Abstracts with Programs, v. 10, no. 7, p. 400.

Fecht, K.R., Bjornstad, B.N., Horton, D.G., Last, G.V., Reidel, S.P., and Lindsey, K.A., 1999, Clastic injection dikes of the Pasco Basin and vicinity: Geologic Atlas Series, BHI-01103, Rev. 0, Bechtel Hanford Company, Richland, Washington.

Gastineau, K., 2011, Sedimentology and age constraints of Pleistocene outburst flood-related deposits in the Palouse Hills, Southeastern Washington, Whitman College, Undergraduate honors thesis, $38 \mathrm{p}$.

Gee, G.W., and J.W., Bauder, 1986. Particle Size Analysis. In Klute, (ed.) Methods of Soil analysis- Part I Physical and mineralogical methods. American Society of Agronomy, Soil Science Society of America, Inc. Series in Agronomy 9: 383409.

Gile, L.H., Hawley, J.W., and Grossman, R.B., 1981, Soils and Geomorphology in the basin and range area of southern New Mexico: Guidebook to the Desert Project. New Mexico Bureau Mines Mineral Resources Memoir 39, 222 p.

Ice Age Flood Institute, 2011. http://www.iafi.org/trail.html 
Jaffee, M. and Spencer, P., 2000, Multiple floods many times over; the record of glacial outburst floods in southeastern Washington, Abstracts With Programs, Geological Society Of America, 32, 6, 21 p.

Johnson, R.G., 1982, Brunhes-Matuyama magnetic reversal dated at 790,000 yr B.P. by marine-astronomical correlations, Quaternary Research, 17, 2, pp. 135147.

Kiver, E.P., Moody, U.L., Rigby, J.G., and Stradling, D.F., 1991, Late Quaternary stratigraphy of the channeled scabland and adjacent areas, in Baker, V.R., Quaternary Geology of the Columbia Plateau, in Morrison, R.B., ed., Quaternary Nonglacial Geology, Conterminous U.S., DNAG [Decade of North Amer. Geology], Geology of North America, Geological Society of America, v. K-2, p. 238-250.

Laity, J., 2008, Deserts and Desert Environments, Environmental Systems and Global Change Series, United Kingdom: Wiley-Blackwell : Chichester, United Kingdom.

Machette, M.N., 1985, Calcic soils of the southwestern United States, Special Paper, Geological Society Of America, 203, pp. 1-21.

Machette, M., 1986, Calcium and magnesium carbonates, in Singer, M., and Janitzky, P., eds., Field and laboratory procedures used in a soil chronosequence study: U.S. Geological Survey Bulletin 1648, p. 30-33.

McDonald, E.V., and Busacca, A.J., 1988a, Record of pre-late Wisconsin giant floods in the channeled scabland interpreted from loess deposits, Geology, v. 16, p. 728731.

McDonald, E.V. and Busacca, A.J., 1988b, New evidence for middle Wisconsin glacial outburst flooding in the channeled scabland of eastern Washington, Geological Society of America, Abstracts with Programs, v.20, no. 7, p. A373.

Morrison, R.B., 1991, Introduction. In Morrison, R. B., ed. Quaternary Nonglacial Geology. Conterminous U.S. Geology of North America. Boulder, Colorado, Geological Society of America K-2: p. 1-12. 
Mullineaux, D. R., Wilcox, R.E., Ebaugh, W.F., Fryxell, R. and Rubin, M., 1978, Age of last major scabland flood of the Columbia River Plateau in eastern Washington: Quaternary Research, v. 10, p. 171-180.

O'Connor, J.E., Waitt, R., Johnston, D., Benito, G., Cordero, D., \& Burns, S.F., 1995, Beyond the Channeled Scabland; a field trip to Missoula flood features in the Columbia, Yakima, and Walla Walla valleys of Washington and Oregon, Part 2; Field trip, day one, Oregon Geology, 57, 4, pp. 75-86.

Parfit, M., 1995, The floods that carved the west. Smithsonian (0037-7333), v. 26 (1), p. 48.

Patton, P. and Baker, V.R., 1978, New evidence for pre-Wisconsin flooding in the channeled scabland of eastern Washington, Geology [Boulder], 6, 9, pp. 567571.

Reidel, S.P., and Hooper, P.P., 1989, Volcanism and Tectonism in the Columbia River Flood-Basalt Province. Geological Society of America, Special Paper 239, $386 \mathrm{p}$.

Reidel, S.P., Reynolds, K.D., and Horton, D.G., 1998, Immobilized low-activity waste site borehole 299-E17-21. PNNL-11957. Richland, Washington, Pacific Northwest National Laboratory.

Shaw, J., Munro-Stasiuk, M., Sawyer, B., Beaney, C., Lesermann, J., Masacchio, A., Rains, B., and Young, R.R., 1999, The Channeled Scabland: Back to Bretz? Geology, v. 27, p. 605-608.

Shroba, R.R., 1982, Soil B-horizon properties as age indicators for late Quaternary deposits along the Wasatch Front, north-central Utah. Geological Society of America, Abstracts with Programs, v14, 4, p. 233.

Smiley, T.L., Bryson, R.A., King, J.E., Kukla, G.J., and Smith, G.I., 1991, Quaternary paleoclimates, In Morrison, R.B., ed. Quaternary Nonglacial Geology. Conterminous U.S. Geology of North America. Boulder Colorado, Geological Society of America K-2: 13-44. 
Spencer, P.K., and Gilk, S., 1999. Correlation of pre-late Wisconsin catastrophic glacial flood deposits, Walla Walla County, Washington [abstract]: Geological Society of America Abstracts with Programs, v. 31, no. 6, p. A-97.

Spencer, P.K., and Jaffee, M.A., 2002, Pre-late Wisconsinan glacial outburst floods in southeastern Washington, The indirect record, Washington Geology, v. 30, no. $1 / 2$, p. 9-16.

Waitt, R.B., 1977, Glaciation and Catastrophic Flooding of the Columbia Plateau, Washington; Part 3, Columbia Valley, in Brown, E. H., and R. C. Ellis, eds., Geological Excursions in the Pacific Northwest, Geological Society of America, 1977 Annual Meeting, Seattle, published by Western Washington University, p. $411-412$.

Waitt, R. B., 1980, About forty last-glacial Lake Missoula jokulhlaups through southern Washington: Journal of Geology, v. 88, p. 653-679. 


\section{Appendices}

\section{Appendix A: $\mathrm{CaCO}_{3}$ analysis, Chittick methods}

The Chittick Apparatus was first implemented by Dreimanis (1962) then modified by Machette in 1986. The method based on the volumetric evolution of carbon dioxide when carbonates react with dilute hydrochloric acid. First, samples were dried and the gravel was removed with a number 10 sieve. If the material collected on the sieve contained aggregates, the sample was disaggregated in a mortar and pestle. The remaining fine-grained material was split into small amounts to be analyzed in the Chittick, five splits of each sample were analyzed. The amount of sample was dependent on the amount of carbonate contained in the sample. For non-carbonate samples, more sediment was needed, between 1 and 2 grams. Samples containing more $\mathrm{CaCO}_{3}$ were digested by the acid much more readily so less sample was needed, between 0.75 and 1 grams (Dreimanis, 1962). An individual sample was placed into a flat-bottomed flask and connected to the Chittick apparatus, where $10 \mathrm{ml}$ of $6 \mathrm{~N}$ hydrochloric acid was added, in order to digest the carbonate. Each sample is stirred with a magnetic stir-bar under a closed system for five minutes to allow for digestion of the entire sample and equilibrium of the displacement solution to be reached. The digestion process produces $\mathrm{CO}_{2}$ gas, which displaces the solution in the Chittick. Under observed atmospheric and barometric conditions, the volume of $\mathrm{CO}_{2}$ is converted to percent of $\mathrm{CaCO}_{3}$ with use of the formula: 


\section{Equation 1}

$$
\% \mathrm{CaCO}_{3}=\frac{\left[\left(\mathrm{CO}_{\mathbf{2}} \text { volume }(\mathrm{ml})\right) \cdot\left(\frac{\text { Pressure }(\mathrm{ml})}{\text { Temperature }(\mathrm{K})}\right) \cdot(0.16)\right]}{\text { Sample Weight }(\mathrm{g})}
$$

The use of different sample sizes based on $\mathrm{CaCO}_{3}$ content increases the accuracy of the results. According to Dreimanis (1962), "the probable error of the results, which is expressed as percentages of carbonates from the total sample analyzed, does not exceed \pm 0.3 in carefully done analyses." 


\section{Appendix B: Grain size analysis, pipette methods}

The following method is based on the methods of Gee and Bauder (1986) but it is significantly modified. About 100 grams of sample was weighed out. If gravel wass present, it was removed with a $2.0 \mathrm{~mm}$ opening sieve and weighed. The rest of the sample is placed in a $600 \mathrm{ml}$ beaker and $50 \mathrm{ml}$ of the dispersant Sodium Hexametaphosphate $(50 \mathrm{~g} / \mathrm{l})$. Enough water to make a slurry was also added to the beaker. The sample was stirred in order to break up all aggregates/peds (especially if a lot of clay is present).

The slurry was then poured onto a pre-wetted \#230 seive. The sieve was placed in a large funnel inside of a large steel container to catch the sediment and water. More water was added to the sieve and aggregates were gently broken up on top of the sieve until no more sediment passes the sieve (the water runs clear). If possible, no more than $1000 \mathrm{ml}$ of water should be used. Add the "dirty" water (water plus sediment) to a hydrometer column. (If additional water was used, the extra water and sediment that does not fit into the $1000 \mathrm{ml}$ hydrometer column must be dried in an oven so the sample can be added before analysis.)

The sediment left on top of the \#230 sieve was placed in an oven. When it was completely dried, the sample was dry-seived with a \#230 seive. The passing material was added to the hydrometer column and the remaining sediment was weighed. 
The hydrometer column was filled to exactly $1000 \mathrm{ml}$ of water if not already at that level. The column was then stirred with a wooden stirring rod for five minutes or until all the sediment was in suspension. A stopwatch timer was started immediately.

Samples were collected in six labeled beakers using a $20 \mathrm{ml}$ pipette. Sample depth and time varies for a given temperature, the temperature of the lab room I used was 21 degrees Celcius and the corresponding depths and times are shown in the table below. The results were analyzed for the amount of sand, silt, and clay in each sample.

Withdrawal depths and times used for a 21 degree Celcius room.

\begin{tabular}{|c|cc|}
\hline $\begin{array}{c}\text { Withdrawal Depth } \\
\text { (cm) }\end{array}$ & $\begin{array}{c}\text { Grain Size } \\
\text { Equivalent (mm) }\end{array}$ & Time \\
\hline $\mathbf{2 0}$ & 0.063 & $0: 00: 20$ \\
\hline $\mathbf{1 0}$ & 0.031 & $0: 01: 51$ \\
\hline $\mathbf{1 0}$ & 0.016 & $0: 07: 25$ \\
\hline $\mathbf{1 0}$ & 0.008 & $0: 29: 41$ \\
\hline $\mathbf{5}$ & 0.004 & $0: 59: 23$ \\
\hline $\mathbf{5}$ & 0.002 & $3: 58: 00$ \\
\hline
\end{tabular}


Appendix C: Field Notes

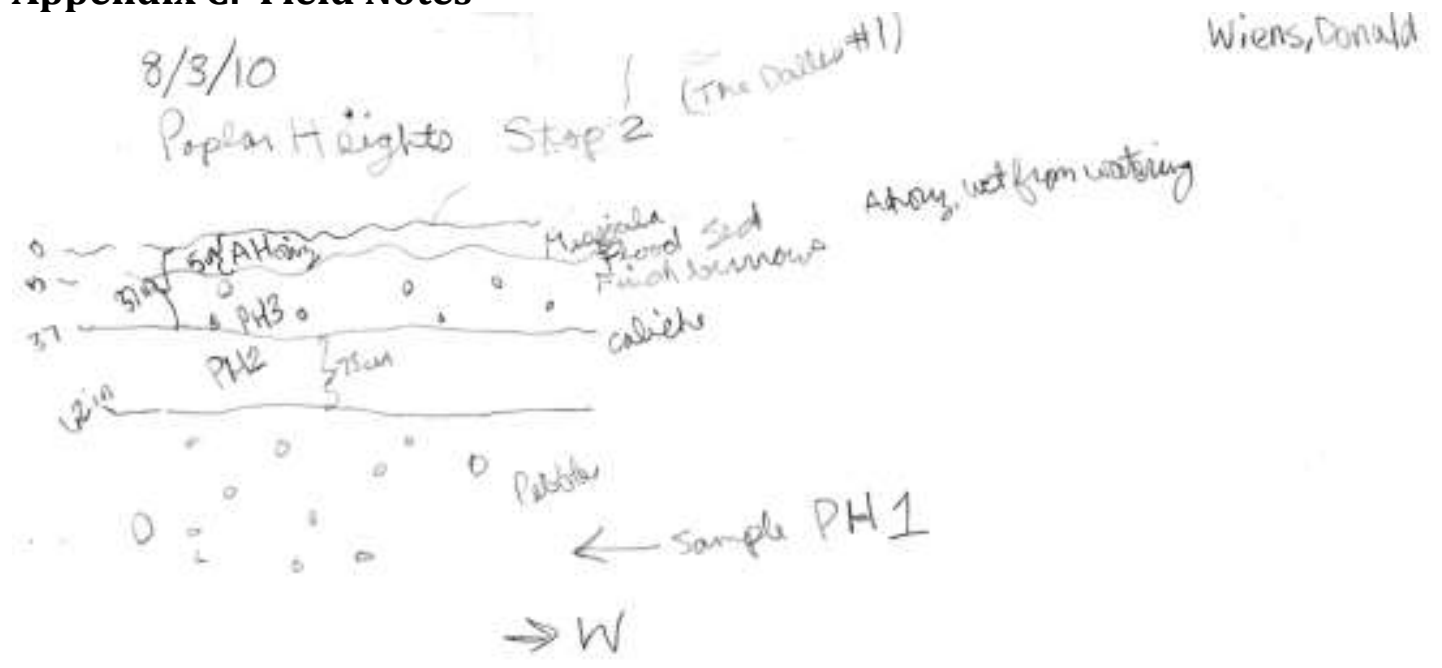

GPS arandung / to puleod

P: at $145 \mathrm{~m}$

$T: \frac{\text { der. }}{140 \mathrm{~m}} \mathrm{NTE0338005}$

$$
1511498
$$

Wouperiat 2 (waypoent 1 Thacio how is at autcrop poleasol hayes

waypoint 3 road at PH anterop

IIT E0338003

N 5114962

$245^{\text {th }}$ Avenue to 8 Oak $x$.

151 


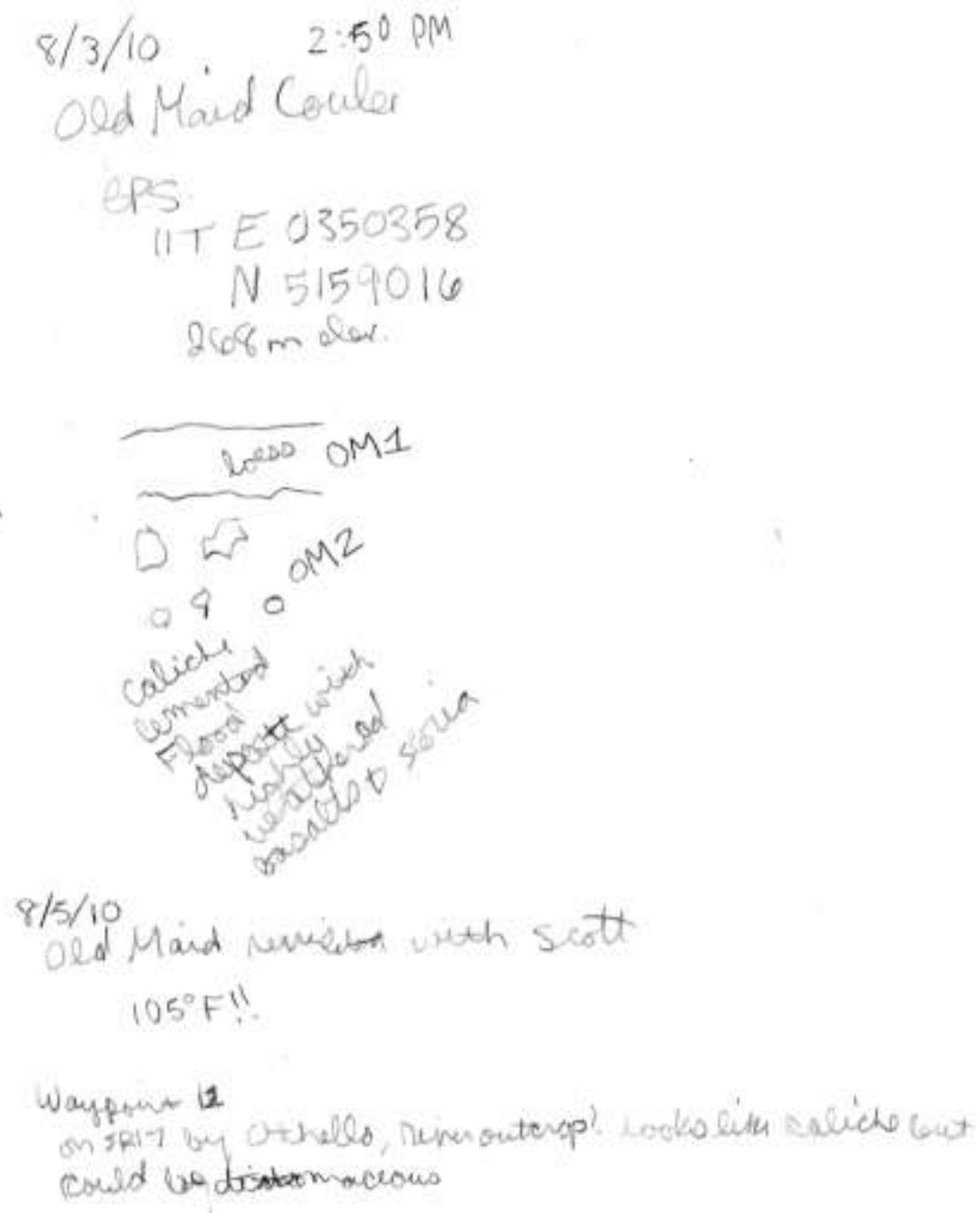

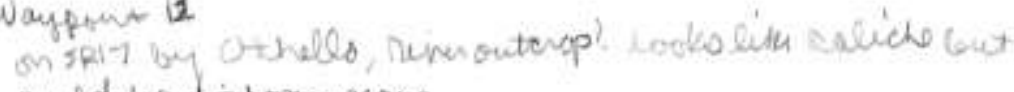
coled bo distamaceous 


$$
\begin{aligned}
& 8 / 4 / 10 \\
& \text { Pott des Coule } \\
& \text { Woyspint } 5 \\
& \text { qoev. } 386.8 \mathrm{~m} \\
& \text { IITE } 0280076 \\
& \text { N } 5227034
\end{aligned}
$$

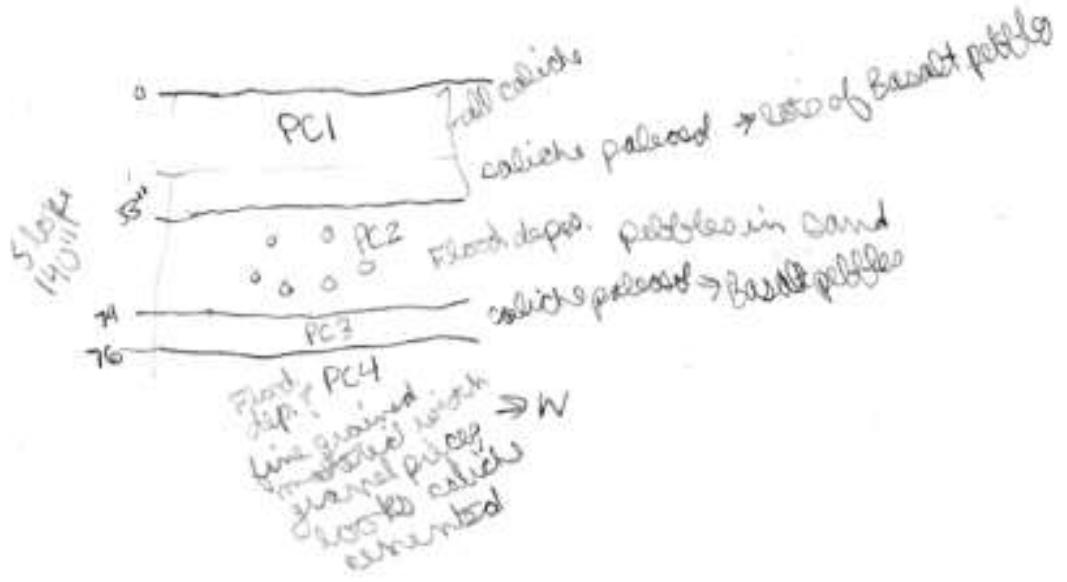




$$
\begin{aligned}
& 8 / 4 / 10 \text { Fonchmon Coulde FC } \\
& \text { Waypoint } 6 \\
& \text { Plev. } 410.2 \\
& \text { I1T E0274333 } \\
& \text { N5214201 }
\end{aligned}
$$

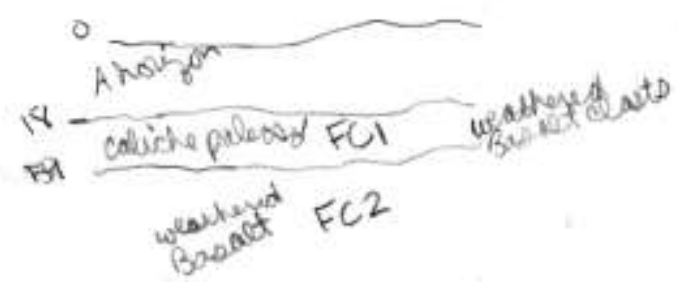

कूeे

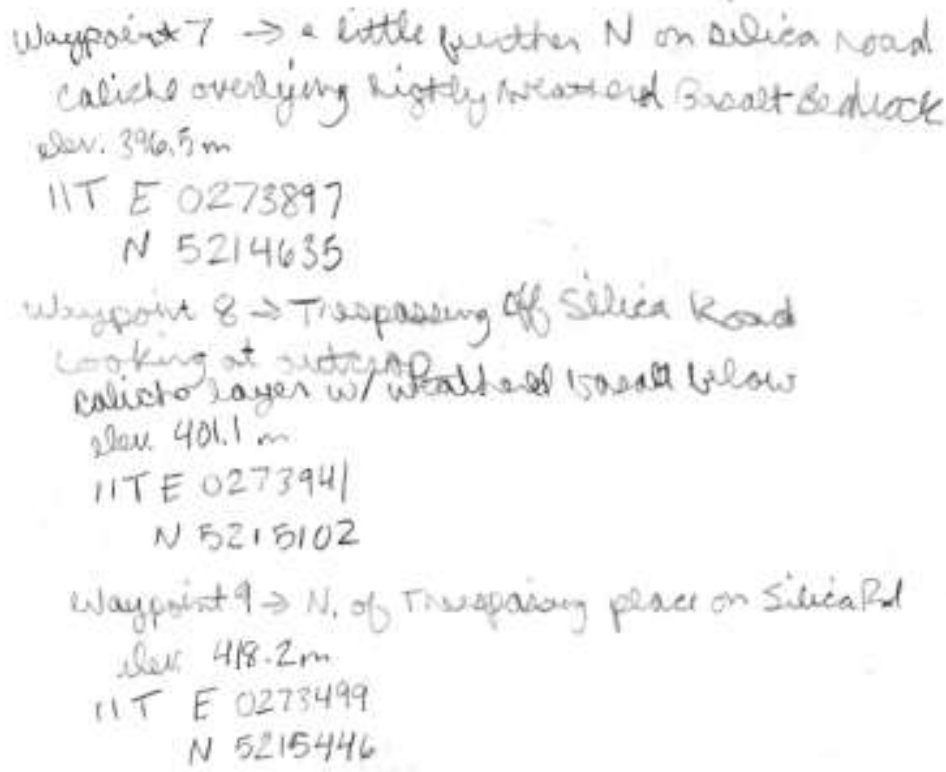


Us

N $8 / 6 / 10$

$$
2 y x^{6}
$$$$
\begin{aligned}
& \text { Rese Coulteo wompont } 13 \\
& \text { dev. } 179.6 m \text {. }
\end{aligned}
$$

(IT) 0363906

cosping in grante boulders

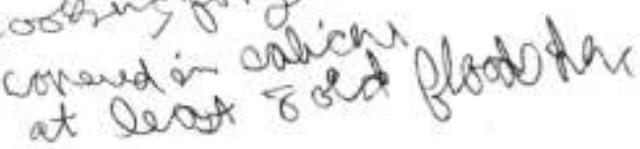
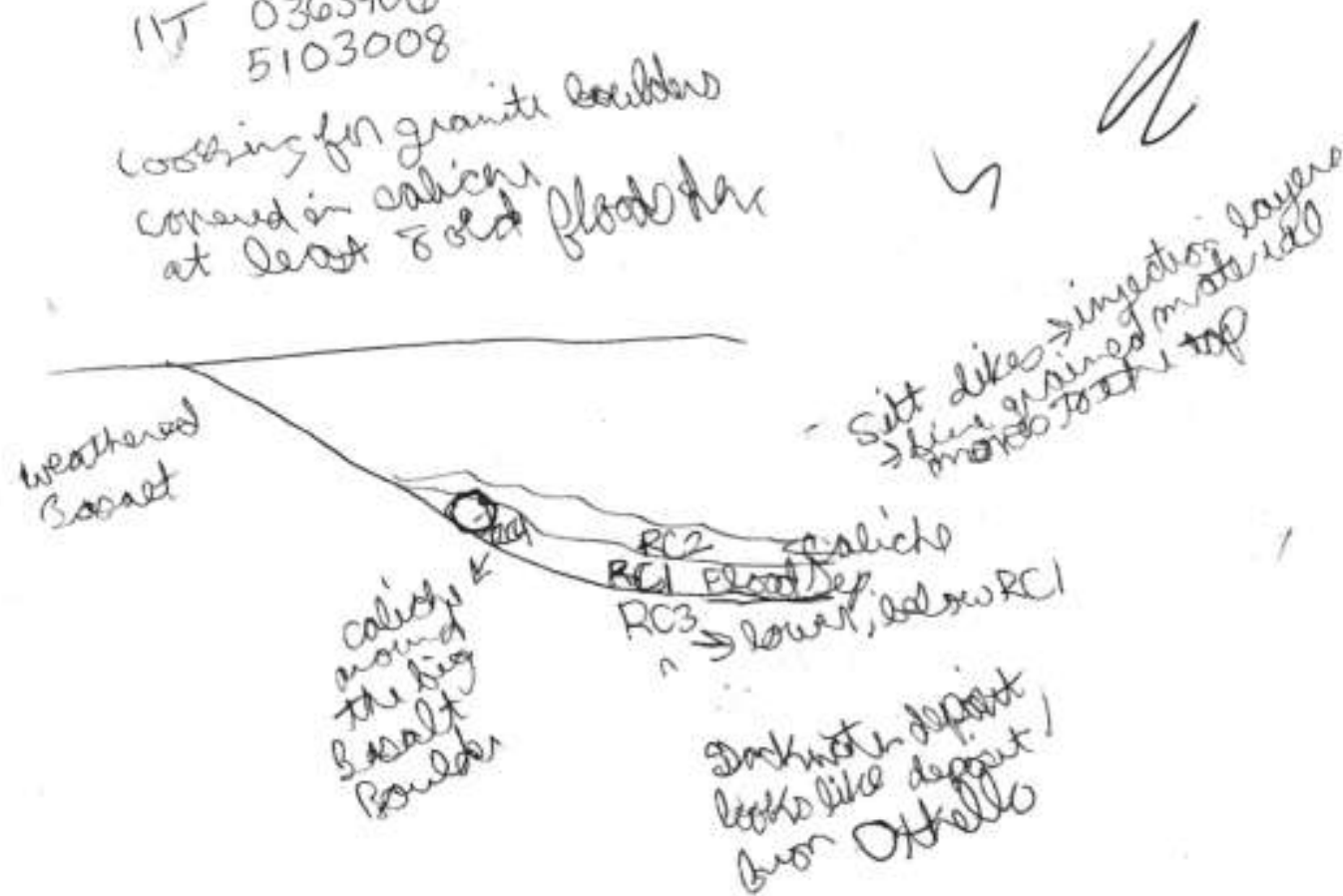

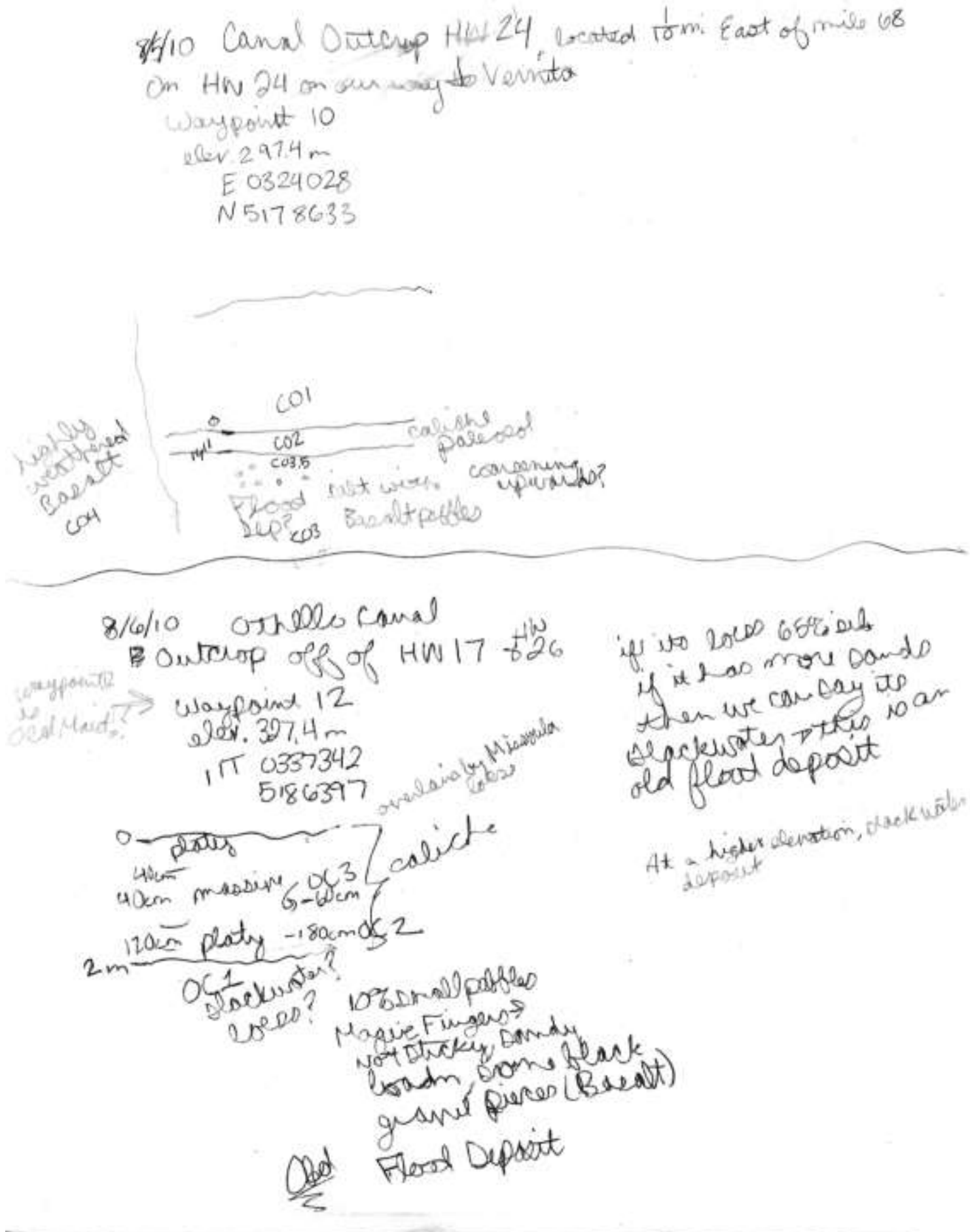


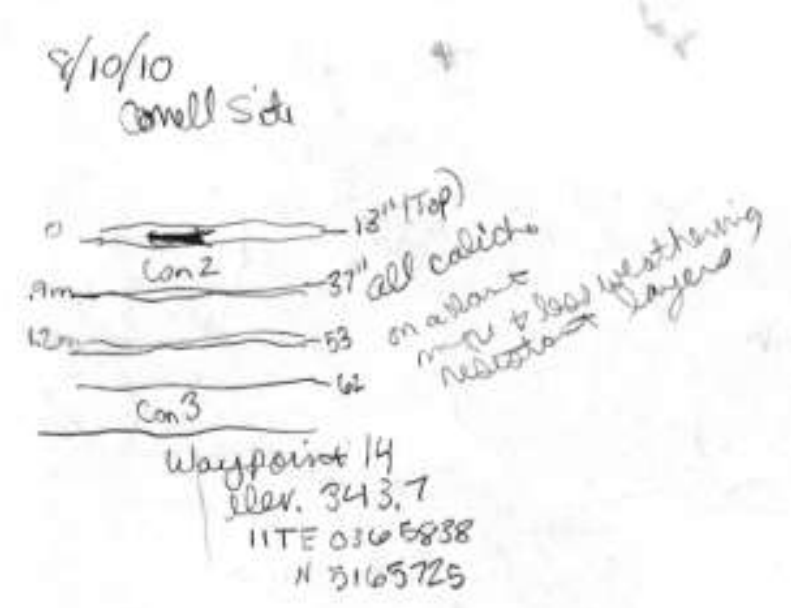

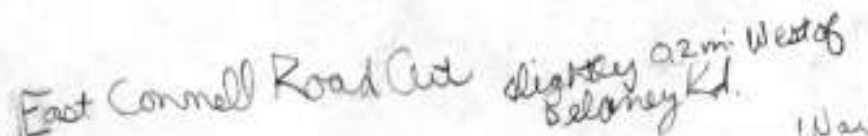
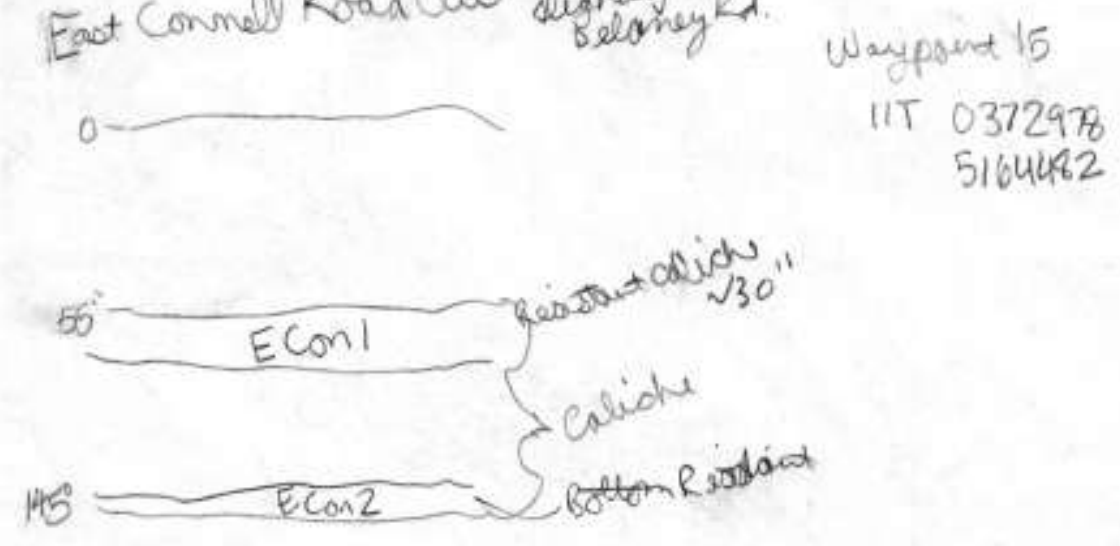

157 
8/10/2010 wasiduena, celier Coule

waypoint 16

IIT 0394470

5181904

olev 449.7
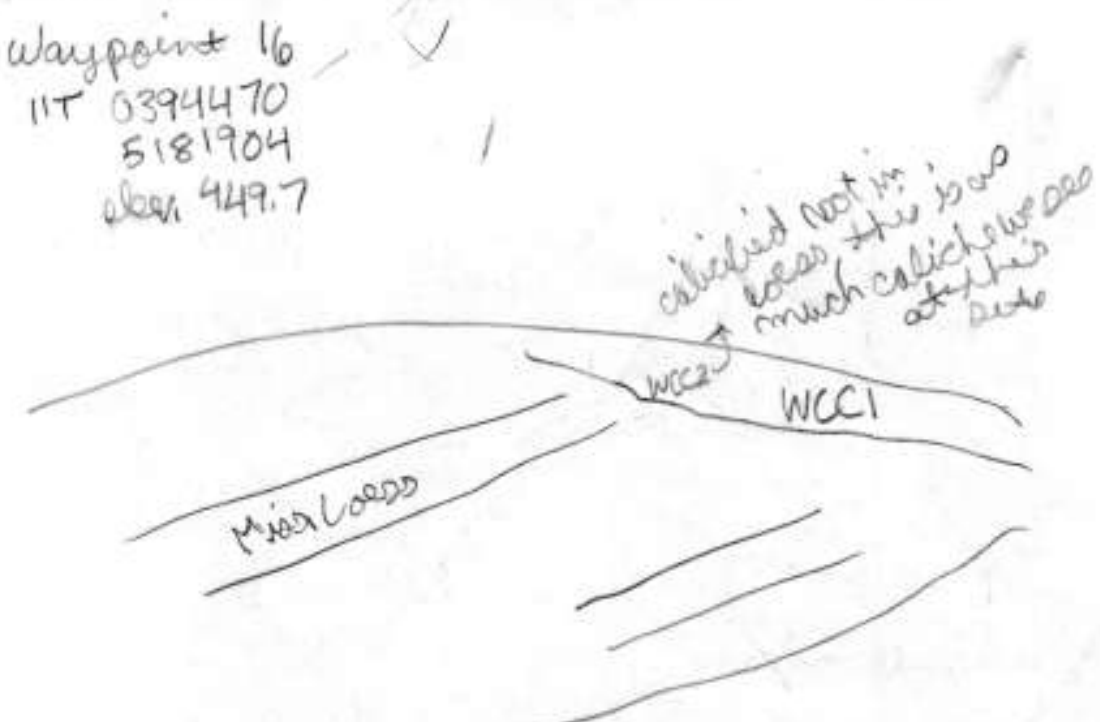

We dort see all the fabopols discused by Busacat B yoonstad

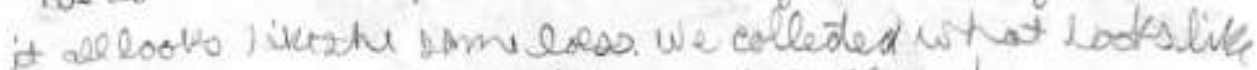
ash on the apposita side of the noad. Baffeling.

8/10/2010 0 and the woun to Palounetales SP

RonMuramakero $2700 \$ 260$

$$
\begin{aligned}
& \text { Wegpiont } 17 \\
& \text { Iler. } 452 \mathrm{~m} \\
& \text { IIT E } 0394613 \\
& N 5170269
\end{aligned}
$$

$$
\begin{aligned}
& 0.8 \text { - } \frac{P F 1}{P F 2} \text { Nownoted Basalto pumice } \\
& \text { gravely all grand }
\end{aligned}
$$




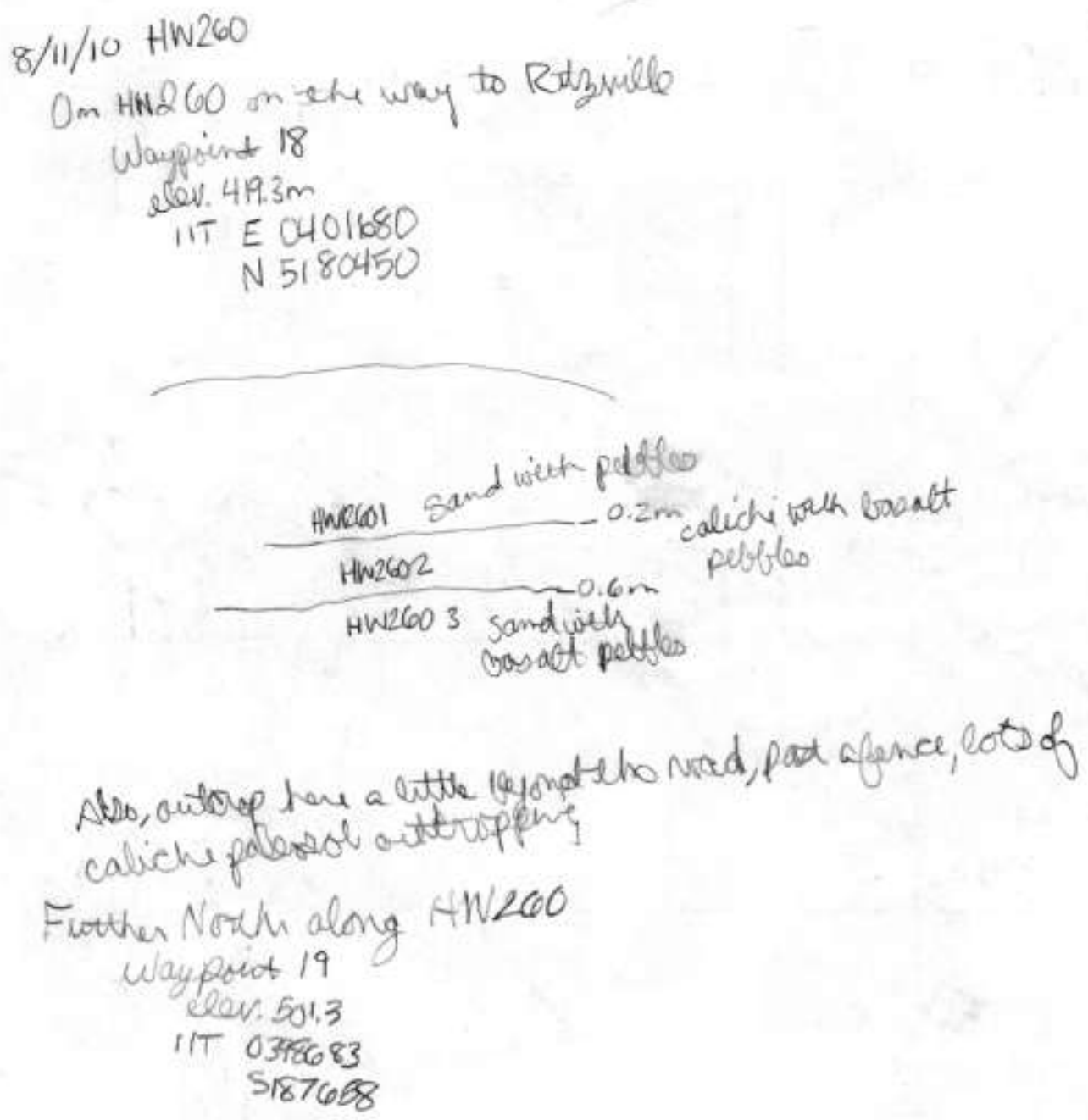

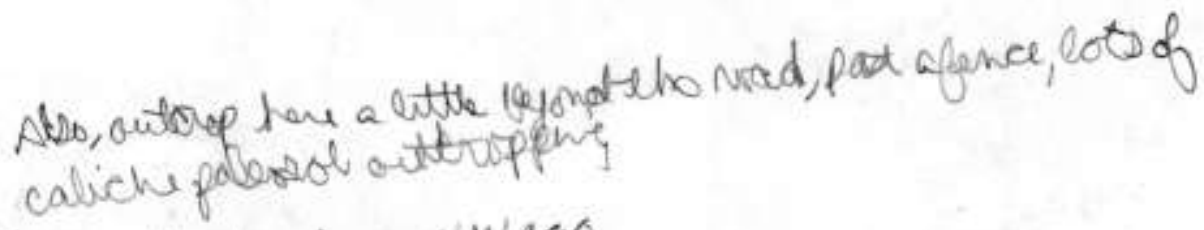

Fiother Noth along 4 N260 wayprot 19

eeer. 501,3

IIT 0398683

5187688 


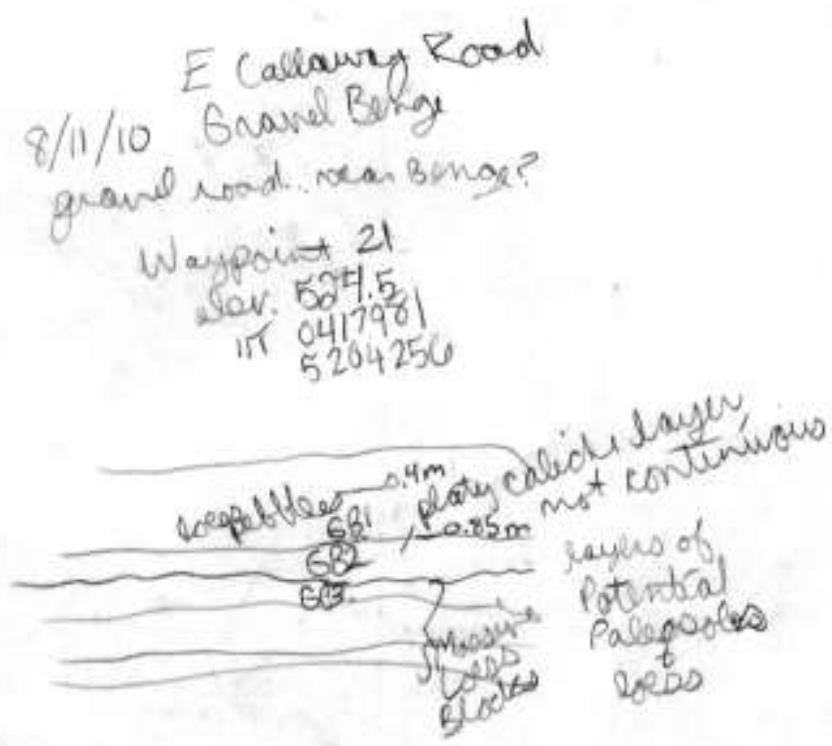




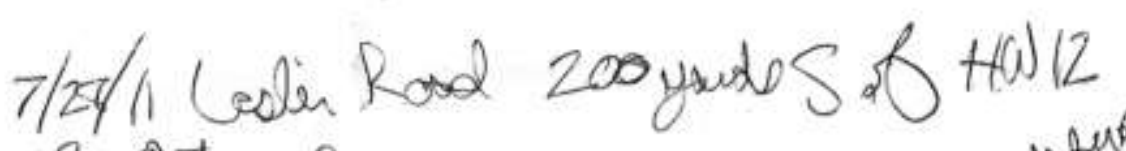
LR Orteorpwaypt

ITT 035773 3123165 $387 \mathrm{ft}$

(abs)

Cofb

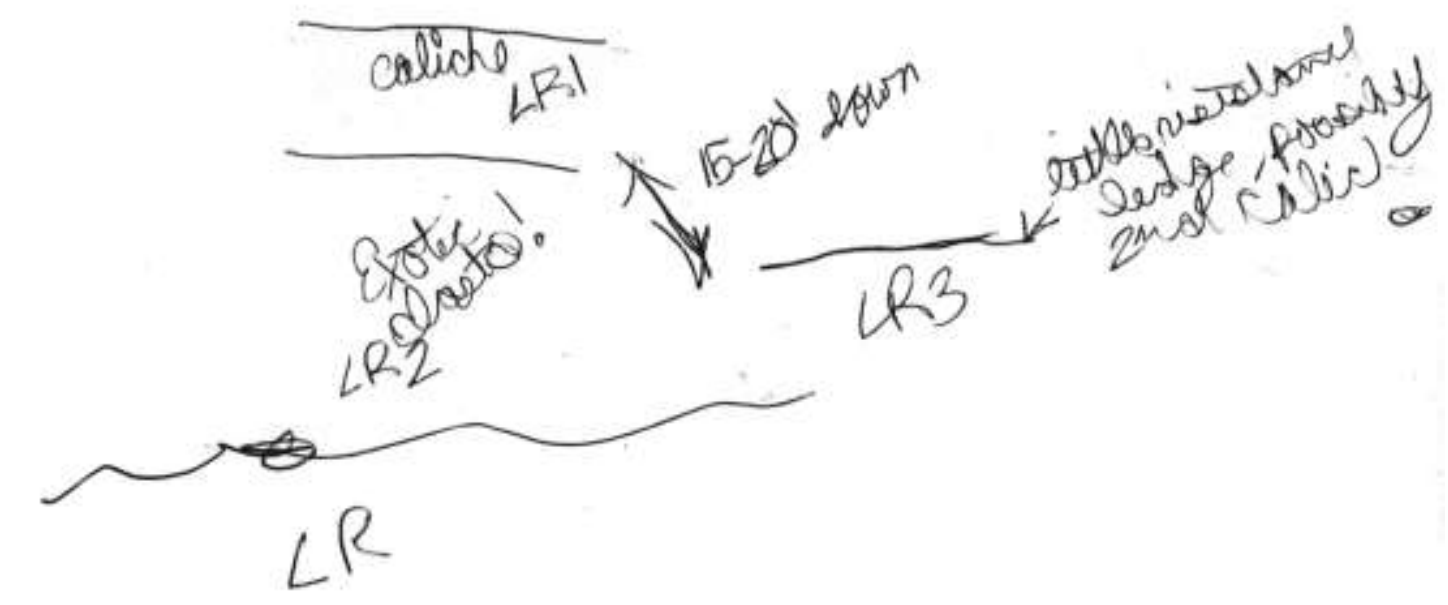

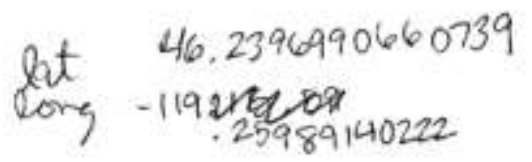

161 


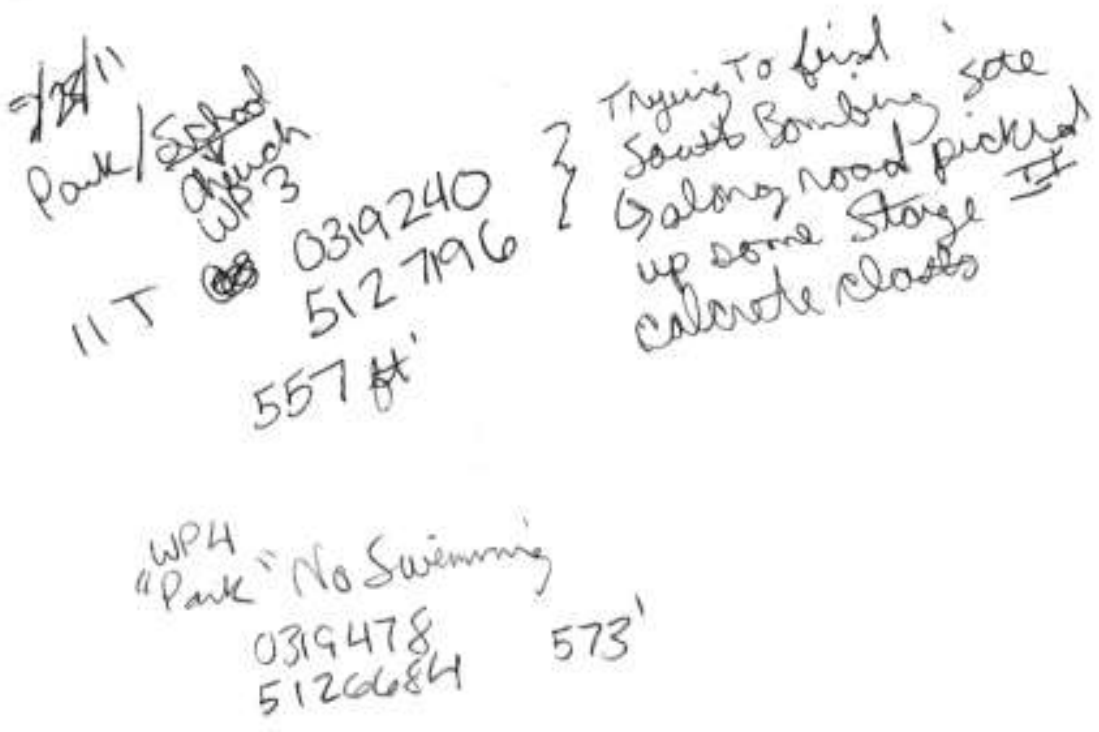

162 

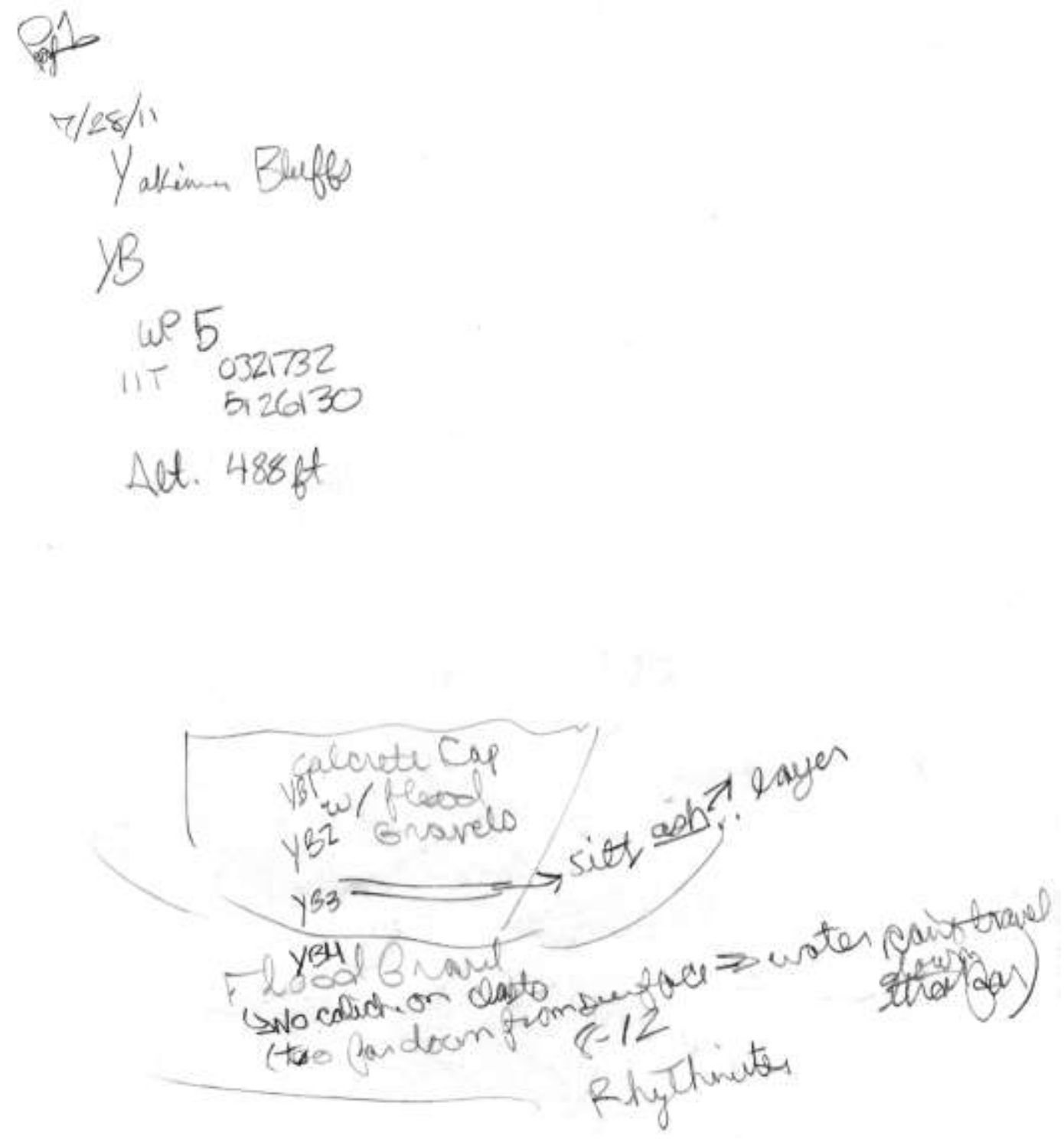
Pagez

$7 / 20 / 11$

Plochintes, Noth and of Fuman Bood notil

Ext 3 of 182 , Rt.onto Put. Aspety

tholl
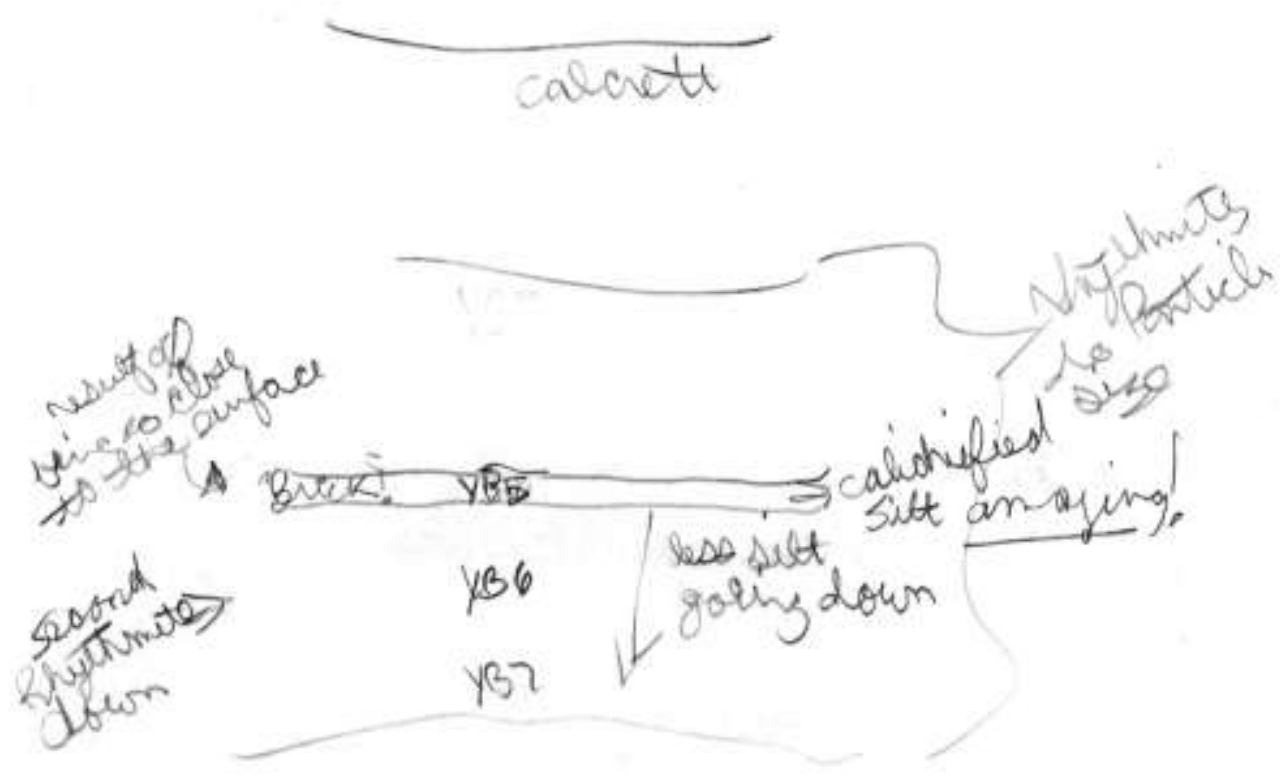

all whythutas firzs

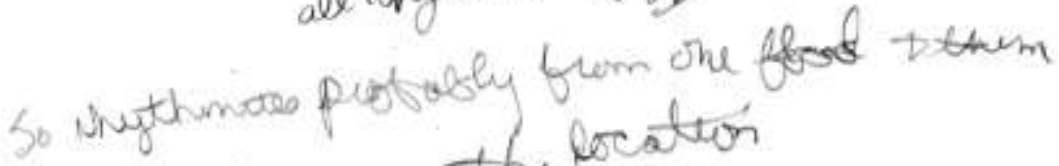
gravel fum anothe lecation

164 
$8 \times 96046$ ch (headod $N)$

$7 / 28 / 1$

$A+B$ Aoptalt "Kions Quany

onf ield fd

AJ consting + convents

$486^{\circ}$

WP 7

0310042

$512407)$

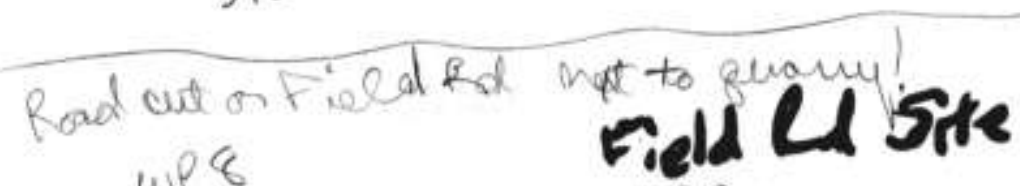
wP \&
030788
5124242 FRS

$542^{\prime}$

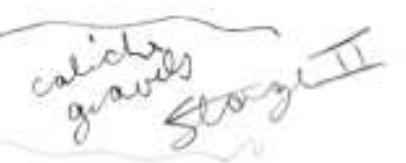

165 
$7 / 28 / 11$ Adiengton - Modern giaul stop

Mile Poot 1 on HW

$598^{\prime}$
wea
0718543
5065923

Bumple HWI 9

166 


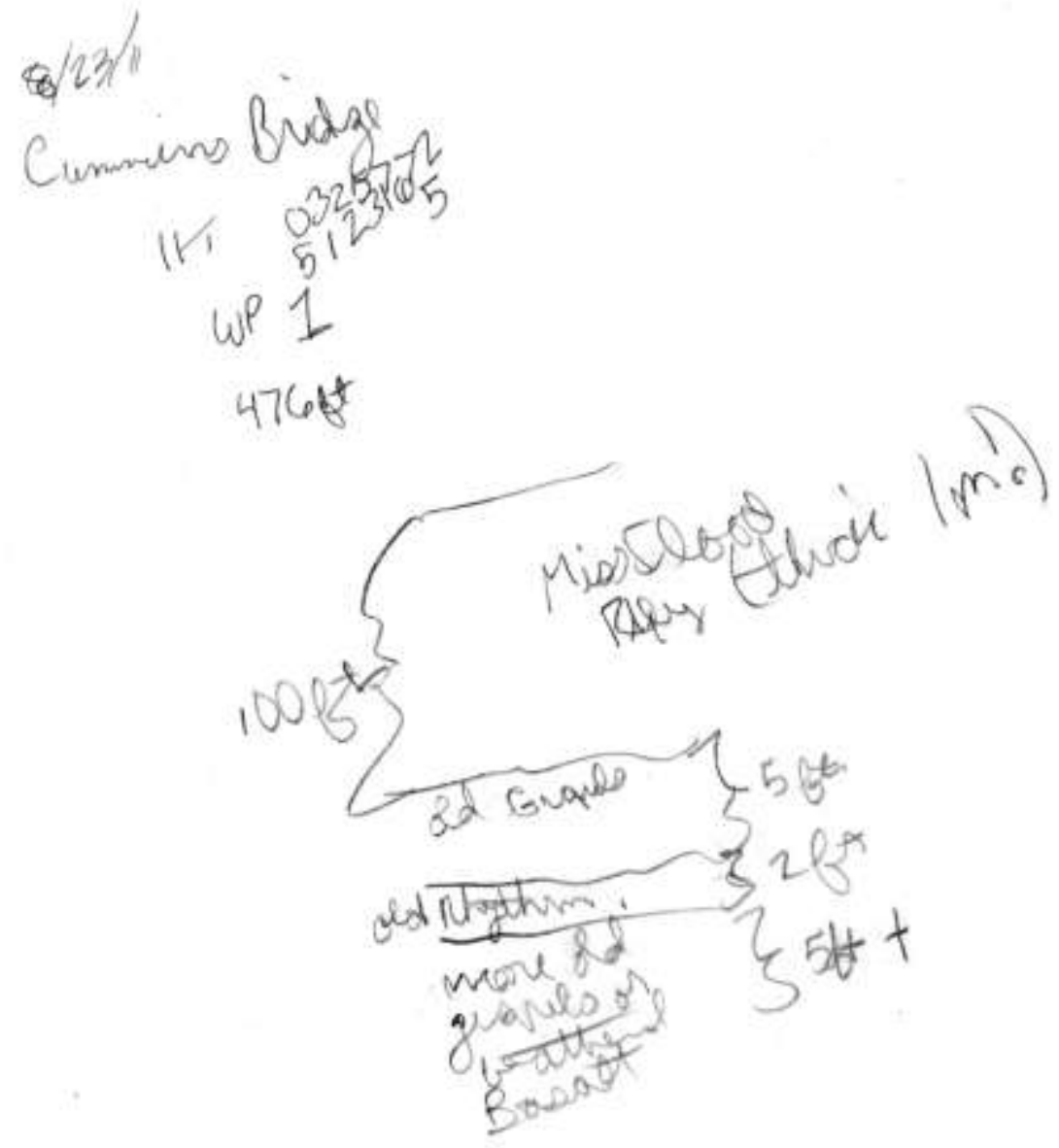




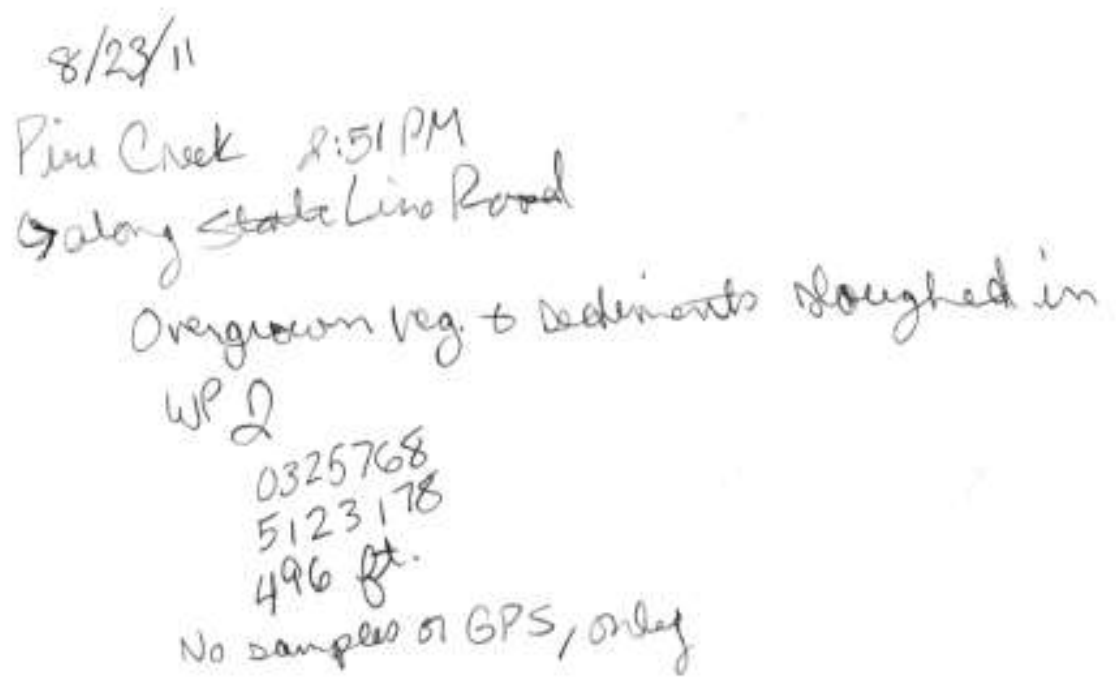

168 
$8 / 23 / 11$

$5: 13 P M$

8.7

WR1

Cocated 1.5 mi $N$ of Conely Pd on Harrey Shaw $t$.

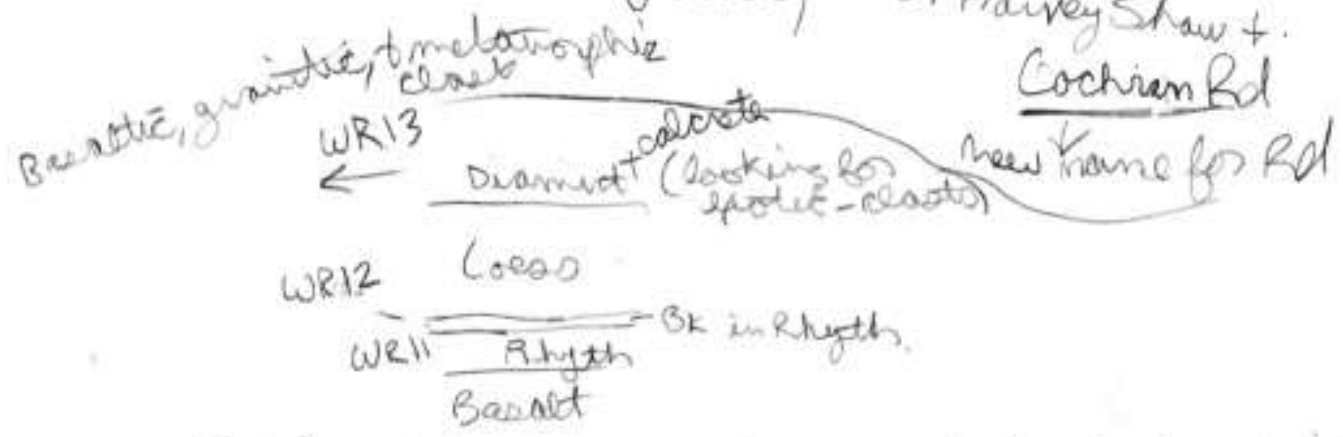

Spencers aleing these sitt-clay instead of sast sitt
lite the younge

0.4389401
5113564

$939 \mathrm{ft}$

169 


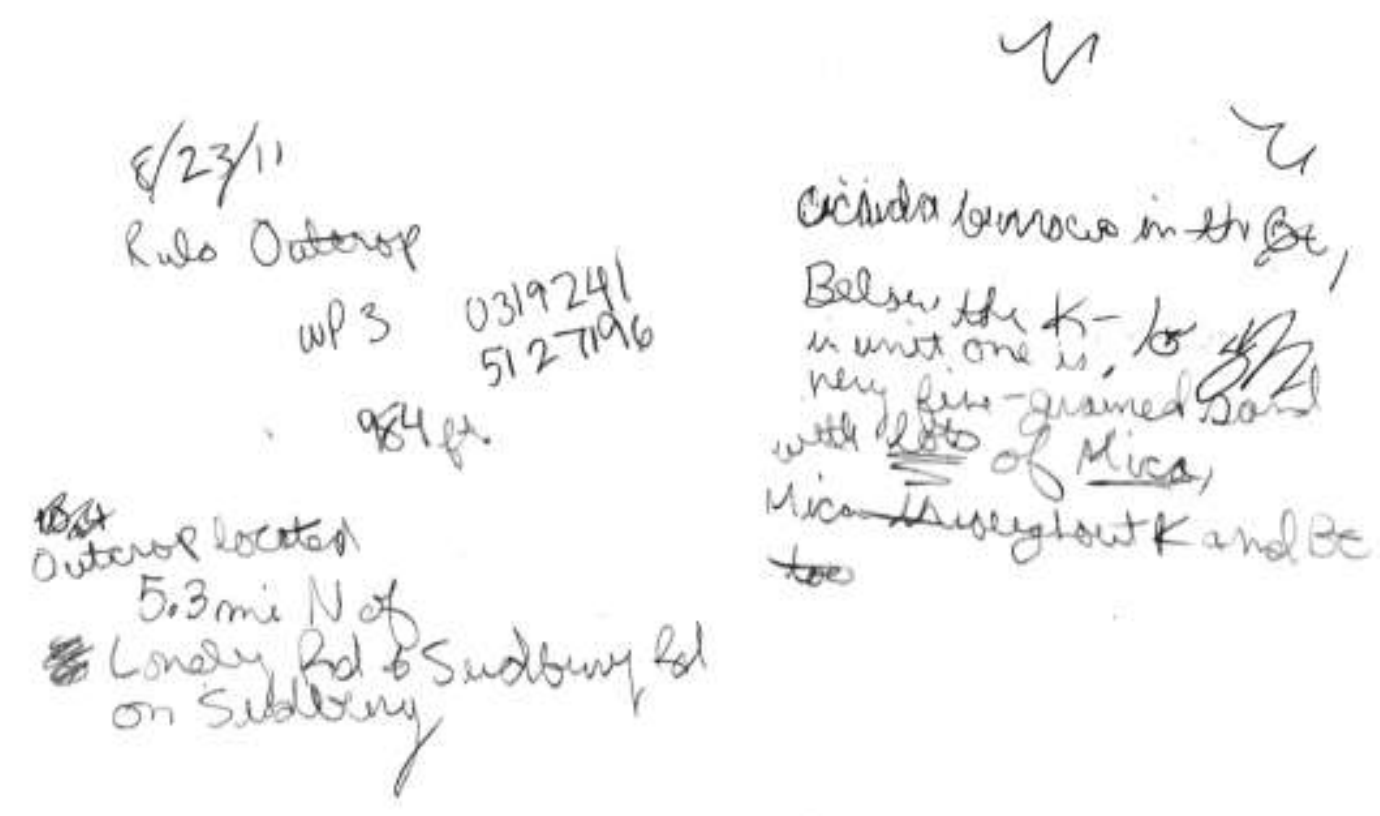




$$
\begin{aligned}
& 8 / 23 / 11 \\
& \text { WR2 }
\end{aligned}
$$

i.6 Cocated $3.0 \mathrm{mi}$ from WR1 outcrop along Coctrit Rf. 0.4 Miles west of HWl.25 Cochran WP5 $\quad \begin{array}{ll}0392636 \\ 5115929\end{array}$ $955 \mathrm{ft}^{\mathrm{t}}$

HW125 $\rightarrow$ site correlates to WR2 WP6 0394152 5121014

$9936 t$

0.2 miles $S$ of Blown Rood

$$
\begin{aligned}
& \text { Brown Road } \\
& \text { WP7 } 0394427 \\
& 5121323 \\
& 10218 t
\end{aligned}
$$

BRI sanp (lower pactofliamiot)

yifary Qoeto than dame os in pastive sizsanah.

171 
$8 / 24 / 1$ Barge

i.5. Loedeal 3.7 mi from Berge along Berge-Rolshon Rd.

$$
\begin{array}{r}
\text { upP } \\
\quad 0413066 \\
5198291 \\
1662 \text { et. }
\end{array}
$$

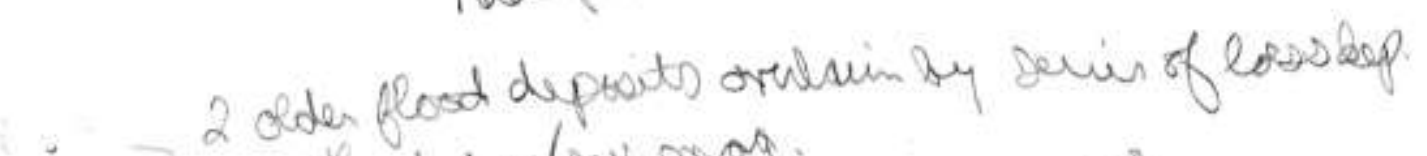

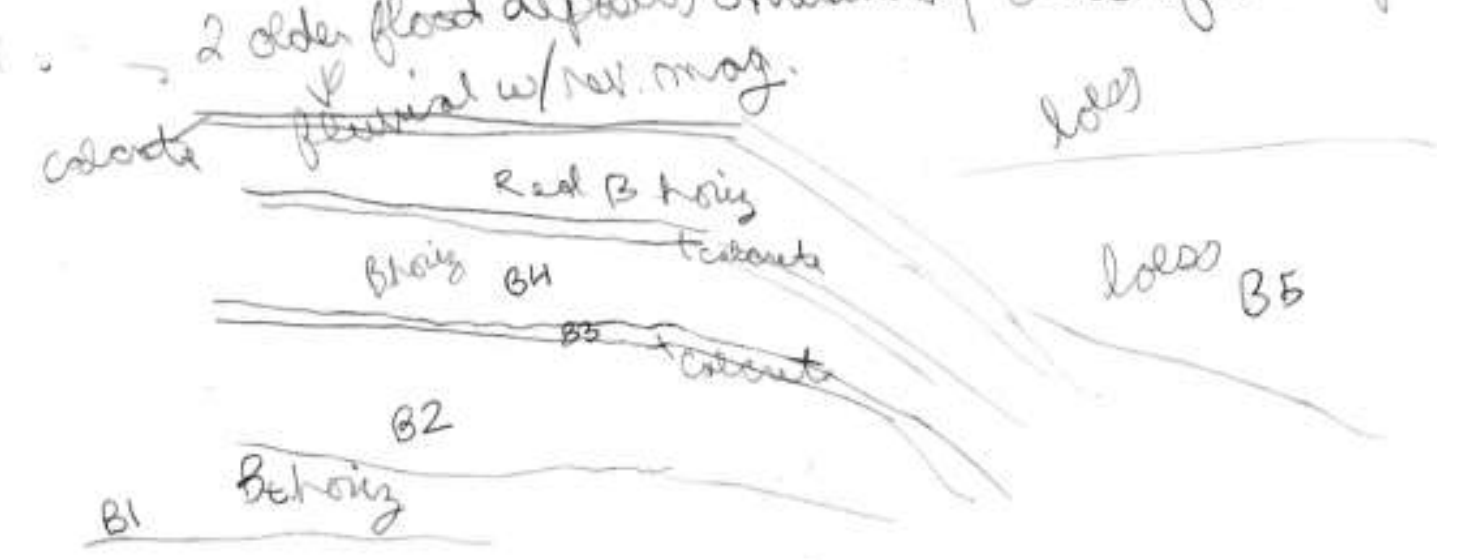

172 
8/24/1 12:0 PM

Rover

jumangatron of Cakin $R d t$ Rever, Rd. Going 3585 e coing Maillor

wPa 0428683

5215785

1664 ot.

caliche AB

$\cos s$

caliche RR

guanelo RII

oresta of of

173 


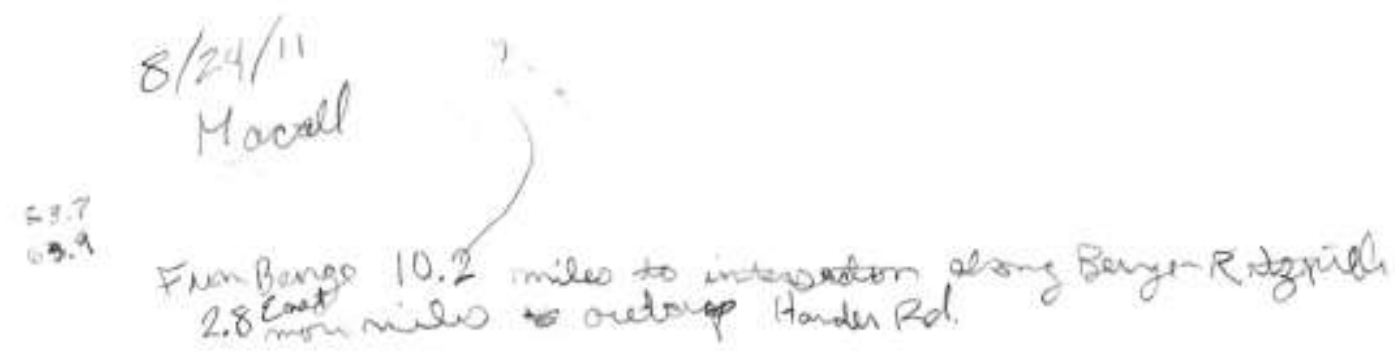

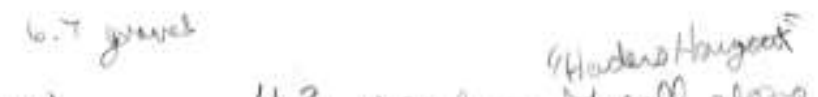

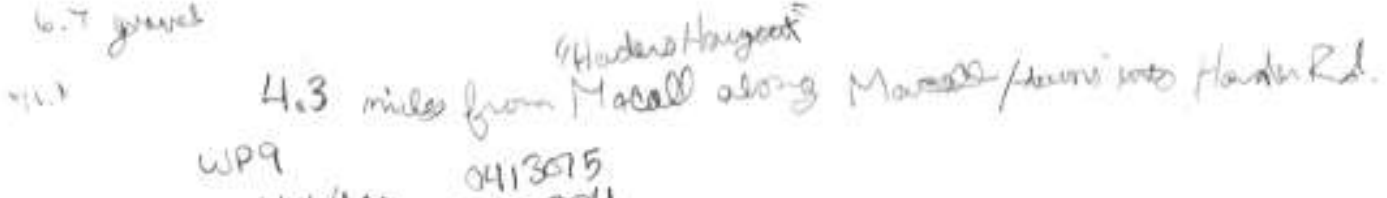

$$
\begin{aligned}
& \begin{array}{ll}
\text { wipq } & 9413075 \\
160 \mathrm{fH} & 5,98284
\end{array}
\end{aligned}
$$

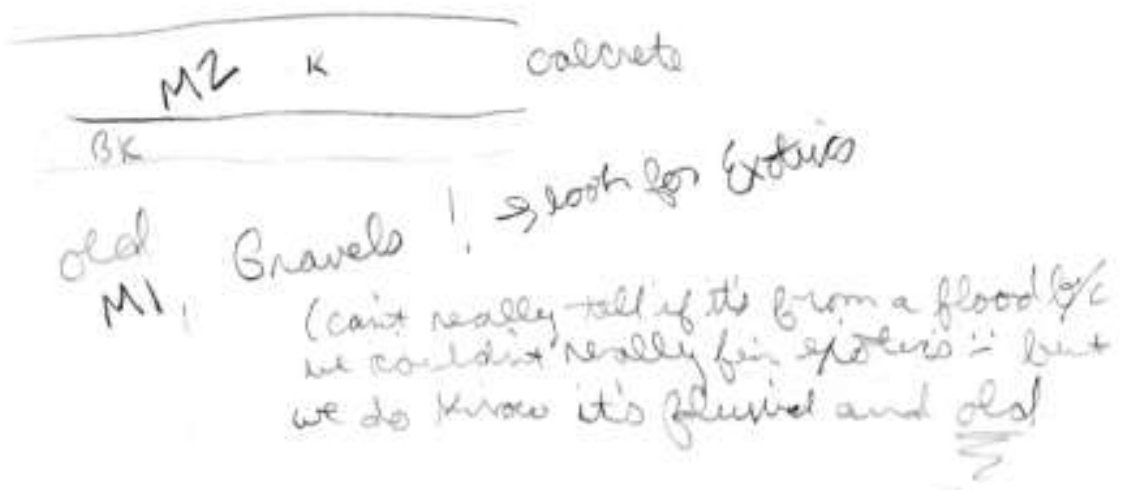

